Lake Lahontan:

Geology of Southern

Carson Desert, Nevada

GEOLOGICAL SURVEY PROFESSIONAL PAPER 401

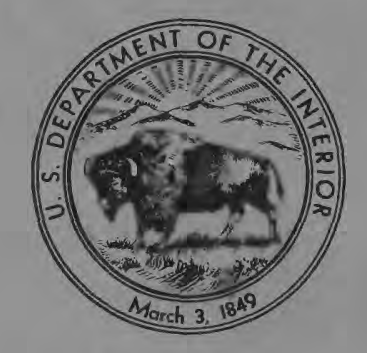




\section{Lake Lahontan:}

\section{Geology of Southern}

\section{Carson Desert, Nevada}

By R. B. MORRISON

GEOLOGICAL SURVEY PROFESSIONAL PAPER 401

A stratigraphic study of the Cenozoic geology of part of the basin of Lake Lahontan, one of the great late Pleistocene lakes of Western United States

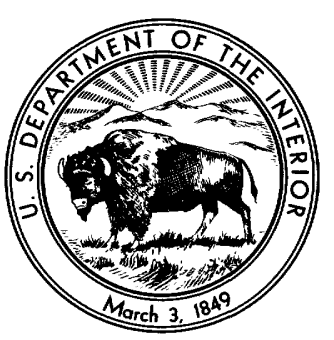




\section{UNITED STATES DEPARTMENT OF THE INTERIOR STEWART L. UDALL, Secretary \\ GEOLOGICAL SURVEY \\ Thomas B. Nolan, Director}

The U.S. Geological Survey Library has cataloged this publication as follows:

\section{Morrison, Roger Barron, 1914-}

Lake Lahontan: geology of southern Carson Desert, Nevada. Washington, U.S. Govt. Print. Off., 1963.

$\nabla, 156$ p. illus., maps, diagrs., tables. and portfolio (fold. maps (part col.) diagr., tables) $29 \mathrm{~cm}$. (U.S. Geological Survey. Professional paper 401)

Bibliography : p. 117-121.

1. Geology-Nevada-Churchill Co. 2. Geology, StratigraphicCenozoic. I. Title. II. Title: Carson Desert, Nevada. (Series) 


\section{CONTENTS}

Abstract

Introduction

Fieldwork

Acknowledgments

Previous work

Geographic setting

Major landforms

Carson Desert and adjoining basins ..........

Highlands bordering the basins.

Climate . . . . . . . .

Drainage . . . .

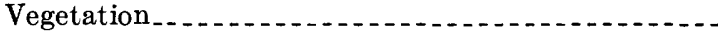

Economic geography ..............................

Tertiary stratigraphy and structure ...............

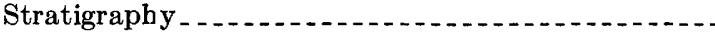

Basalt of Rainbow Mountain

Dacite of Rainbow Mountain

Eagles House rhyolite . . . . . . . . . . . . . . .

Truckee formation . .

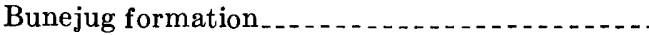

Structural features........

Pre-Truckee faults. ......................

Faults of post-Truckee and early Bunejug age..

Structural features of post-Bunejug pre-Paiute age .....

Basin-and-range faults.

General features.

Faulting in specific areas...................

Configuration of the bedrock floor of the basin . . . -

Quaternary stratigraphy.......................................

Methods of study

Stratigraphic usage

Soils _. . . . . . . . . . . . . .

Definition and general features

Soil profile.....

Classification

Descriptive terminology

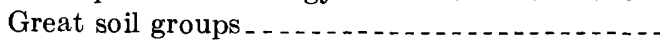

Pre-Lake Lahontan erosional features . . . . . . . . . .

Pre-Lake Lahontan Quaternary stratigraphy .......

Basalt of Ratilesnake Hill . . . . . . . . . . . . .

Pre-Lake Lahontan lacustrine sediments.......

Paiute formation

Buried pre-Lake Lahontan Quaternary sediments . . .

Cocoon soil .

General features and relations.........

Profile characteristics

Age

Lahontan Valley group.

Eetza formation

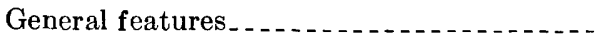

Lake gravel. .

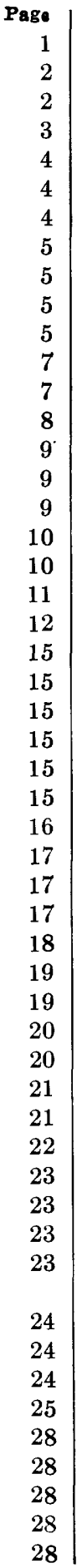

Quaternary stratigraphy-Continued

Lahontan Valley group-Continued

Eetza formation-Continued

Shore features

Tufa ............ 31

Intra-Eetza lake recession.............. 31

Lake sand, silt, and clay................ 33

Correlation with deposits of Lake Lahontan described by Russell and Antevs........ 33

Paleontology .............. 33

Alluvial gravel and colluvium of Eetza age..... 33

Wyemaha formation . ................... 34

General features............ 34

Correlation with deposits of Lake Lahontan described by Russell and Antevs.........

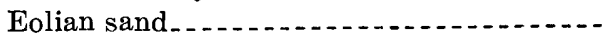

Alluvial and colluvial gravel and sand.-.-.

Interbedded shallow-lake and subaerial

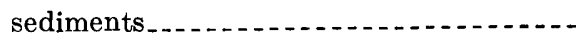

Subsurface basin sediments... . . . . . . .

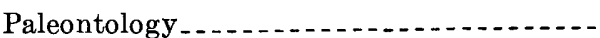

Basaltic tuff of Upsal Hogback ..........

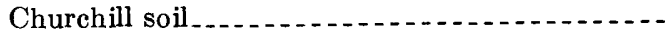

General relations and distribution.......

Profile characteristics . . . . . . . . . . . . . . .

Sehoo formation. .......

General features..............

Members. . . .

Lower member ......................

Thinolite unit.....

Dendritic member. . . .

Upper member. ...................

Shore features of Sehoo age.......

Shorelines of the early Sehoo lake..........

Comparative heights of highest Eetza and early Sehoo shorelines at Russel Spit ...-

Lake levels during deposition of the thinolite unit . . . . . . . . . . . . .

Shorelines of the middle Sehoo lake; "dentritic terrace".

Shorelines of the late Sehoo lake

Indian Lakes formation..............

General features. ......................

Tongues and age units

Alluvium and colluvium above the Lahontan beach...............

Lower tongue . . . . . . . . . . . . .

Middle tongue......................

Alluvium of middle Sehoo and Indian Lakes age..........................

Alluvium, colluvium, and eolian sand of late Sehoo and Indian Lakes age.-

Volcanic-sand complex of Soda Lake 
Quaternary stratigraphy-Continued

Lahontan Valley group-Continued

Fossils of Sehoo and Indian Lakes age.......

Soils of Sehoo and Indian Lakes age............ Incipient unnamed soil of middle Indian

Lakes age.................................

Harmon School soil ...................

Turupah formation . . . . . . . . . . . . . . . .

General features. . . . . . . . . . . . . . . .

Eolian sand . . . . . . . .

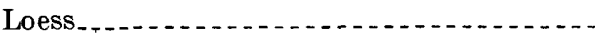

Alluvial sand .........................

Disconformity coeval with the Turupah formation; evidence of complete lake desiccation ........................

Fossils

Toyeh soil ......

Stratigraphic relations and occurrence......

Profile characteristics....................

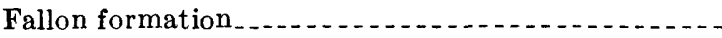

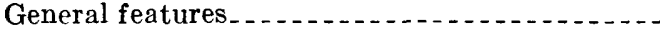

Lower member . . . . . . . . . . . . . . . . . . . .

Upper member . . . . . . .

Lake and interlake units..................

Eolian sand . . . . . .

Alluvium . . . . . . . .

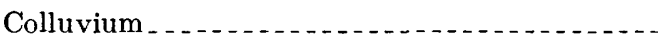

Lake sediments and shore features.......... Fossils

Soils of Fallon age

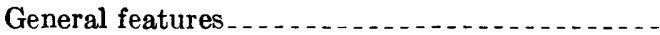

L-Drain soil............

Soil of late Fallon age . . . . . . . . . . . . . .

Structural features of Lahontan Valley and Fallon age...

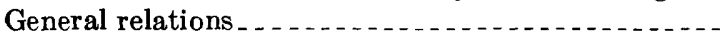

Pre-Sehoo faults

Post-Sehoo faults........

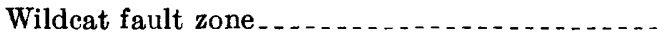

Other marginal faults . . . . . . . . .

Sagouspe fault zone

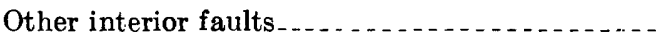

Displacement of shorelines

Possible explosion craters of late Fallon age near Stillwater Lakes

Earthquakes in historic time.

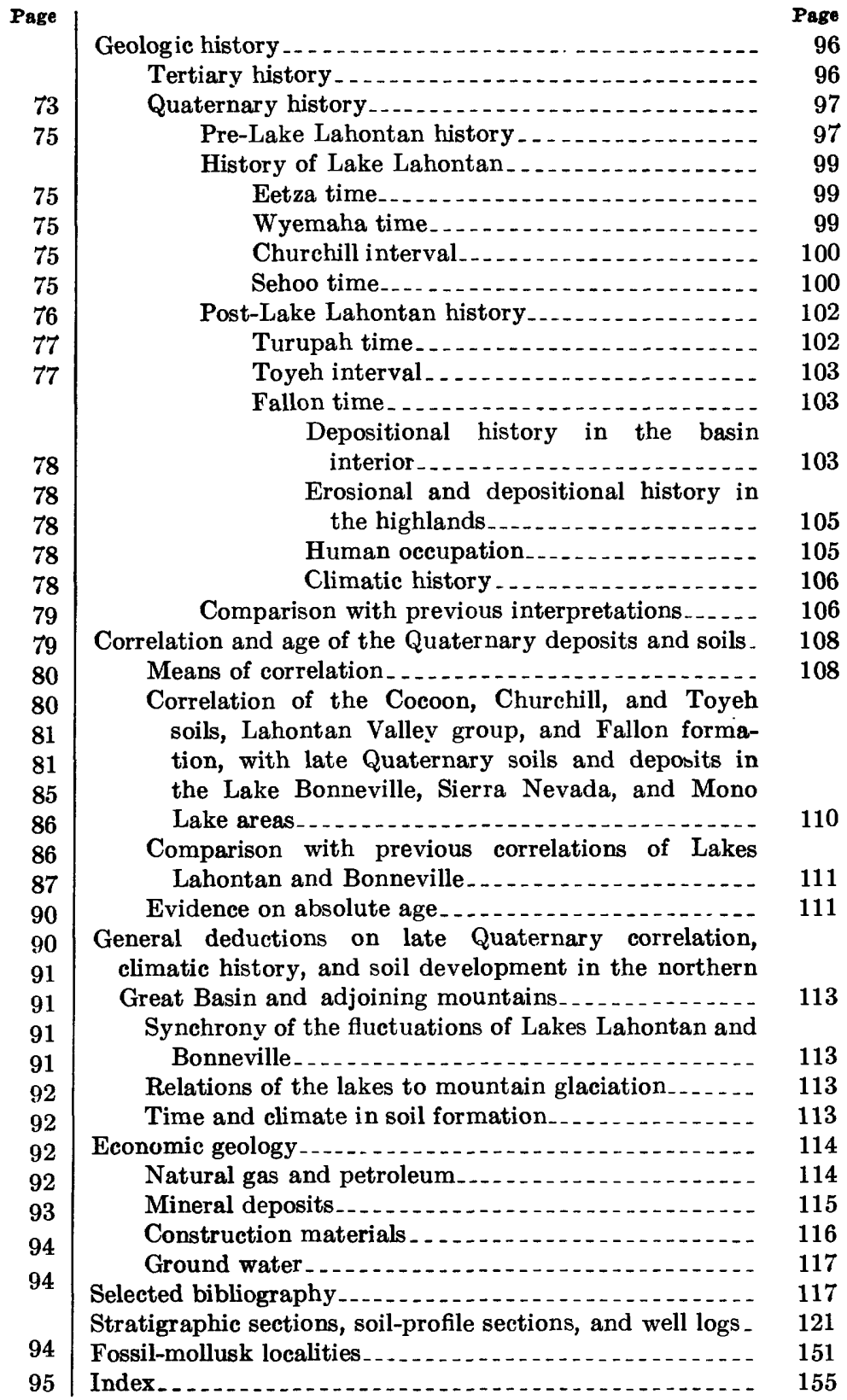

\section{ILLUSTRATIONS}

[Plates are in separate volume]

Plate 1. Shaded relief map of the Carson Desert area.

2. Topographic map of the southern Carson Desert area.

3. Geologic map of the Carson Lake quadrangle, Nevada.

4. Geologic map of the Stillwater quadrangle, Nevada.

5. Geologic map of the Fallon quadrangle, Nevada.

6. Geologic map of the eastern Soda Lake quadrangle, Nevada.

7. Geologic map of saddle at western end of Wyemaha Valley.

8. Cross section, western Wyemaha Valley.

9. Altitudes and time relations of shorelines in the Carson Lake quadrangle.

10. Relative times of soil formation and tufa deposition.

11. Map of Carson River channels and highest lake levels of Fallon time.

12. Correlation of the late Quaternary successions of the Lake Lahontan, Lake Bonneville, and Sierra Nevada areas. 
FIGURE 1. Map showing location of report area and area inundated by Lake Lahontan.

2. Diagram of topographic and geologic positions of principal plant associations

3. Exposures of Bunejug and Truckee formations in White Throne Mountains-

4. Diagram showing age and stratigraphic relations of the five main (named) late Quaternary soils in the Carson Desert area . .

5. Section through basin of Paiute Wash.

6. Cocoon soil. $A$, At type locality; $B$, on sloping surfaces

7. Northern piedmont of Desert Mountains.

8. Gravel of Eetza formation

9. Compound high-level bar near Russell Spit.

10. Aerial photograph of western Lahontan Mountains . . .

11. Aerial views. $A$, High-level spits at southwest edge of Carson Desert; $B$, compound low-level spit. . . . . . .

12. Occurrences of the Wyemaha formation . .

13. Type locality for Churchill soil and lower member of Sehoo formation and lower tongue of Indian Lakes formation.

14. Churchill soil on alluvial gravel of the Wyemaha formation .

15. Eetza, Wyemaha, Sehoo, and Indian Lakes formations

16. Lithoid tufa of the lower member of the Sehoo formation

17. Lithoid and "coralline" tufa of the lower member of the Sehoo formation

18. Cellular tufa and thinolite.

19. "Heads" of dendritic tufa

20. Dendritic tufa showing internal structure

21. Blanket deposits of dendritic tufa at Eetza Mountain

22. Specimen showing texture of tufa "branches" and specimen showing tufa "heads" resting on late thinolite

23. Early and late lithoid tufa of the upper member of the Sehoo formation

24. Lithoid tufa of the first and third lake units of the Fallon formation

25. Geologic map of spit southwest of Bunejug Mountains

26. Comparative columnar sections of clay of the lower Sehoo

27. Diagrammatic cross section showing occurrence of thinolite

28. Hachure map of Russell Spit and vicinity

29. Geologic map of Russell Spit and vicinity

30. Sand and clay of the upper member of the Sehoo and Toyeh soil

31. Diagrammatic cross section showing relations of the Fallon, Turupah, Sehoo, and Wyemaha formations.......

32. Fallon formation disconformable upon Sehoo formation

33. Geologic map of the type locality of two units of the Fallon formation

34. Geologic map showing relations of various units of the Fallon formation along a portion of Wildcat scarp......

35. L Drain soil

36. Section through southwestern part of Sagouspe fault zone

37. Earthquake cracks

38. Comparison of various interpretations of Lake Lahontan history

39. Radiocarbon dates from the Lake Lahontan area

\section{TABLES}

TABLE 1. Climatic data at Fallon, Churchill County, Nev

2. Climatic data at Lahontan Dam, Churchill County, Nev

3. Major Cenozoic rock-stratigraphic units in the southern Carson Desert area

4. Principal differences in gravel units of the Sehoo formation

5. Tufas of the Eetza, Sehoo, and Fallon formations

6. Mollusks in the Eetza, Sehoo, and Fallon formations.

7. Subdivisions of the Fallon formation

8. Combustion (Orsat type) analyses of natural gas from two wells near Stillwater, Nev

9. Analysis of natural gas from two wells 9 miles south of Fallon

10. Stratigraphic sections in the southern Carson Desert area

11. Soil-profile sections in the southern Carson Desert area

12. Logs of wells in the southern Carson Desert area 



\title{
LAKE LAHONTAN: GEOLOGY OF SOUTHERN GARSON DESERT, NEVADA
}

\author{
By R. B. MORrison
}

\begin{abstract}
This report presents a stratigraphic study of an area of about 860 square miles in the southern part of the Carson Desert, near Fallon, Churchill County, Nev. The exposed rocks and surficial sediments range in age from early Tertiary(?) to Recent. The late Quaternary sediments and soils were especially studied: they furnish a detailed history of the fluctuations of Lake Lahontan (a huge but intermittent late Pleistocene lake) and of younger lakes, as well as a history of late Quaternary sedimentation, erosion, soil development, and climatic change that probably is representative of the northern part of the Great Basin.

The Tertiary rocks are divided into five main map units The lower three are chiefly lavas : the Miocene or older andesite of Rainbow Mountain and dacite of Rainbow Mountain, and the Eagles House rhyolite of Miocene to Pliocene age. The Truckee formation, which overlies these, consists of tuff, tuffacious sandstone, gravel, diatomite, and limestone, and contains lower Pliocene fossils. The youngest and most extensively exposed unit, the Bunejug formation, is mainly andesitic and basaltic lavas of Pliocene and possibly early Pleistocene age. Generally it overlies the Truckee formation with an angular unconformity, but in the south its lower part may intertongue with the Truckee formation.
\end{abstract}

All the Tertiary rocks are cut by high-angle normal faults, and commonly are more or less tilted. The degree of deformation increases with age of the rocks, showing that faulting was fairly continuous. The earlier Tertiary deformations were mostly compressional, with notable strike-slip faulting, but Quaternary faulting was dominantly tensional. Few of the older faults are exposed; most exposed faults date from two climaxes: the first in late Pliocene or early Quaternary time, and the second probably also in relatively early Quaternary time-long before Lake Lahontan time. During the interval of relative quiescence between these two elimaxes, extensive pediments formed at the edges of the mountains. The main faults were active repeatedly, and as most of them bounded mountain blocks, relief was increased progressively to a maximum at the close of the second climax. Subsequent erosion and sedimentation have been more rapid than faulting and have progressively lowered the mountains and filled the basins.

The Carson Desert, long a major drainage sump of the northwestern Great Basin, contains Quaternary sediment probably more than 1,000 feet thick in places. It is one of the largest and deepest basins of northern Nevada inundated by Lake Lahontan; its fioor lies as much as $\mathbf{5 1 5}$ feet below the highest shoreline. The area mapped covers the whole range of lake fluctuations from highest to complete desiccation. The exposed Quaternary deposits, exclusive of volcanics, comprise seven main units which are, from oldest to youngest: (1) lacustrine sediunents of pre-Lake Lahontan age; (2) subaerial sediments and soil of late pre-Lake Lahontan age; (3) deep-lake sediments and minor amounts of intertonguing subaerial deposits of early Lake Lahontan age; (4) subaerial sediments, soil, and intertonguing shallow-lake sediments of middle Lake Lahontan age ; (5) deep-lake sediments and minor amounts of intertonguing subaerial deposits of late Lake Lahontan age; (6) subaerial sediments and soil of early post-Lake Lahontan age; and (7) subaerial sediments and intertonguing shallow-lake sediments of late post-Lake Lahontan age. Only the deposits of Lake Lahontan and younger age are widely exposed.

Pre-Lake Lahontan history is fragmentary, but Lake Lahontan and post-Lake Lahontan history is fairly complete. A lake older than Lake Lahontan is suggested by a single exposure of lacustrine sediment. After deposition of this sediment, a long interval of lake recession or desiccation ensued, during which all lakes remained at least 420 feet below the maximum level of Lake Lahontan. During early Lake Lahontan time the lake reached its maximum level of 4,380 feet, receded briefly to at least as low as 4,100 feet, then rose again to 4,340 feet. In middle-Lake Lahontan time the basin intermittently was dry and held shallow lakes. During late Lake Lahontan time the lake had 3 maximums and 2 recessions; first it rose to 4,370 feet, then dropped to at least 3,990 feet, then rose to 4,190 feet, then dropped at least to 3,900 feet, and then rose a last time to 3,990 feet. During early post-Lake Lahontan time the basin generally was completely dry, and during late post-Lake Lahontan time five successive small lakes, having maximum depths of 15 to 85 feet, occupied parts of the basin floor.

The writer's deductions on the lake history give no support to J. C. Jones' (1925) interpretation of a single lake cycle starting a mere 2,000 year or so ago. These deductions agree, however, with most of Russell's (1885) and Antevs' (1945, 1948, 1952 ) conclusions. The writer's belief that Lake Lahontan had multiple maximums during both early and late Lake Lahontan times supplements both Russell's and Antevs' interpretations; that the lake dried completely in middle-Lake Lahontan time is contrary to Antevs' interpretation but in line with Russell's; and that the lake reached its highest level in early Lake Lahontan time is as Antevs inferred, but contrary to Russell's conclusion.

It now seems possible to correlate the later Quaternary stratigraphic units of the Carson Desert with those of the Lake Bonneville and Sierra Nevada areas, largely by means of soil stratigraphy. The successions in all three areas have similar soil sequences, in terms of relative age and relative development of the soils. The physical record in each area indicates that the soils formed during distinct widely separated intervals, in response to infrequent combinations of climatic factors that induced erosional stability and a more rapid rate of chemical weathering than normal. The most strongly developed soils formed during the main intervals of lake desiccation and deglaciation; weaker soils formed during the shorter recession 
LAKE LAHONTAN: GEOLOGY, CARSON DESERT, NEV.

intervals ; soil-profile development at other times was inappreciable. The soil-forming intervals were periodically repeated parts of whole climatic cycles-mainly fluctuations in temperature and precipitation-that are manifest in the Quaternary sequences of each area. The climatic cycles, and the depositional and soil-forming cycles induced by them, probably were virtually synchronous over the entire Rocky Mountain to Sierra Nevada region because the whole region probably acted as a climatic unit during the Quaternary as it does now. Thus, soils of similar relative age and development in the four areas are assumed to have formed contemporaneously. Because they formed during generally shorter intervals than the intersoil sediments, they are considered to be more precise time-stratigraphic markers. The stronger soils are readily recognizable in the successions of each area and are the most reliable and useful markers; they provide the basic framework for correlation. The sediments and weaker soils intermediate in age between the main soils are correlated by matching those units that record depositional cycles, or parts of cycles, of similar relative age and similar climatic genesis; that is, units recording early lake cycles are matched with each other and with units recording early glacial cycles; likewise, lake-recessional units are correlated with glacial-recessional units.

By this method the Cocoon soil is correlated with the preWisconsin soil of Hunt and Sokoloff (1950) in the Lake Bonneville and Rocky Mountain areas and with the soil of preTahoe age (of Blackwelder, 1931) in the Sierra Nerada; the Churchill soil is correlated with the middle Lake Bonneville soil and with the soil of inter-Tahoe Tioga age (of Blackwelder, 1931) in the Sierra Nevada. The Toyeh soil is correlated with soils of post-Lake Bonneville and post-Tioga time. The deposits intermediate in age between these main soils are correlated as follows: The Eetza formation is correlated with the Alpine and Bonneville formations of the Lake Bonneville area, and with the deposits of the Tahoe glacial stage in the Sierra Nevada. The Wyemaha formation is correlated with subaerial deposits of inter-Bonneville-Provo age in the Lake Bonneville area and with disconformities of inter-Tahoe-Tioga age in the Sierra Nevada. The Sehoo and Indian Lakes formations are correlated with the main part of the Provo formation of the Lake Bonneville area, and with deposits of the Tioga glacial stage in the Sierra Nevada. "The Turupah formation is correlated with deposits of Antevs' altithermal age (2000 to 5500 B.C.) in the Great Basin. The Fallon formation is correlated with deposits of Antevs' medithermal age in the Great Basin and with deposits of Matthes' Little Ice Age in the Sierra Nevada.

These correlations, if valid, lead to several general deductions about regional Quaternary events :

1. The fluctuations of Lakes Lahontan and Bonneville were similar and synchronous.

2. The fluctuations of both lakes paralleled those of the glaciers in the Sierra Nevada; when the lakes were high the glaciers were extensive. The more complete record in the basins gives indirect evidence of glacial oscillations not yet recognized in the mountains.

3. Lake Lahontan, and probably Lake Bonneville, dried up entirely during a long period between the two major deep-lake intervals, and the Sierra Nevada was probably then completely deglaciated.

4. The major lake rises were caused by increased runoff and decreased evaporation and transpiration during a cooler and wetter climate than the present one. The climate during the maximums of the main intervals of lake desiccation was prob- ably warmer and drier than at present, but during the later parts of these intervals, when the stronger soils formed, it probably was warmer and wetter.

\section{INTRODUCTION}

This report describes the geology of the southern part of the Carson Desert, near Fallon, Churchill County, Nev. The rocks exposed range in age from early Tertiary (?) to Recent. All were mapped and studied, but the main emphasis was placed upon the late Quarternary deposits, especially those of Lake Lahontan.

Lake Lahontan is used here in the sense used by Russell $(1885$, p. $250-253,270)$, as the series of deep-lake fluctuations (lake cycles) of Pleistocene age whose deposits and shore features are prominently exposed in the highlands, together with intervening lake recessions, but excluding earlier lake fluctuations that are poorly recorded, earlier lake recessions, and subsequent very shallow lakes of Recent age.

Quarternary stratigraphic research has been mostly in continental areas draining to the ocean, where the deposits record only part of the time they embrace: such areas generally either received no sediments or were being eroded during long intervals of the Quaternary. In contrast, the terminal basins of the larger rivers of the Great Basin preserve a virtually complete depositional record of later Quaternary time, because no sediment has been lost by exterior drainage. The Carson Desert is the sink for nearly 60 percent of the Lake Lahontan drainage area. The area mapped extends from the lowest parts of the basin to well above the highest shoreline of Lake Lahontan; thus not only the larger late Quaternary lake fluctuations may be determined, but even minor low-level ones and minimum levels of lake recession and desiccation; hence, the record is uncommonly complete in detail. Key data are provided for problems in climatology, pedology, archeology, and ecology.

\section{LOCATION}

The area lies in Churchill County, Nev., and is bounded by lat. $39^{\circ} 14^{\prime} 30^{\prime \prime}$ and $39^{\circ} 45^{\prime} \mathrm{N}$., and long. $118^{\circ}$ $28^{\prime} 45^{\prime \prime}$ and $119^{\circ}$ W. (fig. 1). It includes about 845 square miles in the southern Carson Desert, which is the largest intermontane basin in the northwestern Great Basin, and parts of several small mountain groups and small basins to the south, southeast, and southwest. It embraces the Stillwater and Carson Lake 15-minute quadrangles, most of the Fallon quadrangle and the southeastern two-thirds of the Soda Lake quadrangle (pls. 2-6). 


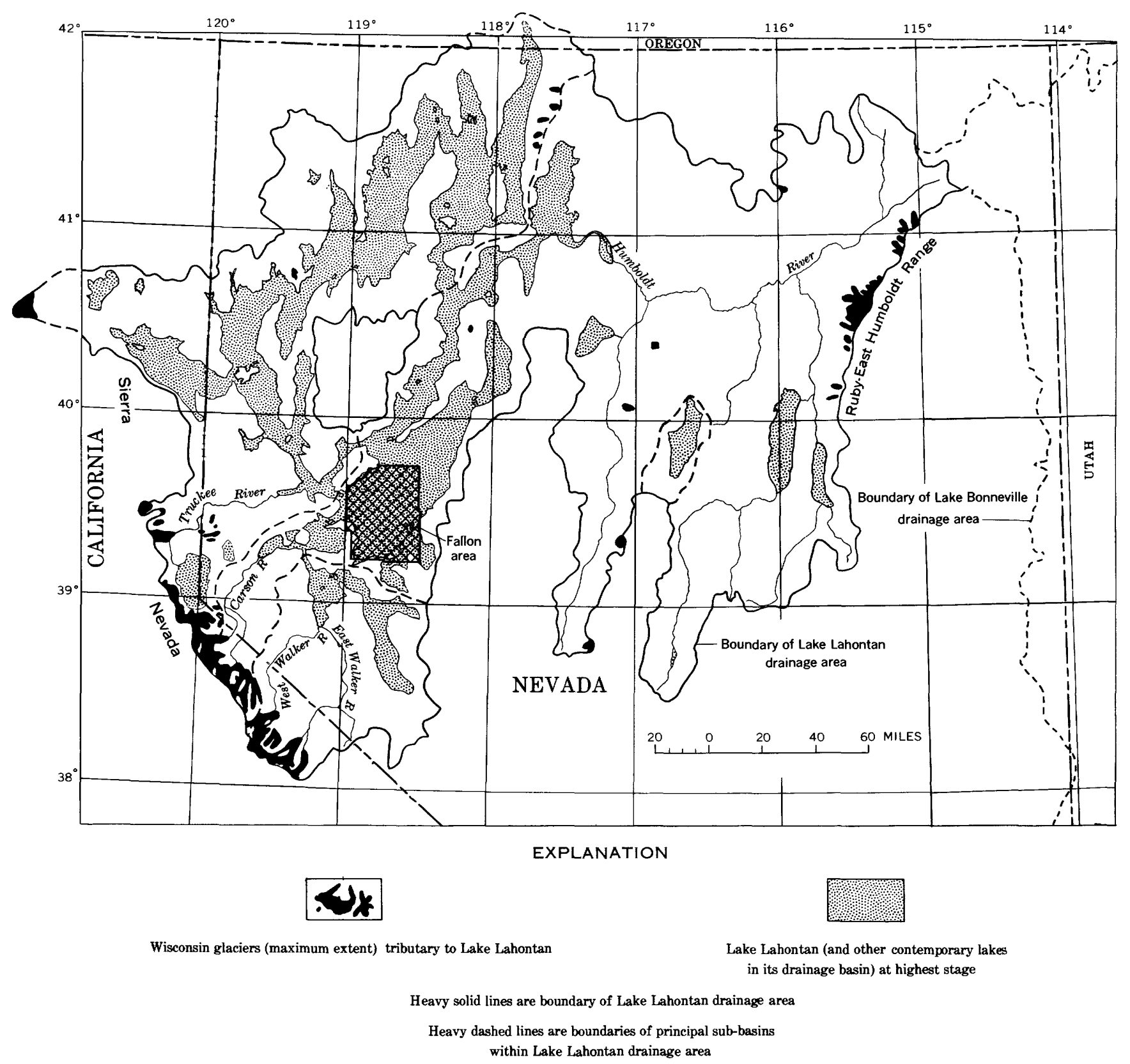

FIgURE 1.-Map showing location of report area and area inundated by Lake Lahontan.

\section{FIELDWORK}

Fieldwork started in June 1947 and continued intermittently through the fall of 1950 . John C. Reed, Jr., Mrs. Margaret M. Wheat, Calvin C. Covell, William N. Gilliland, Henry H. Woodard, Jr., Steven S. Oriel, Miss Helen M. Herald, and Henry J. Moore 2d assisted at various times.

The Carson Lake and Stillwater quadrangles were mapped on aerial photographs of $1: 2,000$ scale. The Fallon and Soda Lake quadrangles were mapped in less detail-mostly on aerial photographs of $1: 24,000$ scale. Aerial color phototransparencies of $1: 12,000$ and $1: 6,000$ scales gave additional help in some areas. Special field methods used for study of the Quatemary deposits are discussed on pages 17-18.

Good topographic maps were not available until after the geologic mapping was completed. The only topographic maps available during the mapping were of the Carson Sink quadrangle, scale $1: 250,000$ with a 100 foot contour interval, and special township topographic maps, scale $1: 15,840$, surveyed in $1903-05$ by the former Hydrographic Branch of the U.S. Geological Survey. The township maps have a 5-foot contour interval and cover two-thirds of the lowlands of the map area, but 
LAKE LAHONTAN: GEOLOGY, CARSON DESERT, NEV.

they do not extend into the highlands. They aided in determining the altitudes of the shorelines of lowlevel lakes, but their primary ground control was too unreliable for use as a mapping base. To obtain necessary vertical control to determine shoreline altitudes, about 25 miles of lines of levels were run along the highland shores of the Carson Lake quadrangle.

\section{ACKNOWLEDGMENTS}

Many scientists gave important assistance and advice in the field. Ernst Antevs visited the area twice. Arnold E. Withers, of the University of Denver, made a reconnaissance of the archeologic sites of the area with the writer in 1949. Robert F. Heizer and two of his graduate students, Norman L. Roust and Gordon L. Grosscup, of the University of California, Berkeley, Calif., investigated several archeologic sites. Hans Jenny and Robert Crocker of the same university examined the geologic relations of the soils with the writer. Maxwell E. Springer of the University of California made chemical and physical studies of the soils; some of his data are included in this report.

To many inhabitants of the region the writer is greatly indebted for courtesy and cooperation. Special thanks are due Miss Laura Mills, Mr. and Mrs. Wendell Wheat, George Forbes, and the late J. H. Johnston, of Fallon; Harry Richards, watermaster for the TruckeeCarson Irrigation District; William H. Slattery, area engineer for the U.S. Bureau of Reclamation; Vincent P. Gianella, University of Nevada; and Philip A. Laylander of Fallon, who took many of the aerial photographs used.

\section{PREVIOUS WORK}

The earliest account of the geology of the Carson Desert region is the narrative sketch by Henry Englemann, geologist for Capt. J. H. Simpson's expedition of 1858-59 (in Simpson, 1876). Englemann apparently was the first to recognize the shore features of Lake Lahontan as evidence of an ancient deep lake.

The first systematic geologic investigation of the region was the geologic exploration of the 40 th parallel, under the direction of Clarence King, assisted by Arnold Hague and S. F. Emmons (King, 1878; Hague and Emmons, 1877). The area mapped for the present study lies mostly south of the area mapped by Hague and Emmons. King gave Lake Lahontan its name, after Baron LaHontan, an early adventurer and explorer of this region. King discussed the ancient lake features, and gave a map showing the maximum area inundated. He postulated two deep-lake periods, separated by an interval of major recession or complete desiccation; this postulate was based on a hypothetical chemical history of the tufa deposits, which he believed to be pseudomorphic after gaylussite that was deposited on the recession of the first lake cycle. He thought that the lake probably overflowed at its highest levels for, although he knew that Lake Lahontan had no outlet in the area examined, he believed reports of an outlet to the south. King grouped most of the Lake Lahontan sediments with his Humboldt Pliocene formation and some with his Truckee Miocene beds.

The classic study of Lake Lahontan by Israel C. Russell between 1881 and 1883 was published as U.S. Geological Survey Monograph 11 (Russell, 1885). Russell and his assistants, Willard D. Johnson and W. J. McGee, covered in reconnaissance the whole Lake Lahontan basin, more than 20,000 square miles, noting both geomorphic features such as beach terraces, bars, and spits, as well as the stratigraphy of the lake deposits. Russell's interpretation of the lake history has proved generally correct.

In the river trenches Russell observed two zones of lake clay and silt ("upper lacustral clay" and "lower lacustral clay") separated by a zone of fan alluvium and lake gravel and sand ("medial gravel") and correctly inferred two deep-lake periods separated by a long interval of probably complete desiccation. From detailed mapping of shore terraces and spits in several localities, he reasoned that the highest level of the first lake cycle was about 30 feet lower than that of the second; evidence for a contrary interpretation is given on pages $64-65$ of this report. Russell determined that that lake did not overflow at any time.

Russell's study is the only one that has covered the whole area of the ancient lake. Several geologists later studied parts of the area, notably J. C. Jones (1925, 1929), Ernst Antevs (1925a), and G. M. Stanley (1949). No geologic mapping was published from any of these later studies, but Antevs published detailed stratigraphic sections of lake sediments exposed in the valleys of the Truckee and Humboldt Rivers.

D. F. Hewett in 1922, and R. W. Richards in 1946, made brief reconnaissances of the oil and gas possibilities of the Fallon area for the U.S. Geological Survey. No reports of these investigations have been published, but the field records and logs of oil and gas test wells and water wells have been helpful in this study.

\section{GEOGRAPHIC SETTING}

The arid desolation of the Carson Desert area outside the irrigated farming district appeals to few people, and indeed repels most. Few parts of the United States have so starkly forbidding an aspect of parched lowlands and somber mountains, with only the scantiest verdure. 


\section{MAJOR LANDFORMS}

CARSON DESERT AND ADJOINING BASINS

Carson Desert, the intermontane basin surrounding Carson Sink and Carson Lake, is the largest intermontane basin in northern Nevada. This basin is elongate northeastward, and is 70 miles long and 8 to 30 miles wide (pl.1). It is the southern part of a northeastwardtrending trough 125 miles long, and is separated by only a low divide from Buena Vista Valley, the northern basin of this trough. Most of the Carson Desert is below an altitude of 4,000 feet. The highest large area of interior lowlands is an old delta that borders the valley of the Carson River near Lahontan Dam, at an altitude of about 4,100 feet. The lowest parts of the basin are: Carson Sink, a playa 20 miles in diameter in the northern part of the basin at an altitude of about 3,860 to 3,880 feet; Carson Lake, a large shallow lake in the southern part of the basin at an altitude of 3,908 feet; and the Stillwater Lakes, a chain of small lakes, ponds, and swamps that extends 20 miles southwestward from Carson at an altitude of about 3,870 to 3,880 feet.

Carson Sink is nearly level, varying less than 10 feet in altitude in 20 miles across its central part; it is commonly heavily salt encrusted, and is completely barren except at the mouths of the Carson and Humboldt Rivers, where patches of saltgrass are watered by intermittent overflow. On the west, north, and east the sink lies close to the piedmont slopes of the bordering mountains, but on the south and southwest 12 to 34 miles of lowlands intervene. Although the local relief is small, the lowlands are rough in detail and have a topography peculiar to areas of strong wind action.

The lowlands away from the river flood plain consist of irregular sanclhills, sand plains, and clay flats. The sandhills are mostly dunes; some are stabilized and others active. Locally they make up three-fourths of the terrain and rise as much as 50 feet above the general surface; elsewhere they are few and small, or lacking. The strongly developed dunes commonly form discontinuous long parallel ridges that trend eastnortheastward, and are separated by bare flats or shallow deflation basins. The clay flats are scattered, but they are most niumerous and largest near the sink.

Through this complex the Carson River has formed its flood plain. At Lahontan Dam the flood plain is incised 120 feet below the general surface, but the river trench gradually becomes shallow downstream. About $41 / 2$ miles west of Fallon the trench is only a few feet deep, and the flood plain fans out over an area of $120^{\circ}$. This lower flood plain, shaped like a ragged fan, merges downstream with the almost level plains-former lake floors-that border Carson Lake, Carson Sink, and the Stillwater Lakes.

Interrupting the lowlands south of the Carson Sink are three low volcanic hills: Rattlesnake Hill, the Soda Lakes uplift, and Upsal Hogback.

Several side basins extend southeastward to southwestward from the main basin between the bordering mountains: Salt Wells Basin, the largest, is 16 by 6 miles and floored mainly by playas (Turupah, Eightmile, and Fourmile Flats) ; the basin drained by Diamond Field Jack Wash is 12 miles long and 3 to 6 miles wide, with Bass Flats at its northern end; the basin drained by Sam Spring Wash is also included with these side basins.

\section{HIGHLANDS BORDERING THE BASINS}

The nearly straight Stillwater Range (formerly called the Paiute or Pah-Ute Range) borders the Carson Desert on the east. The north and central sections of this range are 4 to 10 miles wide; the highest of the peaks above an altitude of 8,000 feet is Jobs Peak $(8,806 \mathrm{ft})$. South of Mountain Well the range is lower and wider and consists of several parallel ridges from which a small spur extends into the map area.

Along the south and west borders of the Carson Desert are several groups of low mountains that have crest altitudes of 4,500 to 6,000 feet: the Lahontan, Bunejug, Cocoon, White Throne, Desert, Dead Camel, and Hot Springs Mountains.

\section{CIIMATE}

The Carson Desert is one of the driest and warmest parts of northern Nevada, owing to its moderate altitude and its position in the rain shadow of the Sierra Nevada. The climate is continental in the extreme, with warm summers, cold winters, wide diurnal temperature range, and relatively wide fluctuations in annual rainfall. Cloudless skies are the rule, strong winds are frequent, and evaporation is high.

Precipitation.-Meteorologic records for Fallon and Lahontan Dam are given in tables 1 and 2. The mean annual precipitation at Fallon during the 55-year record prior to 1952 was 4.95 inches. Three-fourths of the precipitation falls between December and May. As in most arid regions, annual precipitation varies widely from year to year; extremes of about 2 and 8 inches have been recorded. At Lahontan Dam the mean annual precipitation for the 44-year record prior to 1952 was about 4.35 inches; extremes have been about 1 and 9 inches. Precipitation in the surrounding mountains is undoubtedly higher but has not been recorded. Even the higher parts of the Stillwater Range contribute little runoff, however, because of the small drainage area 
TABLE 1.-Climatic data at Fallon (Agricultural Experiment Station), Churchill County, Nev. [Altitude 3,965 feet]

\begin{tabular}{|c|c|c|c|c|c|c|c|c|c|c|c|}
\hline \multirow[b]{2}{*}{ Period } & \multicolumn{5}{|c|}{ Temperature, in degrees Fahrenheit } & \multicolumn{4}{|c|}{ Precipitation, in inches } & \multirow{2}{*}{$\begin{array}{c}\text { A verage } \\
\text { number } \\
\text { of days } \\
\text { having } \\
\text { precipita- } \\
\text { tion } \\
>0.01 \text { in. } 1\end{array}$} & \multirow{2}{*}{$\begin{array}{l}\text { Prevailing } \\
\text { wind } \\
\text { direction }\end{array}$} \\
\hline & $\underset{\text { maximum } 1}{\text { Mean }}$ & $\underset{\text { minimum } 1}{\text { Mean }}$ & Mean ${ }^{2}$ & Highest 1 & Lowest 1 & Mean ${ }^{2}$ & $\begin{array}{c}\text { 24-hour } \\
\text { maximum }\end{array}$ & Highest 1 & Lowest 1 & & \\
\hline $\begin{array}{l}\text { January } \\
\text { February } \\
\text { March } \\
\text { April. } \\
\text { May } \\
\text { June- } \\
\text { July } \\
\text { August } \\
\text { September } \\
\text { October } \\
\text { November } \\
\text { December. } \\
\text { Year. }\end{array}$ & $\begin{array}{l}43.1 \\
50.6 \\
59.1 \\
66.4 \\
73.9 \\
83.9 \\
93.0 \\
90.8 \\
80.0 \\
68.4 \\
56.1 \\
44.3 \\
67.5\end{array}$ & $\begin{array}{l}16.6 \\
22.8 \\
27.5 \\
34.0 \\
40.7 \\
47.1 \\
54.0 \\
51.1 \\
42.0 \\
32.8 \\
23.9 \\
18.2 \\
34.2\end{array}$ & $\begin{array}{l}33.6 \\
36.0 \\
42.9 \\
50.3 \\
57.5 \\
65.1 \\
72.9 \\
70.6 \\
61.3 \\
51.1 \\
39.6 \\
31.8 \\
50.7\end{array}$ & $\begin{array}{r}70 \\
78 \\
79 \\
89 \\
102 \\
102 \\
105 \\
103 \\
97 \\
89 \\
81 \\
72 \\
105\end{array}$ & \begin{tabular}{r|}
-25 \\
-12 \\
8 \\
13 \\
21 \\
28 \\
38 \\
35 \\
22 \\
13 \\
-1 \\
-10 \\
-25
\end{tabular} & $\begin{array}{r}0.60 \\
.59 \\
.49 \\
.44 \\
.57 \\
.33 \\
.16 \\
.16 \\
.24 \\
.45 \\
.33 \\
.59 \\
4.95\end{array}$ & $\begin{array}{r}1.69 \\
.70 \\
1.50 \\
.87 \\
1.71 \\
.40 \\
.83 \\
1.23 \\
.75 \\
.73 \\
.80 \\
.83 \\
1.69\end{array}$ & $\begin{array}{c}2.34 \\
1.56 \\
1.88 \\
2.14 \\
2.73 \\
1.00 \\
1.53 \\
1.90 \\
1.50 \\
1.95 \\
1.16 \\
2.02 \\
8.09 \\
(1913)\end{array}$ & $\begin{array}{c}\text { Trace } \\
0 \\
0 \\
0 \\
0 \\
0 \\
0 \\
0 \\
0 \\
0 \\
0 \\
0 \\
2.22 \\
(1929)\end{array}$ & $\begin{array}{r}4 \\
4 \\
4 \\
3 \\
4 \\
2 \\
1 \\
2 \\
2 \\
3 \\
2 \\
4 \\
35\end{array}$ & $\begin{array}{l}\mathbf{N} \\
\mathbf{N E} \\
\mathbf{S W} \\
\mathbf{W} \\
\mathbf{W} \\
\mathbf{W} \\
\mathbf{W} \\
\mathbf{W} \\
\mathbf{W} \\
\mathbf{W} \\
\mathbf{N} \\
\mathbf{N} \\
\mathbf{W}\end{array}$ \\
\hline Number of years of record & 26 & 26 & 49 & 26 & 26 & 57 & 37 & 35 & 35 & 36 & 36 \\
\hline
\end{tabular}

1 From "Climatic summary of the United States, from the establishment of the Station to 1930, inclusive; section 19, Nevada": U.S. Weather Bur., 1933. 2 From "Climatological Data, Annual Summary, 1951"; v. 66, no. 13 (Nevada): U.S. Weather Bur., 1952.

and high evaporation. The Carson River, which flows from the Sierra Nevada, furnishes nearly all the surface inflow to the Carson Desert.

Heavy local downpours occur occasionally over the mountains, but they are generally many years apart in the low mountains within the map area. Thunderstorms are infrequent. Snow is rare and generally light in the lowlands and low mountains and rarely lingers more than 1 or 2 days, but the higher parts of the Stillwater Range are snow covered during most of the winter.

More than 80 years of weather records in the Truckee River drainage area, supplemented by tree-ring and lake-level studies (Hardman and Venstrom, 1941), show alternate periods of above-average or below-average precipitation from 2 to 20 years long, some broken by single years of opposite character. Precipitation was

TABLE 2.-Climatic data at Lahontan Dam, Churchill County, Nev.

[Altitude 4,200 feet]

\begin{tabular}{|c|c|c|c|c|}
\hline \multirow{2}{*}{ Period } & \multirow{2}{*}{$\begin{array}{c}\text { Mean 1 } \\
\text { tempera- } \\
\text { ture, in } \\
\text { degrees } \\
\text { Fahrenheit }\end{array}$} & \multicolumn{3}{|c|}{ Precipitation, in inches } \\
\hline & & Mean ${ }^{1}$ & Highest ${ }^{2}$ & Lowest ${ }^{2}$ \\
\hline \multirow{9}{*}{ 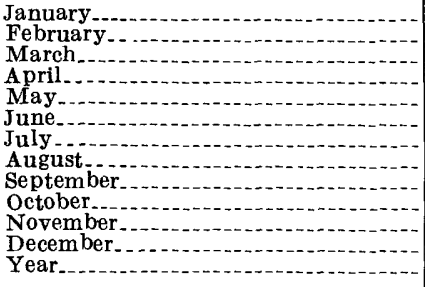 } & \multirow{9}{*}{$\begin{array}{l}31.2 \\
37.0 \\
44.5 \\
52.0 \\
60.6 \\
68.9 \\
78.1 \\
76.1 \\
65.9 \\
54.5 \\
42.5 \\
34.0 \\
53.8\end{array}$} & \multirow{9}{*}{$\begin{array}{r}0.56 \\
2.38 \\
.30 \\
.40 \\
.48 \\
.34 \\
.17 \\
.22 \\
.27 \\
.37 \\
.29 \\
.51 \\
4.35\end{array}$} & & \\
\hline & & & & - \\
\hline & & & & \\
\hline & & & & \\
\hline & & & & \\
\hline & & & & -.... \\
\hline & & & & \\
\hline & & & & \\
\hline & & & 38.98 & 41.20 \\
\hline Number of years of record & 40 & 44 & & \\
\hline
\end{tabular}

1 Data from "Climatological Data, Annual Summary," 1951; v. 66, no. 13 (Nev.): U.S. Weather Bur., 1952.

2 Data from "Climatic summary of the United States from the establishment of the Stations to 1930, inclusive;"' section 19, Nevada: U.S. Weather Bur., 1933. 4 For 1928 . generally higher than average from 1889 until about 1915, but was lower than average from 1915 until 1934, an extremely dry year, and has been above average since 1934.

Temperature.-The maximum temperature recorded at Fallon during the 49 -year period of record prior to 1954 was $106^{\circ} \mathrm{F}$, and the minimum, $-25^{\circ} \mathrm{F}$, an extreme range of $131^{\circ} \mathrm{F}$. The average January temperature is $29.8^{\circ} \mathrm{F}$; average July temperature $74.1^{\circ} \mathrm{F}$; and the mean annual temperature, $50.7^{\circ} \mathrm{F}$. The mean annual temperature at Lahontan Dam is $53.8^{\circ} \mathbf{F}$. In July and August temperatures commonly reach the low nineties, but nights are cool, commonly below $45^{\circ} \mathrm{F}$. Frosts continue until late spring and commence in early fall, so that the growing season averages only about 125 days. Winter minimums are rarely below $-5^{\circ} \mathrm{F}$. Long-term temperature fluctuations are not pronounced and do not correlate with the precipitation changes.

Wind.-The average annual wind velocity at the Fallon Agricultural Experiment Station during 190915 was $3.75 \mathrm{mph}$; the highest monthly average (April) was but $5.4 \mathrm{mph}$. Sudden strong but brief windstorms are common in spring and early fall, and redistribute much dust and sand. Small summer whirlwinds ("dust devils") lift dust several hundred feet, where upper air currents may carry it for long distances.

Evaporation.-Humidity is low, and the annual evaporation rate exceeds precipitation by a ratio of about 12 to 1 . The average annual evaporation from a BPI pan set in the ground at the Agricultural Experiment Station near Fallon from 1908 to 1916 was 64 inches, which is equivalent to a free-water evaporation of about 58 inches.

A standard floating pan at Lahontan Dam showed a mean annual evaporation of about 74 inches for the 16 
years prior to 1950 . The relative amount of evaporation from this pan was probably close to that from the lake itself.

\section{DRAINAGE}

Carson Sink is the sump for both the Humboldt and Carson Rivers, whose combined drainage area of 26,000 square miles is 57 percent of the total for Lake Lahontan. The Humboldt overflows Humboldt Lake only occasionally through White Plains playa into the sink, but the Carson River reaches the sink during most of the year, particularly since development of the Newlands Reclamation Project.

The Carson River enters the basin at Lahontan Dam and has been the major contributor of sediment to the southern part of the basin. It drains about 5,900 square miles, but of this only 1,300 square miles is above Lahontan Dam, and most of its volume comes from 800 square miles in the Sierra Nevada. The Humboldt River is now controlled by Rye Patch Reservoir, and the Carson by Lahontan Reservoir. The Carson, augmented by water from the Truckee River, irrigates more than 90,000 acres in the Newlands Reclamation Project. The channel of the Carson from Lahontan Dam to Carson Sink formerly was meandering 8 miles south of the sink and it divided into several distributary channels; now the river has been straightened, deepened, and confined within a single channel except where artificial diversions are made.

The interior lowlands are so arid that even ephemeral-stream courses are very rare. Large areas are without sign of drainage, and the remainder have widely spaced small short gullies that flow only after infrequent heavy rains.

Waste water from the irrigation project feeds Carson Lake, the Stillwater Lakes, Carson Sink, and the Indian Lakes. The Stillwater Lakes, which have the largest water area of these four, consist of many interconnected ponds and small lakes that have intervening marshes and islands. They are fed from the south by Stillwater Slough and drainage canals of the reclamation project, and they intermittently overflow northward into Carson Sink. Prior to 1940 the lake area was about 12 miles long and 4 miles wide, but it is being enlarged by the U.S. Fish and Wildlife Service to develop new lake and marsh areas for waterfowl.

Carson Lake consists of marshland and shallow open water and is about 7 miles long and 5 miles wide at the current highest stage; it was formerly larger, but has been lowered by deepening Stillwater Slough, which is the outflow channel into the Stillwater Lakes. The Indian Lakes include more than 30 small lakes and ponds formed by irrigation waste water in deflation and interdune basins.
The water area of Carson Sink has varied considerably in recent years. During the 1860's and 1870's it was a permanent lake that measured about 15 by 20 miles and extended to about the 3,880-foot contour line, so that Pelican Island actually was an island (Antevs, 1938 b, p. 30). Since then, however, the sink generally has held water only part of the year, and for several decades it has been generally dry except for a small area near the mouth of the Carson River. High river discharge flooded it extensively during the winters of 194344 and 1950-51, but each time this water evaporated during the following summer.

\section{VEGETATION}

The vegetation, which reflects the aridity, is the northern desert shrub association, dominated by desert shrubs, herbs, and grasses. It is closely controlled by soil conditions and drainage. The characteristic plant associations of this area have been described by Billings (1945), who showed the relation of the main associations to topographic and geologic position (fig. 2).

The little greasewood-shadscale association is the climax assemblage on the well-drained lowlands and low mountains of the map area. It consists of low spiny shrubs that cover 5 to 12 percent of the ground; these shrubs are generally evenly spaced and separated by bare ground. The dominant species are little greasewood (Sarcobatus baileyi), shadscale (Atriplex confertifolia), and bud sagebrush (Artemisia spinescens); Ephedera nevadensis occurs locally, and in the transitional zone between the mountains and lowlands some hopsage (Grayia spinosa) and white sage (Eurotia lanata) are present. Perennial herbs and annuals generally are sparse or absent.

Other plant associations are restricted to relatively small areas of abnormal soil or drainage conditions. The Dalea association, typified by the small shrubs and perennial herbs Dalea polyadenia, Atriplex canescens (shadscale), Tetradymia comosa, and T. glabrata, and locally IIymenoclea fasciculata and Oryzopsis hymeno$i d e s$, is limited to areas of eolian sand. The association is prominent where the sand is stabilized, particularly in the western lowlands south of Carson Sink and in the sandy passes in the highlands. The association characterized by big greasewood (Sarcobatus vermiculatus), occupies saline clayey soil at the edges of playas and poorly drained lowlands where the subsoil always is moist but the surface crust dries in late summer. The rabbitbrush association, characterized by two kinds of rabbitbrush, Chrysothamnus nauseosus var. consimilis and $C$. nauseosus var. holoeucus, is largely limited to recently drained or disturbed ground. 


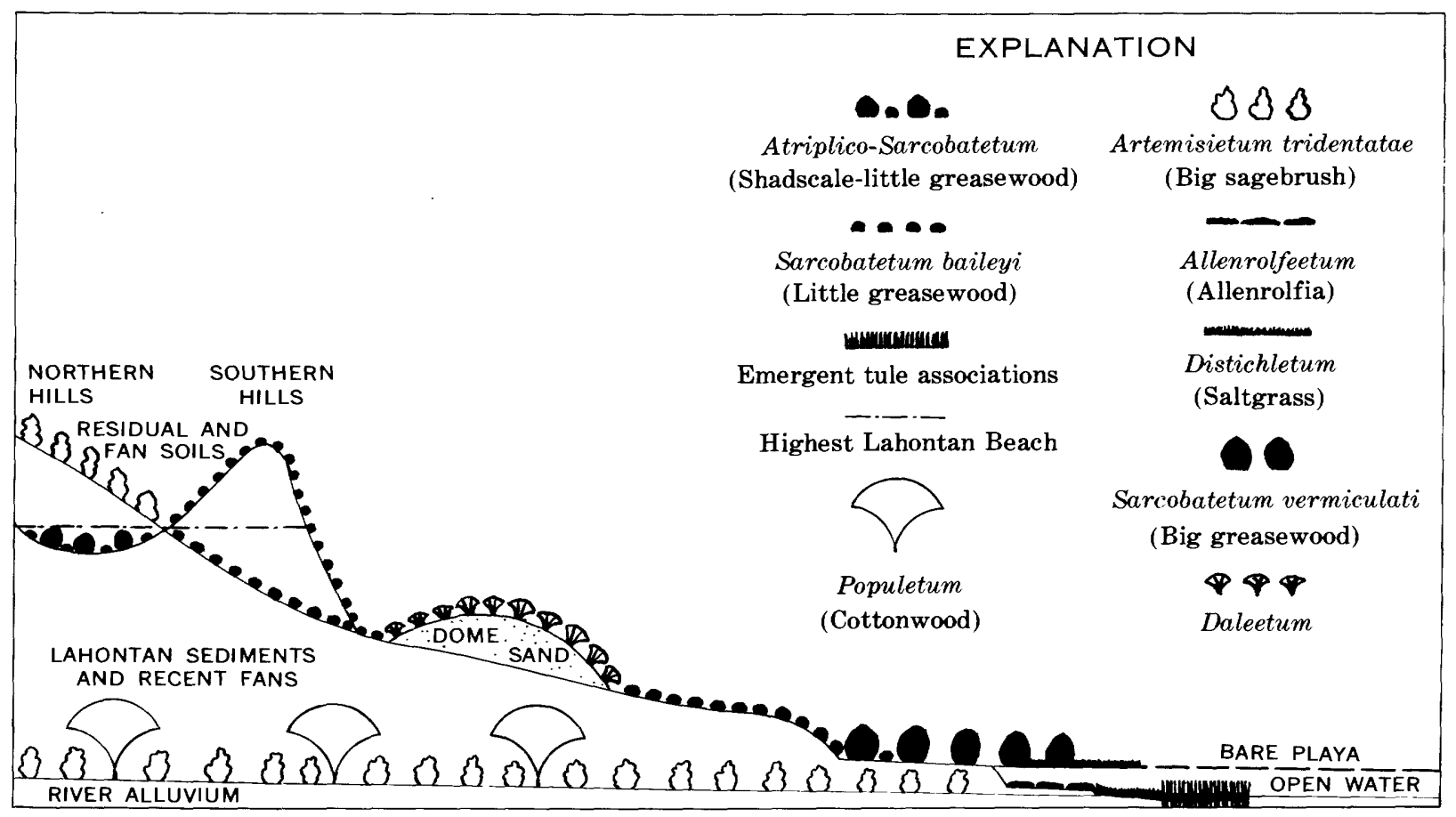

Figure 2.-Diagram of the topographic and geologic positions of the principal plant associations in the Carson Desert region. From Billings (1945, fig. 4).

The saltgrass association, consisting dominantly of desert saltgrass, Distichlis stricta and locally D. spicata, is found on soils that range from moderately to intensely saline, except the very driest. It borders the more permanent playas, ponds, streams, and marshes.

The cottonwood association consists of cottonwood (Populus fremontii) and willow, the only native trees in the area, and big sagebrush (Artemisia tridentata); these plants border stream courses and some lakes and ponds where the soil is relatively nonsaline. The association is widespread on the river flood plain and was the original cover on much of the farmland. Russian olive, an introduced tree that has become naturalized, is now widespread in this association.

\section{ECONOMIC GEOGRAPHY}

Population, torens, and settlements.-The population is restricted to the irrigated district and a scattering along the main highways. Fallon, the county seat of Churchill County, is the only town, and had a population of 2,700 in 1960. The village of Stillwater, in the eastern part of the irrigated district, was formerly the principal settlement and county seat, but has gradually declined in importance since 1908, when Fallon became incorporated, and now has only a general store and about eight homes. Salt Wells is a roadhouse and motel on U.S. Highway 50 on the northeast side of Turupah Flat; they are operated by a single family.
Transportation.-In the days of the Emigrant Trail the Carson Desert was notorious as the "Forty-mile Desert," one of the most difficult stretches of the Overland route. The Southern Pacific Railroad crosses the west edge of the desert from White Plains siding to Hazen, and has a spur line from Hazen to Fallon. U.S. Highways 50 and 95 intersect at Fallon, providing excellent surfaced highways to Ely on the east, Tonopah on the south, and Reno and Carson City on the west. Several hard-surfaced roads radiate from Fallon.

Outside the farming area roads are few and poor, except for the main highways, although the county maintains some graded roads to mines and outlying ranches. Sand, during the drier parts of the year, and sticky mud on the clay flats after rains, impede travel. Much of the map area is accessible only by 4 -wheel-drive vehicles, or by horse or foot.

Agriculture.-All crops are irrigated. About 50,000 acres of cropland (about 10 percent of the total farmland in Nevada) have been developed under the Newlands Reclamation Project-the first Federal reclamation project-which was started in 1903. It utilizes water from both the Carson and Truckee Rivers, stored at Lahontan Reservoir 15 miles west of Fallon. Since completion of this reservoir in 1915 the water supply has been seriously short only in 1931 and 1934. In addition to the canals and reservoirs, the project lands in the Carson Desert are served by deep drain- 
age canals that prevent waterlogging of the land and remove accumulated alkali, both formerly serious problems.

The 125-day average annual growing season permits the growing of alfalfa (three cuttings) and most temperate-zone staple crops, vegetables, and hardy fruits. The large compact area of irrigated land, full-season water supply, and good transportation facilities favor cash-crop farming, but most of the farmland still is used for hay, grain, and pasture.

A few range cattle are grazed in the Carson Desert and surrounding mountains. The range in the interior of the basin is limited to intermittently flooded lowlands which support more than the usual forage cover. In the low mountains at least 30 acres per cow per month are required, and grazing is limited mainly to winter and early spring. The higher parts of the Stillwater Range furnish the best range because of the more abundant precipitation.

\section{TERTIARY STRATIGRAPHY AND STRUCTURE STRATIGRAPHY}

The pre-Quaternary rocks of the map area consist of volcanic and sedimentary rocks that range in age from Miocene or earlier to late Pliocene. No pre-Tertiary rocks are exposed, although such rocks crop out extensively in nearby ranges. Details of the stratigraphy and structure of the Tertiary rocks were studied only in the Carson Lake quadrangle and in the eastern part of the Desert Mountains in the Fallon quadrangle, and this discussion refers only to those areas.

The Tertiary rocks are divided into five main map units (table 3 ). One consists mainly of tuff and tuffaceous sediment; the others are largely flow rocks, ranging in character from basalt to rhyolite, and minor dikes and pyroclastic beds. The volcanic rocks range rather widely in composition in each formation, but petrologic details have not been studied. Correlations are lithologic, and must be considered tentative.

\section{BASALT OF RAINBOW MOUNTAIN}

The oldest rocks exposed are altered basalts and tuffs, exposed only at Rainbow Mountain (T. 18 N., R. 31 E.), from which they are named informally. They are pervasively sheared, closely faulted, and much altered. The principal rock is dark-greenish-gray to black altered basalt(?), which is generally weathered along joints to dark chocolate brown or maroon. It is mostly vesicular or amygdaloidal. Determinable feldsparthat of the phenocrysts only-is labradorite, and the

TABLE 3.-Major Cenozoic rock-stratigraphic units in the southern Carson Desert area

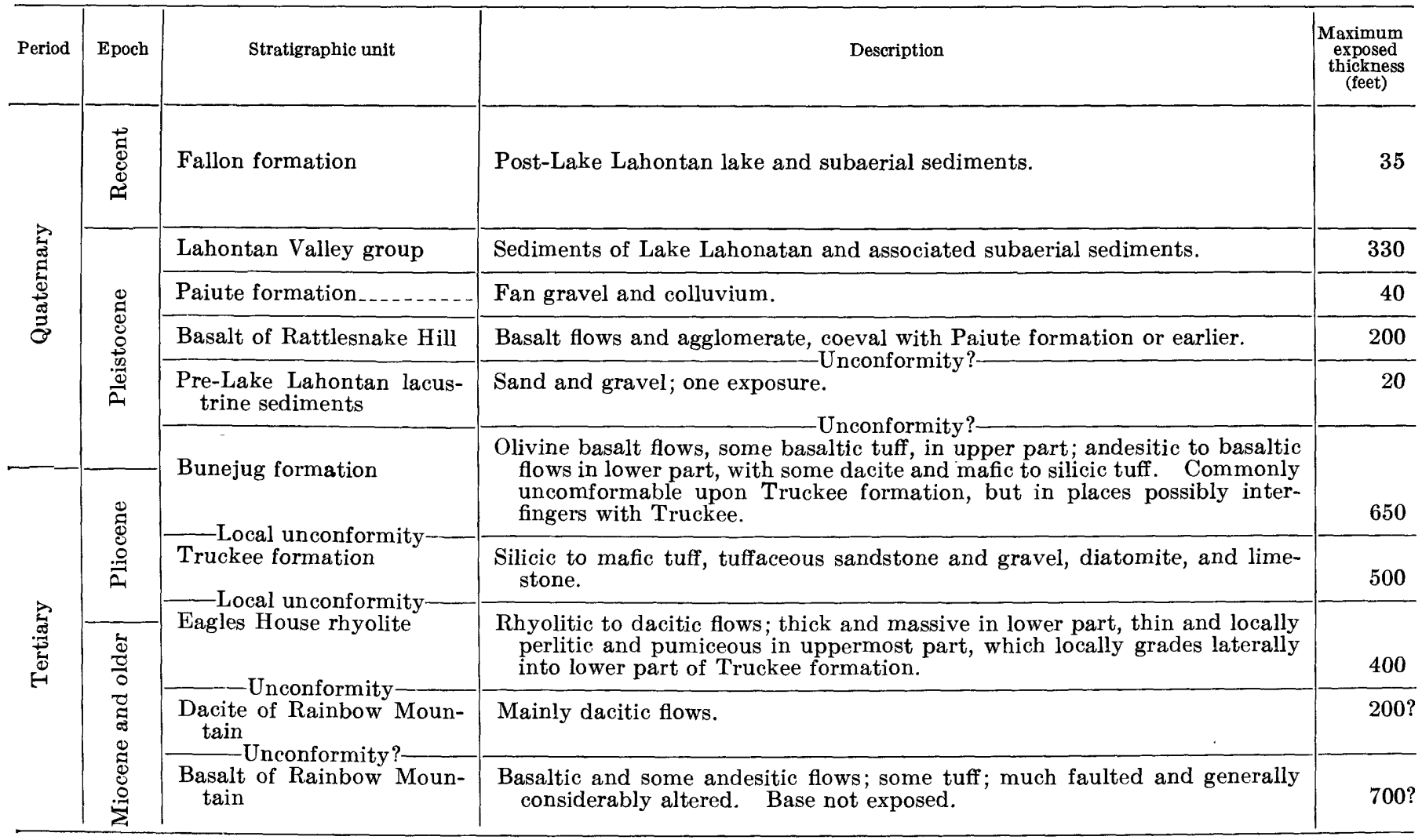


accessory minerals are olivine, augite, hornblende, and magnetite; even in the freshest specimens these minerals are largely altered to chlorite and calcite.

The flows tend to form prominent ledges. Intercalated with the dark flows are light- to medium-gray ones characterized by abundant carbonate amygdules. Also interbedded locally are thin red to maroon beds that appear to be highly altered mafic tuff and red to purple beds of volcanic breccia. Some of these rocks are probably andesites.

The apparent thickness, disregarding faulting, is about 1,400 feet, but the faults produced more repetition than omission of beds, and the true thickness is probably not more than 700 feet.

The volcanic rocks of Rainbow Mountain have yielded no fossils. The basalt is considerably more deformed and altered than the overlying dacite, which is in turn older than Miocene to Pliocene rocks, so the basalt is Miocene or older.

\section{DACITE OF RAINBOW MOUNTAIN}

The dacite of Rainbow Mountain is a distinctive series of light- to dark-gray, maroon, and purple strongly banded dacite that ranges to quartz latite and rhyolite. It is exposed in three fault blocks in southern Rainbow Mountain. In the northwestern block, the largest, on the west slope of the 4,645-foot peak, the dacite overlies the basalt of Rainbow Mountain with a westward dip of about $20^{\circ}$ to $30^{\circ}$. Whether this contact is conformable or not is uncertain because of small faults. The contacts of the other two areas are faulted or concealed, but fault displacements suggest the same sequence. The thickness of the dacite is uncertain because of faulting but is at least 200 feet.

The dacite is much less altered and deformed than the basalt of Rainbow Mountain but more so than the overlying Eagles House rhyolite. The flow banding in the dacite commonly curves around angular mafic inclusions and shows contortions independent of the attitude of the flows. Local breccias are interbedded with the massive dacite, as are thin beds of light-gray to white tuff.

The dacite has yielded no fossils. It is probably older than both the Truckee formation and the Eagles House rhyolite. Although not in depositional contact with either, except in a single questionable occurrence of the Eagles House rhyolite (p. 11), the faults intervening between the rhyolite and the Truckee formation demand this relation. As the Truckee formation is early Pliocene, the dacite of Rainbow Mountain may be of Miocene or earlier age.

\section{EAGLes House RHYOLITE}

Outside the Rainbow Mountains the oldest Tertiary unit exposed is a series of rhyolites. It is here named from the spectacular Eagles House crags, in sec. 13, T. 18 N., R. 30 E., in the Lahontan Mountains, where it is best exposed. These crags are designated as the type locality of the formation. It also is exposed in the White Throne and Desert Mountains, and in Eetza Mountain.

Two bodies of rhyolite, each about a fifth of a square mile in area, and several smaller ones, aggregating about 350 feet in thickness, are exposed at and near Eagles House. This is a complexly block-faulted area which is structurally higher than the country nearby. The rhyolite is faulted against the Truckee formation, which in a few places lies in depositional contact on the rhyolite. The base of the rhyolite is not exposed.

At Eagles House two thick flows are evident; the upper flow, nearly 100 feet thick, is pink porphyritic rhyolite, and the lower, about 200 feet thick, is palegreenish-gray porphyritic dacite. The conformable contact between these flows is well exposed in the western part of the crags and dips $10^{\circ} \mathrm{S}$. Both flows have conspicuous contorted flow structures.

The lower flow is porphyritic biotite-hornblende dacite that contains abundant phenocrysts of labradorite, quartz, and biotite; these minerals occur in the groundmass also, with hornblende, chlorite, apatite, and magnetite. The upper flow is porphyritic biotite rnyolite that contains abundant phenocrysts of quartz, sanidine, and biotite; glass commonly forms much of the groundmass. Near faults, both flows commonly are strongly bleached, kaolinized, and silicified. Unaltered remnants stand out in bold forms, of which the Eagles House crags are the most striking. The sheeted structure and vertical jointing produce bizarre erosional shapes.

In several small fault blocks west and north of Eagles House the upper flow is overlain by as much as 20 feet of thin flows of light-red flow breccia, which has sparse phenocrysts in an aphanitic to glassy groundmass, and shows prominent flow structure.

In the southern and eastern parts of the White Throne Mountains, extensively exposed rhyolitic flows are considered to be correlative with the Eagles House rhyolite; maximum exposed thickness is about 400 feet. These flows also crop out in several small hills near Russell Pass, just south of the map area, and in the northeastern Desert Mountains. They are mostly felsitic or porphyritic-felsitic, but locally they are perlitic. They range in color from light to medium gray, and in places they have appreciable reddish or purple cast. 
Phenocrysts are sanidine, quartz, biotite, and locally plagioclase. Some flows are strongly flow banded, and the banding commonly is contorted. Breccia zones occur locally. In the southeastern White Throne Mountains, stony rhyolite commonly is overlain by and grades laterally into glassy to perlitic and pumiceous rhyolite, and the upper flows locally intertongue with the lower part of the Truckee formation.

A small body of rhyolite(?) having an exposed thickness of 100 feet crops out in three small areas at the southeast edge of Eetza Mountain near U.S. Highway 50. The dominant rock is pink flow-banded felsite containing sparse tiny phenocrysts of biotite, quartz, and feldspar. In the southernmost exposure, the felsite is overlain by several feet of flow-banded glassy rhyolite and by about 10 feet of perlitic obsidian, both dipping gently westward.

A rhyolite (?) flow 15 feet thick is exposed in a narrow fault sliver at the west edge of Rainbow Mountain. Although faulted against the dacite of Rainbow Mountain on the east, the rhyolite apparently conformably overlies rocks that may belong to the dacite unit in the sliver itself (the dacite is exposed in an area too small to show on the map). It is light-lavender-red felsite containing sparse small phenocrysts of biotite, hornblende, sanidine, and quartz in a glassy groundmass. This lone occurrence cannot be definitely correlated with the Eagles House rhyolite, but it may be the base of that formation. As it appears to be conformable on the dacite of Rainbow Mountain, it may indicate that only a short time intervened between them.

The rhyolite in each of the above areas is considered to be correlative, but there is no direct evidence for this. The overlap of conformable and locally gradational Truckee formation establishes that the Truckee sedimentation overlapped and directly followed eruption of rhyolite in the White Throne Mountains. As the Truckee formation is early Pliocene in age (p. 12) the Eagles House rhyolite is considered to be late Miocene to early Pliocene.

\section{TRUCKOE FORMATION}

King (1878, p. 412-414) gave the name Truckee group to a sequence of mainly tuffaceous sediments in northwestern Nevada that underlie the late mafic lavas and generally overlie rhyolite. "Fossil Hill," in the northeastern Hot Springs (Kaw-soh) Mountains, was King's type locality. He considered these sediments Miocene, but recent studies suggest an early Pliocene age. Although variable in lithology and now known to have been deposited in several separate basins, rather than in a single large one as King supposed, they constitute a major sedimentary unit in northwestern Nevada. The U.S. Geological Survey has adopted the name Truckee formation for this unit.

The Truckee formation is locally to extensively exposed in the Lahontan, White Throne, Desert, and Dead Camel Mountains. The lower part consists largely of silicic tuff ; much of it is pumiceous, relatively coarse, and unsorted. Higher in the formation water-laid sediments become dominant, and in places they seem largely lacustrine. The lithology varies greatly laterally as well as vertically and single beds or members cannot be traced far. Because of this variability as well as faulting and cover, even the local stratigraphy of the Truckee is imperfectly known in many areas; correlation between the separate highland areas is problematical.

Where its base is exposed, the Truckee appears to be locally conformable upon and intertonguing with the Eagles House rhyolite. In most places a pronounced angular unconformity separates the Truckee from the overlying Bunejug formation, but in the Bunejug and Cocoon Mountains the two units possibly may intertongue (p. 14).

In the Lahontan Mountains, the Truckee formation underlies most of Wyemaha Valley and other saddles, although largely concealed by Quaternary sediments, and is locally exposed in the mountains themselves. The lower beds in this area are coarse water-laid pumiceous rhyolite tuff, pebbly tuffaceous sandstone, and tuffaceous sandstone, 40 to 80 feet thick. In at least two places near Eagles House the formation appears conformable upon the Eagles House rhyolite: One is in a deep gully about 2,000 feet west of Eagles House where the contact is exposed for about 650 feet. The rhyolite is highly altered and cut by innumerable small shears. Beds of the Truckee, also altered, appear conformable upon it and are horizontal to gently dipping. Locally at the base are several feet of tuffaceous sandstone and pebbly tuffaceous sandstone containing fragments of Eagles House rhyolite; overlying the sandstone is about 20 feet of soft silty tuff, mostly deep reddish gray but locally light gray or buff; next, about 10 feet of coherent pebbly to sandy and locally limy tuff.

The second place is about half a mile farther north along the same gully, where a depositional contact between the two formations is exposed in another fault block. Here also both formations are highly altered, and the Truckee is mostly coarse pumiceous tuff.

Overlying the coarse lower zone is at least 200 feet of thick-bedded to thinly bedded shaly and diatomaceous tuff and tuffaceous sandstone, and some calcareous tuffaceous sand and limestone (table 10, section $33 \mathrm{~T}$ ). Overlying these beds is coarse practically nonbedded pumi- 
ceous and rhyolitic tuff of unknown thickness, followed by a zone of fine-grained white tuff, diatomaceous tuff, diatomite, and locally pumiceous sandstone or grit, commonly more than 50 feet thick. This zone is overlain in places by 8 to 45 feet of greenish-gray mafic tuff, which is here the top of the formation.

In the valley between Rainbow Mountain and Salt Wells Mountain, the Truckee formation is extensively exposed unconformably beneath the Bunejug formation. The Truckee consists mainly of pink, light-green, buff to white tuffaceous sandstone and siltstone, and a few beds of oolitic ostracod-bearing limestone.

The Truckee formation in the Lahontan Mountains is locally altered by silicification and clay-mineral alteration. The coarser tuff and tuffaceous sandstone beds have been especially prone to silicification, as in the hills half a mile south of Eagles House and on the 4,450-foot butte southwest of Rainbow Mountain. Locally the alteration has produced intricate patterns of varicolored bands known as wonderstone. A few of these deposits have been worked on a small scale for ornamental stone.

In the White Throne Mountains a thick series of well-indurated white to pale-gray and cream tuff, tuffaceous gravel, grit, and sand orerlies the Eagles House rhyolite and intertongues with the upper part of it (fig. $3 A$ ). It is correlated tentatively with the Truckee formation, although it does not resemble the bulk of this formation in the Lahontan Mountains. The larger clasts are almost entirely pumiceous rhyolite, pumice, and some felsitic rhyolite; a few basalt or andesite fragments generally are present, and locally make up as much as 25 percent of the rock (fig. $3 B$ ). Sorting is generally poor to lacking and bedding crude to indistinct, suggesting aerial or mudflow deposition, although some better sorted and stratified beds suggest reworking by streams. The beds are tilted $30^{\circ}$ to locally $70^{\circ}$ and commonly are closely faulted. Poorly. exposed white tuff and diatomite, which are considered the upper part of the Truckee formation, locally overlie these sediments on the west side of the White Throne Mountains, and thicken westward into the Desert Mountains.

The Truckee formation has not been identified in the Bunejug and Cocoon Mountains, but the tuffaceous zones in the lower unit of the Bunejug formation (p. 14) there may correlate with it. Zone 6 in the type section of the Bunejug formation (table 10, section 54) particularly resembles the Truckee formation in the Lahontan and White Throne Mountains: moreover, mafic pyroclastic matter is a widespread minor constituent of the Truckee in the White Throne Mountains, attesting to contemporaneous nearby andesitic and (or) basaltic volcanism. G. A. Thompson (1956) reported intertonguing between the Truckee formation and both rhyolitic and mafic flows in the Virginia City, Nev., quadrangle.

Several of the deeper wells in the basin interior may have penetrated the Truckee formation, but the available $\operatorname{logs}$ are too crude to permit reliable correlation.

The poor exposures, deformation, and erosion of the Truckee formation make estimation of its thickness difficult. In the Lahontan Mountains probably more than 400 feet, and in the White Throne Mountains probably at least 500 feet, are exposed.

Age and correlation.-The Truckee formation is generally unfossiliferous. Fossil leaves were collected from a single locality on Rainbow Mountain, and snails were taken from three localities in the eastern Lahon$\tan$ Mountains in the middle and upper parts of the formation, but these collections were too poorly preserved to be determinable as to species.

King (1878, p. 415) believed the Truckee to be Miocene in age at its type locality, Fossil Hill, in the Hot Springs (Kaw-soh) Mountains 25 miles northwest of Fallon, but Yen (1950) and MacDonald (1950) considered these beds to be Pliocene, and Axelrod (1950) determined them to be early Pliocene. Sediments referred to this formation are widespread in northwestern Nevada. Fossils indicate that their age is early Pliocene, but they were deposited in separate basins of differing structural histories and may not correlate exactly from basin to basin. Further study may show that in some areas they include beds as old as late Miocene. In general, they underlie the andesites and basalts of Pliocene (and possibly early Pleistocene) age that cap many of the mountains, and overlie earlier volcanics. In places however, beds of the Truckee intertongue with either or both the underlying and overlying volcanic rocks. (Gianella, 1936, p. 73; Thompson, 1956 , p. 55,56 , and oral communication, 1952).

Fossil florula from the Truckee formation at several localities west of the Carson Desert have been interpreted as early Pliocene by Axelrod (1950, and in Thompson, 1956, p. 56). Calkins reported (1944, p. 23) that K. E. Lohman studied the diatoms and R. W. Chaney the fossil leaves in the Truckee formation in Long Valley, 7 miles northeast of Virginia City, and agreed that these beds date from near the MiocenePliocene boundary. Yen (1950) determined that mollusks from near White Plains (Huxley Station) siding, 27 miles north of Fallon, were Pliocene.

\section{BUNEJUG FORMATION}

The most extensively exposed hard-rock unit is a series of basalts and andesites overlying the Truckee 

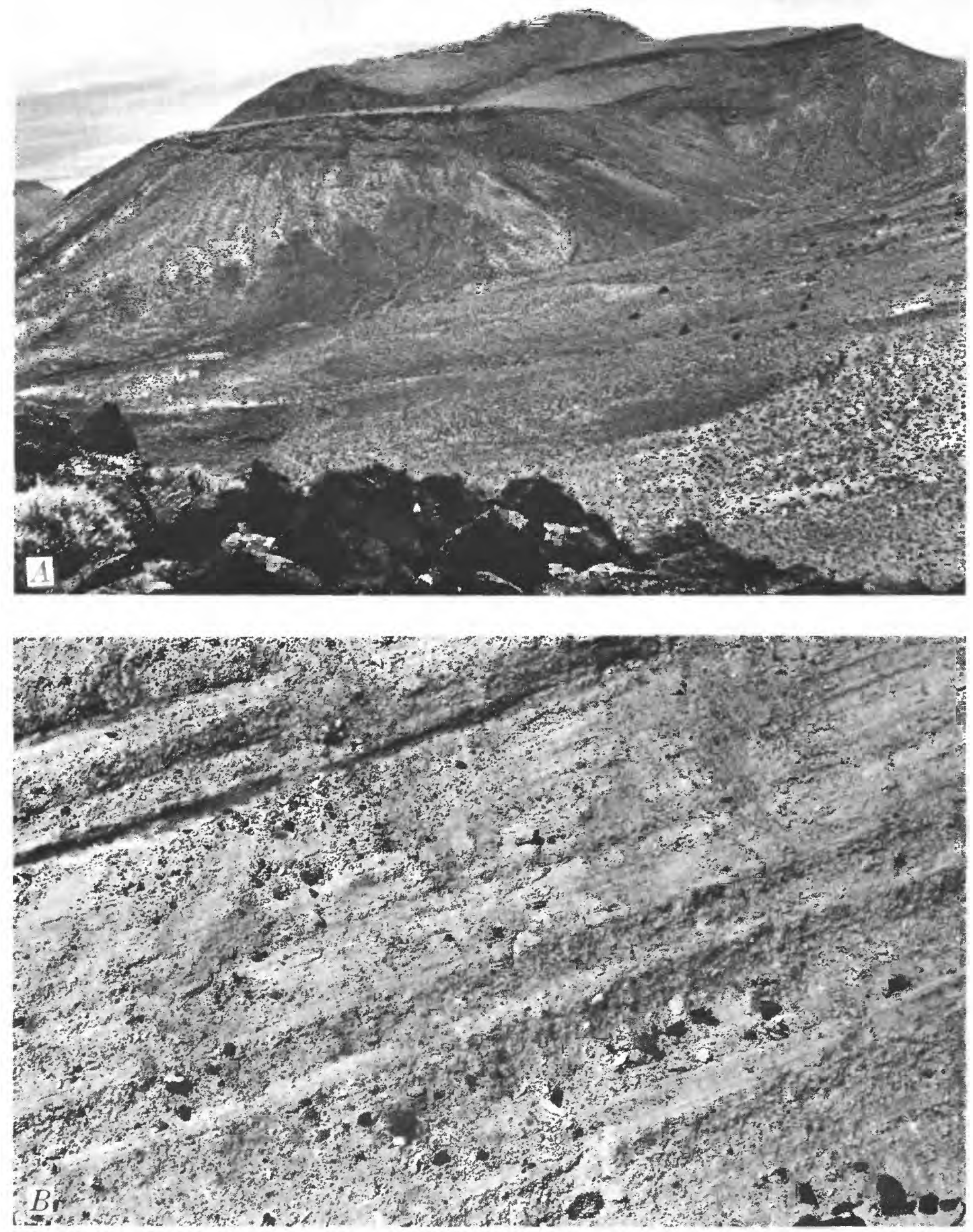

Figvre 3.-A, Eroded cappings of basalt of Bunejug formation, unconformable on Truckee formation. Lavas (dark) of Bunejug formation are exposerl near summits of far ridges and in forewround; elsewhere Truckee formation (light colored) is exposed (except where locally mantled by colluvium). Central White Throne Mountains. $B$, Pumiceous sand and gravel of Truckef formation. typical of this formation in White Throne Mountains. Dark fragnents are mainly talus from Bunejug formation, although a few are malic lava in place. 
formation. It is here named the Bunejug formation, after the Bunejug Mountains, in which it is well exposed The type locality is the west face of the 4,886foot mountain in the south-central Bunejug Mountains, secs. 33 and 34, T. 17 N., R. 30 E. (table 11, section 54T). The formation is Pliocene and possibly early Pleistocene in age.

These lavas form extensive relatively flat-lying to moderately tilted cappings, 50 to 650 feet thick, that rest on erosion surfaces of several hundred feet of local relief and commonly with pronounced angular unconformity on the Truckee formation and older rocks (fig. $3 A$ ). In spite of the initial relief and the faulting and tilting during the early part of Bunejug deposition ( $p$. 15 , the depositional surface on which the youngest flows were laid had generally low relief. This formation generally is much less closely faulted than the Truckee.

Many feeder dikes and a few vents have been identified. The dikes are most abundant along the major zones of post-Truckee early-Bunejug faulting (p. 15). The vents are circular to irregular, steep walled, have fillings of dense lava (volcanic plugs) or chaotic agglomerate of scoriaceous varicolored basalt, and are commonly intruded by dikes. They range in diameter from 200 to 2,000 feet; the largest is in the Cocoon Mountains at the south edge of the map area. The formation is thickest where dikes and vents are most numerous and commonly is absent where they are lacking. Some highlands where the lavas of the Bunejug are now very thin or absent probably were at altitudes too great to be inundated, for example in the Eagles House-Wyemaha Valley-Rainbow Mountain area.

The lavas in the lower part of the formation-the lower unit-are much more variable in texture and color than those of the upper part. They range from black to light gray, greenish gray, and red, pink, and purple; from dense to highly scoriaceous; and from glassy (obsidian and perlite) to porphyritic with 5 to 25 percent phenocrysts. Their groundmass generally is aphanitic to fine grained, but a few are medium grained and sugary textured. Some flows exhibit a strong platy contorted structure that resembles bedding but generally does not parallel flow margins. Individual flows are from several feet to more than 40 feet thick. Single flows or lava zones commonly cannot be traced more than 1 or 2 miles, even where good exposures occur. This lower unit is locally absent, but as much as 400 feet is exposed in the Bunejug and Cocoon Mountains, about 250 feet in the Sehoo and Eetza Mountains, and somewhat less in the White Throne Mountains and the Stillwater Range.
The lower unit has considerable interbedded tuff in the Bunejug and Cocoon Mountains, where three tuffaceous zones aggregate as much as 20 percent of the total section. They consist of tuff, tuff breccia, and some tuffaceous sand and gravel that is commonly pumiceous to some degree. The lowermost zone, near the middle of the exposed lower unit (unit 7 in section $53 \mathrm{~T}$, unit 6 in section $54 \mathrm{~T}$, and unit 8 in section $57 \mathrm{~T}$, table 10 ) is the thickest (15-50 ft thick), most persistent, and lightest colored; its upper part is mostly reddish to pink, tan, and orange, and its lower part is mostly white to light. Silicic flows are locally interbedded with it in the northern Bunejug Mountains. The upper two tuffaceous zones, several feet to 25 feet thick and locally absent, are light red, pink, tan, and gray. Locally in the Cocoon Mountains a thin fourth zone lies between the upper two and the lowermost zone. The tuffaceous zones may represent tongues of the Truckee formation, but this cannot be proved.

The upper part of the Bunejug formation-the upper unit-is entirely olivine basalt. Most flows are 10 to 15 feet thick, black and dark gray to locally red and purple, generally vesicular, and have scoriaceous tops and bottoms; most have small phenocrysts of plagioclase and olivine. Locally the flows are separated by discontinuous beds a few feet thick of basaltic tuff and tuff breccia (or rarely of basaltic gravel and sand), which are red, red brown, purple, and black. This unit ranges in thickness from less than 50 to about 150 feet and is more extensive than the lower unit. In places a small angular unconformity separates it from the lower unit; elsewhere the passage between the two units is gradational, via interbedding, and is conformable.

Age and correlation.-The Bunejug formation has yielded no fossils, hence its age can only be inferred. Because the Truckee formation is early Pliocene and the lower unit Bunejug possibly interfingers with and overlies it, the Bunejug formation is considered to be Pliocene, perhaps ranging to early Pleistocene in its upper part.

Andesites and basalts are widespread in western Nevada; they resemble the Bunejug formation in lithology and have stratigraphic relations similar to the Truckee formation or sedimentary units more or less correlative with the Truckee. The lower unit of the Bunejug may correlate with the Lousetown formation and perhaps the Knickerbocker andesite in the Virginia City quadrangle (Thompson, 1956, p. 57-58); the upper unit of the Bunejug might correlate in part with the McClellan Peak olivine basalt in the same quadrangle. Thompson inferred that these units range in age from Pliocene to Pleistocene. 


\section{STRUCTURAL FEATURES}

High-angle normal faulting dominated the Cenozoic deformation. The older Tertiary rocks are more faulted than the younger Tertiary rocks, indicating several ages of Tertiary faulting. Relatively few of the older faults are exposed, however; most exposed faults that cut the hard rock units are of post-Bunejug pre-Paiute age and hence of Quaternary, and perhaps late Pliocene age.

\section{PRE-TRUCKFE FAULTS}

The basalt of Rainbow Mountain is the oldest and most faulted and altered rock unit. The old faults are difficult to identify specifically, and their displacements are uncertain owing to several episodes of reactivation. The abundance of steep faults of the N. $15^{\circ} \mathrm{E}$., due north, and N. $15^{\circ}-25^{\circ} \mathrm{W}$. sets and their sparsity elsewhere suggests that these sets were dominant between the deposition of the basalt of Rainbow Mountain and of the overlying dacite. They form an intricate mesh of intersecting and bifurcating shears generally less than 200 feet apart; these have broken the basalt into narrow homoclinal blocks that mostly dip westward at angles of $15^{\circ}$ to $70^{\circ}$, generally $35^{\circ}$ and $60^{\circ}$. Although most of these faults are small and discontinuous, some have been traced for 1 or 2 miles. Also apparently of the same age, but very subordinate, are small shears trending roughly east-west.

The dacite of Rainbow Mountain is much less faulted and altered than the underlying basalt, and the Eagles House rhyolite and Truckee formation are even less deformed and altered. Many of these faults must be of pre-Truckee age, but no evidence for their specific age was recognized.

\section{FAULTS OF POST-TRUCKEE AND EARLY BUNEJUG AGE}

Most of the Truckee formation is closely sheared and moderately tilted by high-angle normal faults, and these faults are generally much more numerous and the tilting greater than in the Bunejug formation. Where the lower unit of the Bunejug formation is absent, a pronounced angular unconformity generally separates the -upper unit of this formation from the Truckee, and where the lower unit of the Bunejug is thick, this unit is more faulted and tilted than the upper one. The intra-Bunejug faulting of the lower unit may have been synchronous with faulting dated as post-Truckee pre-Bunejug where the lower unit is missing.

In the Lahontan and White Throne Mountains, this faulting has broken much of the Truckee formation into a giant breccia. The faults are high angle and normal, and generally have only a few feet or few inches of individual displacement, although a few have scores or hundreds of feet displacement. They have produced widespread homoclinal tilting, commonly $15^{\circ}$ to $40^{\circ}$ and rarely more than $50^{\circ}$, which generally is opposite to the dip of the faults, resulting in much repetition of beds. Striae and grooves on the fault surfaces generally have steep plunges, showing that displacements were mainly dip slip. Most faults trend north and northeast in the eastern Lahontan Mountains but northwest and west in the White Throne Mountains.

Wyemaha Valley, the Eagles House area, Rainbow Mountain, and the pass between Rainbow Mountain and the Stillwater Range apparently were all elevated by the post-Truckee pre-Bunejug deformation; these areas are structurally higher than adjoining parts of the Lahontan Mountains, and the stratigraphy and structure of the Bunejug formation suggest that lavas of that formation never appreciably inundated them. A zone of intra-Bunejug faulting along the northwestern side of the Lahontan Mountains is indicated by at least two volcanic vents, numerous feeder dikes, and local minor shears in the lower part of the Bunejug formation. In the Rainbow Mountains the larger faults of this age trend mainly due north to N. $50^{\circ} \mathrm{E}$. and are exceptionally long and straight.

In the Bunejug and Cocoon Mountains, faulting of this age moderately tilted the lower part of the Bunejug formation into a homocline. The faulting was penecontemporaneous with deposition as shown by increasing displacement of the faults and the increasing dip of the fault blocks, downward in the section. The faults trend mainly northward in the Bunejug Mountains, but diverge widely in the Cocoon Mountains. Displacements range from a few feet to locally several hundred feet. Some of the faults seem to be related to volcanic centers.

\section{STRUCTURAL FEATURES OF POST-BUNEJUG PRE-PAIUTE AGE}

\section{BASIN-AND-RANGE FAULTS}

\section{GENERAL FEATURES}

Most of the bedrock faults mapped are of post-Bunejug but pre-Paiute age. They displace the Bunejug formation (including the upper unit where present), yet they do not extend into the overlying Paiute formation and may be largely or entirely of Quaternary age.

The post-Bunejug pre-Paiute faults apparently record a climax of basin-and-range deformation separate from that of post-Truckee and early Bunejug faults. Faults of intra-Bunejug age are practically restricted to the lower (andesitic and basaltic) part of the Bunejug formation; the upper (olivine basalt) part gener- 
ally is affected only by post-Bunejug faults, and in places the two parts are separated by an angular unconformity.

The post-Bunejug pre-Paiute faults exposed in the mountains have throws generally less than 100 feet (commonly only a few feet) and little or no gouge, brecciatied areas, or hydrothermally altered zones. The faults are normal and steep, rarely dipping less than $60^{\circ}$. Tiny reverse faults, seen as side shears associated with larger normal faults, are rare. Displacements are almost entirely dip slip, as shown by grooves, striae, and alinement of fault traces. Strikes are very diverse, particularly from one mountain area to another, but the predominant strikes are N. $30^{\circ}$ E. to N. $20^{\circ} \mathrm{W}$.; other prominent faults strike N. $50^{\circ}-60^{\circ} \mathrm{E}$. The diverse strikes may reflect the position of the Carson Lake quadrangle being just south of the boundary between dominantly northward- and northeastwardtrending and dominantly northwestward-trending ranges and basins (Spurr, 1901, p. 258; Gianella and Callaghan, 1934, p. 3, 18).

Much larger faults and fault zones of post-Bunejug pre-Paiute age border highlands that abut the basins. These marginal faults are largely concealed by detritus, but their existence and dominant role in outlining the present basins and ranges are inferred from the following criteria: (a) Bedrock structure is sharply truncated along the mountain fronts; (b) the mountain fronts are prominent scarps having fairly straight alinement and faceted spurs in places; (c) the marginal faults are exposed locally, they parallel the local mountain front, have large displacement and commonly wide zones of shattering, and some show hydrothermal alteration; (d) airborne magnetometer traverses show sharp magnetic discontinuities one-half to 3 miles basinward from the mountain fronts. ${ }^{1}$ These discontinuities suggest abrupt thickening of the sedimentary fill at probable fault scarps.

A rough measure of maximum displacement of the marginal faults is the difference in altitude between the highest beds of the Bunejug formation adjoining a mountain front and the bedrock floor of the basin adjoining this front. Total displacements of more than 1,500 feet, without allowance for possible warping, are indicated along the north and west sides of the White Throne, Bunejug, and Lahontan Mountains, and 4,000 feet or more bet ween the Stillwater Lakes and the Stillwater Range. Two criteria show that most of the marginal displacement occurred in post-Bunejug pre-Paiute time: (1) The geomorphology of the highlands, espe-

\footnotetext{
${ }^{1}$ Unpublished data on file from about 12 airborne magnetometer reconnaissance traverses, spaced 1 to 12 miles apart on an irregular east-west and north-south grid across the Carson Desert, made in July 1948 by the U.S. Geological Survey.
}

cially the stage of development of the mountain canyons and pediments (p. 22), shows that the last main interval of basin-and-range deformation took place after deposition of the Bunejug formation but long before deposition of the Paiute formation; and (2) well logs suggest deep fill of Quaternary sediments of pre-Lake Lahontan age on the basin sides of the buried fault scarps.

Two main episodes of faulting apparently took place, separated by a period of relative stability, in post-Bunejug pre-Paiute time. The pediments at the edges of the mountains are younger than some marginal faults and commonly extend across these faults without displacement; howerer, these pediments terminate basinward in fault scarps (p. 17), indicating that largescale faulting occurred after the pediments were formed. As the pediments all lie at about the same general level, the faults that are younger than the pediments probably depressed the basins without selective uplift of individual highland areas. Similar largescale faulting, both older and younger than the pediments, has been noted on the nortluwest side of the central Humboldt Range (Jenney, 1935, p. 58, 65-68) and on the east sides of the Virginia-Flowery Range and Pine Nut Mountains (G. A. Thompson, oral communication, 1950).

\section{FAULTING IN SPECIFIC AREAS}

In the Bunejug Mountains, faults of post-Bunejug pre-Paiute age are particularly numerous. Most strike between $\mathrm{N} .10^{\circ} \mathrm{W}$. and $\mathrm{N}$. $25^{\circ} \mathrm{E}$., are vertical or dip steeply westward, and cut the Bunejug formation into slivers a few feet to a third of a mile wide. Most of the fault blocks have been tilted eastward so that the upper flows of the Bunejug dip $5^{\circ}$ to $35^{\circ} \mathrm{E}$., but blocks on the east side of the mountains have been tilted westward. The west and east edges of the mountains are particularly closely sheared and in places hydrothermally altered, suggesting that the mountains are a compound horst.

The Cocoon Mountains have a haphazard fault pattern but northward-striking faults are dominant. Most of the larger faults curve considerably, and many radiate from volcanic centers. The faults in the interior are relatively small and commonly less than 50 feet and rarely more than 100 feet in throw; only along the northeast and east sides has much tilting occurred, and this tilting was eastward. Marginal faults are concealed except for a few poor exposures north of 4,645 peak.

The White Throne Mountains probably are bounded by marginal faults of post-Bunejug pre-Paiute age, and a few faults are exposed on the east front and pedi- 
ment. No mappable interior faults were found, although this area was much affected by post-Truckee and intra-Bunejug faulting (p. 15).

At Rainbow Mountain, post-Bunejug pre-Paiute faulting is difficult to assess because the Bunejug formation is absent, but the faults separating the horsts (undelain by the basalt and dacite of Rainbow Mountain) from the grabens (underlain by the Truckee formation) probably had much of their displacement at this time. Their displacement probably was accompanied by minor adjustment of earlier faults in the interiors of the main blocks. From the eastern edge of Sehoo Mountain to the vicinity of Eagles House is a closely faulted area. Probably only part of the movement is of post-Bunejug pre-Paiute age. Relatively little tilting has taken place. Few faults are exposed in the rest of the Lahontan Mountains, owing to the general cover of surficial sediments.

In the small part of the Stillwater Range that extends into the map area most of the faults strike northward although a few strike west. Displacements are down on the west and south, and little tilting has occurred.

\section{CONFIGURATION OF THE BEDROCK FLOOR OF THE BASIN}

A little information on the configuration of the bedrock (pre-Quaternary) floor of the basin is available from reconnaissance airborne magnetometer traverses (p. 16, 22) and well logs. Several areas near the edges of the basin are known to be underlain by pediments cut on Tertiary rocks and buried by Paiute and younger deposits. Abrupt magnetic discontinuities and deepening of the younger sedimentary fill suggest that the pediments generally terminate basinward in buried fault scarps. In places the buried pediments extend basinward for considerable distances before they are thus terminated-about 2 miles from the front of the Desert Mountains, 1 to $21 / 2$ miles from the Dead Camel Mountains, and 1 to 3 miles from the east front of the Cocoon Mountains.

The magnetometer traverses also show, however, that in a few places the bedrock plunges rapidly to depth along buried scarps close to present mountain fronts, and here pediments are almost lacking. The only examples in the map area are along the north front of the White Throne Mountains and the west front of the Bunejug Mountains, where buried scarps are associated with the Wildcat fault zone.

For the interiors of the basins, the magnetometer data suggests that the bedrock floor lies not closer than several hundred feet below the surface, and well $\log \mathrm{s}$ suggest that it ranges in depth from several hundred to more than 1,000 feet. The floor seems to be deepest beneath the southern and southeastern part of the main basin (Carson Lake, Stillwater Slough, and Stillwater Lakes areas). For example, an oil-test well two-thirds of a mile northwest of the north end of Rainbow Mountain penetrated basalt at about 58 feet, yet a 500 -foot well $4 \frac{1}{2}$ miles to the northwest, in sec. 28 , T. 19 N., R. 30 E., penetrated only unconsolidated sediments, and a well at the Naval Auxiliary Air Station is reported to have been drilled to almost 1,700 feet in unconsolidated sediments.

\section{QUATERNARY STRATIGRAPHY METHODS OF STUDY}

Early research on the late Quaternary lakes in the Western United States centered on their geomorphic features, such as beach terraces, spits, bars, and deltas, rather than on their stratigraphy. In the present study, and in recent studies in the Lake Bonneville area by Hunt and others (1953) and by Bissell (1963) the emphasis has been on stratigraphy rather than geomorphology; stratigraphic units have been mapped instead of landforms, although lacustrine and subaerial landforms were studied. Shore terraces, bars, and spits show lake maximums and stillstands, but the morphologic relations of these landforms alone, even those of the younger lakes, generally do not give full information on either their order of development or other details of lake history, such as the lower limits of lake recessions.

The stratigraphic record, however, is difficult to study. Many of the units are difficult to trace and correlate because of their rapid facies changes and their lithologic resemblances; good marker horizons and diagnostic fossils are scarce. The unconsolidated deposits slump readily and good exposures are sparse and discontinuous. Highland washes rarely expose more than 50 feet of section, and commonly only 5 to 20 feet; moreover, they flow so infrequently that their banks are badly slumped. The lowlands are mostly devoid of stream dissection, but the scarps of deflation basins locally reveal fairly thick sections. The extensive systems of irrigation and drainage canals, locally as deep as 15 feet, have made particularly good and continuous exposures.

The techniques used for this study are similar to those used in general geologic mapping: separating the deposits into mappable (rock-stratigraphic) units, determining the superposition of the units, mapping their contacts, and noting lateral and vertical changes in lithology, as well as the altitude range and stratigraphic range of unconformities. Because fossils are meager and relatively nondiagnostic, the deposits had to be studied as essentially nonfossiliferous rocks. 
Gullies, canals, and other places exposing the best deep sections were given principal attention. The stratigraphic units were then mapped across intervening areas where surficial materials are poorly exposed, mostly by using soil texture; this was occasionally augmented by auger holes a foot to several feet deep. In the more detailed mapping of the Carson Lake and Stillwater quadrangles and the special larger scale maps, the surficial deposits below the highest shoreline of Lake Lahontan were differentiated only where they consisted of reworked or transported (introduced) sediment differing distinctively in texture, composition, or bedding from underlying material and were at least a foot thick. In the less detailed mapping of the Fallon and Soda Lake quadrangles, however, only deposits more than 3 feet thick, below the highest shoreline, were generally mapped; moreover, the widespread cover of eolian sand of Turupah and Fallon age was ignored in order to simplify map patterns. However, in places deposits thinner than 1 or 3 feet were mapped if they were deemed particularly significant. Above the highest shoreline, in all the quadrangles, a 5 -foot minimum thickness was used in mapping the surficial sediments to minimize the colluvial cover, and because these subaerial sediments were considered less significant for deciphering the late Quaternary history.

Several hundred stratigraphic sections were measured in order to record the thickness, areal extent, and facies changes and superposition of the stratigraphic units. Information on buried deposits was obtained by augering, trenching, or digging pits; 150 auger holes were put down by hand to depths ranging from 6 to 30 feet in Carson Sink and other areas of poor exposures. All available driller's logs of wells were collected. Selected stratigraphic sections, soil-profile sections, and well logs are given in tables 10,11 , and 12 ; many others have been published separately (Morrison, 1958a).

The pattern of Lake Lahontan and younger stratigraphy and the history were pieced together from many key localities by mapping a large area. They probably could not have been worked out reliably by merely measuring isolated stratigraphic sections without mapping the deposits in the intervening areas.

Analysis of lake history.-The primary objective of the study was to decipher the lake history. The lake maximums and main stillstands were determined by mapping the deposits of each significant lake cycle and observing their relations to shore features. The lake minimums-much more difficult to determine-were found by noting subaerial features developed upon or intercalated between lake sediments, and tracing those of a given age to their lowest altitude limit. These subaerial features include alluvial, colluvial, or eolian sediments, unconformities representing subaerial erosion, soils, mud cracks, sand dikes and dikelets, root casts and molds, land-plant and marsh-plant remains in place, and land-animal remains and coprolites. Subaerial exposure, or at least a major drop in lake level, also is suggested by shallow-water deposits such as lake gravel or algal tufa interbedded with deep-lake sediments. It is critical to determine the vertical range of each unconformity or recessional unit; merely identifying one at a single altitude commonly gives no indication whether it records a break between major cycles or represents only a minor fluctuation.

Unfortunately, many exposures do not show the breaks between different lake sedimentation cycles clearly; commonly the breaks appear as diastems because many represent short intervals without much erosion, subaerial sedimentation, or soil development, and, in places, even without much change in lake sedimentation above and below. Tracing the subaerial features is more difficult toward the lower parts of the basin so the lake minimums were at least as low as determined, but may have been still lower.

\section{STRATIGRAPHIC USAGE}

The Quaternary sediments are differentiated into three main rock-stratigraphic units-Paiute formation, Lahontan Valley group, and Fallon formation-by gross differences in lithology. The Paiute formation consists of alluvium and colluvium older than Lake Lahontan. The Lahontan Valley group is a succession of intertonguing deep-lake, subaerial, and shallow-lake sediments of Lake Lahontan and early post-Lake Lahontan age. The Fallon formation contains the younger subaerial sediments and the shallow-lake deposits with which they intertongue.

The formations are differentiated by general vertical and lateral differences in lithology. One formation may be characterized by deep-lake sediments; another, intertonguing with it, may be entirely subaerial, and still another, overlying the first, may consist of intertonguing subaerial and shallow-lake sediments (fig. 1, pl. 12). The formations are rock-stratigraphic units, differentiated on the basis of lithologic character and not on either inferred climate during deposition or assumed age differences. Their main differences are between lake and subaerial sediment relations and the formations are thus most clearly differentiated where lake beds occur. Above the lake maximums the formations are differentiated by lithology of alluvial gravel, by proportions of alluvium and eolian sand, and by soils, but their boundaries commonly are less sharply defined.

Two formations of the Lahontan Valley group, the Sehoo and Indian Lakes formations, as well as the 
Fallon formation, are subdivided on the basis of their intertonguing lake and subaerial deposits. In the Sehoo and Indian Lakes formations individual members or tongues are single units of either lacustrine or subaerial sediments; in the Fallon formation several intertonguing lacustrine and subaerial units comprise each member, and the individual units are locally differentiated as lacustrine or interlacustrine (pls. 3, 4; fig. 25 ). The members, tongues, and units generally are not mapped but are designated in many of the stratigraphic sections in table 10.

Each formation, member, or unit includes several lithofacies. The lacustrine units generally consist of lake gravel, sand, silt, clay, tufa, and locally a little volcanic ash. The subaerial units contain alluvium and colluvium, eolian sand, and locally, shallow-lake sediments. On the quadrangle geologic maps, subdivision of formations generally is by lithofacies alone.

\section{SOIIS}

\section{DEFINITION AND GENERAL FEATURES}

Soils of several different ages are associated with the late Quaternary sediments. The term "soil" is restricted in this report to mean a profile of weathering, or soil profile, consisting of a layer of material that is discernibly weathered by chemical and physical surficial agencies. The soils range in degree from very weak to very strong, and each maintains the same degree of development relative to the others wherever it occurs. The more strongly developed ones have vertical zonation into soil horizons, corresponding to the zonal and intrazonal soils of soil scientists, but the weakly developed soils have only incipient indistinct zonation. Zonal soils are those whose most important characteristics reflect the influence of climatic and biologic factors acting on well-drained parent material for a long time, whereas intrazonal soils owe their distinguishing characteristics less to climatic, biologic, and time factors than to the effects of parent material or topography, which locally may overbalance the effects of other soilforming factors.

Each soil maintains a consistent age relation to the associated deposits, akin to a rock-stratigraphic unit, and is defined on the basis of this relation. It is given a local geographic name independent of the soil names of agronomic soil scientists, and a type locality is designated. The soils are not mapped, but are designated in many of the stratigraphic sections in table 10, and are described in detail in the soil-profile sections in table 11.

In the area mapped for this study, five soils were found to be sufficiently well developed and widespread to merit formal names (fig. 4). They are the following:

Cocoon soil.- - the oldest and most strongly developed and occurs on deposits as young as the uppermost beds of alluvial gravel and colluvium of the Paiute formation $\left(a-b\right.$, relict occurrence; $b-b^{\prime}$, buried occurrence, fig. 4).

Churchill soil.-strongly developed, intermediate in development between the Cocoon and Toyeh soils. It lies on deposits as young as the uppermost subaerial beds of the Wyemaha formation ( $b-c$, relict occurrence; $c-c^{\prime}$, buried occurrence, fig. 4). The soil is not evident where it developed on relicts of the Cocoon soil because of the stronger development of the Cocoon.

Harmon School soil.-very weakly developed and therefore occurs only as a buried profile because in relict occurrences it is masked by the more strongly developed Toyeh soil.

Toyeh soil.-moderately developed compared with the other soils. It occurs on deposits as young as the uppermost beds of the Turupah formation $(c-d$, relict occurrence; $d$ - $d^{\prime}$, buried occurrence, fig. 4 ). It is not evident where it developed on relicts of the Churchill and Cocoon soils owing to the stronger development of these soils.

" $L$ " Drain soil.-found on deposits as young as the second lake unit of the Fallon formation, and so weakly developed that it is not distinguishable where it

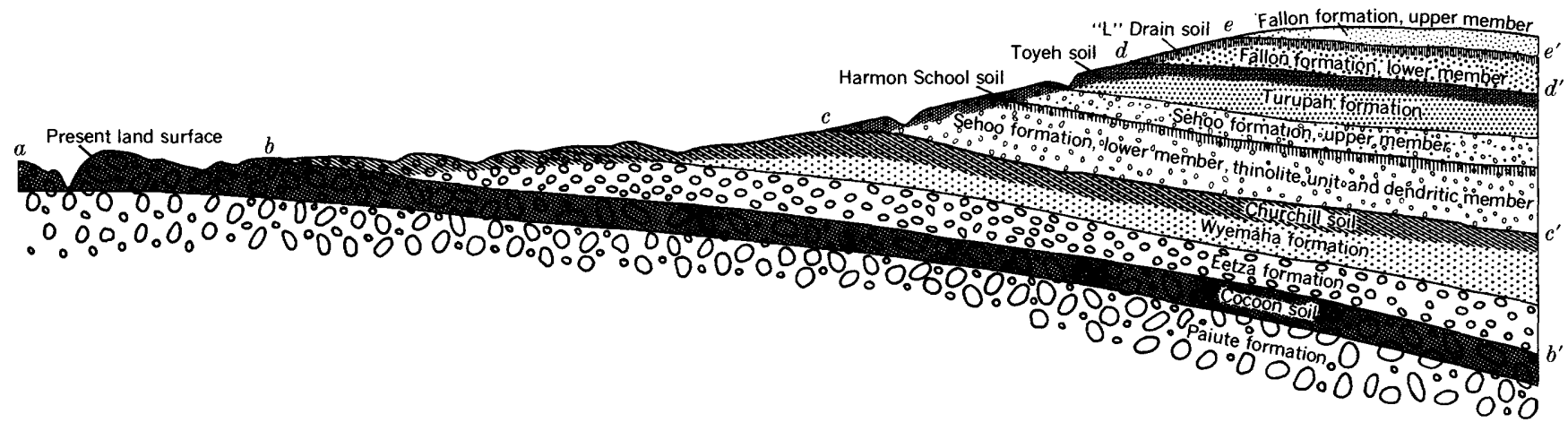

Figure 4.-Diagram showing the age and stratigraphic relations of the five main (named) late Quaternary soils in the Carson Desert area. 
developed on relicts of the older soil, $(d-e$, relict occurrence; $e-e^{\prime}$, buried occurrence, fig. 4 ).

These five soils are the only ones with true soil profiles that have been recognized. The deposits that are intermediate in age between each of these soils are devoid of any evidence of coeval soil development, except for two horizons of incipient weathering (extremely weak soil development), one of thinolite recessionage and the other of middle Eetza age.

Each soil occurs both where it has been buried by younger deposits, and where it has remained at the land surface ever since its formation. The former is called a buried soil, and the latter a relict soil. The more strongly developed soils of the Carson Desert area generally show almost no secondary profile modification, other than local erosion and, in the case of the older soils, development of a younger soil horizon in the upper several inches of relict occurrences (p. 25, 40). The absence of secondary modification in the main part of the soil profile is shown by the profiles of uneroded relict soils being virtually the same as buried ones of the same soil. The weak soils, however, except the very youngest, are preserved only in buried occurrences; persumably they were altered during subsequent intervals of stronger soil development wherever they were relict.

The stratigraphic record shows that each soil is of a distinct geologic age, separated from the other soils by intervals of negligible soil formation. The geologic age of a soil is determined from that of the youngest deposit or erosion surface on which it is formed and that of the oldest deposit which overlies it, in as many different environments as possible.

The more strongly developed soils are among the most useful stratigraphic markers in the late Quaternary succession. Once the geologic age of such a soil has been determined, relict occurrences can be used with assurance as well as buried ones; relict occurrences are by far the most common and therefore the most useful. Soils are practically time-parallel (p. 109), and hence they are useful for time-stratigraphic correlation and may be used to define time-stratigraphic units. Stratigraphic attributes of soils have been discussed by Richmond and-Frye (1957).

\section{SOIL PROFILE}

A soil is characterized by zonation into soil horizons; the aggregate of the several horizons is called the soil profile. The horizons differ in color, texture, chemical and mineralogic composition, structure, and other properties, and are more sharply differentiated with increasing development of the soil.

The following three horizons occur in the soils of the Carson Desert area :
Vesicular (A) horizon.-The uppermost or A horizon is not the usual type found in soils of more humid areas; here it consists of sandy loam, loam, or pebbly sandy loam that is partly leached of clay and carbonate and has a vesicular structure. This horizon, called the vesicular horizon, is lacking in the older soils. It has a sharp lower boundary.

Oxide (B) horizon.-The middle horizon, here called the oxide horizon, is characterized by enrichment of clay and iron oxide and generally by low or absent carbonate. It is present in all the soils, although in the weaker ones it is incipiently developed. The $\mathbf{B}_{\mathrm{ca}}$ or $\mathbf{B}_{3}$ subhorizon is marked by accumulation of calcium carbonate in the lower part of the $\mathrm{B}$ horizon, and is transitional into $\mathrm{C}_{\mathrm{ca}}$ horizon.

Calcareous $\left(\mathrm{C}_{\mathrm{ca}}\right)$ horizon.-The lowermost true soil horizon, here called the calcareous or $\mathrm{C}_{\mathrm{ca}}$ horizon, contains an accumulation of calcium carbonate. It occurs in all the soils of this area.

Below the true soil profile are the $\mathrm{C}$ and $\mathrm{D}$ horizons of the soil scientists; these designations are not used in this report. The $\mathrm{C}$ horizon refers to unconsolidated mantle, either residual or transported, which may be the parent material for the soil and the $\mathrm{D}$ horizon is bedrock.

In the Carson Desert area each soil horizon has similar general characteristics wherever it occurs, although in soils of different age it commonly differs considerably in degree of development.

Good profiles of the older soils are restricted to locations exceptionally well protected from erosion. The upper horizons are particularly liable to erosion, but the $\mathrm{C}_{\mathrm{ca}}$ horizon is resistant where well developed.

\section{CLASSIFICATION}

Soil scientists in the United States classify soils into several categories. These are, in order of decreasing magnitude: soil order, great soil group, soil family, soil series, and soil type. In this report soils are classified according to great soil group, in preference to the smaller categories of soil series and soil type which are the fundamental working units of the soil scientist. The great soil group is most useful for the surficial geologist because it stresses general profile characteristics, rather than minor differences caused by differences in parent material and local factors. The minor differences generally are irrelevant to the differentiation and use of soils as rock-stratigraphic markers.

In an area having considerable range in climate and vegetation, a soil of a given geologic age may pass from one great soil group into others; such changes are considered to be changes in facies of a soil. The climatic range within the Carson Desert area is small, however, 
and each soil has only a single facies; however some of the younger soils have a special local facies developed in poorly drained areas.

\section{DESCRIPTIVE TERMINOLOGY}

Soil descriptions in this report accord with present practice by soil scientists in the U.S. Department of Agriculture, as outlined in the Soil Survey Manual (U.S. Dept. Agriculture, 1951). As the terminology is unfamiliar to many geologists, the definitions are summarized below.

Color.-Soil colors refer to the dry soil, using the Munsell soil-color system of notation and nomenclature (U.S. Dept. Agriculture, 1951, p. 194-203). Many Munsell soil-color names differ-although symbols are the same-from standard Munsell color names that are used in this report for describing geologic deposits other than soils.

Texture.-Soil texture refers to the proportions of clay, silt, and sand below $2 \mathrm{~mm}$ in diameter. The principal textural classes, based on the relative proportion of each, are: sand, loamy sand, sandy loam, loam, silt loam, clay loam and clay (U.S. Dept. Agriculture, 1951, p. 205-223).

Structure.-Soil structure is an especially diagnostic property. It refers to the shape of aggregates of primary soil particles, called peds, which are separated from each other by surfaces of weakness. Their size, shape, and distinctness vary widely with different genetic factors. The following terms describe the soilstructure types of the Carson Desert area: Columnar, arranged in vertical prisms, having small horizontal dimensions compared to their vertical dimensions; vertical faces well defined and vertices angular; rounded caps. Prismatic, same as columnar but without rounded caps. Platy, relatively thin horizontal plates. Blocky, blocklike; blocks or polyhedrons having plane or curving surfaces. Granular, hard or soft but cohesive small aggregates, angular or rounded. Vesicular, characterized by spherical or egg-shaped cavities one sixty-fourth to more than one-fourth inch in diameter. Dimensions of the structure types are indicated by adjectives such as very fine, fine, medium, coarse, and very coarse, following the specifications in the Soil Survey Manual (U.S. Dept. of Agriculture, 1951). Degree of development of these types is denoted by the terms "strong," "moderate," "weak," and "structureless" (or "massive," if coherent; "single-grain," if incoherent). Thus, "moderate medium columnar" means "moderately developed columns of medium (20 to $50 \mathrm{~mm}$ across) size."

Consistence.-Soil consistence is the resistance to separation or deformation of individual peds, and is described in separate terms for the standard moisture states: dry, moist, and wet. Degrees of consistence are determined: (a) when dry, by resistance to granulation between thumb and fingers, and are described as loose, soft, slightly hard, hard, and very hard; (b) when moist, by resistance to rupture between thumb and fingers, described as loose, very friable, firm, very firm, and extremely firm; and (c) when wet, by pressing between thumb and fingers, described as nonsticky, slightly sticky, sticky, and very sticky, and as nonplastic, slightly plastic, plastic, and very plastic.

Boundaries.-Boundaries between soil horizons are described in terms of width as: abrupt, less than 1 inch wide; clear, 1 to $21 / 2$ inches wide; gradual, $21 / 2$ to 5 inches wide; and diffuse, more than 5 inches wide. Soil boundaries are described in terms of shape as: smooth, nearly a plane; wavy or undulating, pockets are wider than their depth; irregular, pockets are deeper than their width; and broken, parts of the horizon are unconnected with other parts.

General terms for degrees of soil development.-Relative degrees of soil development are expressed in this report as very strong, strong, moderate, weak, very weak, and incipient. These designations express the sum of different characteristics of the whole profilethickness, color, structure, consistence, and $\mathrm{pH}$-and accumulation of clay, iron oxide, and calcium carbonate in individual horizons. Differences in degree of development are evalauted by comparing soils developed on parent material that is similar in both lithology and permeability, on flat or gentle well-drained slopes.

One of the best indices of degree of soil development in the Carson Desert area, both for buried and relict soils, is the thickness and density of calcium carbonate accumulation in the $\mathrm{C}_{\mathrm{ca}}$ horizon. This horizon commonly is a better index than the oxide horizon; the vesicular horizon is not a reliable index.

\section{GREAT SOIL GROUPS}

Calcic Brown soils. - Calcic Brown soils are zonal soils characterized by an $\mathbf{A}$ horizon, 0 to 8 inches thick, partly humus and partly mineral, brown to brownish gray, slightly acidic to neutral, and partly leached of clay and sesquioxides; a B horizon of clay and sesquioxide accumulation, 4 to 24 inches thick, that is brown, prismatic to blocky, and slightly acidic to mildly alkaline; and a $\mathrm{C}_{\mathrm{ca}}$ horizon of carbonate accumulation, $1 \frac{1}{2} 2$ to locally 10 feet thick, that is pale brownish gray to nearly white, weakly blocky to massive, moderately to strongly alkaline, and gradational into parent material. The two most strongly developed soils in the Carson Desert area, the Cocoon and Churchill soils, have all the characteristics of Calcic Brown soils except that the $\mathrm{A}$ horizon 
in relict occurrences resembles the vesicular horizon of Gray Desert soils in being pale gray, lacking humus, and having a strong vesicular structure. This horizon probably is younger than the rest of the profile and not properly a part of the Cocoon or Churchill soils.

Gray Desert Soils.-Gray Desert soils as designated by the U.S. Department of Agriculture vary widely from the type soil of this great soil group, the Portneuf silt loam (Lapham, 1932), and overlap into the Calcic Brown, Sierozem, and Red Desert great soil groups.

A restricted definition is used here: A Gray Desert soil is generally intrazonal but in places is zonal, and it is characterized by: (a) an A horizon 0 to 4 inches thick, of nonhumic sandy to clayey loam, light gray to light brown, weakly to strongly alkaline, friable, generally weakly to moderately platy but locally columnar, and locally vesicular at the top or throughout; locally a layer of gravel, generally only one pebble thick, overlies this horizon; (b) a $\mathrm{B}$ horizon having a slight to moderate accumulation of clay and sesquioxides, 4 to 18 inches thick, brownish gray to light brown, slightly hard to hard, blocky to prismatic, neutral to mildly alkaline, and generally gradational into the $\mathrm{C}_{\mathrm{ca}}$ horizon; and (c) a $\mathrm{C}_{\mathrm{ca}}$ horizon of calcium carbonate accumulation (and locally some calcium sulfate accumulation), which has less segregated calcium carbonate than Calcic Brown soils; it is 6 to 30 inches thick, light brown to pale gray, weakly blocky to massive single grain, mildly to strongly alkaline, and gradational into parent material.

Variants toward Solonchak and Solonetz soils.-The Gray Desert soils of the Carson Desert locally vary toward Solonchak and Solonetz soils, which are saline soils formed where parent material is saline or where poor drainage has caused salt accumulation. The vesicular horizon generally is absent; instead, these soils have a white to light-gray salty crust in places, about a quarter of an inch thick, underlain by half an inch to several inches of light- to dark-gray highly aggregated (flocculated) clay loam or clay having a strong fine-granular structure and loose to fluffy consistence (termed "self-rising ground" where well developed). The B horizon is darker gray or brown gray, moderately compact, and has a structure ranging from strong columnar (Solonetz soil) to granular (Solonchak soil). The $\mathrm{C}_{\mathrm{ca}}$ horizon generally has only moderate calcium carbonate concentration and is only several inches thick.

\section{PRE-LAKE LAHONTAN EROSIONAL FEATURES}

The highlands had almost exactly their present shapes when they were first inundated by Lake Lahon- tan. This is evident not merely from comparing the terrain above and below the highest shoreline, but also from the contact at the base of the earliest sediments of Lake Lahontan (Eetza formation), which follows a topography differing only in minor details from the present one. Pre-Bunejug erosion surfaces are exposed only locally where the mantle of younger Cenozoic rocks has been eroded. The oldest erosion surface manifest in the present topography is one of late-mature relief; it is younger than the upper part of the Bunejug formation and older than most of the pre-Paiute faulting, of which traces are locally preserved on the summit plateaus (fig. $3 A$ ). This surface seems to be better preserved in nearby higher mountains east, south, and west of the area. The major erosional features of the present highland topography postdate this surface, and hence are largely or entirely of Quaternary age.

Pediments.-The earliest well-preserved extensive erosion surfaces are pediments that have been cut on Tertiary rocks at the edges of mountains. The pediments are mostly buried by younger deposits, but their upper fringes are locally exposed in washes. Their buried extent is revealed by well $\operatorname{logs}$ and by magnetometer traverses (p. 17). They developed in postBunejug pre-Paiute time during an interval between two major climaxes of basin-and-range faulting ( $p$. 16). Within the map area only one general level of pediments is discernible, but elsewhere in the region two or more levels have been identified (Jenney, 1935, p. 65-67; Thompson, 1956, p. 69).

The largest areas of partly exposed pediments are Wyemaha Valley and the saddles between Sehoo Mountain and Rainbow Mountain, and between Rainbow Mountain and the Stillwater Range. Their lower altitude with respect to the bordering mountains is probably due largely to differential erosion of the soft Truckee formation.

Canyons.-The valleys in the mountains are in the early mature or, locally, the youthful stage of development. They dissect the Bunejug formation, but terrace remnants, veneered with alluvial gravel of the Paiute formation, show that they were cut nearly to their present depth by Paiute time. That they had attained virtually their present forms before the advent of Lake Lahontan is shown by the ubiquitous colluvium of the Paiute formation, bearing the Cocoon soil, on the valley slopes above the highest shoreline, as well as by the topographic relations of the contact at the base of the Eetza formation. Post-Paiute erosion has amounted to generally less than 30 feet of downcutting of the stream channels and to negligible modification of the valiey slopes by mass-wasting. 


\section{PRE-LAKE LAHONTAN QUATERNARY STRATIGRAPHY}

BASALT OF RATTLESNAKT HILI

Basalt of probable Quaternary age forms the small volcano, Rattlesnake Hill, 1 mile northeast of Fallon. Rattlesnake Hill is a much-eroded cone 1 mile in diameter and 200 feet high; it has several summits that surround a shallow crater 1,000 feet in diameter at the center of the cone. The basalt is largely covered by Lake Lahontan sediments and young eolian sand. It is mostly black to dark-gray flows that appear to have low outward dips where they are best exposed, as in the quarries on the northwestern side of the hill. The crater is underlain by locally exposed basaltic agglomerate-a brick-red to deep-purple-red chaotic mass of vesicular basalt blocks of all sizes in a finer matrix and some blocks of sandstone and shale. Pebbles of rhyolite, mafic porphyry, and quartzite or chert also occur sparingly in the gravel of Lake Lahontan derived from this area; their only possible source is from the basalt, indicating that they were carried up from below in the vent.

The basalt flows probably were extruded by quiet eruptions from the Rattlesnake Hill vent. The agglomerate fills a later vent, which was drilled up through these flows during a final phase of explosive volcanism.

Caliche, typical of the lower part of the Cocoon soil (p. 25, 28), is locally preserved in the uppermost parts of the flows and agglomerate in spite of several wave erosions by Lake Lahontan; its presence suggests that the basalt of Rattlesnake Hill is older than the Cocoon soil. The earliest unit of Lake Lahontan sediments, the Eetza formation, also rests on the basalt, showing it to be older than Lake Lahontan.

Seven wells near Rattlesnake Hill penetrated basalt or reported basalt beneath several hundred feet of Quaternary sediments. Some of these wells may have penetrated buried tongues of basalt of Rattlesnake Hill, but others may have penetrated buried hills of the Bunejug formation. The basalt generally is a good aquifer and yields water of better quality than other aquifers in the area. Of these 7 wells, 2 , located $1 \frac{1}{2}$ miles southwest of the center of Rattlesnake Hill, penetrated basalt at 455 feet; they are used for Fallon's municipal water supply. Another well, about 2 miles southeast, supplies the Naval Auxiliary Lir Station; the other wells are $31 / 2$ miles west, 2 miles southeast, $41 / 2$ miles northnortheast, and $t$ miles east-southeast of Rattlesnake Hill.
PRE-LAKE LAHONTAN LACUSTRINE SEDIMENTS

Pre-Lake Lahontan Lacustrine sediments of Quaternary (?) age are exposed in a gully at the lower edge of the pediment between Sehoo Mountain and Rainbow Mountain, in the SE $1 / 4$ SE $1 / 4$ sec. 12 , T. 18 N., R. 31 E., at an altitude of about 4,020 feet. They consist of as much as 20 feet of partly consolidated lacustrine sand, gravelly sand, and gravel (section 30, table 10) locally showing caliche that is typical of the Cocoon soil; these disconformably underlie sediments of Lake Lahontan. These beds intertongue with gravel to the north that dips about $45^{\circ} \mathrm{SE}$. and is part of a lake spit or bar. The beds are unfossiliferous and their age uncertain. Clearly older than Lake Lahontan and the Cocoon soil, they also may be older than the Paiute formation, for they are better consolidated than is usual for this formation. They are less consolidated and less tuffaceous than most Truckee deposits and contain pebbles of Truckee lithology, so they are probably of post-Truckee age. The exposure is in a fault sliver downfaulted, with respect to the Truckee, to the south.

This exposure is the only one of shore deposits or shore features of a lake older than Lake Lahontan, despite the fact that the McGee and Sherwin Glaciers in the Sierra Nevada were greater than the Tahoe and Tioga ones that are correlative with Lake Lahontan cycles (p.110 and pl.12).

\section{PAIUTE FORMATION}

General features.-The youngest sedimentary unit of pre-Lake Lahontan age has been named the Paiute formation (Morrison, 1961a) after Paiute Wash; it consists of alluvial gravel and colluvium. This formation is exposed in the mountains and on the piedmonts bordering the basins. It overlies the Bunejug formation and older rocks with pronounced unconformity, and is overlain by the Eetza formation of the Lahontan Valley group with slight or no disconformity. Intermediate in age between it and the Eetza formation, however, is the Cocoon soil, which has a very strongly developed soil profile, and hence is an excellent marker for differentiating the pre-Lake Lahontan deposits from the Lahontan Valley group.

The type locality of the Paiute formation is Paiute Wash (sec. 8, T. 16 N., R. 31 E.) on the piedmont northeast of the Cocoon Mountains. The banks of this wash expose well the stratigraphic relations of alluvial gravel of this formation to the Cocoon soil, Bunejug formation, and Lahontan Valley group (section 56, table 10).

Alluvial gravel.-The bulk of the Paiute formation is alluvial-fan gravel, which is exposed locally in the mountain valleys and on the piedmonts. Generally the 
exposures are above altitudes of 4,040 feet, although on the eastern piedmont of the Cocoon Mountains, bordering Fourmile Flat, the Paiute is exposed as low as 3,960 feet. Below the high shore of Lake Lahontan this gravel is mostly buried by younger sediments; a few washes-notably Paiute Wash-have cut through this veneer. In the mountain canyons only rare tiny patches of the gravel have survived later erosion; more extensive deposits are preserved in a few mountain basins, such as those in the central Bunejug and northern Cocoon Mountains. Maximum exposed thickness of the gravel is about 40 feet, along the middle part of Paiute Wash. Much greater thicknesses, locally more than 150 feet, are exposed along the western side of the Stillwater Range a few miles northeast of the map area.

The distribution and general shape of the alluvial fans of this gravel commonly can be distinguished, despite widespread cover by younger sediments, by their transverse profiles, local exposures, and size-these fans are much larger than any of the younger ones. There is no evidence of significant dissection of their surfaces prior to the first rise of Lake Lahontan, nor are there significant unconformities or interbedded soil profiles in their gravel; the exposed part of the gravel is interpreted as recording only a single interval of alluviation.

Throughout the map area the alluvial gravel is boulder to coarse pebble gravel, poorly sorted, torrentially bedded, angular to subangular, and is characteristic of steep- to moderate-gradient ephemeral washes in arid regions. The rock fragments are the rocks in the drainage area-chiefly basalt and andesite. Generally the proportion of interstitial fines is low and these are mostly silt and clay rather than sand. This gravel typically is less sandy than the younger alluvial gravels, especially that of the Wyemaha formation (p. 36).

Colluvium.-Thin sheets of colluvium of Paiute age veneer many mountain slopes above the high shore of Lake Lahontan. Below the high shore this colluvium is rare, having been reworked by waves. In the mountain valleys the colluvium grades into and interfingers with alluvial gravel of the Paiute formation. It is grouped with the alluvium on the geologic maps.

The colluvium is mainly solifluction mantle, creep mantle, and local slide rock (talus) beneath cliffs. It extensively conceals the bedrock in areas back from the frontal scarps of the mountains, resulting in smoothly rounded slopes. It is a foot to several feet thick on the mountainsides, but commonly thickens to more than 5 or even 10 feet near the base of the slopes and in saddles. Only deposits more than 5 feet thick are mapped. This thickening evidently is due to slow downslope movement, for crude stratification and shingle structure that parallel the land surface are common. Generally the colluvium is strongly cemented by calcium carbonate, which is inferred to be the $\mathrm{C}_{\text {ca }}$ horizon of the Cocoon soil. This colluvium commonly is mantled by 1 or 2 feet of younger colluvium, which is not differentiated on the geologic map.

Age.-The Paiute formation seems to be of late preLake Lahontan Quaternary age because no large unconformities or lithologic discontinuities are evident in the exposed formation, the Cocoon soil is conformable upon it, and that soil is immediately older than the earliest deposits of Lake Lahontan (Eetza formation).

\section{BURIED PRE-LAKE IAHONTAN QUATERNARY} SEDIMENTS

Logs are available for many deep wells drilled in the lowlands, but correlations with exposed deposits are not reliable below the top few feet. Equivalents of the Paiute formation doubtless exist in the subsurface of the basin interior, and even older Quaternary sediments may be present, but they cannot be identified in any of the logs.

\section{Cocoon sorn}

\section{GENERAI FEATURES AND RELATIONS}

The youngest exposed beds of alluvium and colluvium of the Paiute formation bear a soil that has a very strongly developed profile. This soil also occurs locally on older rocks, but not on younger ones. It directly underlies the earliest unit of the Lahontan Valley group (Eetza formation) and thus postdates the Paiute formation and predates the Lahontan Valley group.

This soil is called the Cocoon soil, after its type locality at the edge of the Cocoon Mountains. It is a Calcic Brown soil and much more strongly developed than any younger soils of the area. In degree of development it resembles the pre-Wisconsin paleosol in the Rocky Mountain region (Hunt and Sokoloff, 1950). The Cocoon soil is the same as the soil that was called (Morrison, 1961a) the pre-Lake Lahontan soil.

The Cocoon soil is exposed only in the highlands. Above the highest shore of Lake Lahontan it is widely exposed, commonly as relicts, both on bedrock and on alluvium and colluvium of the Paiute formation. Below the highest shore it is rarely exposed, having been eroded by waves in all but the most sheltered locations or buried by younger sediment; exposures of such buried occurrences have been found at altitudes as low as 4,000 feet.

Type locality.-The type locality of the Cocoon soil is Paiute Wash, which heads in the Cocoon Mountains. Here this soil is developed on alluvial gravel at the type locality of the Paiute formation (section 56, table 10 ), beneath gravel of the Eetza formation and eolian 
sand of the Wyemaha formation. It is exposed for more than 1 mile upstream along the main wash and its tributaries, and is particularly well exposed in the basin south of the 4,645-foot summit in the Cocoon Mountains (fig. 5). Unfortunately this locality does not illustrate the full profile of the soil, for the $\mathrm{B}$ horizon is partly or completely eroded; only the $\mathrm{C}_{\mathrm{ca}}$ horizon is well preserved.

\section{PROFILE CHARACTERISTICS}

In the area mapped, the Cocoon soil is exposed in a comparatively small altitude range, from about 4,000 to 5,300 feet. It is a Calcic Brown soil throughout this altitude range; the soil shows no appreciable difference in development on similar parent material and comparatively small variation on different parent material.

The complete undisturbed profile of this soil is rarely seen; most exposures have been eroded by waves, wind, slope wash, or mass wasting. The original A horizon was nowhere found; the B (oxide) horizon generally is partly or entirely eroded or reworked. The $\mathrm{C}_{\mathrm{ca}}$ (calcareous) horizon is least eroded, largely because of its resistant heavy cementation. The calcareous horizon is sufficiently diagnostic to distinguish the Cocoon from the younger less strongly developed soils.

The character of the upper part of the Cocoon soil is well shown in two profiles, 58S and 59S (table 11), from shallow pits dug on the summit plateau of the White Throne Mountains (fig. 6A).

The sites were carefully selected to be as free as possible from younger erosion and deposition; they are on nearly level broad ridge crests. The parent material is colluvium-solifluction mantle and creep mantle- of the Paiute formation, which overlies basalt of the Bunejug formation. The pits were dug only a few inches into the basalt, so they did not reach the bottom of the calcareous horizon.

These and other relict occurrences of the Cocoon soil commonly show, at the top, a vesicular horizon of 1 to 40 inches of pale pinkish-gray sandy loam or loam with highly vesicular structure, which resembles the vesicular horizon of the Toyeh soil (p. 79). Because this horizon commonly crosscuts the oxide horizon of the Cocoon soil and because it is not present in buried occurrences, it is believed to be younger than the Cocoon soil and not part of its original profile.

The oxide horizon of the Cocoon soil is preserved only on flat or gently sloping surfaces that are well protected from erosion; elsewhere it is generally eroded or disturbed by creep and solifluction. It consists of reddishbrown to brown clay loam and is appreciably more clayey than the parent material, typically stony, granu- lar to subangular blocky to prismatic in structure, slightly hard to hard when dry, and slightly plastic when wet. Most of the larger rock fragments are peripherally stained and softened but have fresh interiors; relatively few are soft throughout. This horizon is generally only a few inches, and at most about 1 foot thick. In the lower several inches, transitional into the $\mathrm{C}_{\mathrm{ca}}$ horizon (the $\mathrm{B}_{\mathrm{ca}}$ subhorizon) the color lightens, the clay content decreases, and in places small segregations of calcium carbonate are present. The oxide horizon has more clay, is darker and redder, and has a greater maximum thickness than the oxide horizons of any of the younger soils.

The calcareous $\left(\mathrm{C}_{\mathrm{ca}}\right)$ horizon is the most prominent and resistant part of the Cocoon soil, commonly being the only part preserved (fig. $6 B$ ). It is characterized by strong calcium carbonate (caliche) concentration in coatings, veinlets, concretions, and disseminated particles, and consequently it is light pinkish gray to white. The caliche resembles some kinds of lithoid tufa of Lake Lahontan, but generally the caliche is whiter and has a more chalky or earthy luster. Thickness and intensity of development are influenced by the mineral composition and permeability of the parent material. Normal thickness is 4 to 8 feet; extreme range in thickness, 3 to 12 feet. The calcium carbonate concentration is strongest in the upper part of the horizon and gradually decreases downward. At some localities, the upper part commonly is crudely layered with alternating relatively pure and less pure calcium carbonate. In the purer layers the smaller rock particles are absent and the carbonate is interstitial between larger fragments, forming a breccia. This layering parallels the land surface that existed at the time the soil formed. The $\mathrm{C}_{c a}$ horizon acts as a caprock where gullies or washes have cut through it into underlying less coherent material.

No general differences in original profile characteristics can be discerned in comparing the $\mathrm{C}_{\mathrm{ca}}$ horizons of buried and relict occurrences of this soil with respect to properties that are readily observed in the fieldthickness, color, structure, consistence, general degree of calcium carbonate concentration, and field $\mathrm{pH}$. This suggests that subsequent soil-forming processes have not been sufficiently effective for long enough intervals to appreciably modify relict profiles of the $\mathrm{C}_{\mathrm{ra}}$ horizon.

This horizon varies little with differences in parent material, relative to the younger soils. Variations are largely due to differences in calcium content and permeability of the parent material. This horizon is very strongly developed on calcic rocks such as basalt, or sediment composed largely of it, and weakly developed on rhyolite (compare profiles 58 and 59 with profile 46 , in table 11). The calcareous horizon is thickest in 


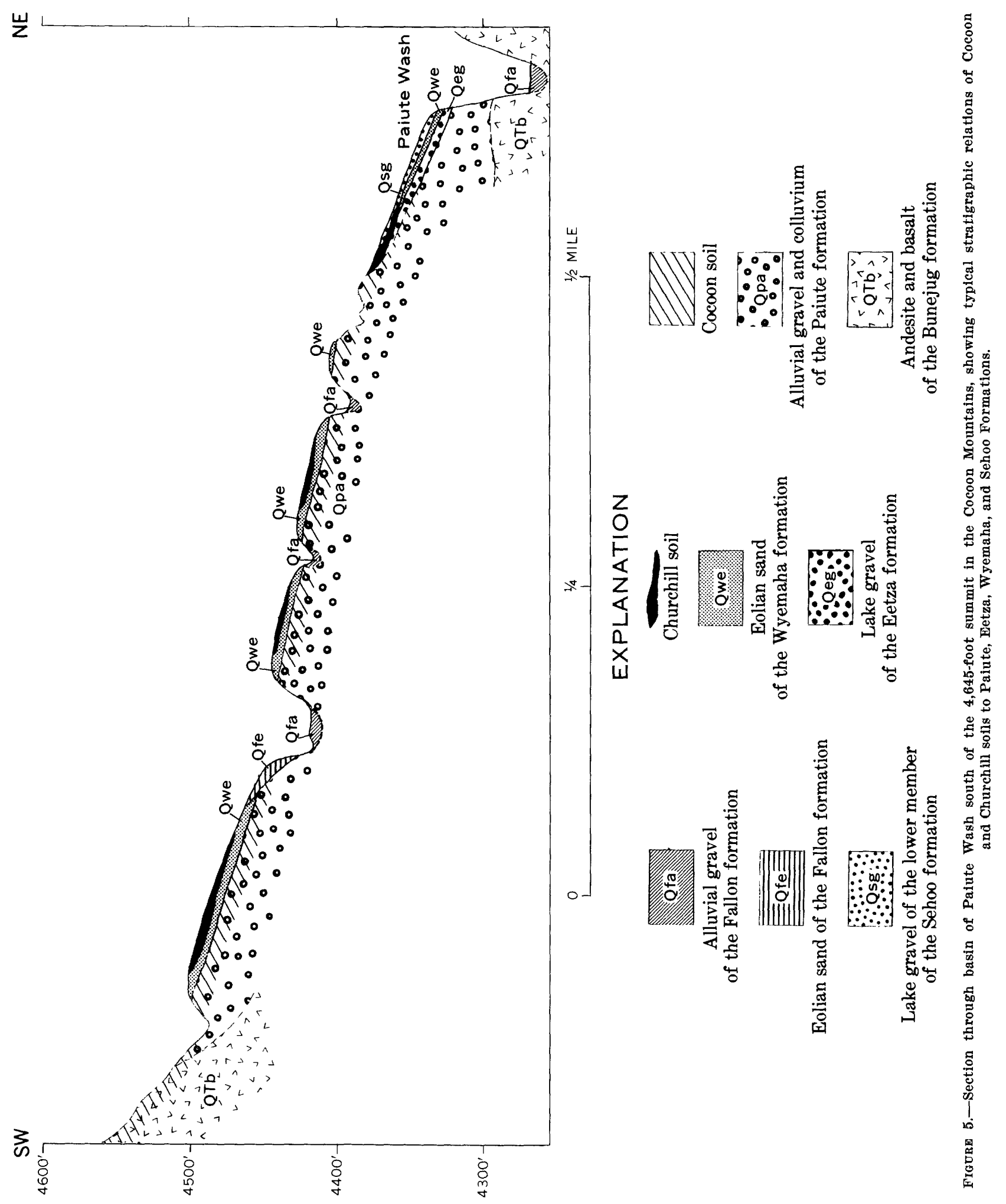



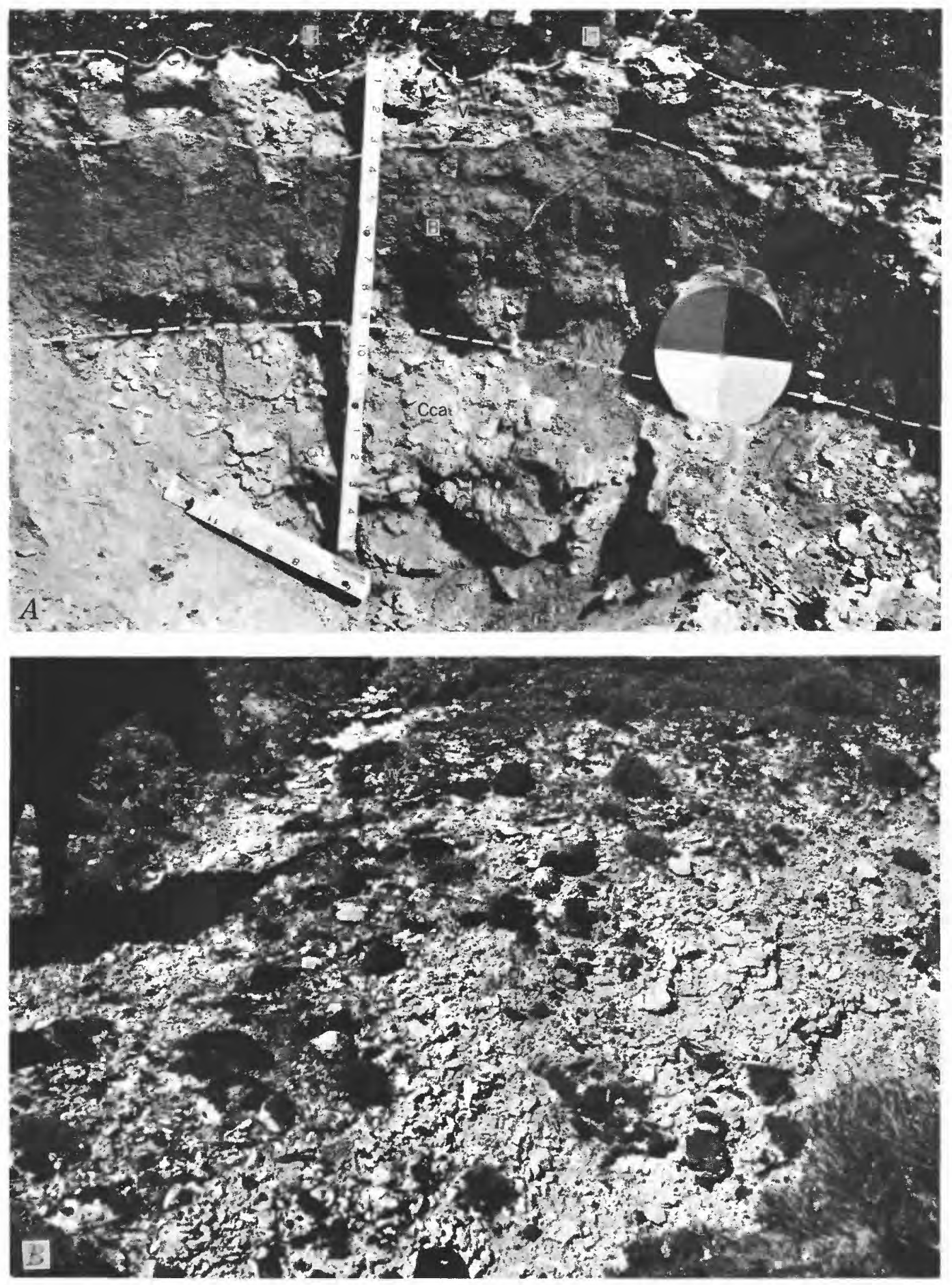

Figdre 6.-Cocoon soil. A, Well-preserved upper part of its profile, in pit on summit plateau of the White Throne Mountains (see soil profile 58S, table 11). Upper several inches form a vesicular horizon (V), overlain by lag gravel $(\mathrm{lg})$; both probably are younger than Cocoon soil. Remainder of exposure is true Cocoon soil, consisting of an upper oxide horizon (B) of reddish-brown clay loam, and a lower calcareous horizon (Cca), of pink to nearly white caliche hardpan (base not exposed). Formed on thin colluvium of Paiute formation over basalt of Bunejug formation. $B$, Typical exposure on sloping surfaces, showing only the resistant Cca horizon; the $B$ horizon has been eroded. Base of the Cca horizon is not exposed; its strong development is characteristic of that on calcic parent material (here colluvium of Paiute formation, derived from Bunejug formation). Stillwater Range, sec. 22 (unsurveyed), T. 18 N., R. 31 E. 
permeable material such as alluvial gravel, but the calcium carbonate is more dispersed. The horizon is thin but its caliche is especially concentrated where dense bedrock lies at shallow depth, as where it has formed in colluvium over basalt.

Influence of slope on profile characteristics.-The oxide horizon of the Cocoon soil is so poorly preserved on slopes that the effect of variations in slope on its original development is unknown. Differences in slope up to at least $30^{\circ}$ cause no discernible variations in original thickness or intensity of development of the $\mathrm{C}_{\mathrm{ca}}$ horizon.

Modification by erosion or disturbance is appreciable in at least 95 percent of the relict occurrences, but the cemented $\mathrm{C}_{\mathrm{ca}}$ horizon generally remains relatively undisturbed. Creep and solifluction have commonly churned new material into the oxide horizon to form colluvium, younger than the Cocoon soil, which thickens downslope. Slope is critical: on slopes of more than $10^{\circ}$ the $\mathrm{B}$ horizon is severely to completely eroded or reworked, and on slopes of more than $25^{\circ}$ the $\mathrm{C}_{\mathrm{ca}}$ horizon commonly is also appreciably eroded. Even on flat uplands where the profile is best preserved, the upper part of the oxide horizon in places shows evidence of having been somewhat eroded and disturbed.

\section{AGE}

The Cocoon soil is developed on the youngest beds of the Paiute formation; for example, at the apexes of pre-Lake Lahontan alluvial fans, where alluviation probably was active till the end of Paiute time. No soil has been observed at lower stratigraphic levels in the Paiute formation. The Cocoon soil (locally including the B horizon, somewhat eroded) is overlain in many places by the earliest gravels of Lake Lahontan, so it obviously is post-Paiute and pre-Eetza in age.

\section{LAHONTAN VALLEY GROUP}

Overlying the Cocoon soil and older units are lacustrine and subaerial sediments that record a succession of five deep-lake cycles alternating with intervals of partial or complete lake recession-these are the series of lake fluctuations that are Lake Lahontan in the sense that this name was used by Russell (1885). These sediments were named (Morrison, 1961a) the Lahontan Valley group after the term commonly used for the southern part of the Carson Desert. Lahontan Valley group replaces the name Lake Lahontan beds, which is here abandoned.

The Lahontan Valley group is subdivided into five formations - the Eetza, Wyemaha, Sehoo, Indian Lakes, and Turupah formations-on the basis of lithologic differences due to two major alternations, from mainly deep-lake to subaerial and shallow-lake sediments. Two formations, the Sehoo and Indian Lakes, are further subdivided. The Lahontan. Valley group overlies the Cocoon soil and underlies the moderately developed Toyeh soil (p. 78); intercalated with it is the strongly developed Churchill soil (p. 38-39) and two incipiently developed soils. The group is Pleistocene in age (Morrison and others, 1957 , p. 390).

\section{EETZA FORMATION}

GENERAL FEATURES

The Eetza formation, stratigraphically the lowest unit in the Lahontan Valley group, consists of deep-lake sediments that overlie the Cocoon soil and older units and that underlie the subaerial and shallow-lake sediments of the Wyemaha formation. It records the first deep-lake period of Lake Lahontan. The type locality of the Eetza is the upper one-eighth mile of the large southward-draining gulch in the western part of Eetza Mountain (SW1/4 sec. 21, T. 18 N., R. 30 E.) Here cobbly and bouldery lake gravel as much as 15 feet thick overlies the Bunejug formation and underlies the Wyemaha and Sehoo formations.

The Eetza formation is exposed only in the highlands, where it consists of lake gravel and minor amounts of lacustrine sand, clay, and tufa. It extends as high as the highest shoreline of Lake Lahontan - at an altitude of about 4,380 feet along the south margin of the Carson Desert-about 10 feet higher than the next younger main unit of deep-lake sediments, the Sehoo formation. The upper and lower boundaries are sharp and readily identifiable.

\section{LAKE GRAVEL}

Distribution, stratigraphic relations, and thickness.Lake gravel is the only lithofacies of the Eetza formation extensively exposed and is practically the only one associated with correlative shore features. It ranges from the highest shoreline of Lake Lahontan to as low as 3,920 feet in exposures along Wildcat scarp north of the White Throne Mountains, and at least as low as 3,890 feet altitude in the subsurface. It is extensively exposed above 4,000 feet on the mountain shores close to exposures of bedrock or Paiute formation, but generally it is concealed by younger sediment elsewhere.

This gravel rests either on bedrock or on alluvial gravel or colluvium of the Paiute formation, and generally is overlain by eolian sand of the Wyemaha formation or by gravel or sand of the Sehoo formation. The stratigraphic relations can be seen especially well at the following places: The type locality at Eetza Mountain; the saddle between Eetza Mountain and Sehoo Mountain (pls. 7, 8) ; the type locality of the Paiute forma- 
tion (p. 23); the reentrant west of the 4,645-foot peak at the northeast edge of Cocoon Mountain (section 55, table 10); and along many of the washes at the edge of the Stillwater Range within and adjacent to the Carson Lake quadrangle.

The gravel ranges in exposed thickness from less than 1 foot to rarely 90 feet; it normally is less than 20 feet. The thickest exposures are in the high-shore embankments along the north front of the Desert Mountains (fig. 7), in mountain reentrants where bars and spits were prominently developed, and in a few low-lying spits opened by gravel pits. In the thickest exposures the base of the gravel commonly is not exposed.

Lithology.-Gravel of the Eetza formation typically is boulder or cobble gravel; rarely is it pebble gravel. Almost everywhere it is the coarsest lake gravel of the Lahontan Valley group. The coarsest and best rounded gravel either is close to or directly overties outcrops of hard bedrock on mountain shores that were most exposed to strong wave action-particularly the north slopes of the Eetza, Sehoo, Bunejug, White Throne, and Desert Mountains. On these shores the boulders commonly are several feet in diameter, and sand and pebbles are minor constituents (fig. 8). Here also the gravel commonly is associated with prominent rock-cut features, such as wave-cut terraces, cliffs, caves, and small stacks. The roof of Hidden Cave in Eetza Mountain shows this type of deposit especially well: the gravel, cemented by lithoid tufa of this formation (table 5), is more than 20 feet thick and contains boulders as much as 5 feet in diameter. The rare exposures of pebble gravel are in the distal parts of spits and bay bars, away from hardrock outcrops.

On shores sheltered from strong waves, the gravel is finer and thinner. The waves commonly washed out the finer material of the colluvium and alluvial gravel of the Paiute formation, leaving a coarse lag concentrate 1 or 2 feet thick and so little reworked that the fragments are subrounded to subangular. Cut features are absent, and depositional features are only weakly developed, except locally. on lee shores adjacent to shores of strong wave action, where spill-over spits occur.

Generally the roundstones in this gravel are entirely andesite and basalt, the prevailing hard rocks of the highlands; locally they are rhyolite or silicified tuff.

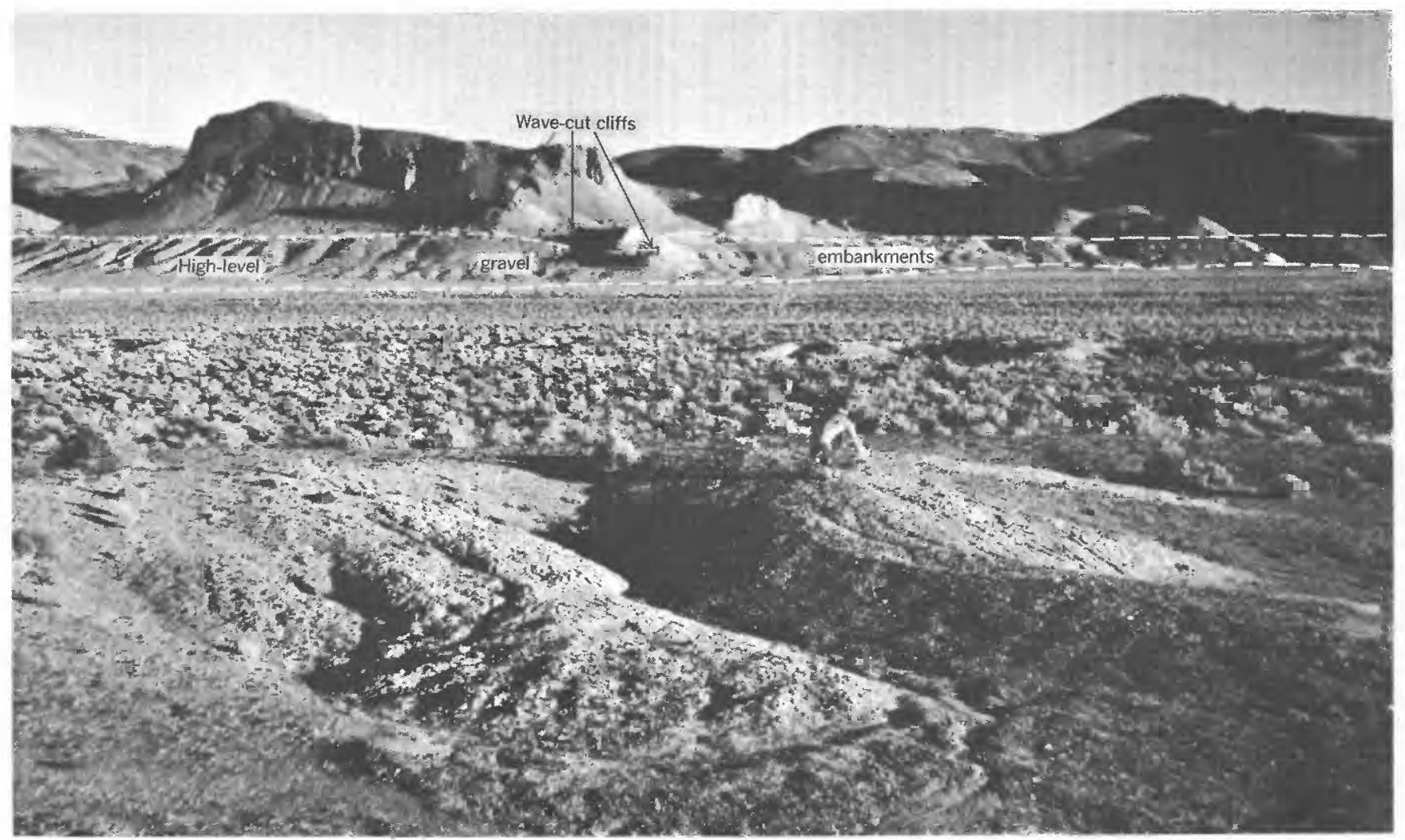

Figure 7.- Northern piedmont of Desert Mountains, showing exceptionally thick high-level embankments of gravel of Eetza formation and lower member of Sehoo formation, and locally prominent wave-cut cliffs. This shore faces directly north and was exposed to very strong waves, with fetches of 30 to 70 miles northwestward to northeastward during the higher levels of the Eetza and early Sehoo lakes.

Foreground shows clay of Sehoo formation, which grades rapidly upslope into gravel of this formation; this gravel mantles most of the piedmont up to the high-level embankments: 


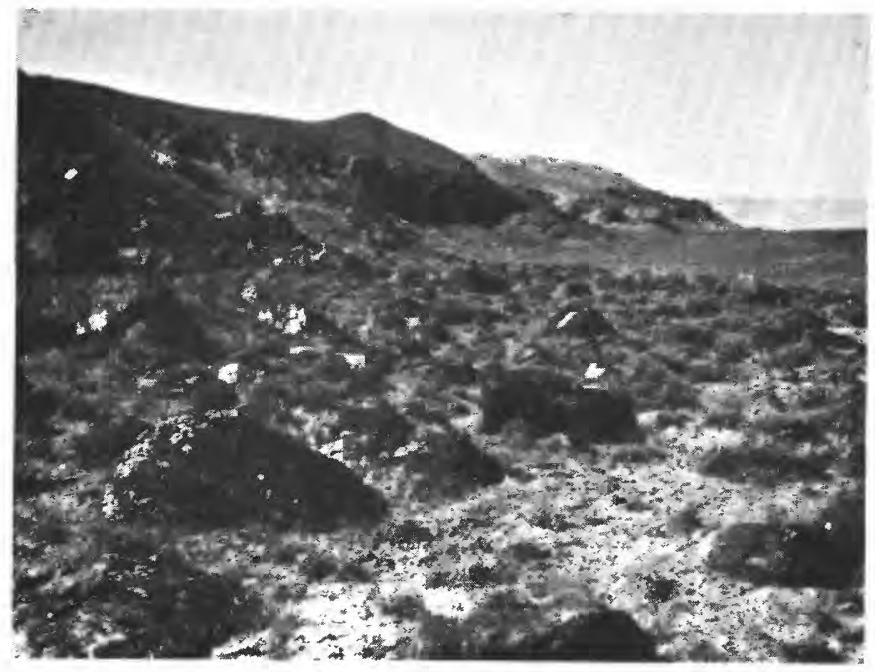

Figdre 8.-Bouldery gravel typical of the Eetza formation on mountain shores fronting upon the main basin and exposed to strong waves. Larger boulders are 3 to 6 feet in maximum dimension. Northeast edge of Desert Mountains, NW1/4 sec. 20 (unsurveyed), T. 16 N., R. 29 E., about 4,350 feet altitude (about 30 feet below the Lahontan beach). Bedrock is Eagles House rhyolite. The cliffs in background were partly wave cut during higher stands of the Eetza and early Sehoo lakes.

This gravel lacks distinctive tufas although locally it contains lithoid tufa in place or as waterworn fragments.

Commonly the lower parts of thick sections of the gravel are coarser than the upper parts; these coarser parts commonly make up the bulk of constructional shore terraces, spits, and bars of Eetza age and also are associated with rock-cut features of the main shorelines. In the thick gravel embankments along the north front of the Desert Mountains, the Eetza formation commonly has upper and lower gravel zones separated by a middle zone of sand, silt, and local gravel (section 60, table 10).

\section{SHORE FEATURES}

Gravel of the Eetza formation is associated with a series of shorelines developed during stillstands of Lake Lahontan. The visible shorelines are practically restricted to the steeper mountain slopes, as elsewhere they were buried by younger sediment. They are marked by wave-cut and dispositional shore terraces, spits, bars, and locally caves. These shorelines differ in degree of development because of differences in duration of the stillstands, in windstorm intensities, in exposure due to topography, and in erosional resistance of the shore material. Shore features bordering the main Carson Desert and facing north or west are most strongly developed.

The Lahontan beach.-The highest shoreline of Lake Lahontan, called the Lahontan beach by Russell (1885, p. 101), is at an altitude of about 4,380 feet along the south edge of the Carson Desert; the most accurate determinations were 4,382 feet at the VABM triangulation station on Eetza Mountain and 4,378 feet at Russell Spit (fig. $30 B$ ), about 515 feet above the lowest part of Carson Sink. Russell (1885, p. 101) deduced from the geomorphic relations of shore features that this shoreline formed during the second high-level period of the lake (Sehoo time of this report). The writer, however, believes that in the southern part of the Carson Desert it is of early Eetza age (p. 65), and that the highest level reached by the lake in Sehoo time is about 10 feet lower (fig. 9).

The Lahontan beach is a comparatively minor shoreline, although important in marking the boundary between subaerial and subaqueous sculpture (figs. 10, 11). It commonly is not visible on shores sheltered from waves; on exposed shores it is marked by beach terraces a few feet wide, and by small bay bars of gravel in some of the reentrants of the mountain slopes.

Lower shorelines.-Below the Lahontan beach, about 15 shorelines of Eetza age are marked by both rock-cut and depositional shore features, strongly to moderately developed (pl. 9), and 12 minor shorelines are marked by small gravel embankments without rock-cut features. The stronger shorelines probably formed mainly during early Eetza time, because the coarsest lake gravel of the Eetza formation, which is in the lower part of the section, rests directly on the wave-cut surfaces and makes up the bulk of the constructional features.

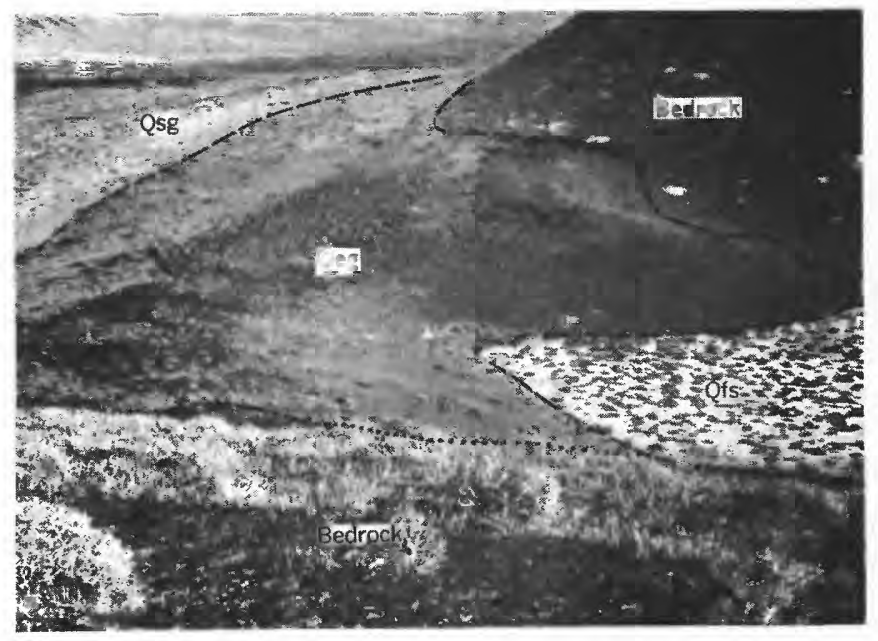

Frgure 9. -Relations of the highest shore of Lake Lahontan (Lahontan beach), which is of Eetza age, to the highest shore of the early Sehoo lake, as revealed by the shore deposits. Darker gravel (Qeg) is Eetza formation; lighter gravel (Qsg) is lower member of Sehoo formation; Qeg-Qsg contact is the highest shoreline of the early Sehoo lake; whitish area at right (Qfs) is young playa sediment. About one-third of a mile southeast of Russell Spit of the northeast edge of Desert Mountains. 


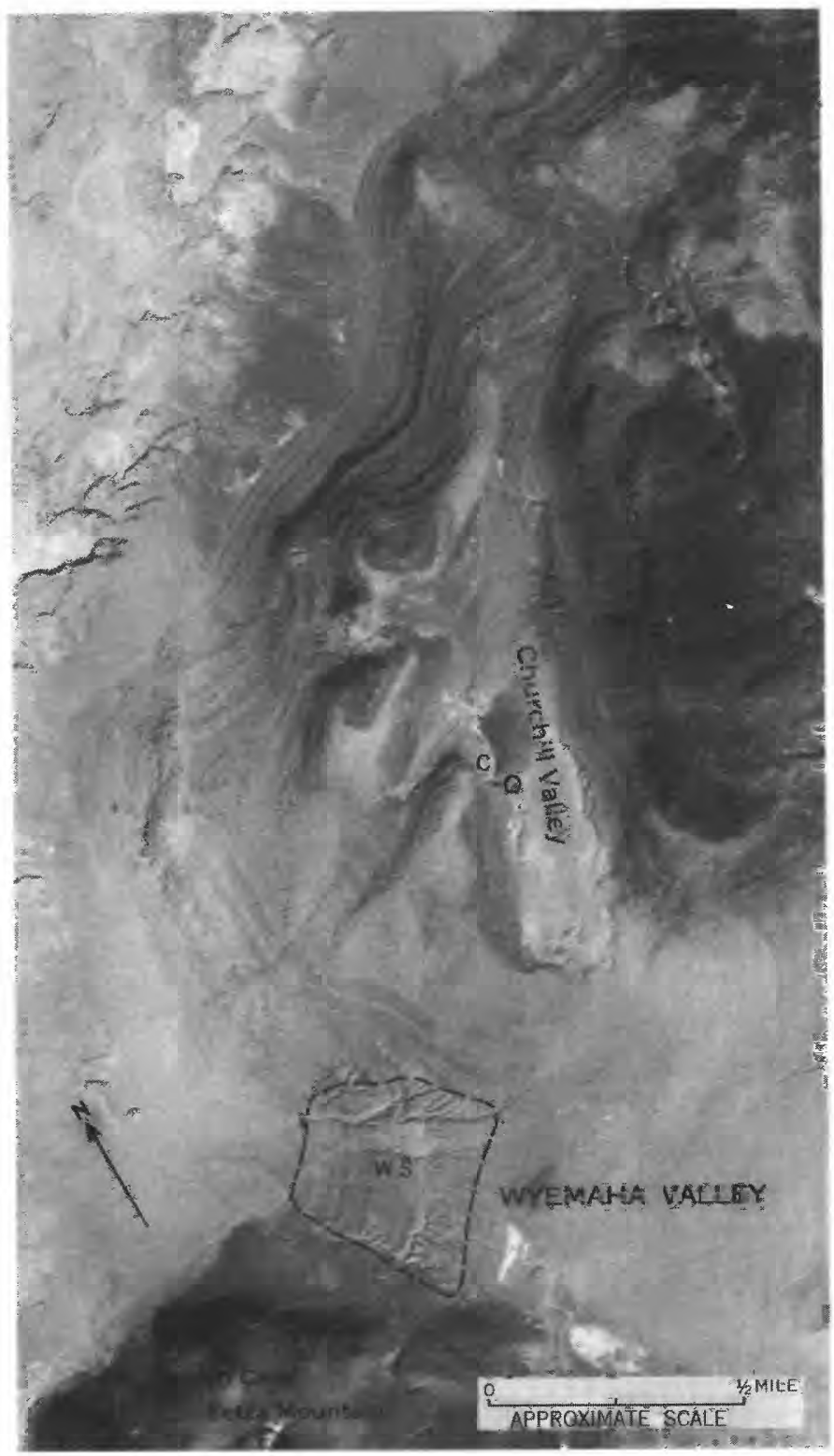

Figdre 10.-Vertical aerial photograph of part of the western Lahontan Mountains. Note contrast in minor details of topography above and below highest shoreline (Lahotan beach), of the Eetza age. The Eetza formation and coeval shorelines generally are exposed mainly on the steeper mountain shores, younger deposits and shorelines of Sehoo age elsewhere. The sharp upper altitude limit of tufa of the lower member of the Sehoo shows as the boundary between black and palegray shores, a few feet below the Lahontan beach. The following type localities are shown: Eetza formation (E) ; Wyemaha and Sehoo formations (WS); Churchill soil, lower member of the Sehoo formation and lower tongue of Indian Lakes formation (C); and middle tongue of Indian Lakes formation (Im). USGS photograph.

The 4,375- and 4,350-foot shorelines are the strongest of the higher group. Russell (1885, p. 101-103) designated the 4,350 -foot shoreline as the lithoid terrace because it lies at the upper altitude limit of his lithoid tufa; in places, however, he also applied the name lithoid terrace to the 4,375 -foot shoreline $(1885$, p. 114 and pl. 19). Where best developed, as along the north front of the Desert Mountains, both shorelines include wave-cut terraces 30 to 75 feet and locally 200 feet wide, on basalt and rhyolite; the terraces have cliff scarps commonly 20 to 75 feet and rarely 100 feet or more high. In reentrants where the Lahontan beach is lacking, the 4,375-foot shoreline is the highest discernible shoreline of Lake Lahontan, and although its strong development might suggest control of lake level by overflow, a reconnaissance of all possible places of overflow around Lake Lahontan showed no evidence of it, thus corroborating Russell's conclusion.

The 4,065-foot terrace is the best marked terrace of Lake Lahontan, being cut commonly 50 to 100 feet wide, and 300 feet wide on the most exposed shores, even on basalt and rhyolite. Terraces at altitudes of 3,980 to 4,010 feet are locally prominent at the edges of the Lahontan Mountains (especially at Grimes Point) and at the edges of the northern parts of the Bunejug and White Throne Mountains. These terraces are at about the same altitude as the thinolite terrace of Russell (1885, p. 237) in the Pyramid Lake area, but their development probably considerably antedated the deposition of thinolite tufa (p. 65, and table 5).

Eetza shorelines facing north, northwest, and west across the main basin have generally been severely eroded and in places obliterated by wave erosion in early Sehoo time, especially those between altitudes of 3,950 and 4,050 feet (fig. 11B). Elsewhere, however, particularly on shores facing south and southeast (for example, in the Lahontan Mountains), the shorelines show little or no erosion (fig. 11A). Evidently strong winds came from the south and southeast in Eetza time but not in early Sehoo time.

\section{TUFA}

The Eetza formation lacks the volume and diversity of lake tufa that characterize the Sehoo formation. It locally has small amounts of a dense stony-textured algal tufa called lithoid tufa by Russell $(1885$, p. $190-$ 192). This tufa is described in table 5. It closely resembles much of the lithoid and cellular tufas of the lower member of the Sehoo formation, and in places the two tufas cannot be differentiated. Russell did not recognize the two ages of lithoid tufa on the higher shores.

\section{INTRA-EETZA LAKE RECESSION}

Exposures of the Eetza formation generally show no intertonguing subaerial sediments, soils, or disconformities indicative of significant lake recession. The only exceptions seen are in western Wyemaha Valley and in the thick embankments of lake gravel along the 

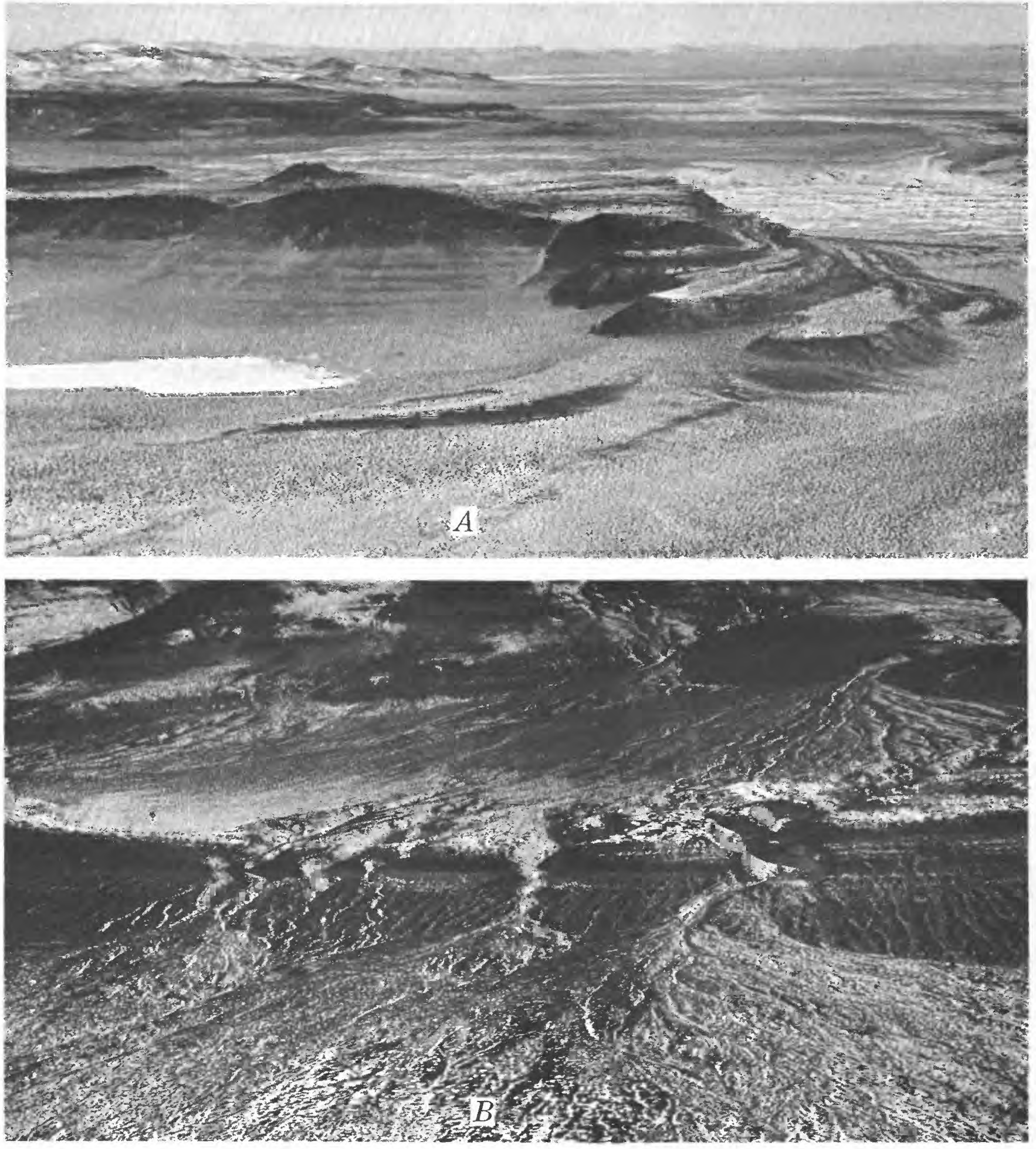

Figune 11. $-A$. Oblique aerial view of higher shorelines in southern Dead Camel Mountains at southwest edge of Carson Desert. The weak shorelines on the sheltered south-facing mountain slope at left in middle distance are of Eetza age, but the prominent spits at right are of Sehoo age. The wide bar in foreground is composite, with gravel of Sehoo formation largely burying an earlierbar of Eetza age. $B$, Oblique aerial view of compound low-level spit that extends for more than 2 miles southward from southwest edge of Bunejug Mountains (sec. 33, T. 17 N., R. 30 E.). Spit is mostly gravel of Sehoo formation, resting on a much-eroded spit of gravel of Eetza formation. The stratigraphic succession is well exposed by the wash gullies. Figure 25 shows middle part of this spit. 
north edge of the Desert Mountains. In western Wyemaha Valley a probable very weak soil was noted at the site of section $45 \mathrm{a}$ (pl. 18d and table 10) intercalated with gravel of the Eetza formation at an altitude of about 4,060 feet. In a gully at the north edge of the Desert Mountains (section 60, table 10), a disconformity and very weak soil were observed between upper and lower sand and silt zones of the Eetza at an altitude of about 4,220 feet. This evidence suggests that lake recession below 4,060 feet took place between two lake maximums in Eetza time. Recession at least as low as 4,100 feet also is indicated by a thin gravelly and sandy zone in the middle of the clay-silt lithofacies of the Eetza formation in exposures along the Truckee River below Wadsworth (Russell, 1885, pls. 24 and 25; Antevs, 1925a, p. 87-97).

In the gravel embankments along the front of the Desert Mountains, a lower gravel unit in the Eetza formation, apparently underlying the disconformity, can be traced continuously up to the Lahontan beach altitude 4,380 feet, whereas an upper gravel and sand unit of this formation that apparently overlies the disconformity can only be traced to about 4,340 feet. These relations suggest that the second lake maximum of Eetza age was about 40 feet lower than the first. The relations are best illustrated along the east side of a canyon, a quarter of a mile southwest of the site of section 60 (table 10).

\section{IAKE SAND, SIIT, AND CLAY}

Exposures of sand, silt, and clay of the Eetza formation are rare and too small to be mapped. Sand was found: on the lee side of a high-shore bar 11/4 miles northeast of Salt Wells on Salt Wells Mountain; interbedded with gravel in a spit at the Dodge gravel pit, on the east side of Turupah Flat; and, most extensively, interbedded with gravel in the thick embankments along the Desert Mountains (see table 10, section 60).

Silt and clay were noted as a few thin interbeds in the gravel embankments along the Desert Mountains, at two localities on the eastern edge of the Dead Camel Mountains, and also intertonguing with sand and gravel on lee sides of two spits of Eetza age; one on the southwestern piedmont of the Bunejug Mountains at an altitude of 4,030 feet, and one near a gravel pit on the northwest side of the White Throne Mountains at '3,990 to 4,020 feet; the two latter occurrences locally bear the Churchill soil and seem to be lagoonal deposits.

Deep offshore facies of the Eetza formation are nowhere exposed. Buried equivalents probably have been penetrated in wells but cannot be identified in the available logs.
CORRELATION WITH DEPOSITS OF LAKE LAHONTAN DESCRIBED BY RUSSELL AND ANTEVS

Excellent exposure of clay and silt of the Eetza formation in the valleys of the Humboldt, Truckee, and Walker Rivers have been described by Russell (1885, p. 124-145), who called these deposits lower lacustral clays, and by Antevs (1925a). Both geologists interpreted these clays as having been deposited during the first deep-lake period of Lake Lahontan. Russell also recognized shore terraces and gravel deposits of this age on the highland shores, although he did not designate them by a separate name.

Russell noted that the base of these clays is not exposed in the river valleys, but estimated their maximum thickness to be at least 150 feet. He described the clays as very similar to the "upper lacustral clays" (the Sehoo formation of this report), being evenly bedded, locally thinly laminated, light- to medium-dark-gray clay and silt, in places marly and saline, and commonly well jointed in exposures. The lower clays differ from the upper lacustral clays, however, in having a higher proportion of silt, in being devoid of volcanic ash layers, and almost devoid of fossil mollusks. Both Russell's and Antevs' stratigraphic sections show that the lower clays locally contain interbeds of sand and even gravel.

\section{PALEONTOLOGY}

The only fossils found in the Eetza formation in the map area are: (a) gastropod shells, locally fairly abundant in lithoid tufa associated with the lake gravel; (b) ostracod shells in sand interbedded with lake gravel at the Dodge gravel pit, on the eastern side of Turupah Flat; and (c) rare, unidentifiable fragments of mammal and bird bones in lake gravel at this same locality.

A collection of snails from lithoid tufa of this formation in a wash-bank exposure in Churchill Valley, at the type locality of the Churchill soil, was determined by Joseph P. E. Morrison, U.S. Geological Survey, as:

\footnotetext{
Parapholyx nevadensis Henderson

Physa (cf. gyrina Say?)

Stagnicola sp.
}

Each of these species and genera is still living in North America and also is found in younger deposits in the Carson Desert (table 6).

\section{ALLUVIAL GRA VEL AND COLLUVIUM OF EETza AGE}

Alluvial gravel.-Alluvial gravel considered to be of Eetza age occurs in a few places along mountain washes above the Lahontan beach. It is poorly sorted pebbleto-boulder gravel, 1 foot to rarely 5 feet thick (hence generally unmappable), and is less sandy than alluvium of the Wyemaha formation but virtually identical with 
that of the Paiute and Indian Lakes formations. It can be designated only from correlations of $\mathrm{C}_{\mathrm{ca}}$ horizons which are inferred to represent the Cocoon and Churchill soils (B horizons generally are eroded), as follows: Where the alluvium of a wash bears two $\mathrm{C}_{\mathrm{ca}}$. horizons, the lower one very strongly, the upper only strongly developed, the lower one is inferred to be the Cocoon soil and the alluvium bearing it, Paiute formation; the alluvium overlying it and bearing the strong Cca horizon is inferred to be of Eetza age if it is low in sand and of Wyemaha age if sandy. Where the $\mathrm{C}_{\mathrm{ca}}$ horizons are lacking no designation can be made with confidence. In a few places along the north front of the Desert Mountains, alluvial gravel of Eetza age intertongues with lake gravel of the Eetza formation.

Colluvium.-Colluvium of Eetza age is widespread in the highlands above the Lahontan beach and has not been recognized below this shoreline, but it is invariably too thin and discontinuous to be shown on the geologic map. It consists of solifluction and creep mantle and overlies similar colluvium of the Paiute formation. The contact is commonly diconformable and lies at the top of the $\mathrm{C}_{\mathrm{ca}}$ horizon of the Cocoon soil: The younger colluvium formed mainly as a result of solifluction and creep of the earlier colluvium in the uncemented B horizon of this soil, and the B horizon colors it pale reddish brown. Some white caliche from the underlying $\mathrm{C}_{\mathrm{c}}$ horizon of this soil is commonly incorporated. On slopes of less than $5^{\circ}$ the colluvium is absent or is only several inches thick. The thickest deposits, locally several feet thick, are on the lower parts of slopes steeper than $15^{\circ}$. The colluvium thickens with altitude, but this tendency is more evident in the higher ranges, such as the Stillwater Range, than in the low mountains of the map area.

\section{WTEMAHA FORMATTON GENERAL FEATURES}

The formation was named (Morrison, 1961a) for Wyemaha Valley, and its type locality is in the saddle between Sehoo and Eetza Mountains at the western end of the valley (El/2 sec. 21, T. 18 N., R. 30 E.). Along the washes at the north and south edges of this saddle eolian sand of this formation is exposed extensively. The sand bears the Churchill soil (which commonly is partly eroded), overlies the Eetza formation and underlies the Sehoo formation (pls. 7, 8; table 10, sections 42-45).

The Wyemaha formation consists of eolian sand, alluvial gravel and sand, and shallow-lake sand, silt, and clay. Most of the formation lies conformably or with only slight disconformity between the Eetza and Sehoo formations, but the eolian sand extends in the high- lands to altitudes much above those reached by the lakes and here. lies on older units. The subariel sediments extend to the lowest parts of the former basin floor, where they are intercalated with the shallow-lake sediments. Obviously this formation records a time when Lake Lahontan was intermittently dry and at very low levels. It bears the Churchill soil (p. 38), which occurs on beds as high stratigraphically as the youngest beds of this formation but not on younger deposits.

The formation is widely exposed in the map area. In contrast to the Paiute and Eetza formations, it crops out extensively in the lowlands as well as in the highlands, although in the lowlands only the uppermost part is exposed. Above an altitude of 3,990 feet it consists of eolian sand and small amounts of alluvial gravel and sand. Below 3,960 feet it is mainly shallow-lake sand, silt, clay, and muck (lithologically distinctive from the overlying Sehoo sediments), and minor amounts of eolian sand and alluvium. Between altitudes of 3,990 and 3,960 feet it is intertonguing subaerial and shallowlake sand.

\section{CORRELATION WITH DEPOSITS OF LAKE LAHONTAN DESCRIBED BY RUSSELL AND ANTEVS}

The Wyemaha formation correlates with Russell's (1885, p. 125-143) "medial gravel," which is exposed in the inner valleys of the Truckee, Walker, and Humboldt Rivers, interbedded between the "upper lacustral clay" (Sehoo formation of this report) and the "lower lacustral clay" (Eetza formation of this report). The medial gravel consists mostly of river and deltaic gravel and sand, and local wash gravel, ranging from several feet to 100 feet in thickness. Exposures along the Truckee River below Wadsworth are at altitudes as low as about 3,950 feet. Antevs (1925a) compiled several stratigraphic sections in the valleys of the Humboldt and Truckee Rivers that show this unit. Evidence contrary to his interpretation that the main deposition of thinolite tufa dates from this major middle Lake Lahontan recession is presented on pages $51,59,65,108$ and table 5 .

\section{EOLIAN SAND}

Eolian sand of the Wyemaha formation is widely but unevenly distributed through the highlands, varying with the relation of source areas and mountains to prevailing-wind directions and land masses in the paths of migration of the sand (p. 99,100). Principal sand drift was through the basins and lower passes; thus the chief deposits are in Wyemaha Valley, the pass area between the Stillwater and Rainbow Mountains, Simpson Pass and the northern foothills of the Cocoon Mountains, the southern Dead Camel Mountains, and the Carson Desert. The higher mountains are free from the sand, 

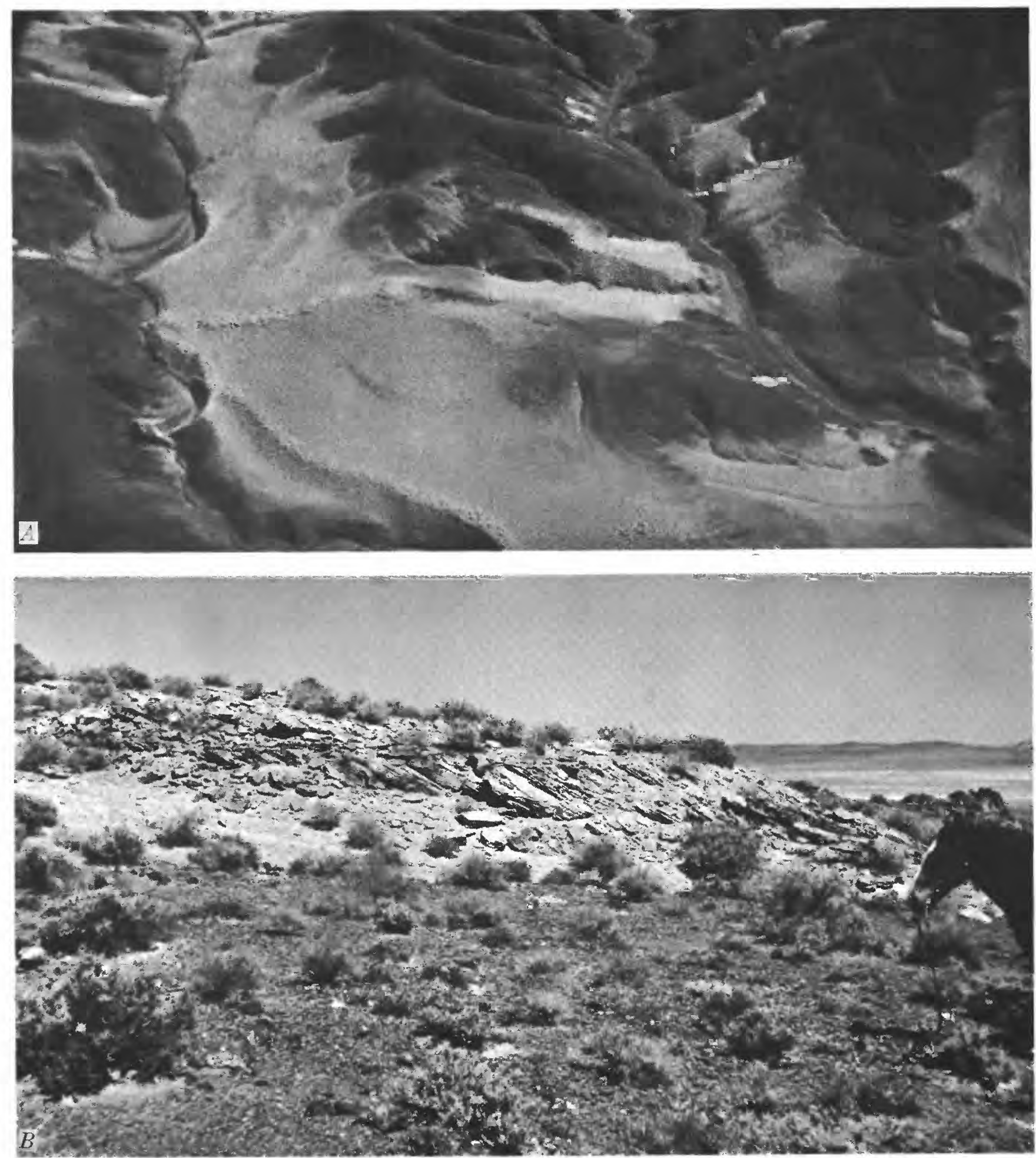

FIGURE 12.-A, Oblique aerial view of valley "drowned" by eolian sand of Wyemaha formation in the southern Stillwater Range. The light-colored areas are mostly this sand, locally with a thin veneer of eolian sand of Fallon formation derived by wind reworking of the older sand. $B$, Crossbedded eolian sand of Wyemaha formation overlying a pavement of gravel of Eetza formation. The sand is cemented by siliceous sinter deposited by an extinct hot spring, which accounts for its unusual resistance to erosion. Southeast edge of the Bunejug Mountains, sec. 26 (unsurveyed), T, 17 N., R. $30 \mathrm{E}$. 
except for local deposits lodged in canyons or sheltered slopes (fig. 12A). The sand now in the highlands, however, seems to be only a small fraction of that deposited; that it has been largely stripped from large areas is shown by remnants of the sand and by the sandy character of the local alluvium. Severe erosion has largely destroyed the former dune morphology. This sand ranges widely in thickness, and probably exceeds 100 feet in places. The base of the thicker deposits commonly is not exposed.

Good exposures showing stratigraphic relations can be seen at: (a) the type locality of the Wyemaha formation; (b) the main gulch in the central part of Eetza Mountain (section 40, table 10); (c) Churchill Valley, especially the type locality of the Churchill soil (p. 38-39); and the small gulch on the eastern side of this valley where the overlap of the sand upon gravel of the Eetza formation is especially well exposed; (d) the northeastern Cocoon Mountains (fig. 5 and table 10, section 55); (e) washes at the west edge of the Stillwater Range within the map area; and (f) the northeast edge of the Dead Camel Mountains.

The sand is practically constant in lithology, except for changes in color and induration and local lenses of alluvial and colluvial sand and gravel. The sand grains are typically eolian - fine to medium sized and frosted. Quartz greatly predominates, and some feldspar and a small percentage of mafic minerals-hornblende, pyroxene, bronzy biotite, and others-generally are present. Eolian crossbedding, caused by migrating dunes, is common in exposed sites (fig. 12B), but only parallel, generally inclined, and indistinct bedding is present in canyons or other sheltered sites.

Pale-yellowish color and moderate induration-both probably the result of development of the Churchill soil-are distinctive of the upper 10 to 20 feet of the sand where it is not eroded. The yellowish color is most pronounced in the uppermost part of the sand-commonly very pale brown, yellow, light yellowish brown, or brownish yellow ( $10 Y R 7 / 4$ to $6 / 6$ ) ; this color decreases in intensity downward, but commonly even exposures well below the soil profile are pale yellow (about $5 Y 8 / 4$ ). The induration is caused by calcium carbonate cementation, and is most pronounced in the calcareous horizon of the Churchill soil. Slight to moderate induration commonly extends 10 to 15 feet below the soil profile, but normally the sand at greater depth is not indurated. The indurated part commonly shows crude very coarse prismatic.jointing, as well as local white calcium carbonate concentrations along bedding and joint planes and cylindrical calcium carbonate root casts. In eastern Wyemaha Valley and on the piedmonts east of the Bunejug Mountains, northeast of the Cocoon Mountains, and south of Salt Wells Mountain, the sand is locally cemented by siliceous sinter from extinct springs and seeps (fig. 12B).

\section{ALLUVIAL AND COLLUVIAL GRAVEL AND SAND}

Alluvium of the Wyemaha formation is exposed locally in the mountain valleys and along drainage lines on the piedmonts, but few bodies are mappable. Some alluvium is interbedded with eolian sand as lenses, 1 foot to rarely 15 feet thick, of sand, pebbly sand, and very sandy gravel, but most alluvium overlies eolian sand or occurs without eolian sand, and is sandy gravel (sandier than the other alluvial gravels in the highlands) 2 to 10 feet thick. Most of this alluvium is evidently younger than the eolian sand. It generally was completely eroded where exposed to strong wave action by the early Sehoo lake.

Colluvium is relatively insignificant. It consists mostly of local thin beds, too small to map, of poorly sorted gravelly to sandy slope wash intertonguing with the eolian sand, which abuts against steep slopes.

\section{INTERBEDDED SHALLOW-LAKE AND SUBAERIAL SEDIMENTS}

The extensive exposures of Wyemaha formation in the interior lowlands, below altitudes of 3,990 feet, are mainly shallow-lake sand and a little lake silt and clay interbedded locally with eolian sand, alluvium, and (only near Upsal Hogback) basaltic tuffaceous sand and silt. These sediments are exposed in deflation basins and plains that were eroded through the Sehoo formation, mostly in the western part of the map area. The exposures rarely extend more than a few feet below the contact between the Wyemaha and the Sehoo, but the deepest ones, in the deflation basins bordering Upsal Hogback, extend 30 to 40 feet below it. The subaerial beds are too small in outcrop to map separately; they are most common in the western half of the area. The Wyemaha formation generally underlies clay of the Sehoo formation with a sharp conformable contact that is readily mappable wherever it is exposed over a vertical range from about 3,870 to 3,990 feet. The Wyemaha is yellowish or brownish well-sorted sand and the Sehoo is light-gray clay. The sand of the Wyemaha is an aquifer, and where it is exposed the water table generally is within a few feet of the surface, which is generally coated with white efflorescent salt, and is either devoid of vegetation or has only saltgrass, or rarely, pickleweed.

The shallow-lake sediments, everywhere dominant, are largely sand and only local beds or partings of silt and clay. The beds are various light shades of yellowish-brown and gray medium- to fine-grained sand, generally unconsolidated, and well sorted. They 
range from a few inches to several feet in thickness, and from well bedded to indistinctly bedded. Stratification generally is parallel, though locally it is inclined. Intertonguing relations and similar mineralogy of the lake and eolian sands show that the lake sand was derived mainly by wave reworking of eolian sand. The uppermost foot or several feet of lake sand beneath the clay of the Sehoo formation is nearly everywhere yellower and deeper hued than the underlying beds-yellow, brownish yellow, and light yellowish brown $(2.5 Y 7 / 6$ to $10 Y R 6 / 5$ and $6 / 4$ ) and light brownish gray to grayish brown $(2.5 Y 6 / 2$ and $5 / 2)$.

Eolian sand is locally interbedded with the lake sand in beds 1 foot to several feet thick. The best exposures are at the scarps of deflation basins east and south of Upsal Hogback, where the eolian sand extends as low as 3,920 feet. Other localities are the lowlands of the western half of the Fallon quadrangle; the west bank of the Carson River 3 miles north of Fallon at an altitude of 3,930 to 3,935 feet (section 13, table 10); and the northeast and southwest edges of Eightmile Flat, at an altitude of 3,915 to 3,940 feet.

Alluvium of this unit was not seen in outcrop. Several boreholes in the western part of the area penetrated beds of pebbly coarse sand and sandy gravel in the formation ( $\log 20$, table 12 ) within a few feet of the surface; some of these beds probably are alluvium and are possibly former channels of the Carson River.

In the deflation basins bordering Upsal Hogback, the deeper exposed strata are tuffaceous, whereas the upper 8 to 20 feet of the formation are virtually nontuffaceous (section 6, table 10). The tuffaceous beds are dark gray to black basaltic sand and silt; they intertongue with nontuffaceous lighter colored sand, silt, and clay. The tuffaceous beds are generally well sorted, evenly bedded, and moderately to well indurated; they appear water laid and are probably lacustrine. They thicken toward Upsal Hogback and probably intertongue with the subaerial tuff and tuff breccia of the hogback (p. 38), but the zone of gradation is poorly exposed. These relations suggest that the tuffaceous beds were derived from eruptions of Wyemaha age at Upsal Hogback. In mapping this tuffaceous facies the outer indefinite boundary was placed where at least half of the beds contain at least 5 percent basaltic grains. The tuffaceous facies generally extends no more than $1 \frac{1}{2}$ miles from the hogback, but along the partly buried horst that protrudes southward from the hogback it crops out intermittently in deflation basins for 4 miles. Partings of basaltic sand have been found locally in exposures and boreholes several miles from the hogback (section 2, table 10).

Blocks of black vesicular olivine basalt, commonly 1 foot and rarely 4 to 6 feet across, occur in many places in the western half of the Stillwater quadrangle in lake sand of the Wyemaha near the contact between the Wyemaha and the Sehoo. They are fairly numerous west of the Carson River and south of Carson Sink, and a few large ones have been seen as much as $11 / 2$ miles east and northeast of Rattlesnake Hill. Their derivation is uncertain; perhaps they were ice rafted across the lake.

\section{SUBSURFACE BASIN SEDIMENTS}

A few dozen logs of auger borings, made partly in the present investigation and partly in early groundwater studies (Herman Stabler, written communication, $1904)$; C. H. Lee and W. O. Clark, written communication, 1916), and driller's logs of water and oiltest wells give reliable information on the upper part of the Wyemaha formation in the subsurface of the basin interior. The uppermost 5 to 30 feet of the formation is mainly lake sand like that just described except that the uppermost bed commonly lacks the brightyellowish or yellow-brown color typical of exposures. This sand is thickest in the western part of the map area, where it is an important aquifer. It thins toward the lower parts of the present basin floor, and locally pinches out or grades into fine sand, silt, and silty clay: The contact between the Wyemaha and the Sehoo generally is sharp (within 1 or 2 feet) however, for the finer facies of the Wyemaha characteristically are more organic and darker than the clay of the Sehoo.

Beneath the upper sandy zone is a thick section of alternating thin sandy and clayey units whose base is not clearly defined by data from the available well logs. Sand predominates in the Carson River delta area west of Fallon, and interbeds of gravel and sand, which may be fluvial or deltric deposits of the river, occur locally (see logs $15 \mathrm{~L}$ and $21 \mathrm{~L}$, table 12 ) ; beds containing appreciable organic material are lacking or few. The proportions of silt, clay, and highly organic beds increase toward Carson Lake, Stillwater Slough, Stillwater Lakes, Carson Sink, and Eightmile Flat; locally beneath these low-lying areas the upper part of the Wyemaha is organic muck and clay (the transitional facies is illustrated by $\operatorname{logs} 14 \mathrm{~L}, 19 \mathrm{~L}$, and $27 \mathrm{~L}$, and the low-lying facies by logs 38 and 52, table 12). The more highly organic sediments are dark gray to black and have a strong peaty, and in places, hydrogen sulfide odor. Well drillers call these sediments black gumbo, black tule clay, black tule sand, black clay, black sand, and the like. In the Carson Lake and Stillwater Lakes areas, where they are especially prominent, they yield small amounts of natural gas (p. 114, 115), but several tests for petroleum by carbon tetrachloride extraction were negative. 
Where the upper sandy zone is absent beneath the low-lying areas, clay of the Sehoo formation commonly rests directly on highly organic black silt and silty clay (true muck), as at Eightmile Flat and in places in the southeastern part of Carson Sink and in the Carson Lake-Stillwater Lakes area. The top of the muck beds is at an altitude of about 3,880 feet along Stillwater Slough and about 3,900 feet at Eightmile Flat. At Eightmile Flat the muck is highly saline, probably because of salts from the numerous highly mineralized springs and seeps at the edges of this flat; elsewhere it generally is not saline.

In several wells sediments, which are tentatively correlated with the Wyemaha formation because of their high proportions of sandy or organic beds and their absence of thick clay units, extend at least 100 to 150 feet below the contact between the Sehoo and the Wyemaha $(\operatorname{logs} 19 \mathrm{~L}, 27 \mathrm{~L}, 38 \mathrm{~L}$, and $52 \mathrm{~L}$, table 12$)$, but the base of the formation cannot be identified in any of the wells; thus the maximum thickness of the Wyemaha in the subsurface of the basin interior may be considerably greater.

\section{PALEONTOLOGY}

Three collections of fish bones from the uppermost beds of lake sand were examined by D. H. Dunkle of the U.S. Geological Survey. One collection, from a deflation-scarp exposure 1.4 miles east of the Upsal Hogback saddle, is possibly either Rhabdofario or Salmo. The other two collections, one from the east bank of the Carson River in sec. 19, T. 21 N., R. 30 E., and the other from beside the Fallon-Lovelock cutoff in sec 6, T. 21 N., R. 29 E., he identified as mixtures of perhaps two suckers (family Catostomidae), carp (family Cyprinidae), and possibly also a bullhead (family Cottidae). None of the collections are diagnostic of age because these genera and families range from late Tertiary to Recent.

\section{BASALTIC TUFF OF UPSAL HOGBACK}

Upsal Hogback, 10 miles north of Fallon, is a series of overlapping cones of basaltic tuff that are partly or entirely of Wyemaha age. Interference by younger cones and widespread covering by eolian sand has obscured the age relations of the older cones, but at least 4 and possibly 7 vents are evident. The two oldest are at the northwest and southwest edges of the series; they are most eroded, very poorly exposed, and may be older than the Wyemaha formation. Probably the youngest is at the north end; its crater is roughly circular and about half a mile in diameter.

The cones are composed of well-indurated basalt cinder tuff, highly olivine-rich (picritic), in places containing as much as 30 percent olivine. The tuff is mostly sand, grit, and small-pebble-sized angular fragments and is poorly sorted and indistinctly to well bedded; it apparently was deposited subaerially. Within a few hundred feet of the edges of the craters it contains a few blocks one-half to 1 foot across, and rarely 2 to 4 feet across, but a quarter of a mile or more from the craters the larger fragments are cobble sized and rare. The blocks are basaltic to intermediate lava, unlike the enclosing tuff; probably they came from underlying Tertiary lavas. The tuff beds generally $\operatorname{dip} 2^{\circ}$ to $15^{\circ}$ radially outward, flattening away from the craters, but close to the craters they locally have steeper dips as well as abrupt changes in dip because of faulting and local unconformity. This tuff seems to interfinger with and grade into the basaltic tuffaceous facies of the Wyemaha formation (p. 37), but the zone of gradation is poorly exposed. The tuff is overlain by gravel, sand, and tufa of the lower and dendritic members of the Sehoo formation. The lake gravel commonly closely resembles the tuff in the outer parts of the cones because it was derived solely from the tuff, but generally it is less indurated, better sorted, more regularly bedded, and in places contains lithoid or coralline tufa of the lower member of the Sehoo.

Large eruptions at Upsal Hogback in Wyemaha time are suggested by the apparent gradation and intertonguing of the subaerial tuff with the Wyemaha formation, and by the abundance of basaltic material in the tuffaceous facies of the Wyemaha near the hogback and a decrease in this material away from it. The earlier cones may be older than the Wyemaha-their age relations to basin sediments are not exposed-but there is no evidence of the Eetza formation or earlier units on them. The main eruptions ended before late Wyemaha time, for the upper part of the Wyemaha near the hogback is largely devoid of basaltic material. The two thin beds of basaltic sand in the lower part of the Sehoo in the northern part of the Stillwater quadrangle (p. 59) are tentatively correlated with eruptions at Soda Lake because of their large content of nonbasaltic grains, although they might record minor outbursts of the dying phase of activity at the hogback.

\section{CHURCHILL SOIL}

GENERAL RELATIONS AND DISTRIBUTION

No soils are intercalated with the Wyemaha formation. A strongly developed soil stratigraphically overlies the youngest subaerial beds of this formation, however, and is older than the Sehoo and Indian Lakes formations. This soil is called the Churchill soil after its type locality, Churchill Valley. The Churchill soil was previously referred to (Morrison, 1961a, p. D112) as the middle Lake Lahontan soil. It is much more 


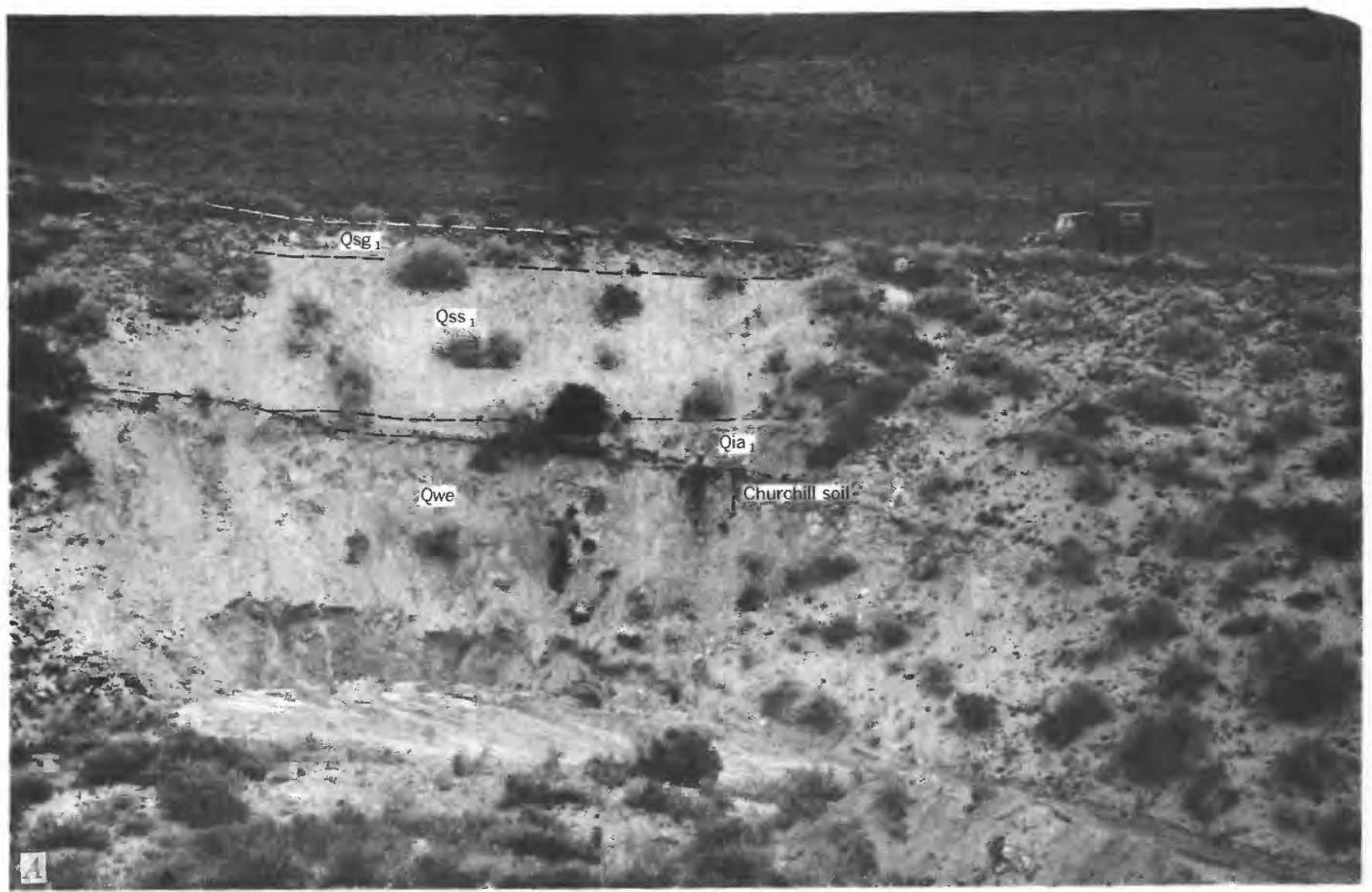

FIgure 13. $-A$, Composite type locality for Churchill soil, lower member of Sehoo formation, and lower Tongue of Indian Lakes formation (section 34, table 10). The somewhat resistant layer in the middle of the light-colored area is the Churchill soll. It developed on eolian sand of Wyemaha formation (Qwe) and is overlain successively by alluvial sand of lower tongue of Indian Lakes formation $\left(Q_{i a}\right.$ ) and sand and gravel of lower member of Sehoo formation (Qss and $\mathrm{Qsg}_{1}$, respectively). Middle part of wash on west side of Churchill Valley, S1/2 sec. 15, T. 18 N., R. 30 F. B, Churchill soil at above locality. $B=$ oxide horizon light brown; partly concealed by slumping of the loose overlying sand); Cca=calcareous horizon (about $3 \mathrm{ft}$ thick). See soil profile $34 \mathrm{~S}$.

strongly developed than any younger soil, though considerably less so than the Cocoon soil. It cannot be recognized where it is superposed on relict occurrences of the Cocoon soil because it is masked by the latter's stronger development.

The Churchill soil has been observed at altitudes ranging from 3,920 to 5,000 feet in the map area. It has not been found below 3,920 feet, although it probably once extended lower and was eroded by the transgression of the early Sehoo Lake. Below altitudes of 3,870 to 3,850 feet in the subsurface of the basin interior, its stratigraphic position, as determined by direct tracing by boreholes, seems to be represented by the more or less highly organic silt, clay, and sand in the uppermost part of the Wyehama formation, laid down

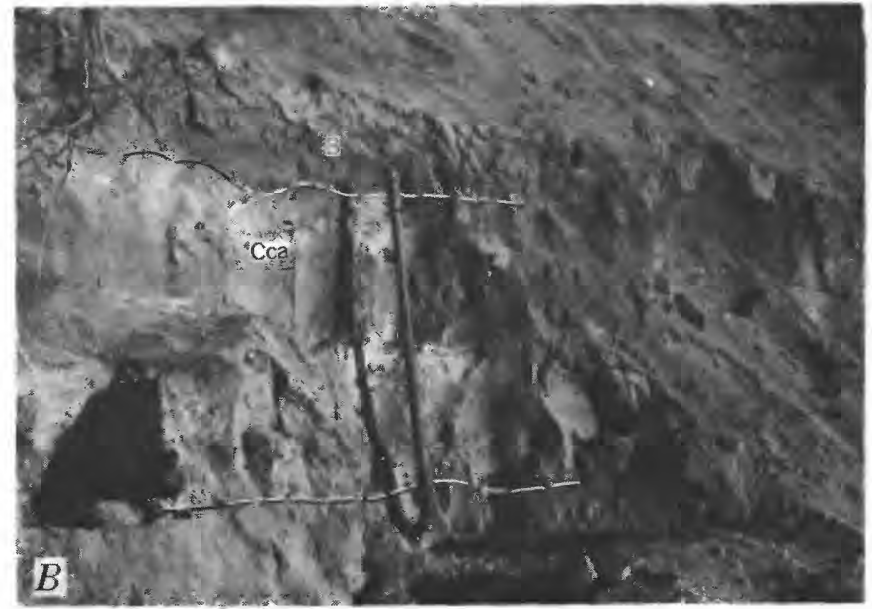

in a shallow lake that existed while the soil was forming on land.

Type locality.-The type locality for this soil is Churchill Valley, in the SE1/4SW1/4 sec. 15, T. 18 N., R. 30 E. (section 34 , table 10 ; profile $34 \mathrm{~S}$, table 11 ; and fig. $13 A, R)$, where the soil is developed on eolian sand of the Wyemaha formation and is overlain conformably by alluvial sand of the Indian Lakes formation and gravel and sand of the Sehoo formation. It 
is preserved with almost no subsequent subaerial and lake erosion because of prompt burial and a location exceptionally sheltered from waves.

\section{PROFILE CHARACTERISTICS}

The Churchill soil is a Calcic Brown soil throughout the relatively narrow altitude range in which it occurs in the map area. Relict and buried occurrences show no appreciable differences in profile characteristics. The full profile is rarely seen, for it generally has been more or less eroded. It is well preserved only in the most protected mountain reentrants and valleys below the highest shoreline of the early Sehoo lake, on gravel of the Eetza formation in the narrow zone between the early Sehoo high shore shoreline and the Lahontan beach, and locally on colluvium and alluvium of Eetza age and on the Wyemaha formation in the highlands above the Lahontan beach.

A vesicular horizon has not been positively identified in any buried occurrences of this soil. Such a horizon is locally present on relict occurrences, but it is probably younger than Churchill soil because it locally crosscuts the top of the oxide horizon and closely resembles the vesicular horizon of the Toyeh soil. On relict occurrences a layer of lag gravel commonly overlies the vesicular horizon. Generally the gravel layer is only 1 pebble thick and similar to that on relict occurrences of the Cocoon and Toyeh soils; it also is presumed to be younger than the Churchill soil. The upper surfaces of the pebbles typically are coated with desert varnish, which is somewhat better developed than that on lag gravel on the Toyeh soil.

The oxide (B) horizon is about 12 to 18 inches in full thickness in the few places where the soil is preserved with little apparent erosion. Where developed on eolian sand and sandy colluvium, this horizon is light brown (7.5YR 6/3), pale brown (10YR 6/3), light yellowish brown $(10 Y R 6 / 4)$, and locally light brownish gray $(10 Y R 6 / 2)$; consistence is slightly hard to hard, and structure is weak to moderate grades of coarse prismatic, coarse columnar, or coarse to very coarse subangular or angular blocky. On gravel containing mafic volcanic rocks or on gravelly colluvium of Eetza age that has been reworked from the $\mathrm{B}$ horizon of the $\mathrm{Co}$ coon soil it commonly is brown (about $7.5 Y R 5 / 3$ to $10 Y R 5 / 3)$ to locally reddish brown $(5 Y R 5 / 3)$, reddish gray $(5 Y R 5 / 2)$, and dark reddish gray $(5 Y R$ $4 / 2$ ); consistence is slightly hard and structure is single grain to a weak grade or coarse granular or coarse subangular blocky.

The upper half or two-thirds of the horizon (the $\mathrm{B}_{2}$ subhorizon), compared with the lower part, is somewhat darker and harder, has somewhat stronger structure, is free of calcium carbonate, and has a $\mathrm{pH}$, determined by colorimetric field tests, generally between 6.5 (slightly acidic) and 7.5 (mildly alkaline). Determinations of $\mathrm{pH}$ by glass electrode, however, range from 8.3 to 9.0. A slight concentration of silt and clay commonly is evident in this part of the horizon: Mechanical analyses of samples (freed of organic matter) from several localities showed 7 to 16 percent of particles less than $0.02 \mathrm{~mm}$ in diameter. The sand grains show little evidence of corrosion.

In the lower third or half of the horizon (the $\mathrm{B}_{3}$ or $\mathrm{B}_{\mathrm{ca}}$ subhorizon, transitional into the $\mathrm{C}_{\mathrm{ca}}$ horizon), the color gradually lightens downward, structure becomes somewhat weaker, and calcium carbonate concentration gradually increases.

The calcareous $\left(\mathrm{C}_{\mathrm{ca}}\right)$ horizon normally ranges from 2 to 4 feet in thickness. Its upper boundary is $21 / 2$ to 6 inches wide, that is, gradual to diffuse, and its lower boundary generally is diffuse and irregular. Concentration of calcium carbonate characterizes this horizon-strong in the upper part and decreasing downward. The concentration generally is irregular: most of the calcium carbonate is concentrated in whitish streaks and irregular or mottled disseminations, interspersed with more weakly cemented material, which generally is light gray $(10 Y R 7 / 2)$, very pale brown $(10 Y R 7 / 3)$, and pale brown $(10 Y R 6 / 3)$. Consistence is slightly hard to hard and structure is massive. Because of the calcium carbonate cementation this horizon is somewhat resistant to erosion. Both colorimetric field tests and glass electrode $\mathrm{pH}$ determinations range from about 8.0 to 9.4 (moderately to very alkaline). Downward, as the calcium carbonate concentration decreases, the consistence changes to soft, and structure to single grain.

In eolian sand, this horizon is thicker and the carbonate more irregularly dispersed than in other materials; moreover, the sand generally is weakly indurated by slight calcium carbonate cementation for about 10 feet below the true calcareous horizon (fig. 13B). Cylindrical calcium carbonate concentrations, which were apparently precipitated about former roots, are common; they range from one-fourth to three-fourths of an inch in diameter and have tiny hollow centers. In gravel of calcic rocks (for example, basalt and andesite), this horizon generally is about 3 feet thick and has more calcium carbonate than in eolian sand (fig. 14). In lake clay it is only $11 / 2$ to 2 feet thick, and the carbonate concentration is unusually strong in the upper half owing to the low permeability of the clay.

Compared with the Cocoon soil, the Churchill soil has an oxide (B) horizon that is less clayey, softer, weaker structured, lighter colored, and yellower; it has 


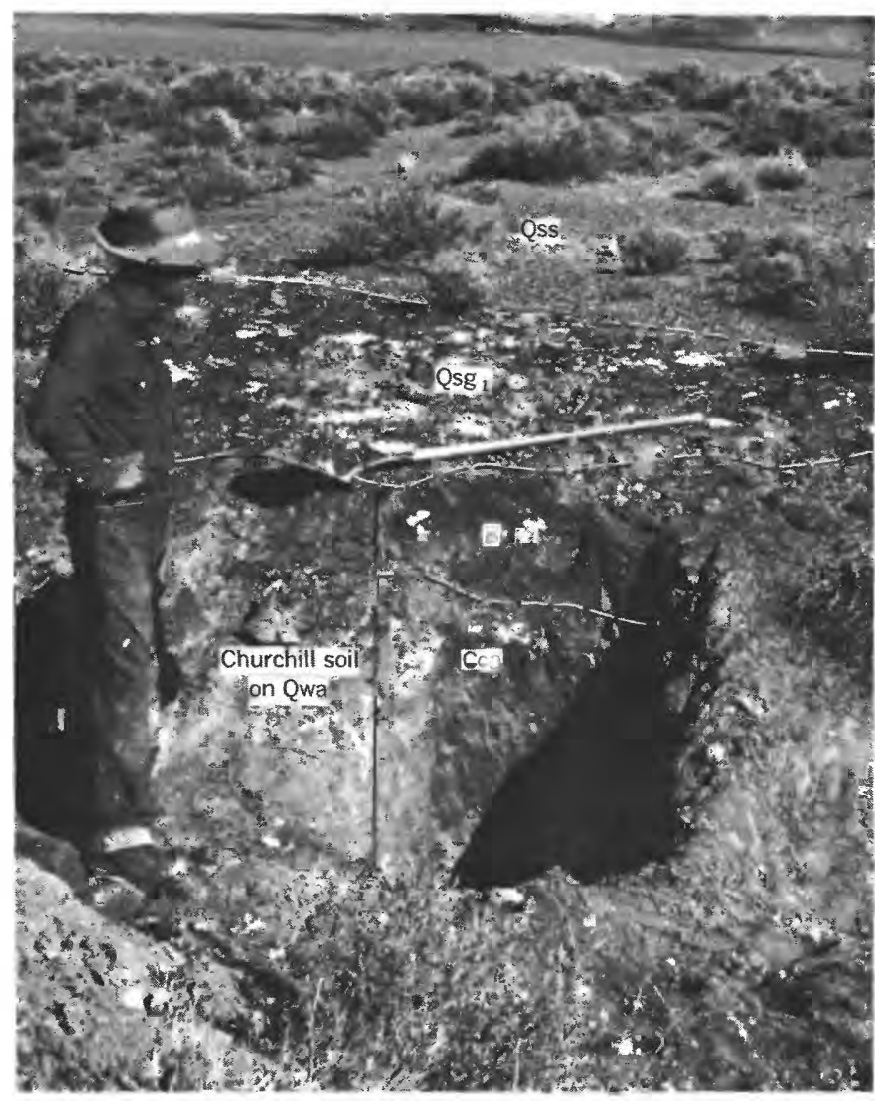

Figure 14.-Churchill soil, developed on alluvial gravel of Wyemaha formation (Qwa), and buried by gravel of lower member of Sehoo formation $\left(\mathrm{Qsg}_{1}\right)$ and sand of lower and dendritic members of Sehoo (Qss). The gravel of lower member of the Sehoo is unusually thin because this locality was sheltered from strong waves. B, oxide horizon (somewhat eroded by the early Sehoo lake); Cca, calcareous horizon. Beside road along east side of Rainbow Mountain, nea 4,160-foot bench mark, in sec. 16 (unsurveyed), T. 18 N., R. 31 E.

a calcareous $\left(\mathrm{C}_{\mathrm{ca}}\right)$ horizon that is considerably thinner, less strongly impregnated with calcium carbonate, softer and less resistant, and somewhat darker.

\section{SEHOO FORMATION}

GENERAL FEATURES

Two major coeval units in the Lahontan Valley group overlie the Churchill soil and Wyemaha formation (and older units, locally, where these are missing), and are discontinuously overlain by the Turupah formation, Toyeh soil, and Fallon formation. One of these units, which has been named (Morrison, 1961a) the Sehoo formation after the Sehoo Mountains, consists entirely of lake sediments. The other unit, which has been named (Morrison, 1961a) the Indian Lakes formation after the Indian Lakes northeast of Fallon, is predominantly subaerial sediments that locally intertongue with the Sehoo formation.

The Sehoo formation records the late deep-lake period of Lake Lahontan. Unlike the older Quaternary units, this formation is fully exposed in many places in both highlands and lowlands; it is the most widely exposed of the Pleistocene formations. In the highlands it consists of lacustrine gravel, sand, and local lake silt, clay, and tufa; the maximum shoreline is at an altitude of about 4,370 feet. Along the base of the highland shores, between 4,000 and 3,940 feet, the formation changes facies, through a narrow silty zone, to clay that underlies all the lowlands.

The type locality is the saddle between Sehoo Mountain and Eetza Mountain, at the west end of Wyemaha Valley in the E1/2 sec. 21, T. 18 N., R. 30 E. Here, typical lithologies of highland shore occurrences of all members of the Sehoo are represented, overlying both eolian sand of the Wyemaha formation and gravel of the Eetza formation (pls. 7, 8; sections 41-45, table 10). The following further illustrate the stratigraphic relations and lithology of highland occurrences of this formation: figures $5,13 A, 15 A-C$, and 25 ; and sections $32,34,40,50$, and 55 (table 10). The following illustrate lowland occurrences: figures $9,12,16$, and $30 \mathrm{~A}$; and sections $3,7,18$, and 29 (table 10 ).

The Sehoo-Wyemaha boundary is generally clearly marked and conformable or only slightly disconformable: on the highland shores it is the base lake gravel and sand (Sehoo) resting on eolian sand or alluvial gravel (Wyemaha) ; in the lowlands it is the sharp conformable contact between clay and sand (or between nonorganic clay and organic sand, silt, and clay) described on pages 36-37. The Churchill soil is a conspicuous marker where present, but it is absent (apparently eroded) in the lowlands. At the base of the highland shores and on the Carson River delta the boundary is locally gradational and indistinct, as the clay at the base of the Sehoo formation changes facies upslope to sand and the shallow-lake sand of the Wyemaha changes to eolian sand and alluvium. Even in such places, however, the contact generally can be drawn within the accuracy tolerances of the maps.

The Sehoo formation corresponds to the "upper lacustral clay" of Russell (1885), and correlative shore gravel and sand of his "second rise of Lake Lahontan." (See p. 106 and fig. 38.) It also corresponds to the deposits of the "Dendritic Lake" of Antevs (1925a, 1945, 1952).

Gravel and tufa of the Sehoo formation vary considerably among the four members of the formation in details of lithology and distribution, as outlined in the following sections and in tables 4 and 5. Sand is less variable in lithology but differs considerably among the members in distribution. The clay unit, which includes silt, is the least variable in both respects; its general characteristics are summarized below. 

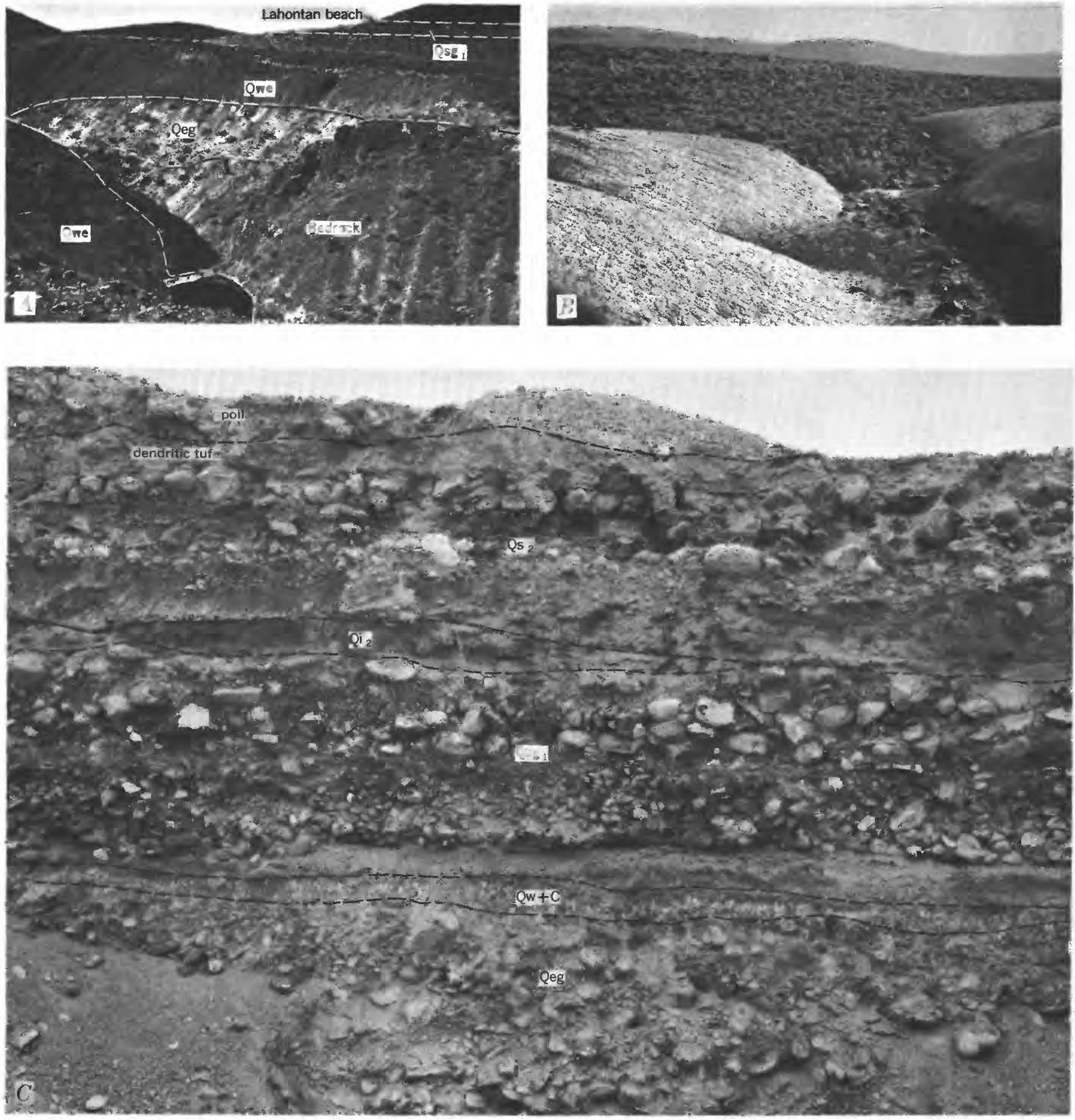

Figure 15. - A, Gravel of lower member of Sehoo formation $\left(Q_{\mathrm{sg}_{1}}\right)$ overlying eolian sand of Wyemaha formation (Qwe) and gravel of Eetza formation (Qeg) - relations typical of many sheltered mountain valleys below the Lahontan beach. Southeast edge of Bunejug Mountains, NW $1 / 4$ sec. 35 (unsurveyed), T. 17 N., R. 30 E. B, Overlap of clay of Sehoo formation upon gravel of Eetza formation. North edge of White Throne Mountains, E1/2 sec. 4, T, 16 N., R. 29 E., altitude about 3,970 feet. $C$, Stratigraphic detail typically seen in good exposures. At base, gravel of Eetza formation (Qeg), which is successively overlain by: Colluvium of Wyemaha formation, bearing the Churchill soil $(\mathrm{Qw}+\mathrm{C})$ (B horizon of the soil is partly eroded, the upper part of the Cca horizon is the white band in lower two-thirds of this layer, and the lower part of the Cca horizon extends into the Eetza formation); sand and gravel of lower member of Sehoo $\left(\mathrm{Qg}_{1}\right)$, locally bearing cellular tufa of this member; colluvium of middle tongue of Indian Lakes formation ( $\left.\mathrm{Qi}_{2}\right)$; and sand and gravel of dendritic member of the Sehoo $\left(Q_{s_{2}}\right)$, with dendritic tufa in its upper part (section 45, table 10), Gravel pit on north side of saddle between Eetza and Sehoo Mountains, at west end of Wyemaha Valley. Portion of face shown is about $15 \mathrm{ft}$ high. 
QUATERNARY STRATIGRAPHY

TABLE 4.-Principal differences in gravel units of the Sehoo formation

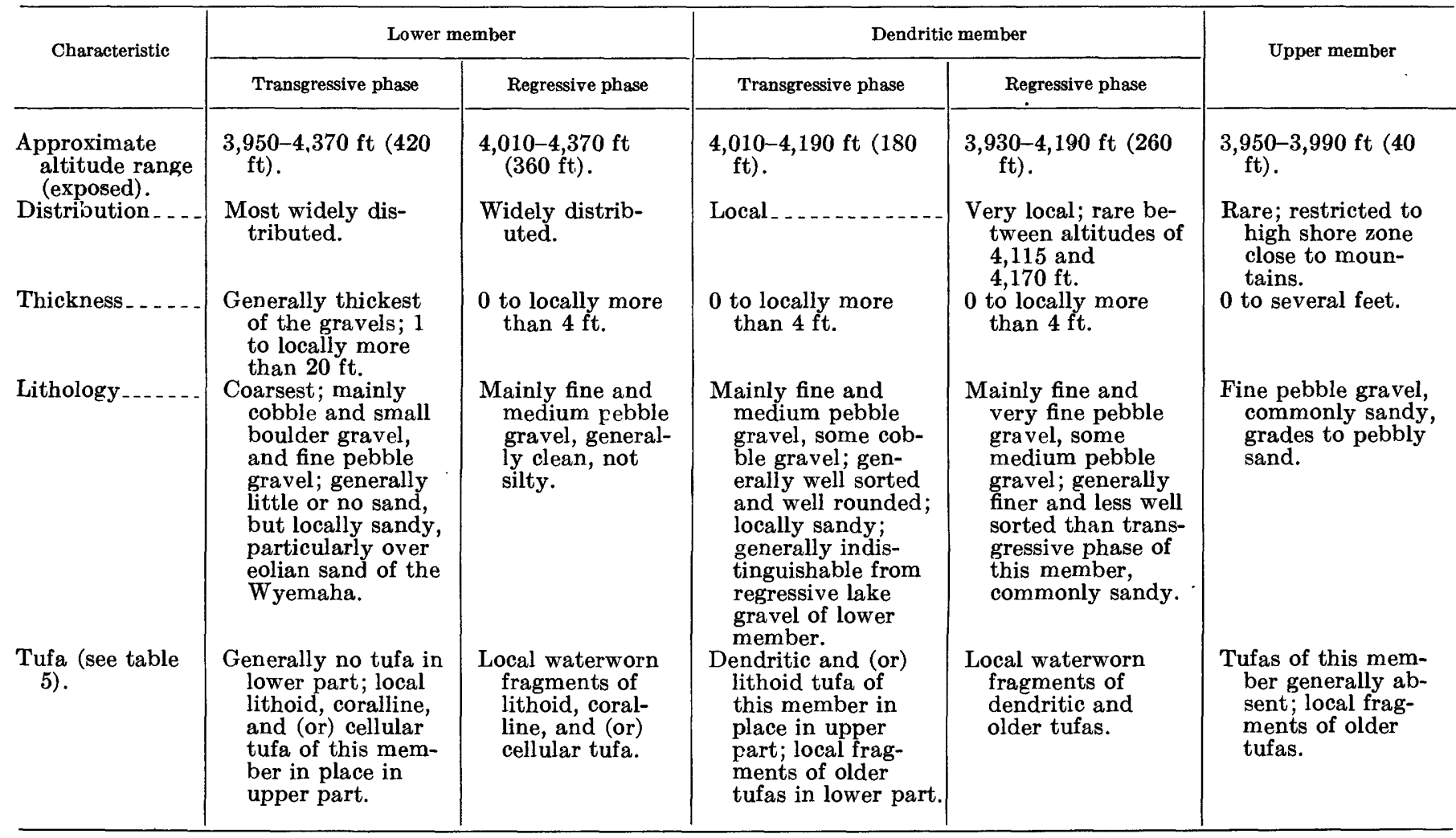

Clay of the Sehoo is by far the most extensively exposed map unit in the Lahontan Valley group, aggregating more than 100 square miles or about one-sixth of the lowlands of the map area. It is the predominant deposit exposed on the flats and dry-lake beds, and in Carson Sink it is continuously exposed over an area more than 22 miles in diameter extending many miles north and northeast of the map area. The best sections are exposed at the scarps of deflation basins and in drainage canals.

In the Carson Lake quadrangle the clay unit of the Sehoo normally extends no higher topographically than the base of the highland shores, at an altitude of about 3,965 feet (fig. $15 C$ ), and has an outer selvage of silt generally less than a quarter of a mile wide. which is transitional into the sand and gravel of the highland shores. In several of the intermountain saddles and at Hidden Cave, however, tongues one-half to 4 feet thick of silt, minor amounts of interbedded clay and sand, and locally limestone extend into the highlands as high as about 4,100 feet (pl. 8 and sections 39, 41, and 42, table 10): These tongues are offshore sediment laid down while the early and middle Sehoo lakes were at moderate to high levels. Typically they overlie transgressive and regressive gravel and sand of the lower member of the Sehoo, and are overlain by regressive gravel and sand of the dendritic member of the Sehoo.
In the Fallon quadrangle the clay unit reaches a maximum altitude of about 4,120 feet in highland embayments and progressively thickens toward the western part of the Carson River delta, the source area.

In the lowlands the clay unit is predominantly clay but also includes local thin beds and partings of silt, sand, limestone, tufa, and volcanic ash. It is relatively uniform in lithology, both vertically and laterally, except on the west delta of the Carson River and locally near highlands. The clay beds are silty clay to clay, in places very plastic when wet, and locally bentonitic. In the eastern half of the area the bedding is mostly indistinct and has faint lamination, though the uppermost and lowermost parts commonly are well bedded. Westward the bedding and lamination tend to become more distinct, and near Lahontan Dam (west of the map area) the lamination is locally varvelike. In fresh exposures the clay beds are generally very light olive gray to light yellowish olive gray $(5 Y 6 / 1,5 Y 6 / 2$, $5 Y 7 / 1$, or $5 Y 7 / 2$ ), locally medium to dark tan-gray, and light greenish gray to nearly white. The prevailing greenish tint is most apparent when the clay is moist, and helps to distinguish it from lake clays of the Fallon formation. Well drillers describe this clay in well logs as gray, yellow, and locally even blue and green. Relatively dried-out unslumped exposures generally show prominent prismatic jointing, and the clay 
LAKE LAHONTAN: GEOLOGY, CARSON DESERT, NEV.

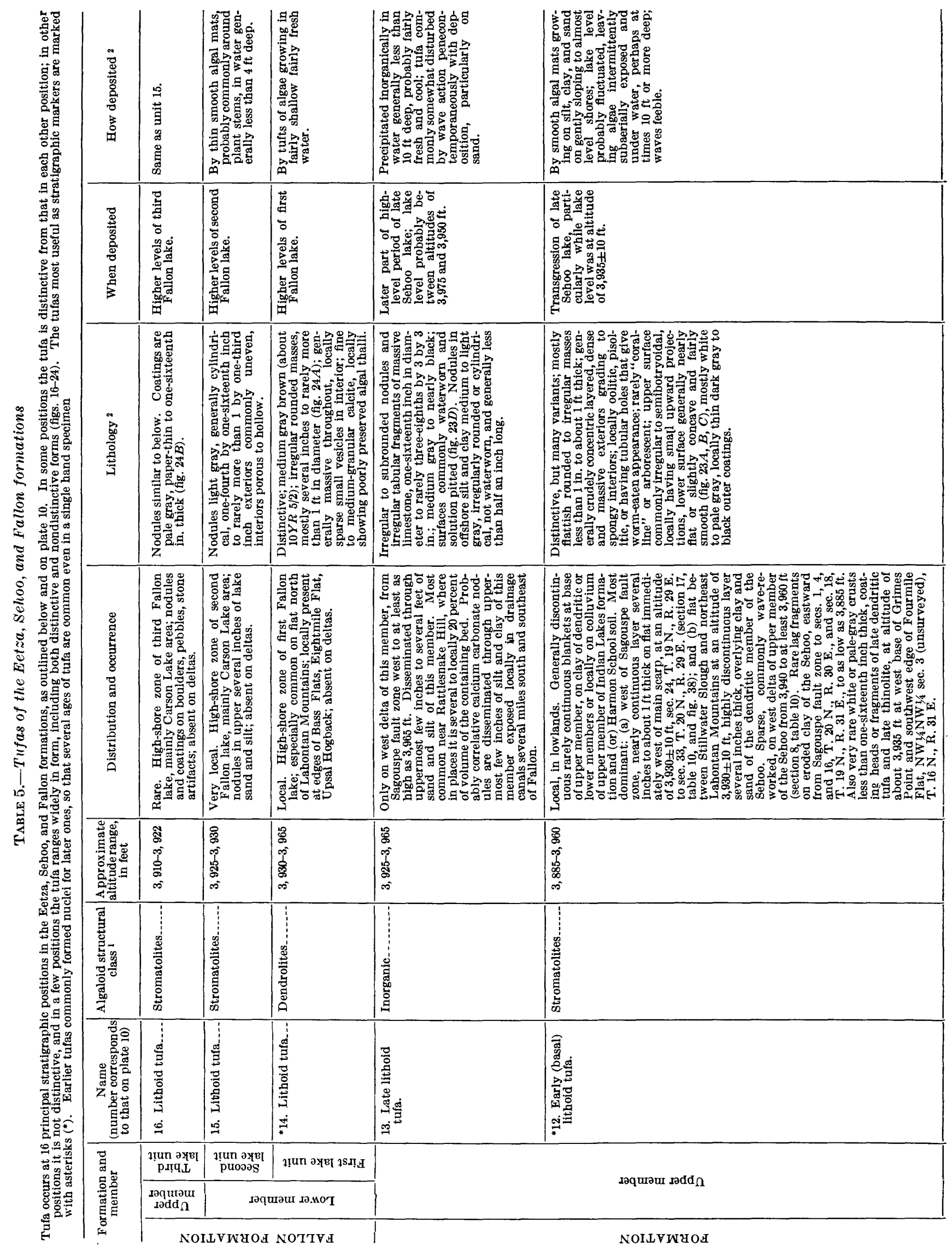


QUATERNARY STRATIGRAPHY

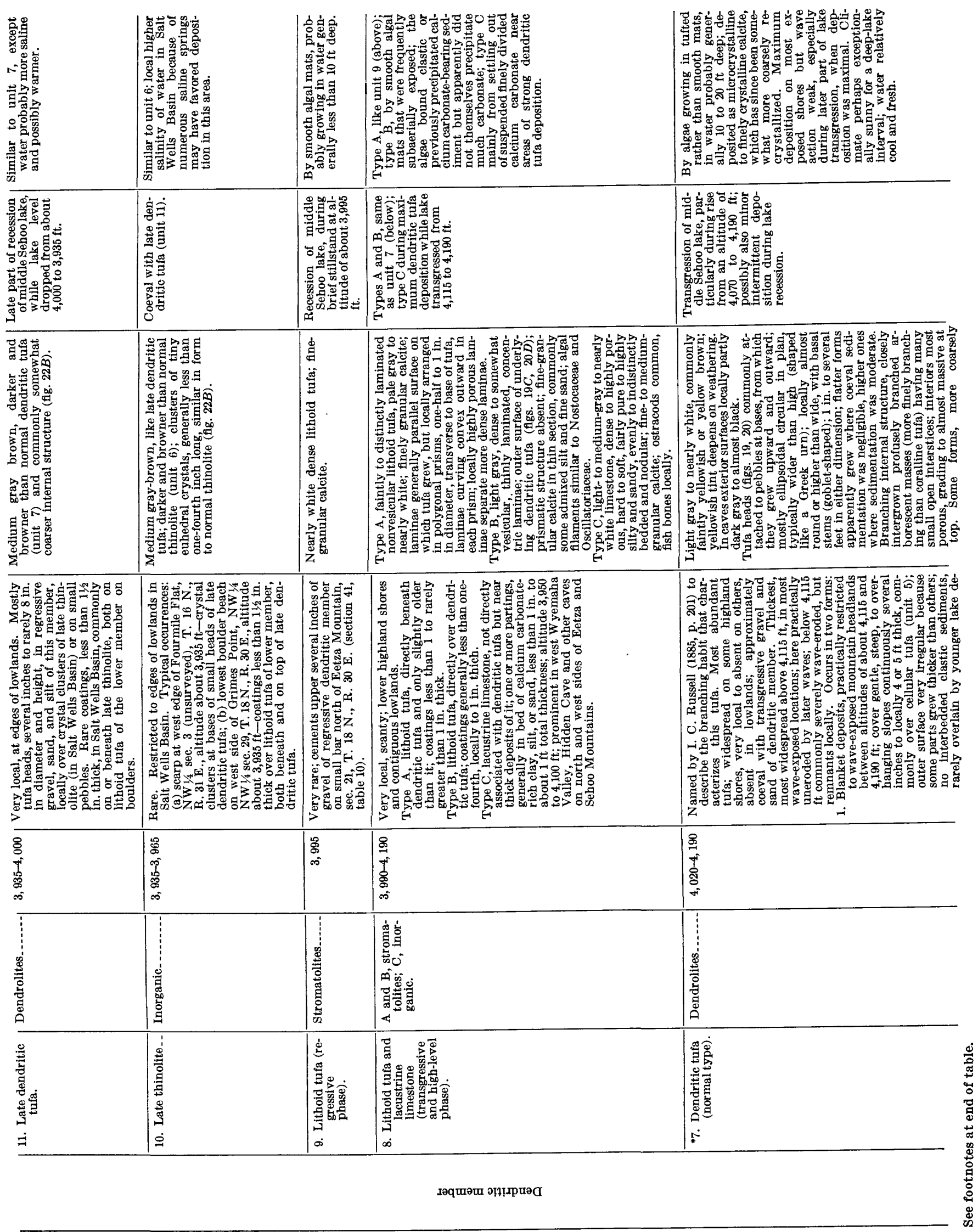




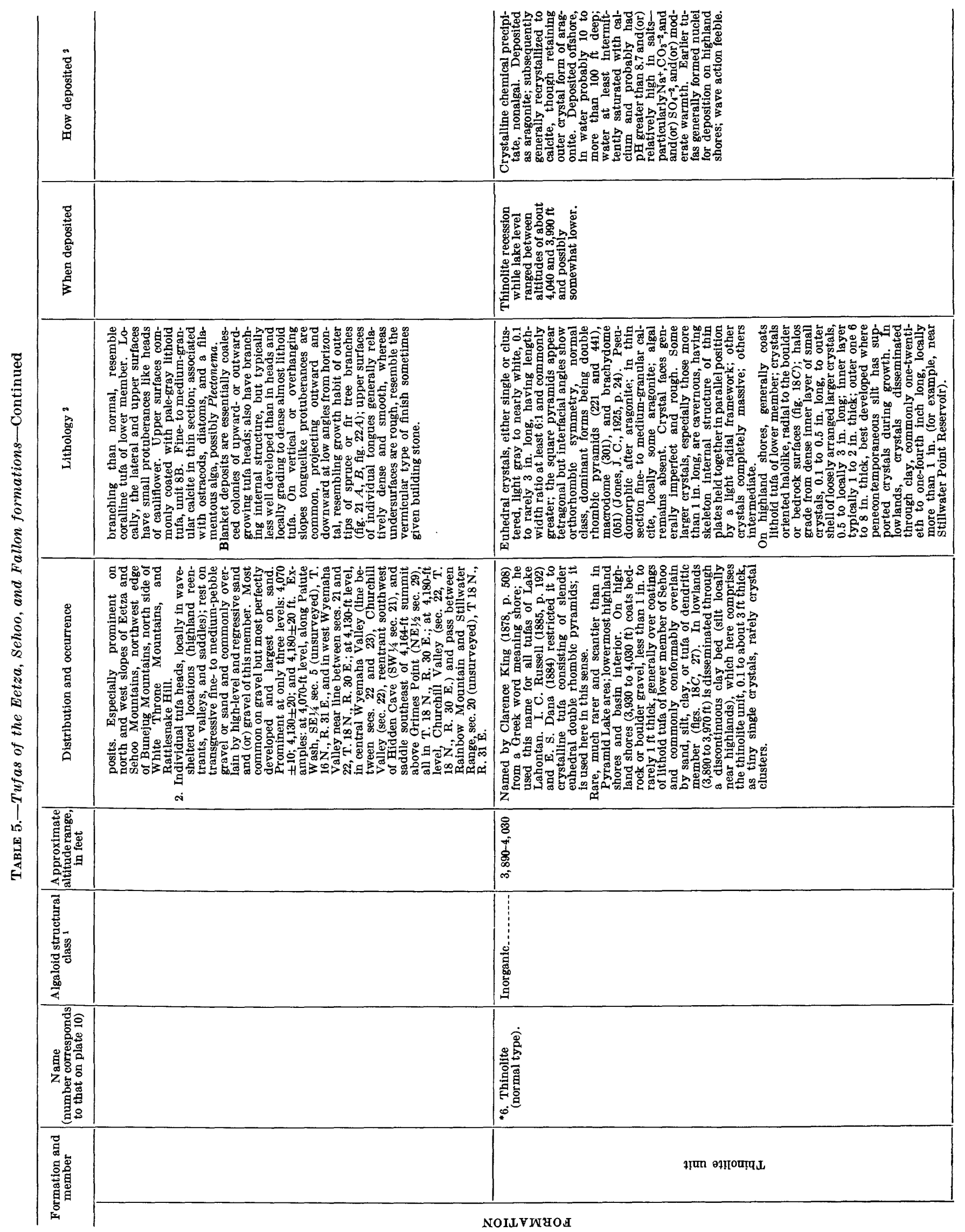


QUATERNARY STRATIGRAPHY

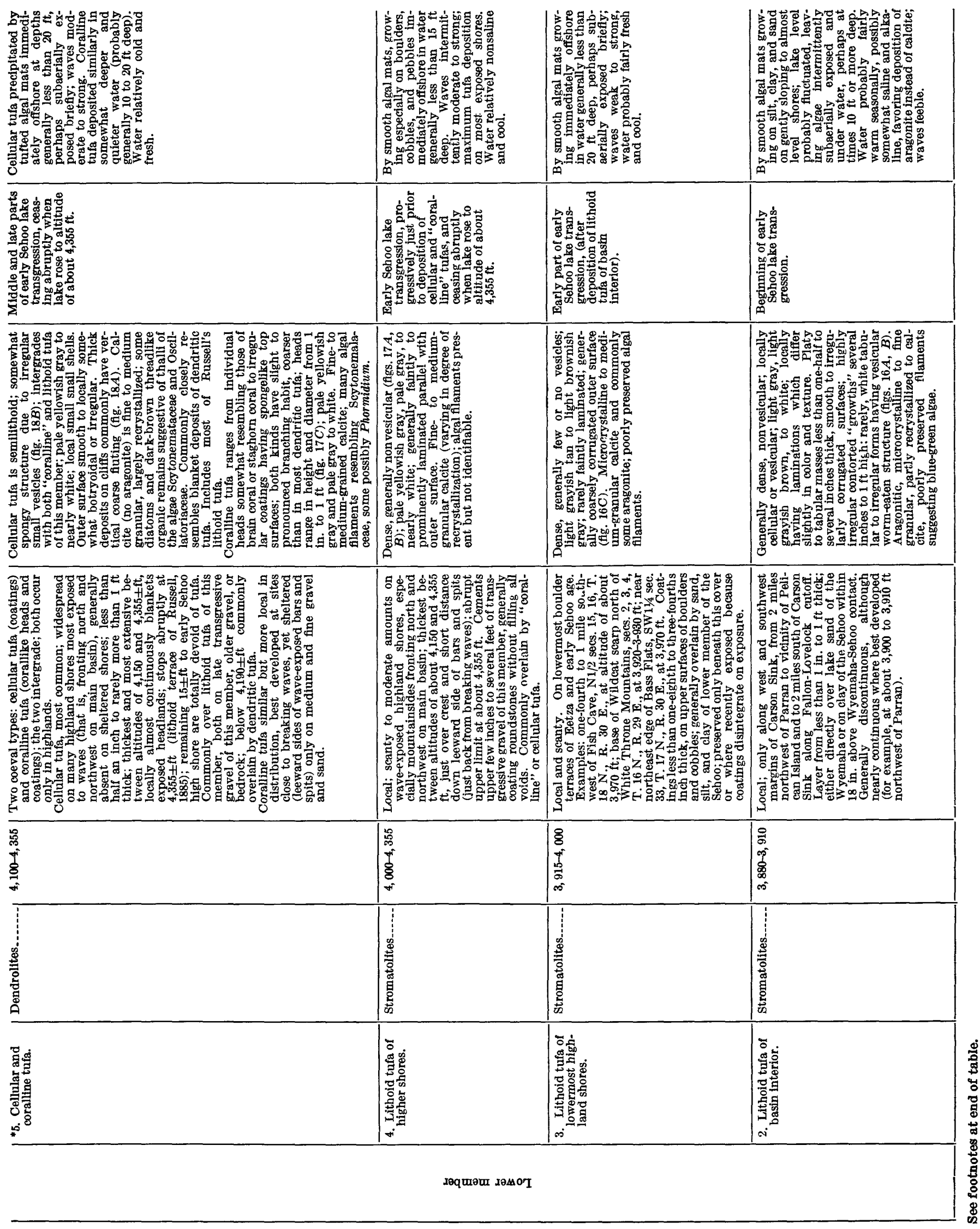


LAKE LAHONTAN: GEOLOGY, CARSON DESERT, NEV.

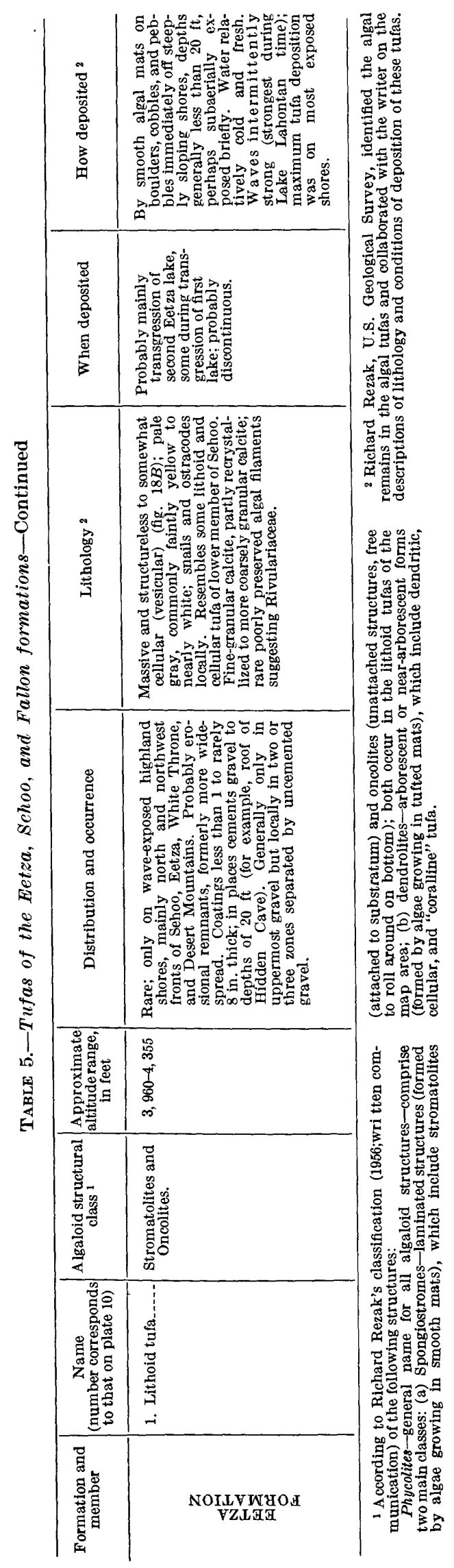


generally is compact, hard, and tough, normally breaking into irregular blocks bounded by joints and bedding laminae.

The full uneroded thickness of the clay unit ranges from about 5 to 20 feet in the eastern half of the lowlands; it is thickest in the Carson Lake, Stillwater Slough, and Stillwater Lakes areas-probably because these low areas acted as sumps for collection of sediment. In the western lowlands the unit thickens toward the west delta of the Carson River to commonly 30 and locally more than 40 feet in the upstream part; it is about 60 feet thick where exposed in bluffs and a dug well in secs. 4 and 5, T. 18 N., R. 27 E. Most exposures show only a fraction of these thicknesses because of widespread deflation.

In the upstream part of the west delta, west of Soda Lake and the Old California Trail, this unit occurs in two zones within the Sehoo formation, separated and overlain by sandy zones. The lower zone is the thicker of the two, more clayey (generally silty clay and clay), fairly coherent, and forms prominent scarps in deflation basins. The upper zone of the clay unit is mainly silt, relatively incoherent, and rarely forms scarps. These two zones are the high-stage deposits of the lower and dendritic members of the Sehoo, respectively (section 7 , table 10 ).

Most of the lake tufas for which Lake Lahontan is famous are in the Sehoo formation. Twelve principal varieties of tufa occur within the formation at nine distinct stratigraphic positions. They are described in table 5 (figs. 16-24) and their relations to the principal lake fluctuations are shown on plate 10 . The cellular and dendritic tufas are by far the most dominant; they are especially thick between altitudes of about 4,115 and 4,355 feet (dendritic tufa extends only as high as the maximum of the middle Sehoo lake, about 4,190 feet).

Russell's (1885) "lithoid" tufa is mostly in the lower member of the Sehoo ("lithoid tufa of the higher shores" and "cellular tufa"); minor amounts are in the Eetza formation. The distinction between lithoid and dendritic tufas is less definite than Russell implied, as all gradations exist between the two types. J. C. Jones $(1925$, p. 20$)$ found this also to be the case at Pyramid Lake. Russell thought that all the lithoid tufa was deposited during the first deep-lake period of Lake Lahontan, and conversely, he (1885, p. 114) considered the presence of lithoid tufa on high-shore gravel embankments as proof that they were formed during the first deep-lake period. This accounts in part for his error in interpreting the relative heights of the maximums of the lake during the early and late deep-lake periods (Eetza and Sehoo times of this re-
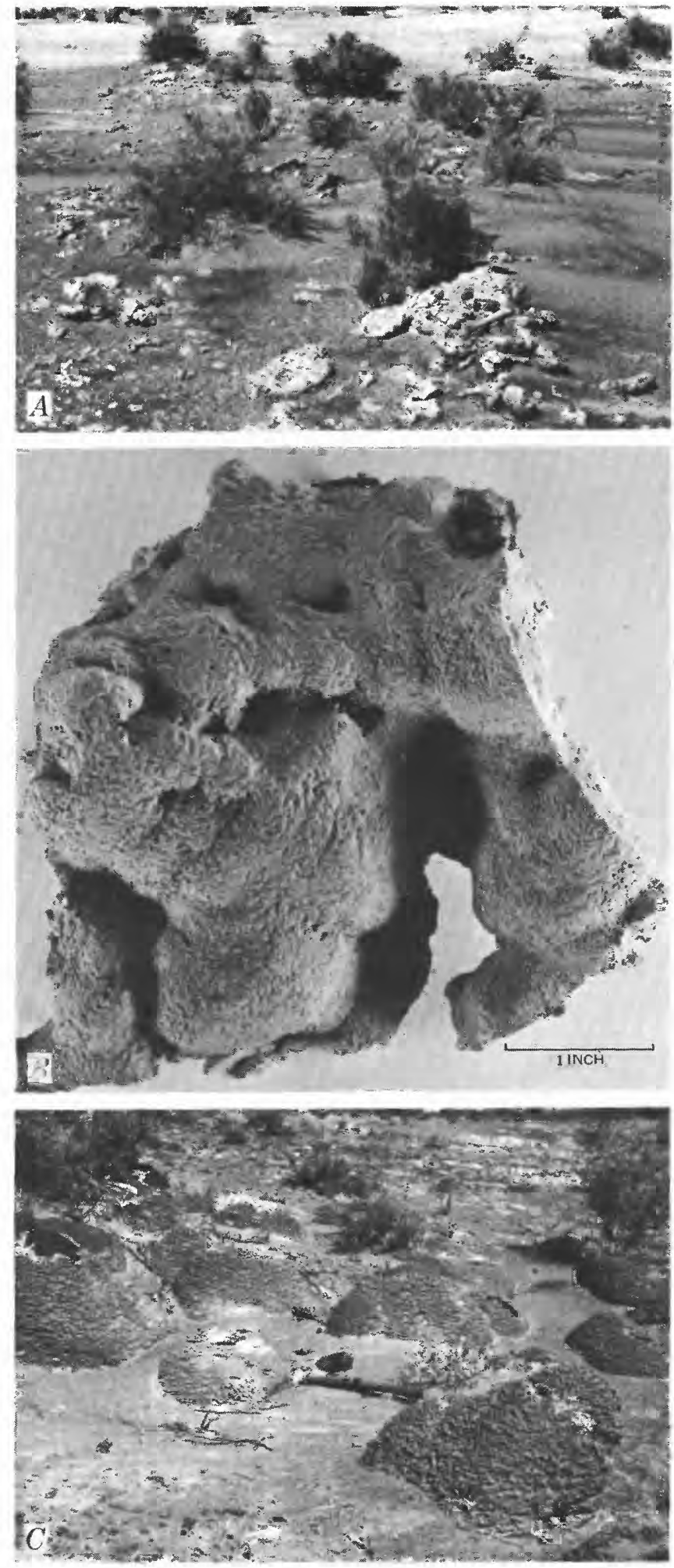

Figure 16.- $A$, Basin-interior lithoid tufa of lower member of Sehoo formation. Near south edge of Carson Sink, sec. 11, T. 21 N., $R$. 29 E. Pick is 18 inches long. $B$, Hand specimen of tufa from locality in $A$, showing typical shape and surface texture. Full scale. $C$, Lithoid tufa of the lowermost highland shores, of lower member of the Sehoo, coating boulders of Eetza formation. West edge of Sehoo Mountain, SE $1 / 4$ sec. 16, T. 18 N., R. 30 E. Pick is 18 inches long. 

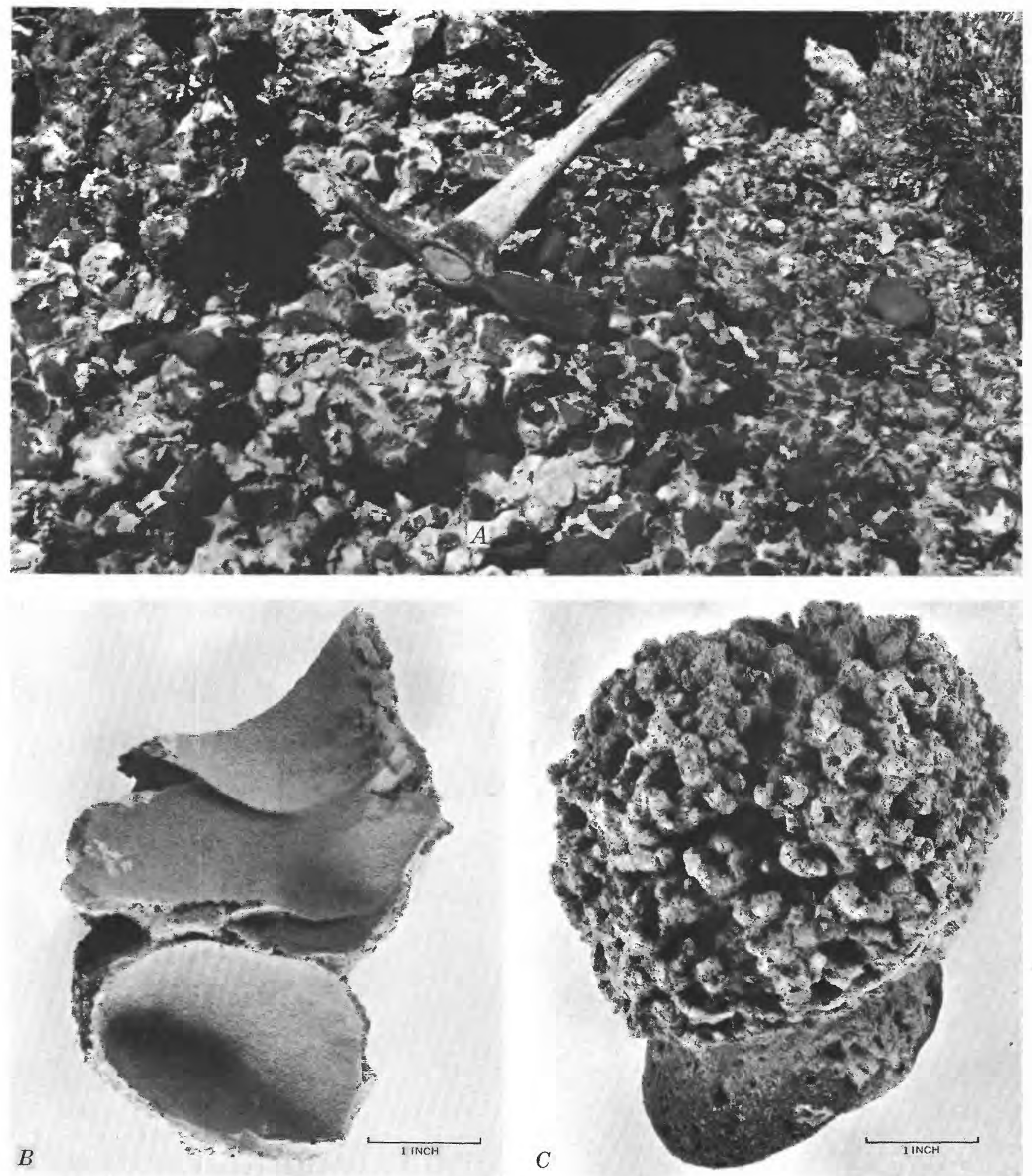

FIGURE 17.-A, Lithoid tufa of the higher highland shores, of lower member of Sehoo formation, cementing transgressive gravel of lower member. Northern Eetza Mountain, SW1/4 sec. 21, T. 18 N., R. 30 E.; altitude 4,240 feet. $B$, Hand specimen of tufa shown in $A$. Concave surfaces are impressions of pebbles that were cemented by the tufa. Full scale. $C$, Hand specimen of typical "head" of "coralline" tufa of lower member of the Sehoo. Full scale. 

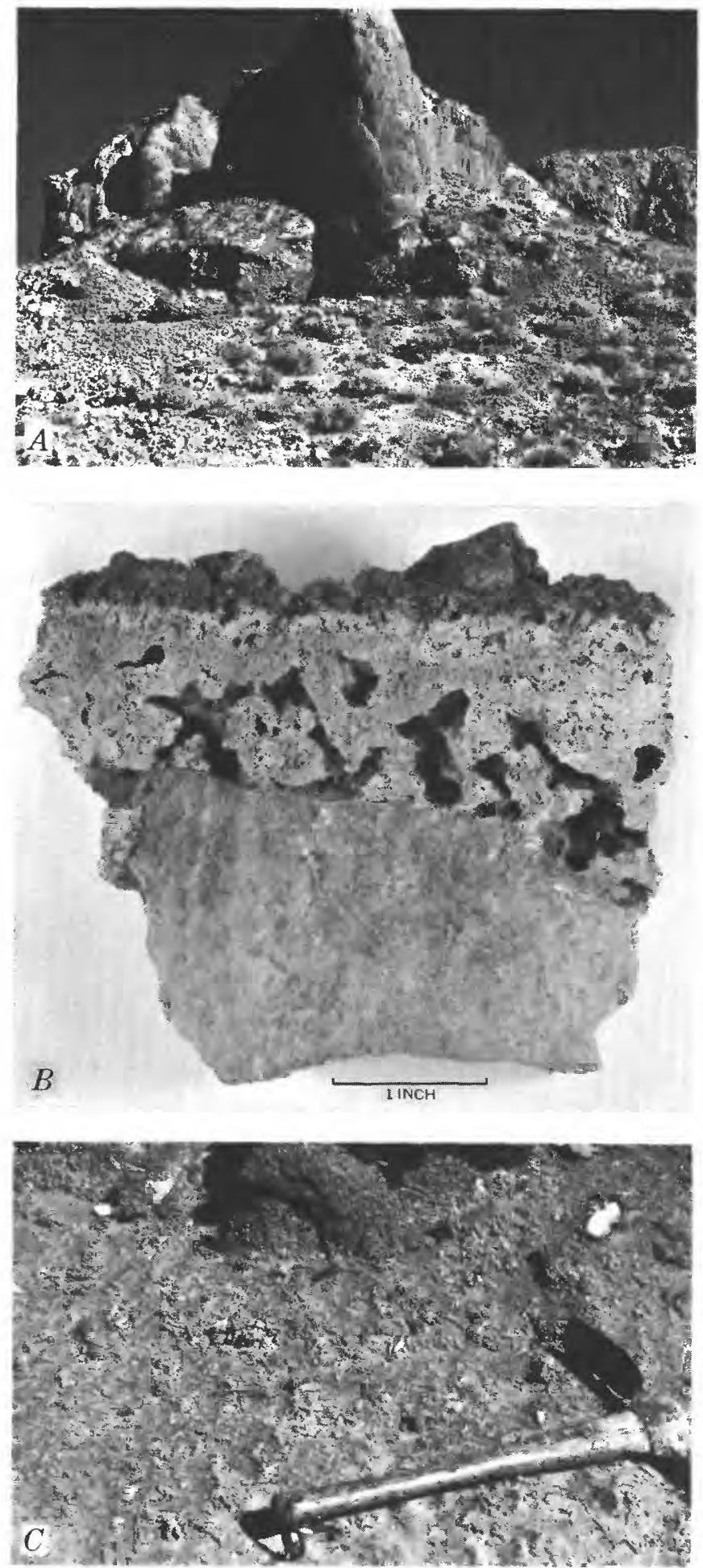

FIGURE 18.- $A$, "Tufa draperies" of cellular tufa of lower member of Sehoo formation typical of those formed on steep-sided prominences most exposed to waves, between 4,150 and 4,355 feet altitude. North edge of Desert Mountains, NW1/4 sec. 14, T. 16 N., R. 28 E. $B$, Hand specimen of cellular tufa on lithoid tufa of Eetza formation. Full scale. $C$, Crystal clusters of normal thinolite over boulder coated with lithoid tufa of the lowermost highland shores of lower nember of the Sehoo. West edge of Sehoo Mountain, about 3,960 feet altitude, $S E 1 / 4$ sec. 16, T. 18 N., R. 30 E. Graduations on pick handle are 1 inch apart. port). The evidence to support this conclusion is summarized on page 64,65 .

\section{MEMBERS}

The Sehoo formation intertongues with the subaerial Indian Lakes formation described below. The three main divisions of the Sehoo are each defined as a member of the formation (pl. 12) : the lower, dendritic, and upper members; these are believed to record the third, fourth, and fifth major deep-lake cycles, respectively, of Lake Lahontan. The three members reach altitudes of about $4,370,4,190$, and 3,990 feet, the maximums of the early Sehoo, middle Sehoo, and late Sehoo lakes, respectively. A thin, fourth unit characterized by thinolite tufa lies between offshore sediments of the lower and dendritic members. The members are not differentiated on the quadrangle geologic maps, although they are in the special large-scale maps (pl. 7 ; figs. $25,29,34$ ) and in many of the sections in table 10.

The lower and dendritic members are further separated, at altitudes above 3,990 feet, by the subaerial sediments of the middle tongue of the Indian Lakes formation and the unconformity that records subaerial erosion which locally represents this tongue marking a lake recession at least this low between the early and middle Sehoo lakes. The dendritic and upper members are similarly separated above 3,900 feet by the upper tongue of the Indian Lakes formation and by the unconformity and soil that locally represent this tongue, indicating recession at least this low between the middle and late Sehoo lakes.

\section{LOWER MEMBER}

The lower member of the Sehoo formation consists of lacustrine gravel, sand, silt, clay, tufa, and volcanic ash. It extends to an altitude of about 4,370 feet-the highest shoreline of the early Sehoo lake-about 10 feet below the Lahontan beach; this is considerably higher than the other members. It comprises about two-thirds of the uneroded volume of the whole formation. On highland shores this member is mainly sand and gravel, and a little tufa, silt, and clay, 1 to 50 feet thick; in the lowlands it is mainly clay and some silt, sand, tufa, and volcanic ash, and 1 to 30 feet thick, being thickest on the Carson River delta. The type locality is the site of section 34 (table 10), in Churchill Valley at an altitude of about 4,200 feet.

Gravel of the lower member is dominant along the main shorelines of the early Sehoo lake (pl. 9) and typically is thicker, coarser, and more widespread than the other gravels of the Sehoo (table 4). It ranges in thickness from 1 foot in sheltered reentrants to more than 30 feet in some spit embankments. On mountainous shores that were most exposed to waves, it is mainly 

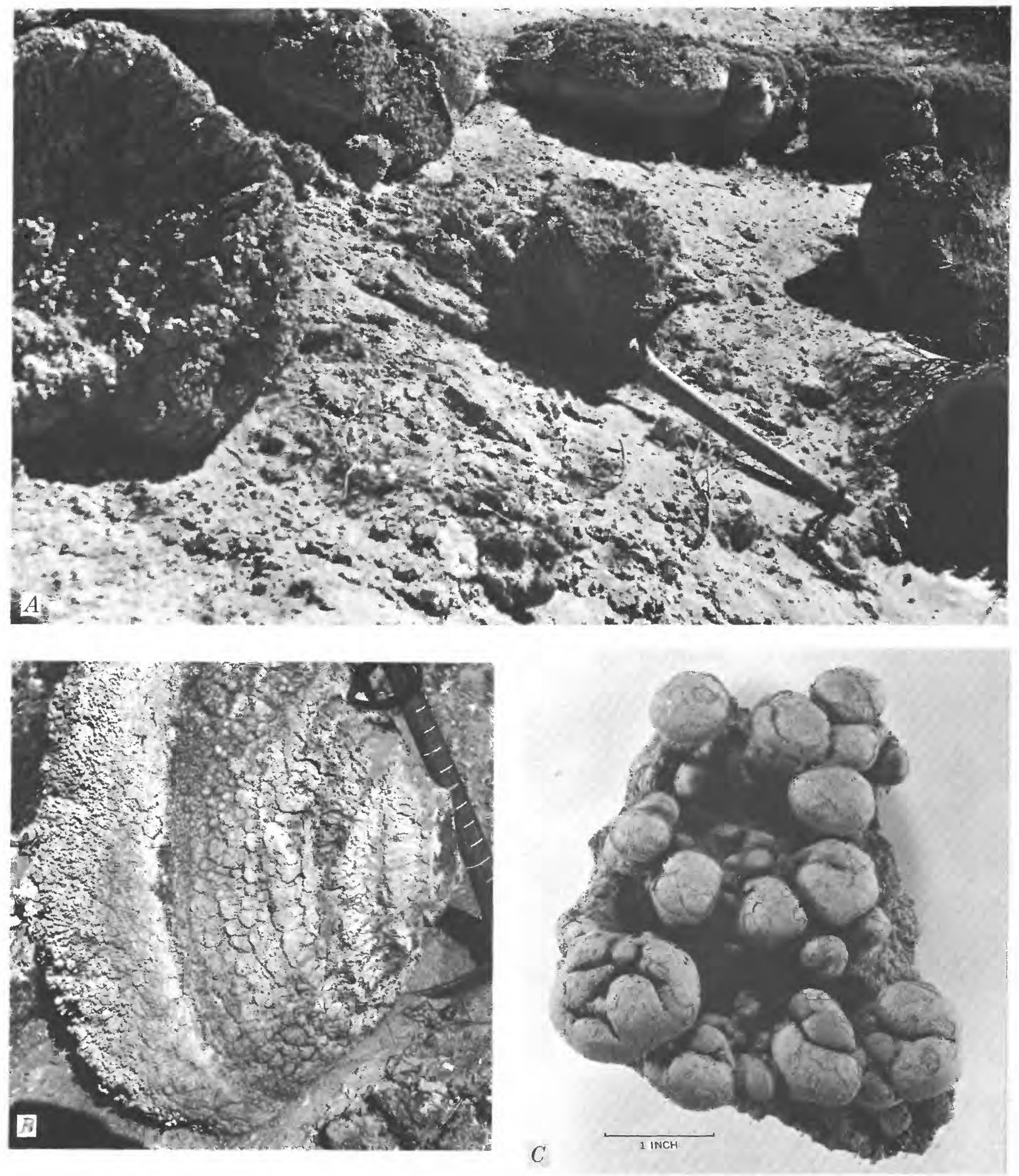

FIGURE 19.-A, Layer of "heads" of dendritic tufa of dendritic member of Sehoo formation developed on sand of lower member of the Sehoo. Bank of wash on piedmont northeast of Cocoon Mountains, E1/2 sec. 5 , (unsurveyed), T. 16 N., R. 31 E. B, Closeup side view of a "head" of dendritic tufa from exposure illustrated in $A$, showing characteristic conical shape of basal part, texture of outer surface, and pebble to which base of "head" is attached. Graduations on pick handle are 1 inch apart. $C$, Hand specimen of small "heads" of dendritic tufa growing upward from slab of lacustrine limestone. Largest "head" is about 2 inches in diameter. Note spalls of concentric thinly laminated lithoid tufa on outer surfaces of tops of heads. 

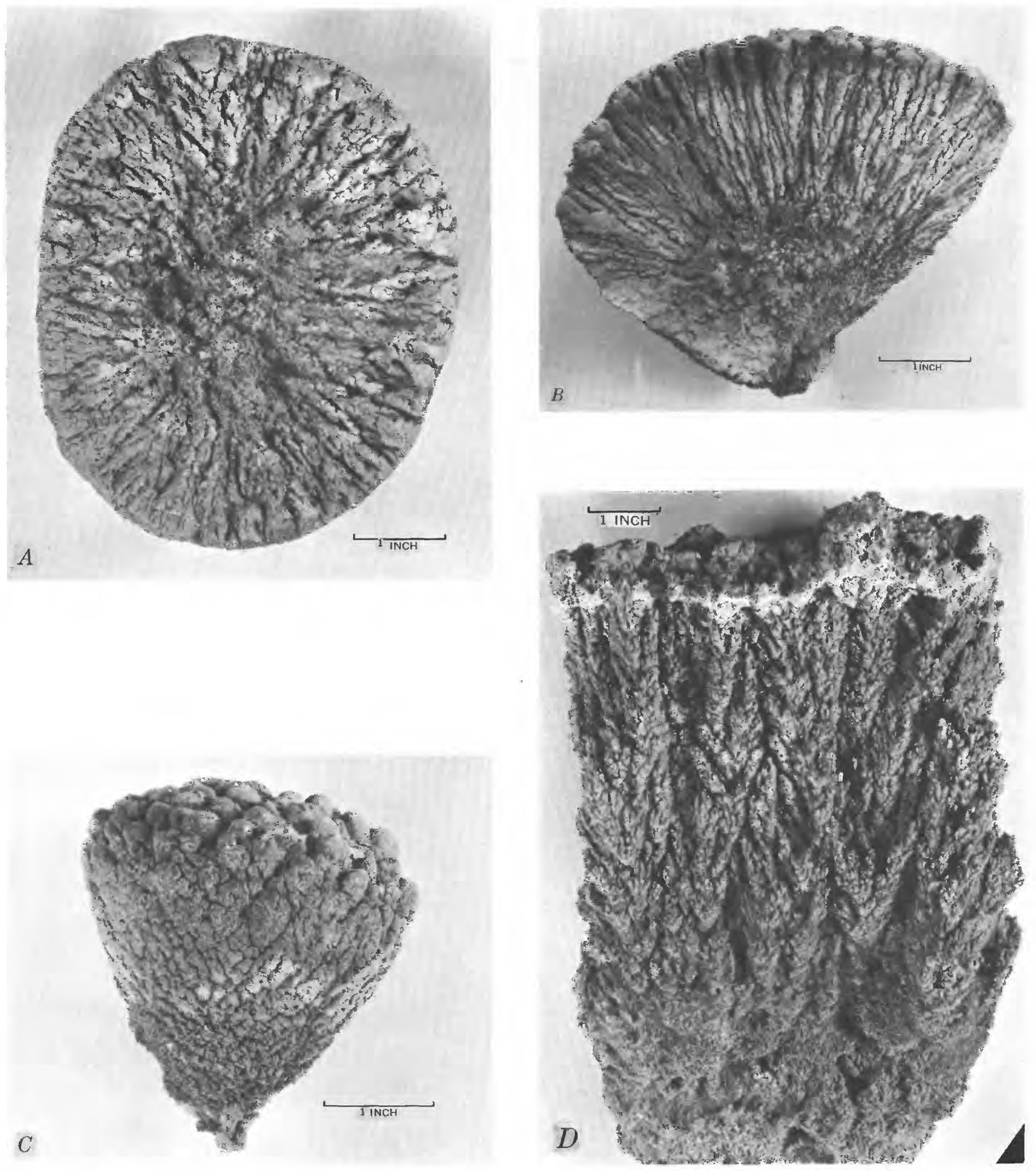

FigURE 20-Dendritic tufa dendritic member of Sehoo formation $A, B$, $C$, tufa "heads" showing internal structure $A$, is a horizontal section; $B$, a transverse section; and $C$, an exterior side view. $D$, shows transverse section through a mass that grew as a continuous coating vertically upward from a gravel bar (not as a tufa "head"); lithoid tufa (also of the dendritic member) coats the upper surface. 

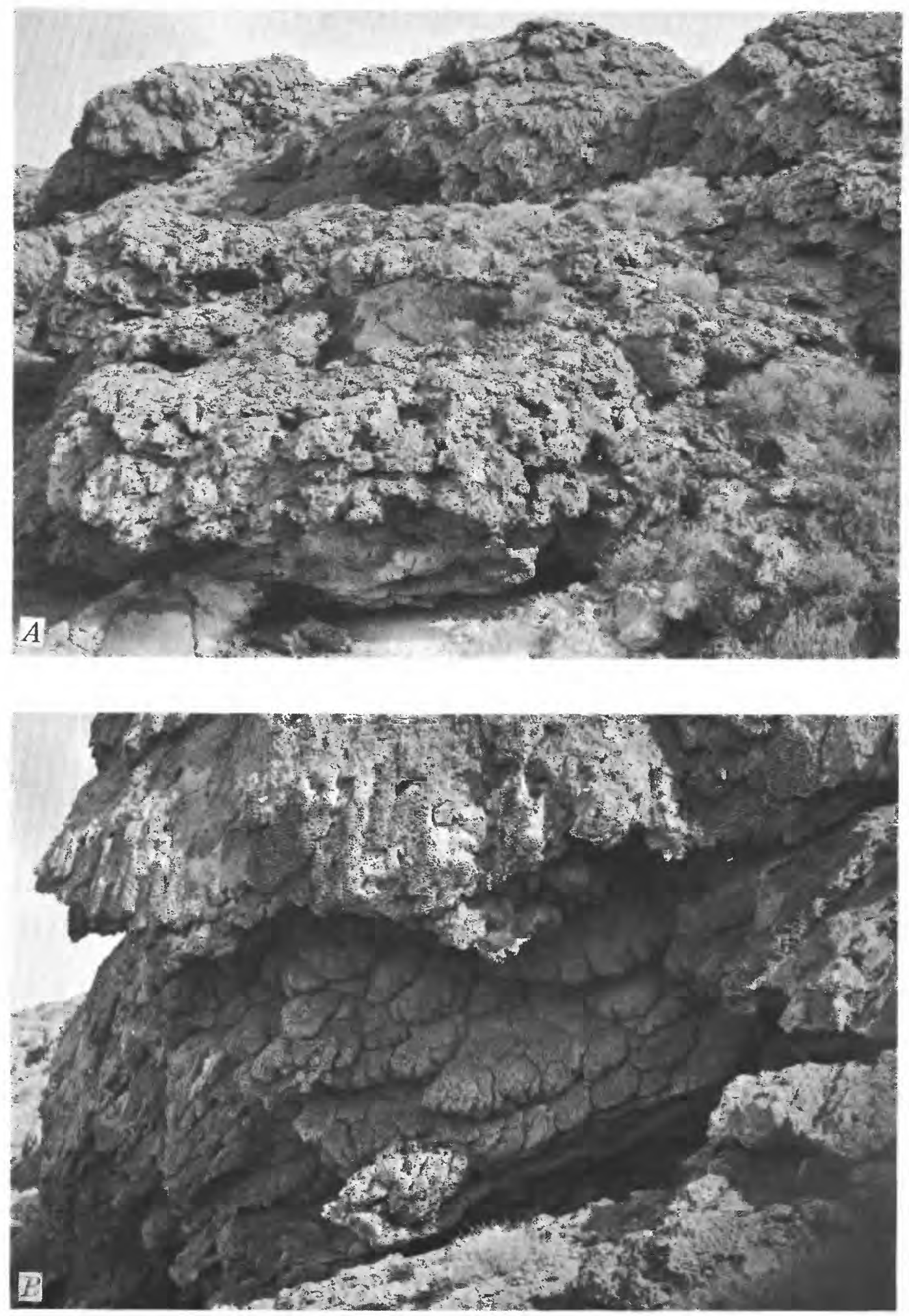

FIgure 21. $-A$, Thick blanket deposits of dendritic tufa. Northern Eetza Mountain near Hidden Cave. $B$, Closeup showing structure of dendritic tufa on a cliff at locality shown in $A$. 

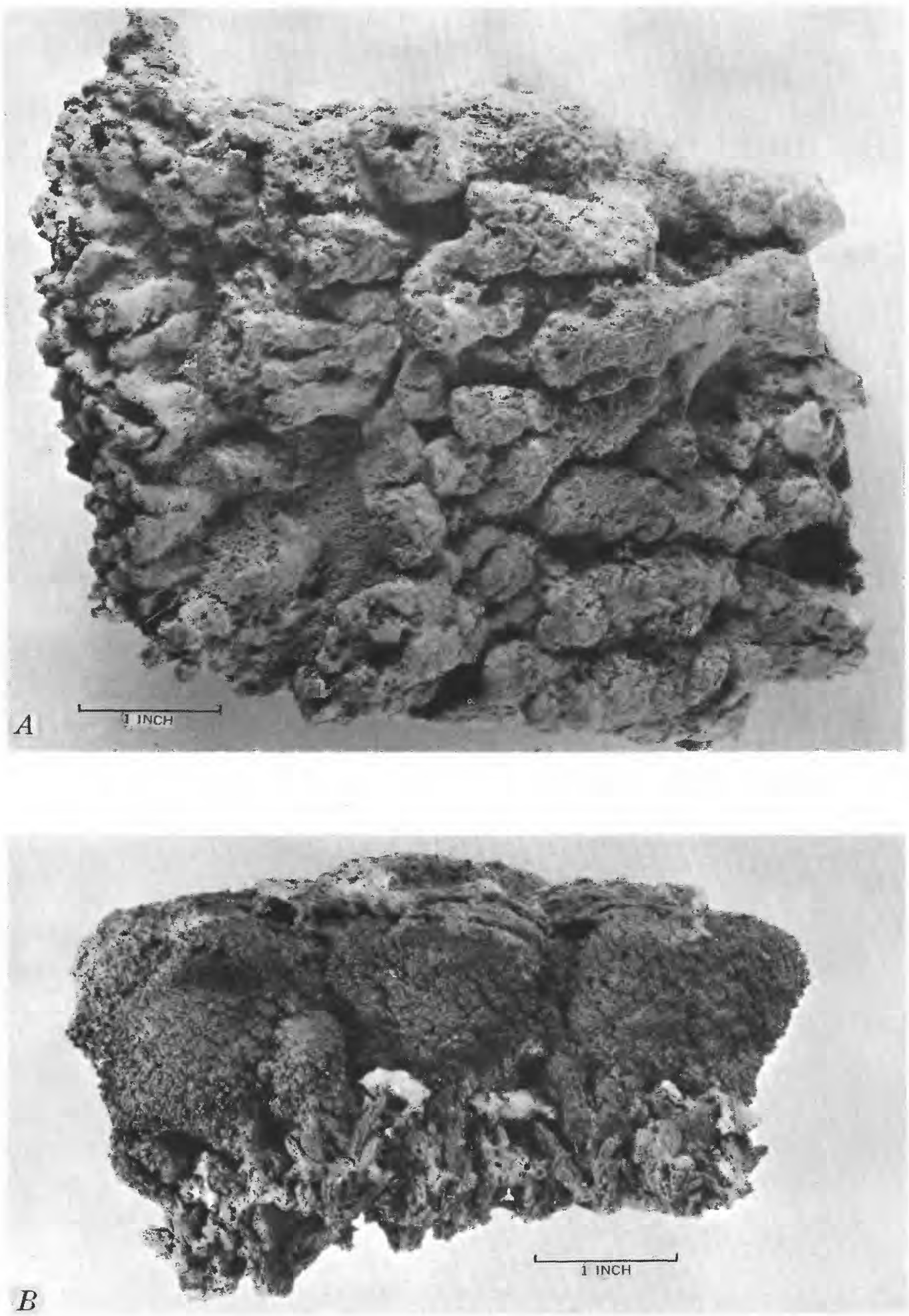

FIGURE 22.-A, Hand specimen of dendritic tufa from locality shown in figure 21, showing details of exterior texture of downward-facing part of the tufa "branches." $B$, Late dendritic tufa "heads," resting on late thinolite and overlain by a layer of lithoid tufa; all belong to the late regressive phase of dendritic member of Sehoo formation. 

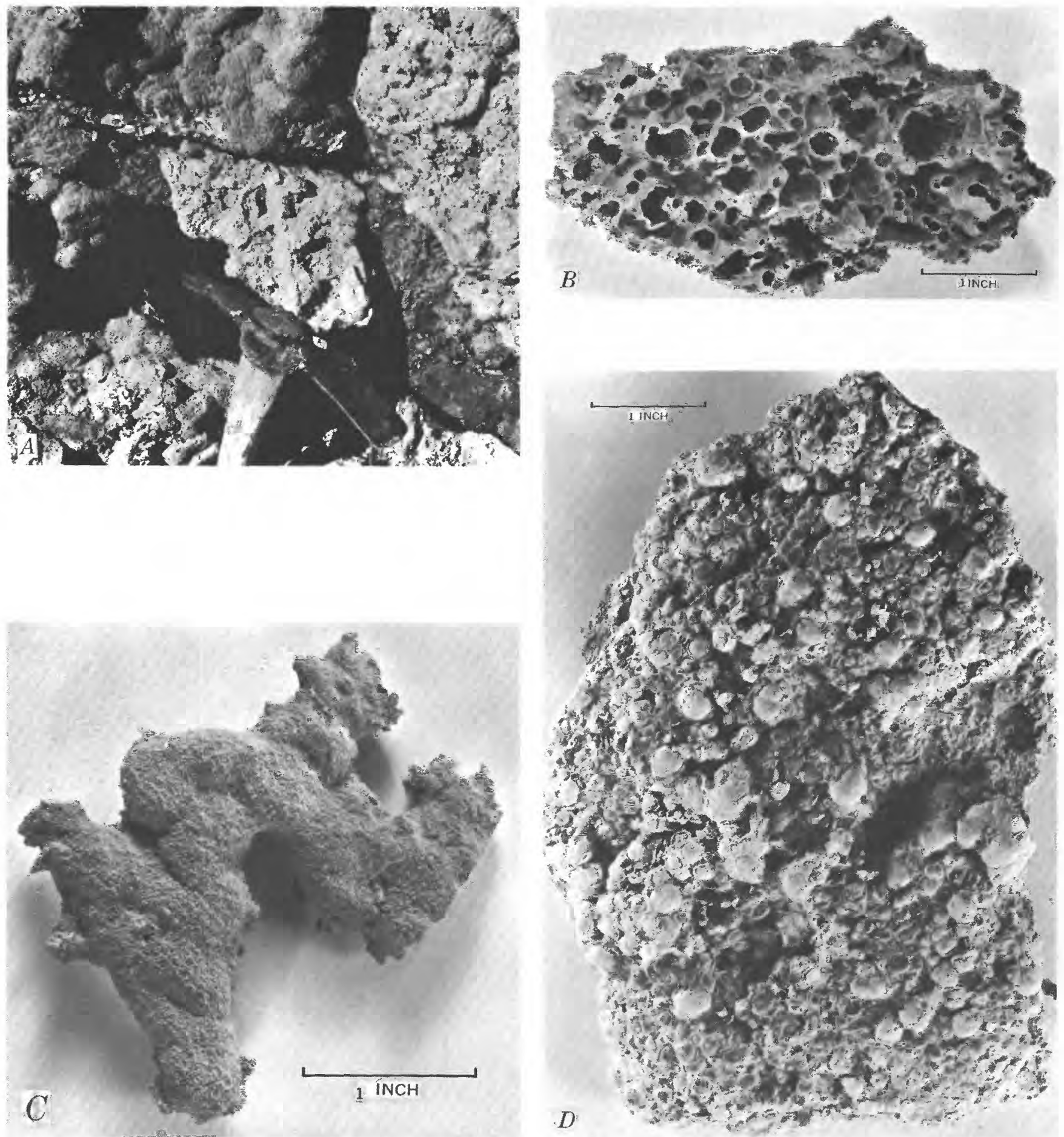

Figdre 23.-A, Early lithoid tufa of upper member of Sehoo formation, showing typical surface structure; white piece in center shows bottom surface; others show top surfaces. 0.6 mile north of Harmon School, 3,930 feet altitude. $B$, $C$, Hand specimens of other variants of this tufa. $D$, Late lithoid tufa of upper member of the Sehoo. 

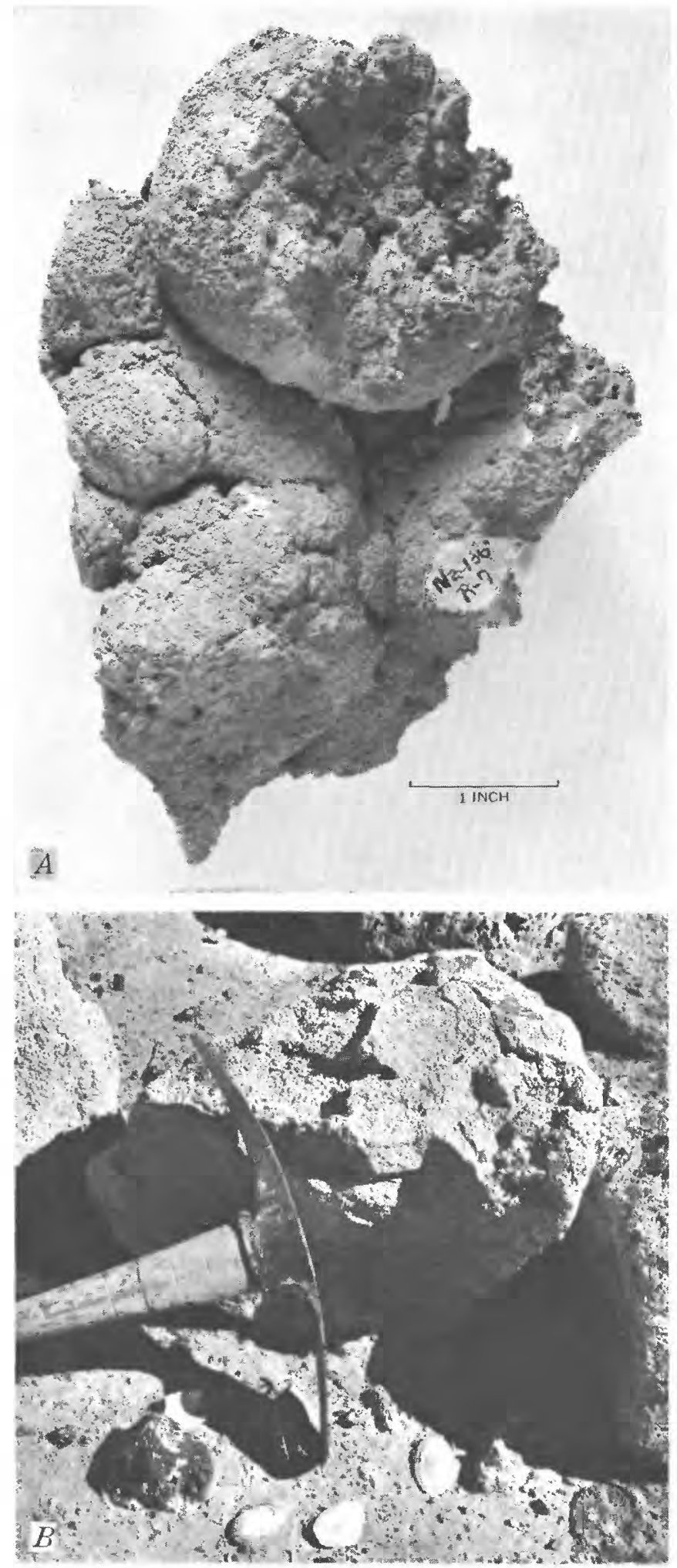

FIGURE 24.-A, Lithoid tufa of first lake unit of Fallon formation. Hand specimen. A distinctive marker. $B$, Lithoid tufa of third lake unit of Fallon formation. The coatings are so thin that they do not conceal the vesicles on the surfaces of the basalt boulders. Note also the clam shells, Anodonta caiforniensis, characteristic of the high-shore of the third Fallon lake. W1/2 sec. 29, T. 17 N., R, 30 E., about 3,915 feet altitude. boulder and cobble gravel; in sheltered valleys and intermountain saddles, it is cobble and pebble gravel (fig. 15A). The gravel is mostly reworked older gravel; only a small amount came from wave erosion of bedrock as shown by the paucity of rock-cut scarps and benches of early Sehoo age (p. 63-64).

In places transgressive and regressive phases of gravel of the lower member of the Sehoo can be distinguished, especially where they are parted by sand, silt, clay, or tufa. The transgressive gravel is generally coarser and thicker than the regressive gravel (table 4).

Sand is more widespread than gravel in the lower member, primarily because of the abundant eolian sand of the Wyemaha formation from which it is mainly derived. Sand is especially dominant in intermountain saddles and passes such as Wyemaha Valley, the saddle between Rainbow Mountain and the Stillwater Range, and Simpson Pass. Here it normally is 1 to 10 feet thick, and rarely as much as 35 feet thick in valleys. It intertongues with silt and clay far out into the basin on the Carson River delta west of Fallon, but elsewhere this intertonguing is close to the foot of the hillshores and is not present in most of the basin interior except as local partings (p.59).

Transgressive and regressive phases can be distinguished locally, especially where gravel, clay, or tufa separates the two sands. Only transgressive sand occurs below an altitude of 3,990 feet, which is the approximate lower limit of the thinolite lake recession.

This unit is mostly fine to medium sand, loose and uncemented, well sorted, well to indistinctly bedded, and pale yellowish gray to very pale yellow. Locally it contains a little gravel, as below gravel bars overlying eolian sand of the Wyemaha formation. Some thicker deposits in valleys contain interbeds of lighttan and brownish-tan to brown-gray silt and silty clay. A pale-greenish-gray to white ash bed, half an inch to 20 inches thick, occurs in the lower part of the sand below an altitude of about 4,100 feet in valleys in the northeast Bunejug Mountains; it may correlate with the main ash bed near the base of the clay of this formation (p. 59). Ostracodes are common, and form a coquina in some layers.

Where this sand overlies eolian sand of the Wyemaha formation it commonly is difficult to draw a sharp boundary because exposures rarely are good enough to show the lower limit of the zone of lake reworking.

Clay of the Sehoo formation is largely in the lower two members and the thinolite unit, for the upper member is generally sand. The lower members are represented by zones of slightly differing lithology but the differences between members generally are not sufficiently pronounced to permit exact differentiation of the 


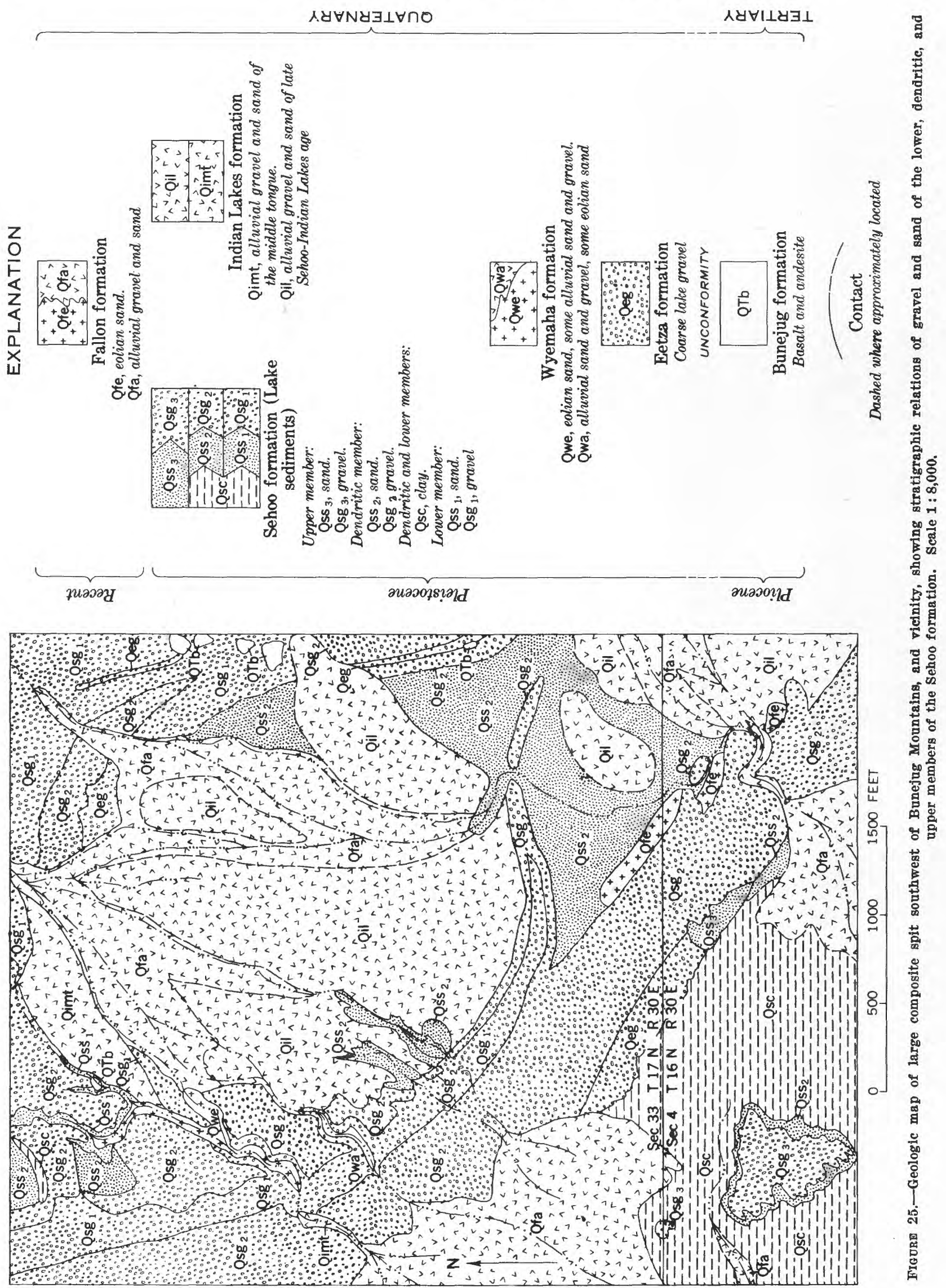


members where the thinolite unit (which is most distinctive) is absent (for example see sections $23,24,29$, and 35 , table 10 ). In general, the lower member represents about two-thirds of the original (uneroded) thickness of the clay, the dendritic member about onethird, and the thinolite unit less than one-tenth, but wide variations from these ratios occur locally.

Clay of the lower member ranges from about 3 to 15 feet thick in the eastern part of the lowlands and is more uniform in lithology than clay of the thinolite unit and the dentritic member. It is generally somewhat silty, but has local partings and interbeds of silt, volcanic ash, sand, and tufa in the lower part. It is practically nonsaline and is noncalcareous except for local disseminated calcium carbonate nodules and oolites in the upper several feet, just below the thinolite unit, and for local laminae of ostracode-bearing clay and ostracode coquina in the lower few feet. A layer of tufa ("basin-interior lithoid tufa," table 5), 1 inch to 1 foot thick, occurs locally about 1 to 2 feet above the base of the clay near the west and southwest edge of Carson Sink.

In the northern part of the Stillwater quadrangle the lower 4 to 9 feet of the clay has a few partings and thin beds of sand and volcanic ash, illustrated by section 4 (table 10). Beds 5, 7, 9, 11, and 13 in this section generally persist for several miles southward from the south edge of Carson Sink (fig. 26). The two main sand beds, 5 and 9 , have considerable olivine and andesitic or basaltic fragments in addition to quartz (bed 9 also has abundant ostracodes). The clastic rocks probably are pyroclastic air-fall deposits from small eruptions at the Upsal Hogback or Soda Lake vents. Volcanic ash beds 11 and 13 are one-eighth inch or less in thickness and seem to be local near the south edge of Carson Sink. Bed 7 , however, is $1 / 2$ to 8 inches thick and much more widespread. It is exposed locally at the southeast edge of the clay flat south of Stillwater Point Reservoir and at the north edge of Eightmile Flat, near the east boundary of the Carson Lake quadrangle; it has been penetrated in boreholes in southcentral and southeastern Carson Sink, and near the Stillwater Lakes, Indian Lakes, Stillwater Point Reservoir, Stillwater Slough, and Carson Lake. It is purewhite well-sorted pumiceous ash of very fine sand to fine-medium sand grade size, uncemented to locally hard cemented. It is the most distinctive stratigraphic marker in the clay of the Sehoo; moreover, because it came from a single eruption, it represents a single time interval wherever it is found. About 6 to 7 feet of clay of the Sehoo underlies the ash near the south margin of Carson Sink, but only 0 to 2 feet near the south edge of the main basin. Mono Craters, Calif., is the 695-383 0-64-5 most likely source for this and the other pumiceous ash beds (Russell, 1885, p. 141).

\section{THINOLITE UNIT}

The thin local thinolite unit of the Sehoo formation is characterized by the crystalline tufa known as thinolite and differentiated only where this tufa is present. It also contains lake clay and silt locally, but almost no sand and no gravel. Thinolite is described in table 5; it occurs in the lowlands and lowermost highland shores, between altitudes of about 3,890 and 4,030 feet, either as coatings a fraction of an inch to rarely 1 foot thick on gravel or bedrock, or disseminated through several inches to several feet of clay or silt. Nearly all the thinolite is in this unit, but a little occurs rarely in the dendritic member (table 5, pl. 10).

The type locality for the thinolite unit, showing stratigraphic relations and typical lithology, is at Wildcat scarp in the SE1/4 sec. 4, T 16 N., R. 29 E. (fig. 27). Sections 24, 29, and 35 (table 10) illustrate its relations in the lowlands.

Clay of the thinolite unit is a layer of thinolitebearing clay, from an inch to about 4 feet thick. The thinolite crystals are slender double orthorhombic pyramids of calcite (pseudomorphic after aragonite), occurring either singly or in small clusters. They gen. erally are sparsely disseminated through the clay, but locally are fairly abundant. Generally they are less than $1 / 8$ inch long by $1 / 32$ inch thick; locally they are bigger, rarely as much as $21 / 2$ by $1 / 4$ inch. Commonly small calcium carbonate nodules and oolites are associated with the thinolite, but the thinolite is more restricted vertically. The clay in this layer resembles that of the lower part of the dendritic member, rather than that of the lower member.

Clay of the thinolite unit has been identified only locally in the area underlain by clay of the Sehoo, between altitudes of about 3,890 to possibly 4,000 feet, from near the north edge of the Lahontan Mountains northeastward to Stillwater Slough and the flats east of the Stillwater Lakes; it extends several miles beyond the east edge of the Stillwater quadrangle. The clay is rarely exposed but its subsurface extent has been traced by auger holes. It is exposed locally at the west margin of the clay flat south of Stillwater Point Reservoir, on the shores of this reservoir, and in the U.S. Fish and Wildlife Service canals north of this reservoir; usually large thinolite crystals occur at the latter two places.

Loose crystals and crystal clusters of thinolite, resting on eroded clay of the lower member of the Sehoo, occur locally in an area extending about 7 miles southward from Carson Sink and at least 2 miles westward 


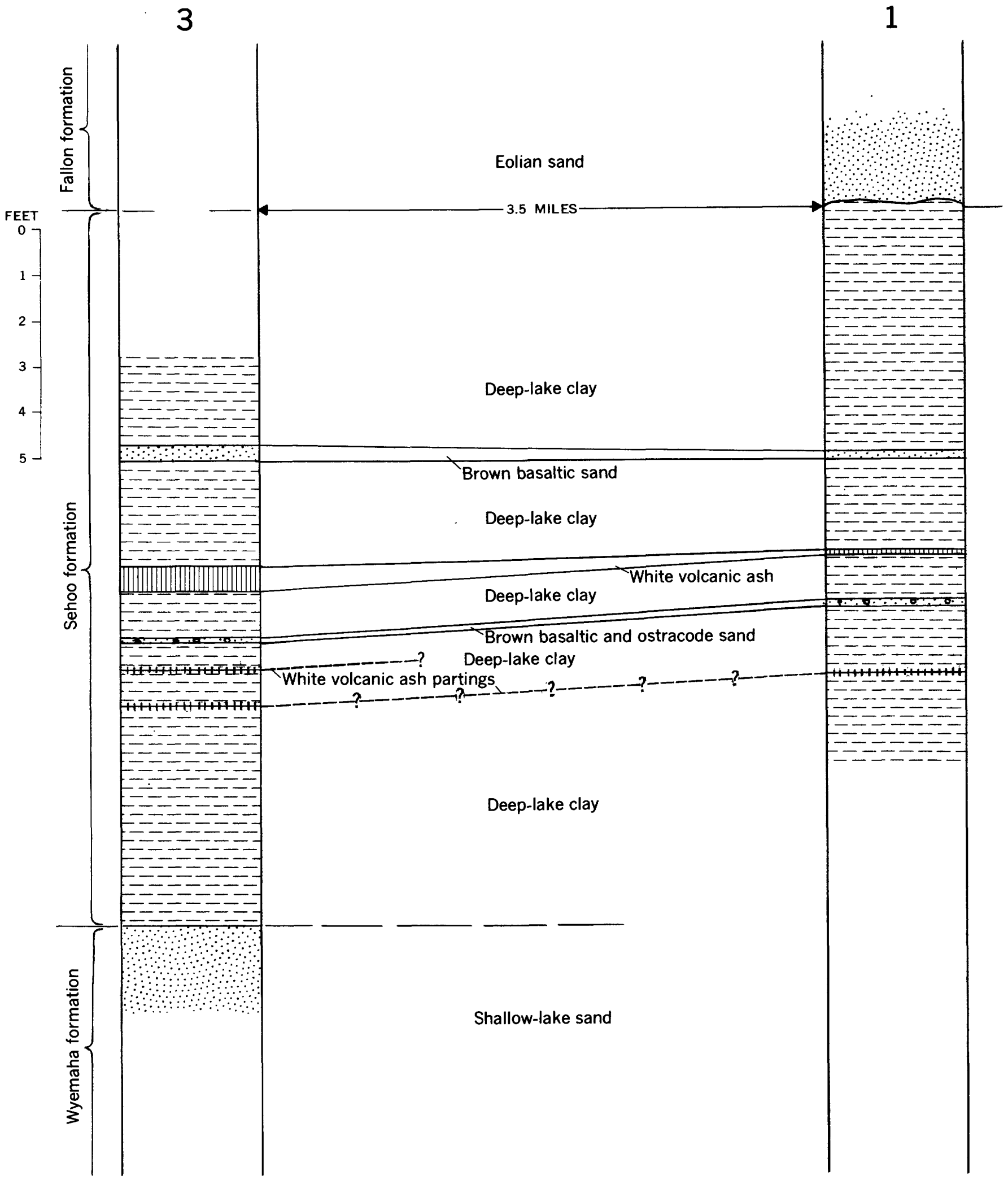

TIGURE 26. - Comparative columnar sections of clay of lower member of Sehoo formation, 31/2 miles apart, near south margin of Carson Sink, showing lateral persistence of basaltic sand and pumiceous ash beds and partings. Figure over columns refers to numbers used in table 10. 


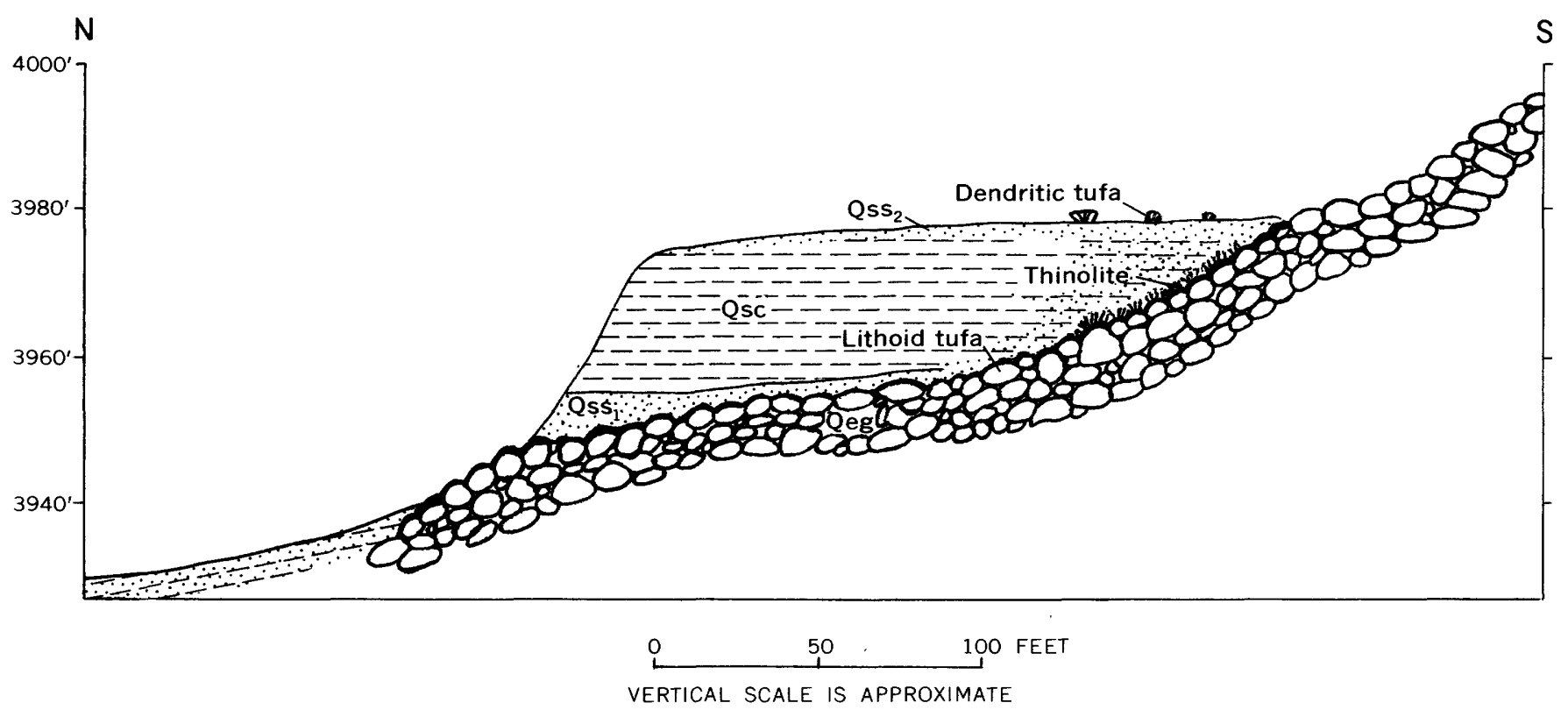

Fiadre 27.-Diagrammatic cross section showing occurrence of thinolite at Wildcat scarp, north of the White Throne Mountains, $\mathrm{NW} 1 / 4 \mathrm{SE} 1 / 4$ sec. 4, T. $16 \mathrm{~N}$., R. $29 \mathrm{E}$. Lithoid tufa of lower member of Sehoo formation thinly coats boulder gravel of Eetza formation (Qeg). Clusters of thinolite crystals coat the lithoid tufa between 3,960 and 3,975 feet altitude. Thinolite is absent in offshore sand and clay of lower and dendritic members of the Sehoo $\left(Q_{s S_{1}}, Q_{s c}\right.$, and $\left.Q \mathrm{Ss}_{2}\right)$ at this locality. Resting on the upper sand are a few tufa "heads" of dendritic member, deposited during recession of the middle Sehoo lake.

and $41 / 2$ miles eastward from Timber Lake. Here the upperpart of the clay of the Sehoo has been deflated and the thinolite is a lag residue from the thinolite unit.

\section{DENDRITIC MEMBER}

The dendritic member of the Sehoo formation consists of lacustrine sediments that record the middle Sehoo lake cycle and extend to the high shore of this lake at an altitude of about 4,190 feet. It is commonly 1 to 8 feet, rarely as much as 25 feet, thick, and comprises nearly a quarter of the uneroded volume of the Sehoo. In the lowlands it is mainly clay, with silt, sand, and a little lacustrine limestone locally; in the highlands it is sand, gravel, and minor amounts of tufa, silt, and clay, and it is characterized by lateral changes from gravel to sand or even silt within a few feet. Dendritic tufa is the most distinctive and widespread of several varieties present (table 5), and hence the name of the member. The highest shoreline of the middle Sehoo lake, the dendritic terrace of Russell (1885, p. 101-102), is marked neither by distinctive deposits nor by prominent shore features and is only locally distinguishable. The type locality of this member is the site of section 32 (table 10), east of Rainbow Mountain, where the member consists of $31 / 2$ feet of gravel that makes up a bar which marks the dendritic terrace.

Gravel of the dendritic member is much scantier and generally finer than that of the lower member, and the associated shorelines are less prominent (pl. 9). The gravel resembles the regressive gravel of the lower member in lithology and thickness; cobble to fine pebble gravel, generally 1 to several feet, rarely 5 feet or more, thick. It is more prominent in mountain reentrants and intermountain saddles such as those east and west of Rainbow Mountain, where it occurs in widely separated terraces, bars, and spits. Transgressive and regressive phases can be distinguished locally by differences in lithology (table 4) and by separating deposits of dendritic tufa in place or, below about 4,100 feet, by separating clay, silt, and lacustrine limestone.

Sand of the dendritic member is distributed similarly to that of the lower member, but on highland shores it is somewhat more widespread, being present in many areas where the lower member is largely gravel. Few of the main shorelines of the middle Sehoo lake are at the same levels as those of the early Sehoo lake, so bars and spits of gravel of the lower member commonly are covered by sand of the dendritic member. This sand is widespread on the delta of the Carson River west of Fallon, where it locally attains 20 feet in thickness; away from this delta it rarely is more than 5 feet thick. Generally this sand resembles that of the lower member except that it lacks the yellowish cast; locally in thick deposits in valleys, however, it is pale yellow tan to pale orange brown and somewhat darker than the sand of the lower member.

Clay of the dendritic member typically is less silty, more limy, and more saline than that of the lower mem- 
ber. The clay is in places bentonitic, and also characteristically somewhat brighter greenish gray; locally some beds are green and bluish green. Lamination and bedding generally are more distinct than in the lower member, and in places the beds or laminae show appreciable color contrast. Commonly small disseminated calcium carbonate nodules and oolites continue from the thinolite unit a few feet upward into the dendritic member. Ostracods are common throughout, particularly in the upper part. Close to highland shores bearing thick dendritic tufa, the clay and silt are especially rich in calcium carbonate and commonly contain platy nodular bodies of limestone generally less than $1 / 2$ inch thick and 1 to 12 inches in diameter. This member has been completely eroded by deflation from large areas in the basin interior.

\section{UPPER MEMBER}

The upper member of the Sehoo formation is the deposits of the late Sehoo lake cycle. It extends up to the highest shoreline of the late Sehoo lake at an altitude of about 3,990 feet, but this shoreline is weakly marked and only locally distinguishable. This member generally is 1 to 5 feet and rarely as much as 16 feet thick. The type locality is an exposure of sand in the scarp of a deflation basin next to the former Fallon-Lovelock cutoff, 3.9 miles north of the south edge of the Soda Lake quadrangle, the site of section 8 (table 10).

Gravel of the upper member is restricted to small patches close to the mountains along the highest shorelines of the late Sehoo lake. The gravel is thinner, finer textured (fine-pebble gravel to pebbly sand), and poorer sorted than older gravels of the Sehoo (table 4), but it is more abundant and generally coarser than the lake gravels of the Fallon formation.

Sand is much more widespread than either gravel or clay in the upper member. Although thin compared with older shore sediments, it is considerably thicker and more extensive than any of the lake sands of the Fallon. It is widely exposed on two former deltas of the Carson River within the main basin and also in selvages at the edges of the lowlands. This sand is commonly severely eroded by deflation, particularly on the deltas. Deflation basins 10 to 40 feet or more deep have been scooped out in areas between the distributary channels, whereas the latter have tended to remain relatively uneroded, probably because the coarser sediment resisted deflation. Below 3,950 feet, the high shoreline of the first Fallon lake (table 7), this sand commonly is thinly veneered with lake sand of the Fallon.

One of the deltas on which this sand is widespread lies mostly in the southeastern part of the Soda Lake quadrangle, though small erosional remnants extend into the adjacent quadrangles; it is about 10 miles wide north to south. This delta, called the west delta, is graded to the highest shoreline of the late Sehoo lake. Its surface lies a few feet above the modern flood plain and heads at the mouth of the inner valley of the river at an altitude of about 4,020 feet, in sec. 30, T. 19 N., R. 28 E. The sand on this delta is commonly 5 to 10 feet and locally as much as 16 feet thick; it generally thickens and grades coarser westward; the uppermost deposits and those adjacent to distributary channels of the Indian Lakes formation are generally the coarsest. West of Rattlesnake Hill the sand is mostly very arkosic, pebbly, granule to medium, and includes some fine sand and silt and local stringers of fine gravel. Most beds are moderately indistinct to clear, and generally parallel, though locally inclined. The sand grains are generally subangular; the pebbles, subrounded. Fragments of gray to nearly black lithoid tufa (late lithoid tufa of this member, table 5) mostly less than half an inch across, commonly are abundant in the upper several feet of the sand. Near the base are local partings of basaltic sand, which may have come from eruptions at Soda Lakes (p. 72). Eastward from Rattlesnake Hill the sand grades rapidly finer and is interbedded with increasing amounts of silt. On the bare flat just southwest of the Sagouspe fault zone it typically consists of several feet of thinly interlaminated fine sand and silt.

The other delta of the upper member, called the Indian Lakes delta, is in the western part of the Indian Lakes area, east of the present course of the Carson River. This delta is smaller than the western oneabout $51 / 2$ miles long by $41 / 2$ miles wide-has an even lower gradient, somewhat finer sediment, and is somewhat younger. It has two conspicuous distributary channels of alluvial sand of the Indian Lakes formation. They trend toward the gap through the scarp of the Sagouspe fault zone and probably headed at the bottom of the trench that was cut by the Carson River through the scarp, at an altitude of about 3,927 feet. These distributary channels cannot actually be proved to head here, as the Fallon formation covers the parts of the channels immediately below the gap, but there is no suggestion that either the channels or the delta sand continue west of the scarp; hence this delta probably postdates the scarp and formed while the late Sehoo lake receded from an altitude of 3,927 to 3,917 feet. Furthermore, the stratigraphic relations of early lithoid tufa and sand of the upper member to faults in the western part of the fault zone (p. 93) show that the faulting followed deposition of the early lithoid tufa and preceded deposition of lake sand on the delta. Two small grabens in this fault zone in the NW1/4 sec. 3, T. 19 N., 
R. $29 \mathrm{E}$., contain as much as 10 feet of sand of this member (fig. 36).

Outside the river deltas, sand of the upper member is fairly widespread near the base of the hillshores, between altitudes of 4,000 and 3,915 feet. It is the only shore deposit of this member in most places, but definite bars or other shore features are rare; generally the sand is merely a gently sloping sheet several inches to a few feet thick and a few tens of feet to locally more than 1 mile wide. The main deposits are on the flat between Stillwater Slough and the Lahontan Mountains and along the border of the western Bunejug Mountains and Turupah and Eightmile Flats.

In the upper member of the Sehoo the change from sand to silt to clay takes place between altitudes of 3,940 and 3,925 feet except on the Indian Lakes delta, where sand extends down to about 3,910 feet. On the deltas the silty transitional zone commonly is 1 mile wide or more, 2 to 5 feet thick, and characterized by interfingering sand, silt, and clay; elsewhere it is generally less than half a mile wide and rarely more than 1 foot thick. Below 3,920 feet this member is mostly a thin layer of clay, only locally 1 foot or more thick (over large areas it has been completely deflated); the clay is thickest, locally as much as 4 feet, in the Stillwater Slough-Carson Lake and Indian Lakes areas. This clay unit commonly is disconformable upon clay of the dendritic member above an altitude of 3,920 feet, and locally as low as about 3,900 feet (p. 62). The two clays are separated locally by colluvium of the upper member of the Indian Lakes formation, the Harmon School soil, and early lithoid tufa of the upper member of the Sehoo.

Silt of the upper member generally is light to medium brown or brown-gray. Clay is medium- to dark-drab brown-gray, greenish gray, or olive-drab gray, somewhat darker than clay of the dendritic and lower.members, to locally nearly black, especially at the base; small calcium carbonate nodules occur locally. Sections 22a, 23,28 , and 35 illustrate this unit (table 10).

Two principal horizons of tufa are present in the upper member-one at the base of the member, and the other in its upper part. Each is distinctive (table 6) and hence a good stratigraphic marker.

\section{SHORE FEATURES OF SHHOO AGE}

The age relations of shore features of Sehoo age are best demonstrated by the stratigraphy of the Sehoo formation associated with them. Plate 9 shows the altitudes of the main shorelines formed by the three Sehoo lakes. The most prominent shorelines date from the transgression of the early Sehoo lake, less prominent ones from the regression of this lake and the transgression of the middle Sehoo lake, rather weak ones from the regression of the middle Sehoo lake, and very weak ones from the late Sehoo lake.

\section{SHOREIINES OF THE EARIY SEHOO IAKE}

Transgressive shorelines.-The most prominent shorelines of Sehoo age are overlain by transgressive-phase gravel of the lower member of the Sehoo, and hence date from the transgression of the early Sehoo lake. They are only slightly less strongly developed than those of Eetza age. They attain their fullest development on highland shores that front upon the main Carson Desert and that face north, northeast, northwest, west, or southwest. Here the main shorelines are markedly disconformable upon shore features of Eetza age and upon alluvial fans and dunes of the Wyemaha formation; they are marked not only by large constructional terraces, bars, and spits, but also by local, moderate terraces, cliffs, and caves cut in bedrock. On the other hand, shorelines of early Sehoo age are at best poorly developed on shores exposed only to the southeast and east, in contrast to shorelines of Eetza age.

Highest shoreline.-A strongly developed shoreline at an altitude of about 4,370 feet marks the highest level reached by the early Sehoo lake. This shoreline is only about 10 feet below the Lahontan beach (p. 30, 64, 65). Commonly the two shorelines are difficult to separate because they are almost superimposed, the Lahontan beach is poorly developed, and the gravels of the two shorelines are similar. Four criteria useful for differentiation are:

1. Eolian sand and alluvium of the Wyemaha formation locally separate the Eetza and Sehoo formations.

2. Beaches underlain by the Sehoo formation bear only the Toyeh soil (p. 78), whereas those above the highest early Sehoo shoreline and underlain by the Eetza formation bear the Churchill soil.

3. Shore features of Eetza age are slightly more eroded than those of Sehoo age below.

4. Embankments of gravel of the Eetza formation were wavecut at the highest shore of the early Sehoo lake, and the resulting scarps are fresher than the Eetza shore features above.

Regressive shorelines.-Shorelines associated with regressive-phase gravel of the lower member of the Sehoo, that is, dating from the regression of the early Sehoo lake, are less developed than those formed during the transgression. None have rock-cut features or associated boulder gravel. They are rare and very weak for at least 150 feet vertically below the 4,265 -foot shoreline (pl. 9); this zone shows as a broad band on the old lake shores where the blanket of cellular tufa, if present, is unbroken by later wave scarping and where 
overlying lake sand and gravel of the regressive phase of the lower member of the Sehoo is very local and thin. Below the highest shoreline of the middle Sehoo lake (about 4,190 feet), the regressive shorelines of the early Sehoo lake commonly are obscured by the reworking done by the later lake.

\section{COMPARATIVE HEIGHTS OF HIGHEST EETZA AND EARLY SEHOO} SHORELINES AT RUSSELI SPIT

This writer's conclusions on the comparative heights of the Eetza and early Sehoo lake maximums differ from those reached by Russell (1885), and also from those reached by Jones $(1925,1933)$ and, in part, by Antevs (1925a, 1945, 1948, 1952). Only Russell has published concrete field evidence, and only his interpretations will be considered here. Russell concluded that at the maximum of the first deep-lake period (Eetza time of this report), Lake Lahontan rose only to the lithoid terrace level (about 4,350 to 4,370 feet in the map area), and that at the maximum of the second deep-lake period (Sehoo time of this report), it rose to the Lahontan beach (about 4,380 feet). He deduced this history by interpreting the order of formation of overlapping high-shore spits, bars, and terraces, particularly at an unusually instructive compound spit on the west side of the pass between the White Throne and Desert Mountains, now known as Russell Spit (Russell, 1885, p. 113114 and pl. 19; also see U.S. Geological Survey map of Weber Reservoir 15-minute quadrangle).

Russell reasoned that at Russell Spit the overlapping relations of the different lake-gravel embankments indicate that the highest ones are the youngest, and particularly, that embankment $A$ was built over and hence is younger than embankment $C$ (fig. 28). He believed that lithoid tufa was deposited only during the first deep-lake period, and concluded that embankment $C$ postdates the one just below it because this tufa encrusts the gravel on the lower embankment. In his summary, he $(1885$, p. 170-171) noted, however, that the geomorphic evidence from this and other localities was inconclusive, and that the "chemical evidence" afforded by the sequence of deposition of the tufas was more significant.

The writer's observations and deductions on the stratigraphic and geomorphic relations at Russell Spit are as follows (fig. 29):

1. The uppermost spits ( $A$ and $B$, fig. 28 ) are made up solely of gravel of the Eetza formation and hence were not built during the second deep-lake period (Sehoo time) as Russell believed. This gravel bears typical Churchill soil and neither the gravel nor the soil has been reworked by later lake action. At spit $A$ the Lahontan beach is at an altitude of 4,378 feet, as deter- mined by a line of level run by G. M. Stanley in 1948 from the Nevada Highway Department bench mark at Russell Pass.

2. The crest line of spit $C$ is irregular; it is 2 to 3 feet higher in the central part than at either the distal (south) or the shoreward (northwest) end. This condition is anomalous, as the crest line of a monogenetic spit normally becomes lower, not higher, offshore; it suggests that the higher part may be a remnant of an older spit. The detailed mapping bears out this suggestion. The gravel of the higher central part bears soil correlated with the Churchill soil, whereas the gravel at the ends bears soil correlated with the Toyeh soil. The higher gravel also is more heavily coated with desert varnish than the lower. Geomorphic relations indicate that both gaps were cut by subaerial, not lacustrine, erosion. Erosion of the north gap was shallow, for test pits show that the Sehoo formation here is commonly only 1 or 2 feet thick, and is over Eetza formation which bears eroded Churchill soil.

Additional evidence that the spit became breached between the two lake occupations is given by the directions of longshore transport that can be inferred from the composition of the two gravels. The Eetza formation is cobble gravel containing rhyolite, andesite, and basalt. The rhyolite could have come only from outcrops to the northwest, and some of the andesite could have come only from the southeast. Yet the top (Eetza) level of the spit now ends 300 feet short of the south shore, and is separated from this shore by the 10-foot-deep gap at the south end of the spit. The Sehoo formation, on the other hand, is medium gravel consisting of rhyolite and a little andesite like that in dikes just northwest of the spit; the composition and morphology of this part of the spit indicate derivation solely from the northwest.

3. The tufa that encrusts the gravel on the first terrace below spit $C$ (at about 4,355 feet) is of two ages: The earlier-lithoid tufa of the Eetza formation-is exposed locally in the wave-cut scarp below the front edge of this terrace; locally veneering this cut surface and overlapping gravel of the lower member of the Sehoo formation is cellular tufa, also of the lower member of the Sehoo, that extends to about the same altitude as the earlier tufa. Geomorphic superposition shows that part of spit $C$ (the part built in early Sehoo time) postdates the cellular tufa deposition, but it does not prove that the whole of this spit was built during a separate later lake cycle, as Russell inferred.

The inferred lake history at Russell Spit is as follows:

1. Eetza time: During the transgression of the first Eetza lake a gravel spit was constructed at this site at 
an altitude of about 4,355 feet. The gravel was partly cemented by the highest deposits of lithoid tufa of Eetza age. Soon after, when the lake had risen about 15 feet higher, spit $C$ was built all the way across the embayment by long-shore drift from both the northwest and the southeast. When this lake cycle reached its maximum (the maximum for all Lake Lahontan time) at 4,378 feet, spit $A$ was built. During recession of this lake, minor further deposition and modification of spit $C$ and lower shore features may have occurred. The maximum of the second Eetza lake was well below these spits.

2. Wyemaha and Churchill time: Subaerial erosion of these shore features during Wyemaha time is not evident. In Churchill time, the Churchill soil formed on them.

3. Sehoo time: Spit $C$ was subaerially eroded in very early Sehoo time, after the Churchill soil formed and before the early Sehoo lake had risen to the level of the spit. Probably the large wash that heads back of the reentrant overflowed the spit, corrading several feet at the northwest end, and more at the south end of the spit. As the lake rose the earlier embankment was scarped at 4,340-4,350 feet, and a coating of cellular tufa was deposited to a maximum altitude of 4,355 feet. The early Sehoo lake reached its maximum at 4,368 feet3 feet below the Eetza level of spit $C$ and 10 feet below the maximum lake level in Eetza time. At this level, gravel derived by longshore drift from the northwest healed the breach at the northwest end of the spit, and partly healed the breach at the south end by developing a series of small stepped spits; a shore terrace was cut into the side of $\operatorname{spit} A$. As the early Sehoo lake receded, it reworked earlier gravel to build most of the embankments seen today below spit $C$. This ended the lake history at this locality, for later lakes did not rise nearly this high.

\section{LARE LEVELS DURING DEPOSITION OF THE THINOLTTE UNIT}

The 4,040-foot shoreline is the lowest definite shoreline formed during the regression of the early Sehoo lake. Lake Lahontan fell at least 50 feet below this level during deposition of the thinolite member (pl. 10), but this minimum lake level is not marked by a shoreline or shore gravel of the same age as the thinolite unit. Strongly developed terraces at altitudes of 3,990-4,010 feet in the Carson Desert, which are possibly correlative with the thinolite terrace at this altitude in the PyramidWinnemucca lake area (Russell, 1885, p. 237; Jones, J. C., 1925 , p. 43 ; Antevs, 1945 , p. 30 ), date mainly from Eetza time (p. 31)-long before the main thinolite deposition in the Carson Desert.
SHORELINES OF THE MIDDLE SEHOO LAKE; "DENTRITIC TERRACE"

Of the four distinct shorelines (pl. 9) associated with transgressive-phase gravel of the dendritic member of the Sehoo, only the 4,045-foot shoreline is well marked.

A weak shoreline at about 4,190 feet seems to mark the highest level reached by the middle Sehoo lake. This shoreline is the upper limit of dendritic tufa deposition, and probably is the same as Russell's dendritic terrace (Russell, 1885, p. 101-102; Antevs, 1945, p. 30). It is marked neither by distinctive deposits nor by prominent morphologic features and is only locally distinguishable. In places, for example, the dendritic tufa resembles "coralline" tufa, and the gravel resembles regressive gravel, of the lower member of the Sehoo. The high shoreline is locally clearly marked by gravel bars in intermountain saddles such as those east and west of Rainbow Mountain and between the White Throne and Desert Mountains, but it is obscure on the mountainous shores except for tiny bars of gravel of the dendritic member in a few places.

About 14 moderately to strongly marked shorelines are associated with the regressive-phase gravel of this member. They are conspicuous because they are the youngest shorelines on the highland shores and have not been modified by later lake erosion. The terraces, bars, and spits of all the middle Sehoo shorelines, both the transgressive and regressive, consist of fine to medium pebble gravel; rock-cut features are absent.

\section{SHORELINES OF THE LATE SEHOO LAKE}

Shorelines of late Sehoo age are weakly developed and few-there are two high shorelines, 10 feet apart, and a regressive one. The high pair is marked locally by small bars and terraces consisting generally of pebbly sand and sand but of fine gravel in a few places close to mountains. The highest shoreline generally is at an altitude of $3,990 \pm 10$ feet (for example, the western Lahontan and northern Bunejug Mountains, southeastern Bass Flat, and northern piedmont of Desert Mountains; pl. 2). At the northeast edge of the Lahontan Mountains, east and northeast of Reed Butte, and in the saddle between Rainbow Mountain and the Stillwater Range, however, the shoreline is lower3,980 to 3,975 feet-due probably to local downwarping. On the west river delta and east of the Dead Camel Mountains it has been almost completely deflated or covered by eolian sand.

The delta at Indian Lakes (p. 62,63) marks a regressive shoreline at an altitude of $3,917-3,927$ feet. The small size and simple structure of this delta suggest that it formed during a comparatively brief stillstand. 


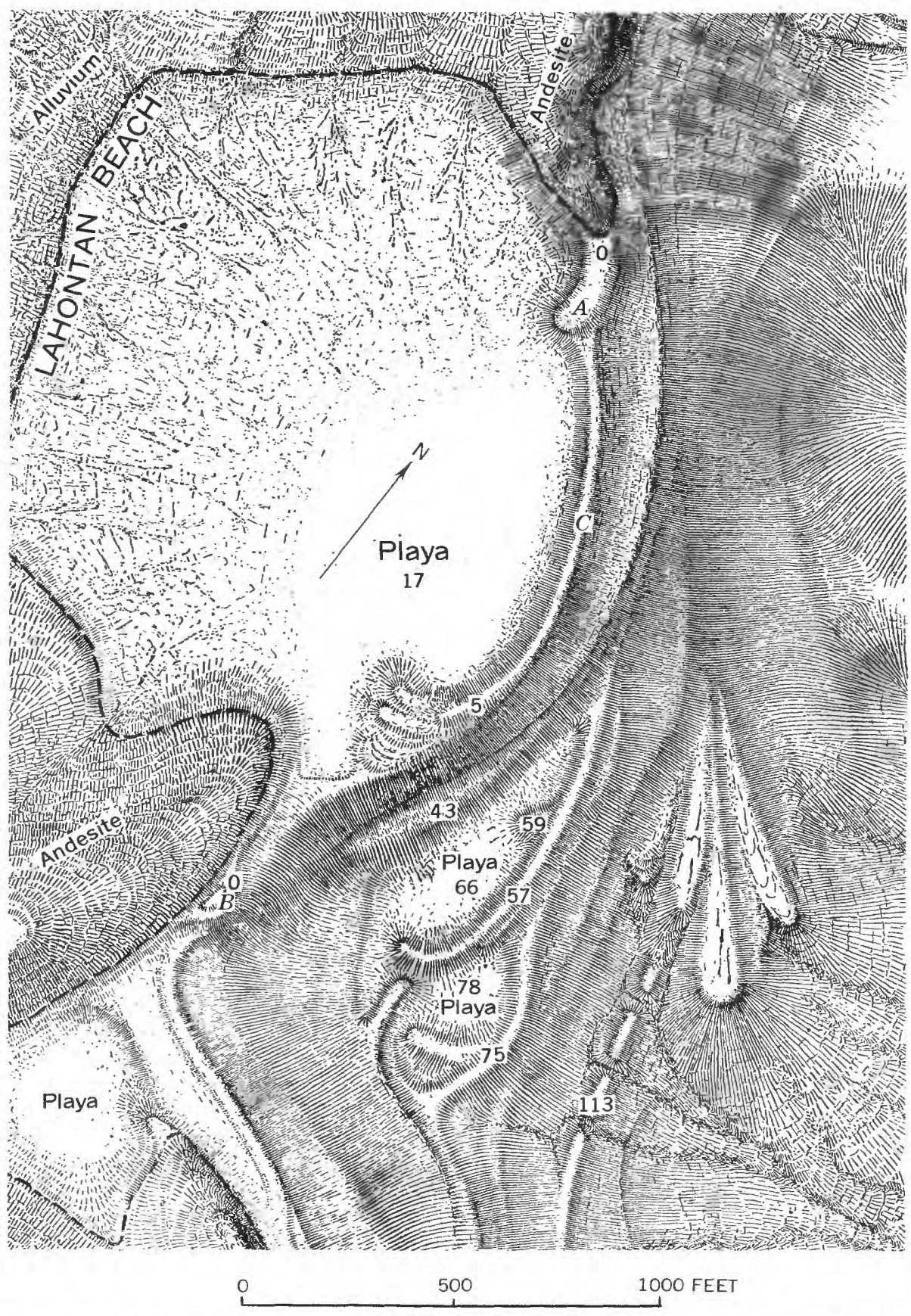

FIGURE 28.-Hachure map of Russell spit and vicinity. Part of plate XIX in Russell's (1885) monograph on Lake Lahontan. Mapped by W. D. Johnson; numerals are Johnson's elevations below zero datum, which is at the highest shoreline of Lake Lahontan (Lahontan beach) on spit $A$. 


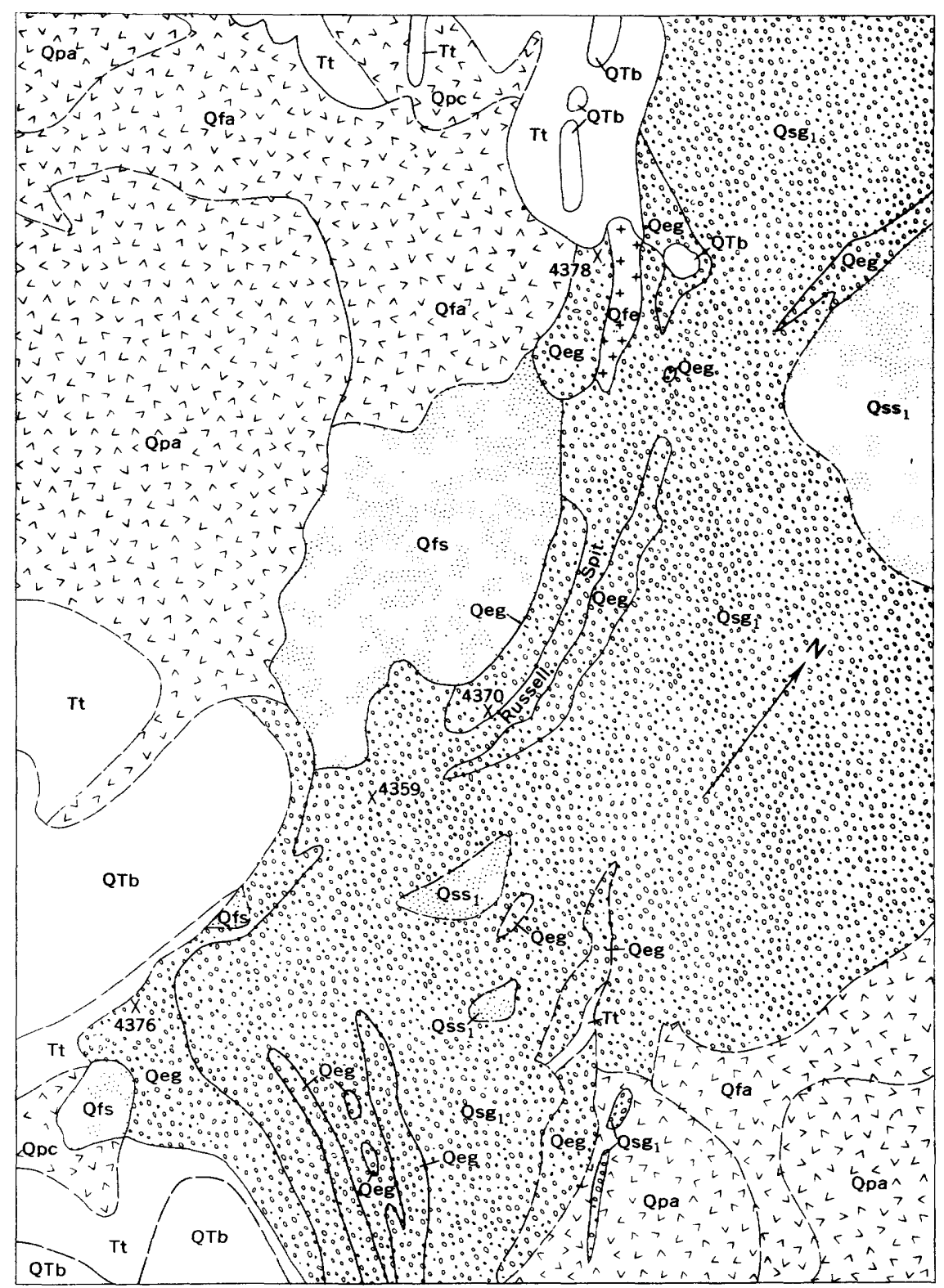

500

1000 FEET

\section{EXPLANATION}
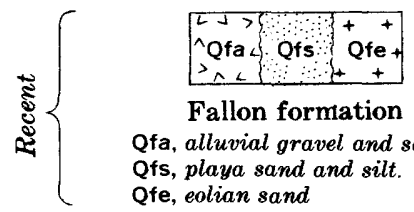

Fallon formation

Qfa, alluvial gravel and sand.

Qfs, playa sand and silt.

Qfe, eolian sand

(Time of Toyeh soil formation)

UNCONFORMITY

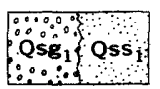

Sehoo formation

$\mathrm{Qsg}_{1}$, lake gravel of the lower member boulder gravel to pebble gravel, locally some sand.

Qss $_{1}$, lake sand of the lower member

(Time of Churchill soil formation)

UNCONFORMITY

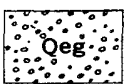

Eetza formation

Lake gravel. Boulder gravel to pebble gravel

(Time of Cocoon soil formation)

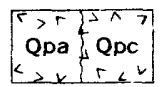

Paiute formation

Qpa, alluvial gravel.

Qpc, colluvium (creep mantle and talus)

UNCONFORMITY

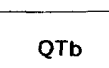

Bunejug formation

Basalt and andesite flows and dikes

UNCONFORMITY

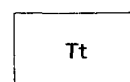

Truckee formation

Diatomite, silicic tuff, and tuffaceous shale and sandstone

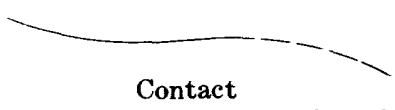

Dashed where approximately located

$x^{4359}$

Altitude, in feet above sea level Determined by G. M. Stanley, 1948, by line of level from Nevada Highway

Dept. bench mark at Russell Pass 
LAKE LAHONTAN: GEOLOGY, CARSON DESERT, NEV.

\section{INDIAN LAKES FORMATION}

GENERAL FEATURES

The Indian Lakes formation (Morrison, 1961a) consists of alluvium, some colluvium, eolian sand, very shallow lake silt and clay, and locally volcanic sand of the same age as the Sehoo formation and intertonguing with it. It overlies the Wyemaha formation, with slight or no disconformity, is younger than the Churchill soil, and is overlain by the Turupah formation. The Indian Lakes formation is sparsely distributed in both highlands and lowlands, and is commonly only several inches to several feet thick, having a maximum thickness of perhaps 15 feet in alluvial channels.

At its type locality, the western part of the Indian Lakes area, SE $1 / 4$, T. 20 N., R. 29 E. and SW $1 / 4$ T. 20 N., R. 30 E., alluvial sand of this formation makes up two prominent distributary channels on a delta of late Sehoo age.

\section{TONGUES AND AGE UNITS}

The Indian Lakes formation always is subdivided on the geologic maps (unlike the Sehoo formation) and in the stratigraphic sections. It is subdivided into tongues where it is actually intercalated with members of the Sehoo formation or the Sehoo and the Churchill soil; in other places it is subdivided into age units as a result of correlation with the Sehoo formation.

Three tongues-lower, middle, and upper-are differentiated in stratigraphic sections, but only the middle tongue in the Carson Lake quadrangle is used as a map unit as the others are too thin. The lower tongue, of early Sehoo and Indian Lakes age, is between the Churchill soil and the lower member of the Sehoo formation; the middle tongue, of early and middle Sehoo and Indian Lakes age, is between the lower and dendritic members of the Sehoo; the upper tongue, of middle and late Sehoo and Indian Lakes age, is between the dendritic and upper members of the Sehoo. The time intervals of the middle and upper tongues are locally represented, at least in part, by very weakly developed soils and by disconformities within the Sehoo formation that record subaerial exposure. These two tongues and the coeval disconformities and soils attest to recession of Lake Lahontan to altitudes of at least as low as 3,990 (middle tongue) and 3,900 (upper tongue) feet. The recession during the time represented by the middle tongue is here called the thinolite recession (after the thinolite unit of the Sehoo formation); and the recession during the time of the upper tongue is called the late Sehoo recession.

Alluvium of middle Sehoo and Indian Lakes age, mapped only in the Fallon and Soda Lakes quadrangles, overlies the dendritic member of the Sehoo formation at altitudes above the highest shore of the late Sehoo Lake (and hence above the upper tongue of the Indian Lakes formation). Alluvium of late Sehoo and Indian Lakes age, mapped in all four quadrangles, ranges from far above the high shore of the late Sehoo Lake to 80 feet below this shore, and it both intertongues with and overlies the upper member of the Sehoo formation. A volcanic-sand complex of early (?), middle, and late Sehoo and Indian Lakes age is mapped as part of the Indian Lakes formation in the Soda Lake area.

\section{ALLUVIUM AND COLLUVIUM ABONE THE LAHONTAN BEACH}

Alluvium and colluvium of this formation are exposed in the mountains above the Lahontan beach in tiny patches a few inches to several feet thick-hence unmappable - and cannot be differentiated as to member or age subdivisions within the formation. The alluvium is bouldery gravel that mantles local terraces a few feet above present wash beds. The colluvium is mostly block streams on steep slopes (probably developed by washing out of fines from solifluction mantle of Eetza age) and slope wash near the base of slopes and in swales.

\section{LOWER TONGUE}

The lower tongue consists of alluvial sand and gravel between the Wyemaha formation and the lower member of the Sehoo formation; it is younger than the Churchill soil. It is differentiated only below an altitude of 4,370 feet, the highest altitude reached by the lower Sehoo. Occurrences are rare and too thin to be mapped. The type locality is the site of section 34 (table 10) in Churchill Valley, where this member is alluvial sand between the Churchill soil and the lower member of the Sehoo.

\section{MIDDLE TONGUE}

The middle tongue consists of alluvial gravel, colluvium, and eolian sand. It is differentiated only below the high shore of the middle Sehoo Lake, at an altitude of about 4,190 feet, and occurs locally down to about 3,990 feet. It represents not only time represented by the thinolite unit of the Sehoo (here called thinolite recession time), but also parts of early Sehoo Lake time and middle Sehoo Lake time ( $\mathrm{pl.12}$ ). The type locality is the site of section 39 (table 10), in Hidden Cave, in Eetza Mountain. The member is bed 10 in this section, which consists of colluvium (slope wash) 1.7 feet thick between clay and silt of the lower and dendritic members of the Sehoo formation, at an altitude of about 4,095 feet.

The middle tongue has been recognized and differentiated chiefly in the Carson Lake quadrangle. It is 
here principally alluvial gravel, which forms tiny alluvial fans 1 foot to perhaps 5 feet thick on piedmont slopes, over gravel of the lower member of the Sehoo. The alluvial gravel is locally overlain by 1 foot to several feet of dendritic tufa and(or) gravel of the dendritic member of the Sehoo. The middle Sehoo lake eroded these fans relatively little and the pattern of their distributary channels still is evident. The chief occurrences and approximate lowest altitudes reached by the alluvium are: (a) secs. 10 and 14, T. 18 N., R. 30 E., on the north side of Sehoo Mountain, 4,020 feet; (b) SW1/4 sec. 28 and NW1/4 sec. 33 , T. 17 N., R. 30 E., southwestern piedmont of the Bunejug Mountains, 4,0.70 feet; (c) SW1/4 sec. 33, T. 17 N., R. 30 E., 4,040 feet; (d) sec. 26 (unsurveyed), T. 17 N., R. 30 E., east side of the Bunejug Mountains, 4,120 feet; (e) N1/2 sec. 16 (unsurveyed), T. 16 N., R. 31 E., east side of the Cocoon Mountains, 4,020 feet; (f) NE1/4NW1/4 sec. 9, T. 16 N., R. 29 E., north side of the White Throne Mountains, 4,015 feet; (g) NW1/4 SW1/4 sec. 3, T. 16 N., R. 29 E., north side of the White Throne Mountains, 4,010 feet.

Colluvium (slope wash) of this tongue can be seen at Hidden Cave, the type locality, and locally in some of the gravel pits in western Wyemaha Valley (fig. $15 C$ ).

Disconformity coeval with the middle tongue.-The lower and dendritic members of the Sehoo formation are separated locally between altitudes of about 4,190 and 3,990 feet by an incipient soil (p. 75) and (or) by a disconformity that records subaerial exposure during the time interval of the middle tongue of the Indian Lakes formation. In most places, however, these subaerial features were obliterated by wave erosion of the middle Sehoo lake. The disconformity has been noted as low as about 3,990 feet at the extreme west edge of Wyemaha Valley (pl. 8 and sections 41 and 42, table 10 ), where it locally is underlain by an incipient soil. In places it is indicated by gullies cut into gravel of the lower member and filled by gravel of the dendritic member of the Sehoo formation; the lowest such occurrence in the Carson Lake quadrangle is at an altitude of about 4,020 feet in the long spit extending southward from the southwestern Bunejug Mountains (fig. 25). A filled valley on the Carson River delta probably also indicates this disconformity. The road from U.S. Highway 50 to Northam School, on the line between secs. 19 and 20, T. 19 N., R. 27 E., crosses a deep channel cut into clayey sediments of the lower member of the Sehoo and filled by silt and sand probably of the dendritic member of the Sehoo. The channel probably was cut during the thinolite lake recession. The fill extends below an altitude of 4,040 feet so Lake Lahontan fell still lower during this recession.
ALLUVIUM OF MIDDLE SEHOO AND INDIAN LAKES AGE

Alluvium of middle Sehoo and Indian Lakes age is on the Carson River delta in the Soda Lake quadrangle, where it consists of sandy gravel and sand in an old distributary channel that extends from sec. 14, T. 19 N., R. 27 E., to sec. 25, T. 20 N., R. 27 E. The distributary channel overlies the dendritic member of the Sehoo (hence is younger than the middle tongue of the Indian Lakes formation) and seems to have formed when the middle Sehoo lake stood at an altitude of about 4,010 feet during its recession.

Upper tongue.-The upper tongue consists of local colluvium and marsh silt or very shallow lake silt and clay intercalated between the dendritic and upper members of the Sehoo formation. It can be distinguished only where it is overlain by the upper member of the Sehoo, that is, below 3,900 \pm 10 feet; it is everywhere too thin to be mapped, but is differentiated in stratigraphic sections.

The type locality is the site of section 17 (table 10), about two-thirds of a mile north of Harmon School (not in use), where an irrigation canal exposes a 3-foot bed of colluvium of this member that locally bears the Harmon School soil (p. 75) and is intercalated between clay of the dendritic member and silt and sand of the upper member of the Sehoo.

Colluvium similar to that at the type locality occurs discontinuously for several miles west of the Sagouspe fault zone, above that 3,925 feet altitude, and is as much as 3 feet thick. It consists of angular to subangular fragments of clay from the Sehoo formation, locally mixed with sand, which is indistinctly bedded and shows little evidence of transport; in places it bears the Harmon School soil. Commonly the lower contact of the colluvium is sharp but undulating, and the underlying lake clay is broken and closely jointed for about 1 foot below the contact.

Below 3,925 feet the member is rare, but it has been identified at 3,908 feet in a borehole along the Diagonal Drain in the SW $1 / 4$ sec. 17 , T. 18 N., R. 30 E., where it consists of $1 \frac{1}{2}$ feet of carbonaceous silt and sand between clay of the upper and dendritic members of the Sehoo; it also has been found at about 3,900 feet in the western Indian Lakes area, where it consists of $1 / 2$ to 2 feet of black carbonaceous silty clay, which is probably a marsh or swamp deposit (section 5, table 10).

Disconformity coeval with the upper tongue.-A disconformity within the Sehoo formation that records subaerial erosion commonly occurs at the same stratigraphic position and altitude range as the upper tongue of the Indian Lakes formation, where that 
tongue is missing. It is commonly marked by desiccation cracks and sand dikes in the underlying clay of the Sehoo formation, and in places it is underlain (fig. $30 A$ ) by the Harmon School soil (p.75).

This disconformity is widely exposed in deflation basins on the west delta of the late Sehoo lake, eastward to the Sagouspe fault zone. Here it commonly has a relief of several feet. It is readily confused with the larger unconformity of Turupah age (p. 75, 77), because eolian sand of the Turupah formation commonly
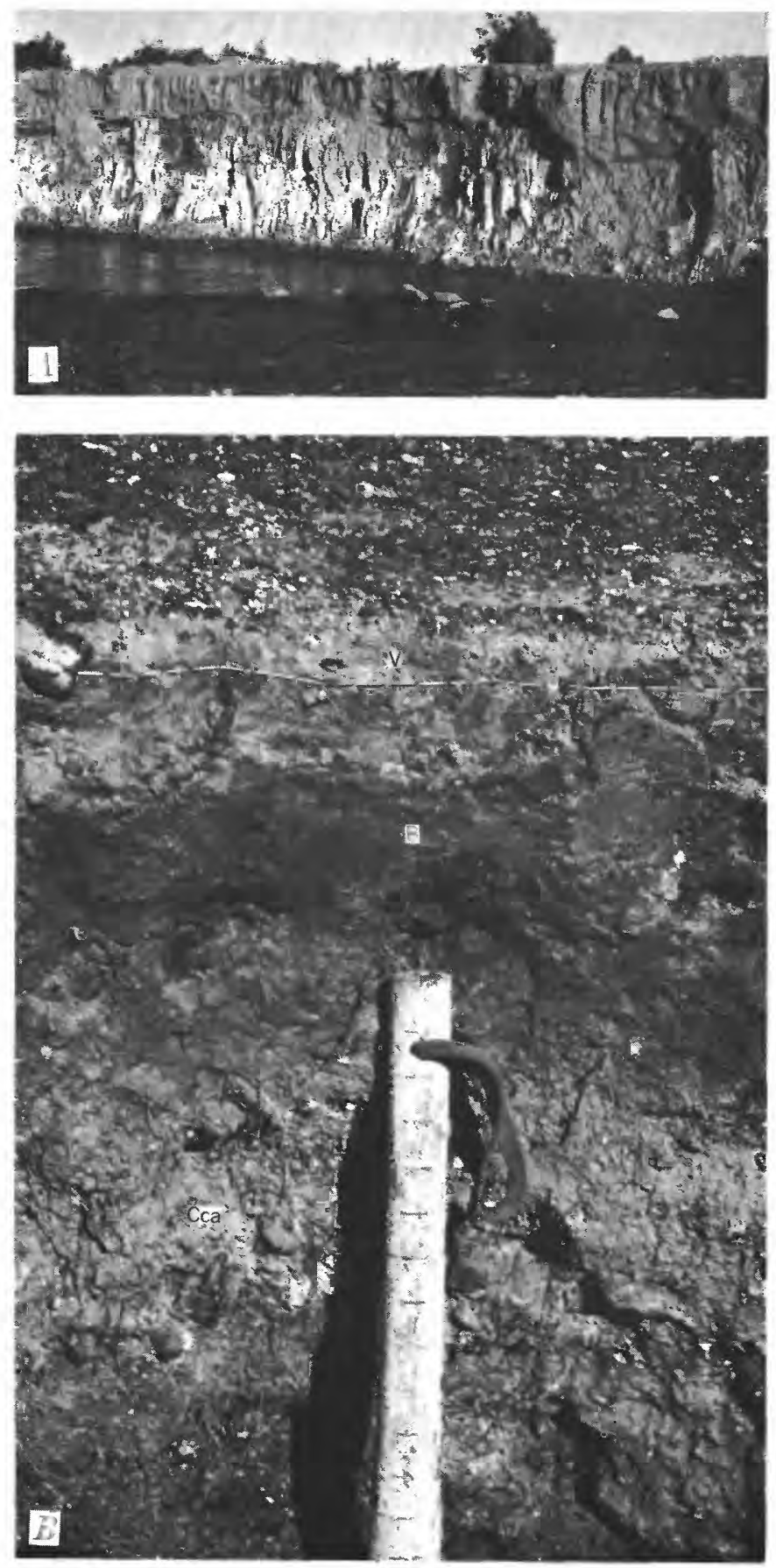

resembles sand of the upper member of the Sehoo on this delta; it can be distinguished with certainty where it is overlain by definite lake sediment, particularly early lithoid tufa of the upper member of the Sehoo.

Below about 3,910 feet this disconformity has not been identified with certainty, but additional evidence
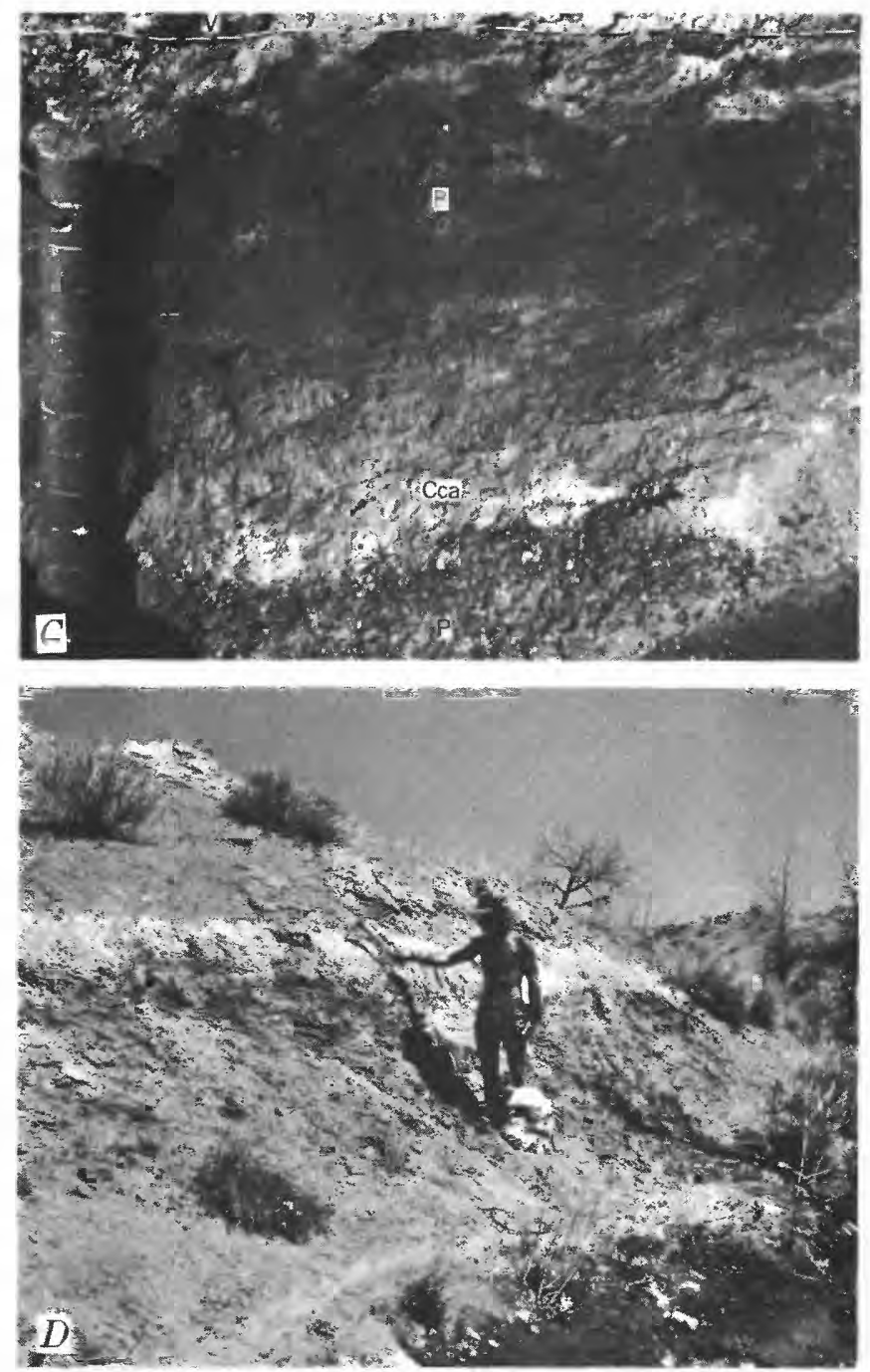

Figraw 30-A Sand of upper member of Sehoo formation disconformably overlying clay of the Sehoo. The disconformity represents upper tongue of Indian Lakes formation, and the weak Harmon School soil is locally preserved beneath it. Bank of outlet canal of S-Line Reservoir, sec. 27 , T. 19 N., R. 29 E. B, Relict occurrence of Toyeh soil in gravelly sand on a high-shore bar of the middle Sehoo lake (SW $1 / 4$ sec. 17 (unsurveyed), T. 18 N., R. 31 E.) and is typical of Toyeh soil above the high shore of the late Sehoo lake. $C$, Relict occurrence on a high-shore bar of the late Sehoo lake (SW1/4 sec. 4 (unsurveyed), T. 18 N., R. 31 E. V, vesicular horizon; $B$, oxide (B) horizon: Cca, calcareous ( $\mathrm{Cca}$ ) horizon (boundary) between oxide and calcareous horizons is gradational), $P$, parent material. $D$, Buried Toyeh soil. The soil formed on eolian sand of Turupah formation and is buried beneath sand of the first Fallon lake. Its calcareous horizon shows as the light-colored band at the top of the lower sand (where the man is holding the pick). The light color is due to concentration of calcium carbonate and other salts at the surface on weathering and is not nearly so pronounced in fresh exposures. Sagouspe irrigation canal, NW $1 / 4$ sec. 3, T. 19 N., R. 29 E. 
of the lower limit of the late Sehoo recession is the lowest altitude reached by early lithoid tufa of the upper member of the Sehoo (table 5), which probably formed in less than 5 feet of water. This tufa reaches altitudes as low as 3,885 feet as a local lag deposit on eroded clay of the lower and middle members of the Sehoo in the eastern part of the Stillwater quadrangle. Its original lowest altitude was $3,890-3,895$ feet when allowance is made for subsequent erosion and deformation, so probably Lake Lahontan fell at least as low as 3,900 feet during this recession.

ALLUVIUM, COLLUVIUM, AND EOLIAN SAND OF LATE SEHoO AND INDIAN LAKES AGE

Most of the Indian Lakes formation occurs at altitudes above the high shore of the late Sehoo lake, commonly resting on the dendritic member of the Sehoo. These deposits-mainly alluvium, and minor amounts of colluvium and eolian sand-are considered to be of late Sehoo and Indian Lakes age, and are not included in the upper tongue of the Indian Lakes, because, where they extend to or below the late Sehoo high shore, they intertongue with or rest on the upper member of the Sehoo, and hence are younger than the upper tongue of the Indian Lakes formation.

The alluvium of late Sehoo and Indian Lakes age was deposited by the Carson River and the highland washes. The wash alluvium is torrentially bedded and poorly sorted, having a wide range in size grade and a high percentage of angular and subangular fragments. It ranges from gravel and boulders locally several feet in diameter in the mountains, to sandy gravel and pebbly sand in distal parts of the fans. Where it can be differentiated from alluvium of the Fallon formation, it is generally more widespread and somewhat coarser.

The alluvium of the Carson River occurs in distributary channels on the two deltas of late Sehoo age ( $p$. $62,63)$ and on terrace remnants along the river upstream from the west delta. It is typical of relatively lowgradient perennial-stream deposition-pebbly to fine sand, fairly well sorted, and generally evenly bedded. Even in the coarsest deposits few pebbles exceed 1 inch in diameter.

The alluvial sand on the Indian Lakes delta marks two distributary channels that now appear as conspicuous ridges rising several feet above the delta; their coarser sediment has resisted subsequent deflation more than the interchannel sediments. The west channel can be traced for more than 3 miles; normally about 400 feet wide, it widens to 2,000 feet at its lower end, at an altitude of about 3,913 feet, where it intertongues with the upper member of the Sehoo. The east channel, roughly parallel to the west, can be traced for about
$61 / 2$ miles downstream to about 3,903 feet, 1 mile east of the terminus of the west channel. The highest exposures of both channels are only about half a mile apart, and there the channels are converging toward the gap cut by the river through the Sagouspe scarp. These channels are presumably distributaries from the same channel of the Carson River. The alluvium of both channels is fine-pebbly coarse and medium sand and scattered fragments of early lithoid tufa of the upper member of the Sehoo; it bears the Toyeh soil, which demonstrates its pre-Fallon age.

Colluvium considered to be of late Sehoo and Indian Lakes age occurs in Hidden Cave (bed 7, in section 39, table 10). It is a lenticular bed of coarse gravelly slope wash as much as 1 foot thick, which extends only a few feet into the cave. It overlies lake sand and gravel of the dendritic member of the Sehoo and is overlain by loess that is correlated with the Turupah formation.

Eolian sand of late Sehoo and Indian Lakes age locally intertongues with the upper member of the Sehoo on the west delta of the late Sehoo lake (section 7 , table 10).

\section{VOLCANIC-SAND COMPLEX OF SODA LAKE}

Soda and Little Soda Lakes occupy craters in an elliptical cone, 100 feet high and $11 / 3$ to $21 / 3$ miles in diameter, of sandy pyroclastic debris; the bottom of Soda Lake is about 230 feet below the general surface of the desert outside the cone. The cone deposits, mapped as the volcanic-sand complex of Soda Lake, are mainly sand, silt, and a little gravel, derived from underlying Quaternary sediments, and a small percentage of basaltic lapilli and bombs; no flows or dikes are present. The only good exposures are in the crater walls, especially the bluffs bordering the northeast half of Soda Lake. Three main stratigraphic units, separated by angular unconformities, were formerly exposed here (Russell, 1885 , p. $73-76, \mathrm{pl} .17$ ), but the 60 -foot rise in lake level since development of the Newlands Irrigation Project has left exposed only the upper unit and a local selvage of the middle unit.

The lower unit, according to Russell, is thinly bedded, perhaps lacustrine, sand and silt that contains abundant basaltic lapilli; the unit is cemented, jointed, and much faulted. Its former maximum exposed thickness apparently was between 10 and 20 feet; an angular unconformity having several feet of local erosional relief separates it from the middle unit.

The middle unit, according to Russell, is about 50 feet thick and consists of well-bedded moderately indurated basaltic lapilli sand, interbedded with considerable marl, silt, and clay that contain the pelecypod Anodonta, and locally, a few feet below the top, a layer of 
tufa; probably it is lacustrine throughout. This unit is locally faulted and an angular unconformity having several feet of local relief separates it from the upper unit. The only exposures of this unit still above water are a discontinuous selvage, half a foot to 15 feet thick along the southeast shore of Soda Lake (section 10, table 10) ; here the unit lacks both tufa and shells. It is tentatively correlated with the lower member of the Sehoo because the next overlying beds are correlated with the dendritic member of the Sehoo and the separating unconformity seems to represent a small time span.

The upper unit, as much as 120 feet thick, makes up nearly all the exposed volcanic sand of Soda Lake. It contains 4 zones, but the lowermost 2 zones are exposed only locally in the bluffs on the southeast side of the lake (section 10, table 10). The lowermost zone rests on the middle unit with a marked angular unconformity, and consists of $1 / 2$ to 2 feet of soft lacustrine silt overlain by about 7 feet of lacustrine well-sorted fine-pebbly sand and grit composed mainly of basaltic lapilli and a few waterworn fragments of dendritic and lithoid tufa, which are typical of the denditric member of the Sehoo; hence, this zone is correlated with the denditric member. The second zone, as much as 10 feet thick but locally absent, is poorly sorted indistinctly bedded fine-pebbly medium sand; it seems to be slope wash. The third zone, about 45 to 60 feet thick and probably lacustrine throughout, consists of a few feet of silt at the base, overlain by interbedded generally rather poorly sorted sand, fine-pebbly sand, and some fine gravel; it is moderately to well bedded, locally ripple bedded, and somewhat indurated. These beds contain several percent to locally more than 60 percent basaltic lapilli, and less than 1 percent to several percent coarser fragments (volcanic bombs and blocks) of basalt. These larger fragments are mostly less than half an inch in diameter, although cobble- and even boulder-sized fragments (to about 2 feet in diameter) occur rarely throughout the zone, as do some fragments of indurated silt and clay, waterworn fragments of dendritic and lithoid tufa, and, very rarely, pebbles of gneiss, rhyolite, and other nonbasaltic rocks. As Russell pointed out, the lapilli are angular, not water rounded, and the bombs have dense exteriors, scoriaceous interiors, and in places the beds for sevaral inches beneath the larger bombs are depressed. This zone also is correlated with the dendritic member of the Sehoo.

The fourth zone, about 40 feet thick, is similar to the third zone except it is practically unconsolidated, generally poorly sorted, and probably subaerially deposited. This zone is poorly exposed but underlies all the outer slopes of the cone. It locally is overlain by eolian sand of the Turupah formation, and it bears the
Toyeh soil where the eolian sand is absent. It is correlated with the upper member of the Sehoo.

At the periphery of the cone, relations of the volcanic sand to the Sehoo formation are poorly exposed, but $\operatorname{logs}$ of many wells in secs. 5 to 9 and 18, T. 19 N., R. 28 E. (W. O. Clark and C. H. Lee, written communication, 1916; Morrison, 1958a) suggest that at least the upper and middle units intertongue with and into the Sehoo. The boundary mapped is gradational; the Sehoo formation is sandier than normal for 1 mile or more beyond the boundary. On the west side of Soda Lake the tuff cone appears downfaulted; its boundary with the Sehoo is concealed by eolian sand and lies in front of a ridge that extends southwestward from the tuff cone. This ridge consists of relatively nonbasaltic Sehoo formation-about 35 feet of fine sand and some interbedded silt, capped by 10 feet of sand containing much dendritic tufa both as heads in place and as waterworn fragments. At least the upper part of the ridge sediments is correlated with the dendritic member of the Sehoo. The sediments cannot be correlated directly with those exposed in the tuff cone because eolian sand and slope wash conceal the transitional beds; they probably intergrade with the first and third zones of the upper unit in the tuff cone.

The eruptions recorded by the lower unit in the tuff cone are of uncertain, possibly early Sehoo, Wyemaha, or even Eetza, age. The middle unit may record eruptions beneath the early Sehoo Lake, but definite evidence is lacking in the trivial exposures now available. A conspicuous sand zone, interbedded between clay of the Sehoo and locally more than 5 feet thick, that extends 3 to 4 miles southeastward from the base of the Soda Lake cone, seems to be in the lower member of the Sehoo and may represent sand blown out by eruptions coeval with the middle unit.

The first three zones of the upper unit probably are of the same age as the dendritic member of the Sehoo; the first and third probably were derived mostly from material blown out by contemporaneous small underwater eruptions, though some parts may be merely reworked by lake waters and not directly derived from volcanism. The second zone probably records subaerial nonvolcanic deposition during a temporary minor recession of the middle Sehoo lake.

The fourth zone of the upper unit records the youngest eruption, which probably took place during the transgression of the late Sehoo lake. This eruption was subaerial, for the lake lay well below the base of the tuff cone. Partings of basaltic sand in the lower part of the upper member of the Sehoo formation occur locally within a few miles east of Soda Lake and may represent material blown out by this eruption and deposited in the lake. 
FOSSILS OF SEHOO AND INDIAN IAKES AGE

Fossils obtained from the Sehoo and Indian Lakes formations include the following:

Fossits of early Sehoo age.-A horse jawbone and a metapadial leg bone of a camel were obtained from gravel of the lower member of the Sehoo about 20 feet below the surface in a deep gravel pit, $71 / 2$ miles southeast of Salt Wells, sec. 26 (unsurveyed), T. 17 N., R. 31 E., operated by the Tedford Brothers of Fallon. The horse maxilla was determined by R. A. Stirton, Department of Paleontology, University of California, Berkeley, to be Equus, sp., undoubtedly a relatively recent form. The camel metapodial was determined by Jean Hough, U.S. Geological Survey, to be Camelops?. Probably also of early Sehoo age are the bones of three extinct vertebrates from a gravel pit at Astor Pass, 4 miles northwest of Pyramid Lake, identified by Merriam (1917) as Felis atrox Leidy, a lion), Camelid, near Camelops, and Equus sp., probably near E. pacificus, or possibly E. occidentalis. The Astor Pass gravel pit is above 4,200 feet and likely above the middle Sehoo lake; hence the gravel and tufa in the upper part of the deposit that yielded the bones probably is in the lower member of the Sehoo.

Fish bones that weathered out from clay of the lower member of the Sehoo 1 to 2 feet above the Sehoo-Wyemaha contact, about 1 mile south of Carson Sink and 3 miles northeast of Upsal Hogback (sec. 7, T. 21 N., R. 29 E.), were identified by D. H. Dunkle, U.S. National Museum, as a "mixture of perhaps two suckers (family Catostomidae), carp (family Cyprinidae), and possibly also bullhead (family Cottidae)."

Snails were collected from gravel, sand, and silt of the lower member of the Sehoo at 18 localities (table 6 and p. 51-59), ranging in altitude from 4,090 to 4,330 feet. They were determined by Joseph P. E. Morrison, U.S. Geological Survey, to be solely of one species, Parapholyx nevadensis Henderson, in all but one collection; the snails varied toward $P$. [nevadensis] pusilla F. C. Baker in three collections and toward $P$. nevadensis solida Dall in two collections. One collection contained Vallonia cyclophorella Ancey, in addition to Parapholyx nevadensis, variety toward pusilla. All are aquatic species.

Each of the fossil forms from the lower member of the Sehoo is still living in North America, except the mammalian vertebrates, which suggest a late Pleistocene age. The predominance of the snail Parapholyx nevadensis here, in contrast to the more general and larger list of mollusks from the lake deposits of Fallon age suggests a difference in lake ecology-possibly colder water.
Fossils of thinolite recession age.-Vertebrate bones were obtained from the middle tongue of the Indian Lakes formation in pit $\mathrm{N} 6$ at Hidden Cave (unit 10 in section 39, table 10). They were identified by Seth B. Benson, Museum of Vertebrate Zoology, University of California, Berkeley, and E. C. Furlong, Department of Vertebrate Paleontology, California Institute of Technology, as one individual each of :

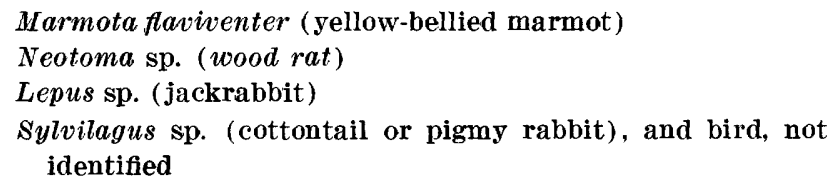
identified

Each form is still living in the area.

Fossils of middle Sehoo age.-Fish bones in a slab of lacustrine limestone from the middle member of the Sehoo in pit N6 at Hidden Cave (top of unit 9, in section 39, table 10), were determined by D. H. Dunkle, U.S. National Museum, as similar to those described above from clay of the lower member of the Sehoo. Another collection from the same horizon was identified by Ira LaRivers, Department of Biology, University of Nevada, as containing the fish Siphateles, probably $S$. bicolor obesus, the Lahontan Tui chub, and the ostracod Cyprinotus sp., possibly $C$. dentatus Sharpe. All these forms are still living and are not diagnostic of age.

Fossils of late Sehoo and Indian Lakes age.-The slope-wash gravel of late Sehoo and Indian Lakes age of the Indian Lakes formation in Hidden Cave (unit 7 in section 39, table 10) yielded many mammal and bird bones and a few seeds and mussel (Anodonta sp.) shells, which were probably carried to the site by Indians. The mammal bones were identified by S. B. Benson and staff, University of California, Berkeley, as the following (each species is still living in the area except those starred, which have become extinct within the last century) :

Myotis sp. (mouse-eared bat, 1 individual)

$M$ ustela frenata (long-tailed weasel, 1 individual)

Vulpes fulva (red fox, 1 individual)

*Canis lupus (wolf, 1 individual)

Citellus sp. (ground squirrel, 1 individual)

Dipodomys (kangaroo rat, 2 individuals)

Neotoma sp. (wood rat, 13 individuals)

$N$. lepida (desert wood rat, 7 individuals)

$N$. cinerea (bushy-tailed wood rat, 6 individuals)

Marmota flaviventer (yellow-bellied marmot, 13 individuals )

Lepus californicus (blacktailed jackrabbit, 6 individuals) Slyvilagus sp. (cottontail or pigmy rabbit, 7 individuals) Odocoileus hemionus (blacktail or mule deer, 1 individual) Ovis canadensis (mountain sheep, 1 individual)

*Bison (bison, 1 individual) 
LAKE LAHONTAN: GEOLOGY, CARSON DESERT, NEV.

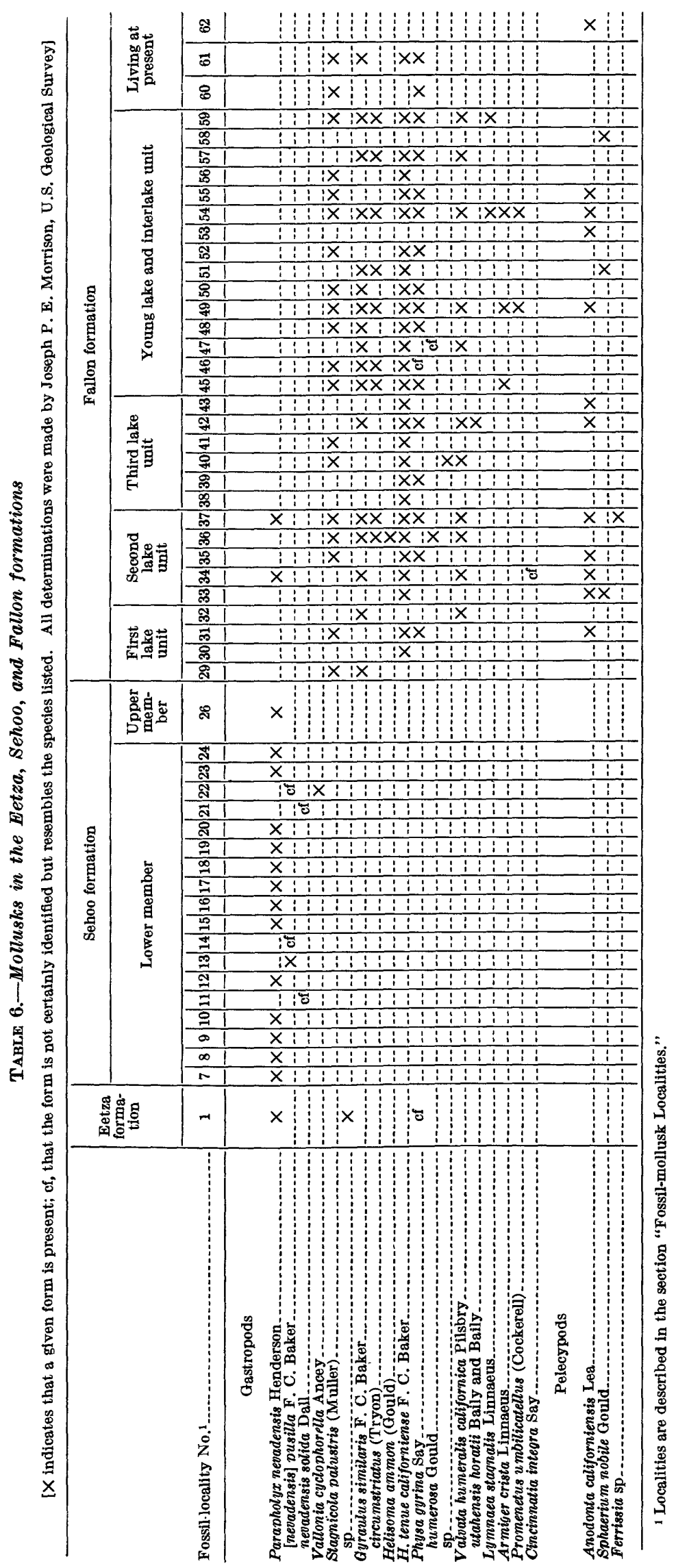


S. M. Wheeler collected a horse bone during his excavations in this cave in 1940 , from a bed that N. L. Roust (written communication, 1956) tentatively correlates with the slope-wash gravel of late Sehoo and Indian Lakes age. E. C. Furlong, Department of Vertebrate Paleontology, California Institute of Technology, identified the bones as Equus occidentalis, which apparently became extinct at the end of the Pleistocene.

Bird bones from the slope-wash gravel of late Sehoo and Indian Lakes age in pit N6 at Hidden Cave were determined by Hildegarde Howard, Los Angeles County Museum (forms now extinct in the area are starred) as follows:

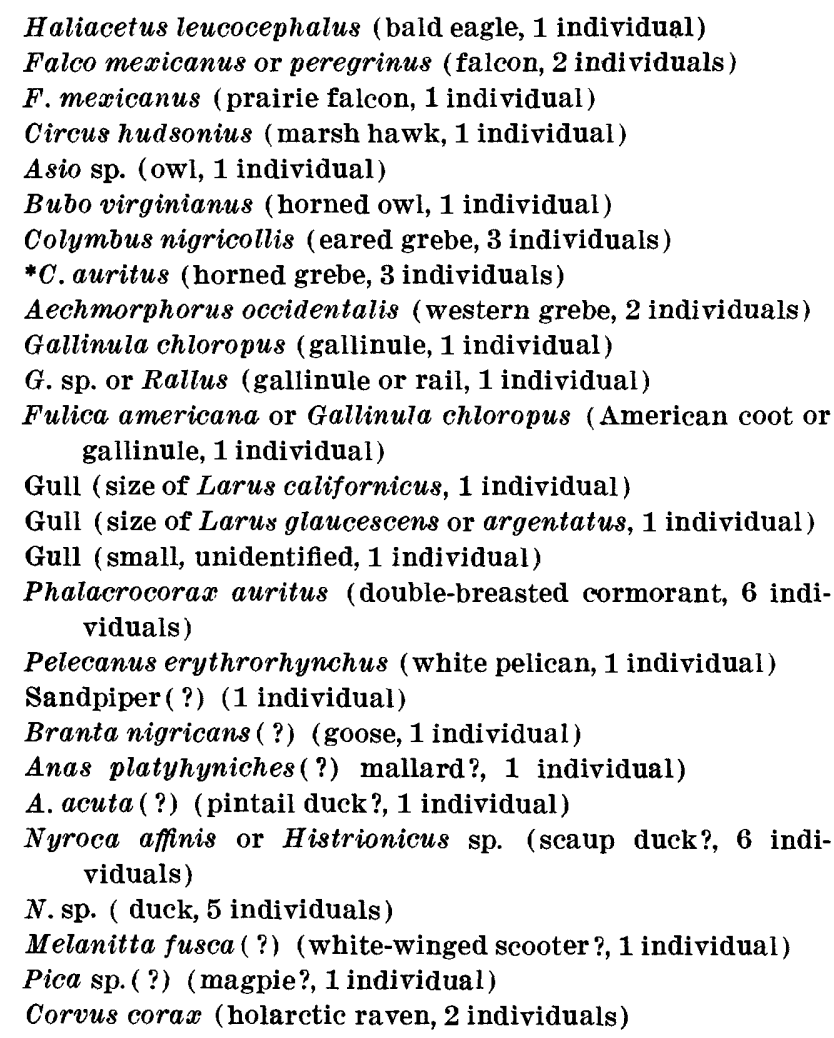

This gravel also yielded plant seeds identified by H. L. Mason, Department of Botany, University of California, Berkeley, as Amsinkia sp. (yellow forget-me-not, or "fiddleneck"). A few fresh-water mussel shells were found, probably Anodonta californiensis.

The richness of this layer in vertebrate species and individuals, compared with the post-Sehoo deposits in the cave, suggests a more abundant vertebrate fauna than subsequently. The preponderance of modern species and probably occurrence of $E$ quus occidentalis suggests a late Wisconsin age.

\section{SOILS OF SFHOO AND INDIAN LAKES AGE}

Two very weakly developed soils are intercalated with the Sehoo and Indian Lakes formations. Both are seen only where buried by deposits of Sehoo and Indian Lakes age, because relict occurrences are masked by the younger considerably stronger Toyeh soil.

\section{INCIPIENT UNNAMED SOIL OF MIDDLE INDIAN LAKES AGE}

The lower soil, not named, is a barely discernible incipient weathering profile that developed beneath the disconformity between the lower and dendritic members of the Sehoo formation, which represents the same time interval as the middle tongue of the Indian Lakes formation, or part of this interval. This soil is at most 2 or 3 inches thick, and shows very weak prismatic structure and brownish discoloration of the parent material without obvious soil zonation; it is rarely preserved. It is exposed in the saddle between Eetza Mountain and Sehoo Mountain (pl. 8 and sections 41 and 42 , table 10) at altitudes as low as about 3,990 feet.

\section{HARMON SCHOOI SOIL}

The upper soil of Sehoo and Indian Lakes age is called the Harmon School soil, after an abandoned school two-thirds of a mile south of its type locality. It occurs only where buried beneath the upper member of the Sehoo, in places of little or no wave erosion; it has not been found below an altitude of 3,920 feet. The soil generally is developed on colluvium of the upper tongue of the Indian Lakes formation or beneath the disconformity within the Sehoo formation that represents this member. Where best preserved, it consists of 1 or 2 inches of brownish clay having weak prismatic structure over a horizon of very weak calcium carbonate accumulation several inches thick. Its type locality is the site of section 17 (table 10 ; see also profile $17 \mathrm{~S}$, table 11) in SW1 $14 \mathrm{NW}^{1} / 4$ sec. 24 , T. 19 N., R. 29 E. Its profile here is modified by the superposed $\mathrm{C}_{\mathrm{ca}}$ horizon of the Toyeh soil; such a modified profile characterizes most occurrences of the soil west of the Sagouspe fault scarp.

\section{TURUPAH FORMATION GENERAL FEATURES}

The Turupah formation is the youngest in the Lahonton Valley group. It consists of eolian sand and alluvium, overlying the Sehoo formation and underlying the Toyeh soil and Fallon formation. These subaerial sediments range in altitude from far above the Lahontan beach to within a few feet of the lowest parts of the basin floor. They, and a widespread disconformity that represents the same time interval, record a time when Lake Lahontan generally was completely dry.

The type locality of the Turupah formation (Morrison, 1961a) is the exposure of eolian sand northwest of Turupah Flat that extends about $1 / 2$ mile on each side 
LAKE LAHONTAN: GEOLOGY, CARSON DESERT, NEV.

of the side road south from U.S. Highway 50 , from the $\mathrm{NW}^{1} / 4$ sec. 33 to the SE1/4 sec. 29 , T. 18 N., R. 30 E. This sand disconformably overlies clay of the Sehoo, locally bears the Toyeh soil, and is overlain by eolian and lacustrine sand of the Fallon formation.

Section 16 (table 10) shows typical stratigraphic relations of the eolian sand to the Toyeh soil and the Sehoo and Fallon formations.

\section{EOLIAN SAND}

Distribution, morphology and stratigraphic relations.-Eolian sand is the characteristic and most extensive deposit of the Turupah formation. It occurs in dunes and small ergs (extensive dune complexes), and attains a maximum thickness of about 30 feet. It is mapped only in the eastern quadrangles, but it is also widespread in the western quadrangles. It ranges in altitude from above the Lahontan beach to 3,875 feetalmost to the bottom of the basin. The lowest occurrences are at Pelican Island and Battleground Point (on the south edge of Carson Sink), and in the eastern part of the Indian Lakes area, where it is mostly buried by lake and eolian sand of the Fallon formation (here its subsurface distribution was studied by many auger holes).

The original dune forms are still evident in places, and are similar in type, distribution, orientation, and probably in size and shape to the present dunes (p. 80$85)$. In the highlands this eolian sand is less extensive than the original distribution of eolian sand of the Wyemaha formation, for it is absent from many slopes and canyons where remnants of the older sand are preserved.

In the lowlands the eolian sand commonly overlies the Sehoo formation, or locally the Wyemaha, with marked disconformity owing to deflation of basininterior sediment. It generally is overlain by eolian sand of the Fallon formation above the highest level of the younger lakes ( 3,948 feet), and by both eolian sand and lake sediment of the Fallon below this altitude (fig. 31).

Its distribution and associated deflation features show that the windblown sand came mainly from the Sehoo and Wyemaha formations in the Western half of the Carson Desert. Much of the eolian sand on the late Sehoo deltas was derived from local lake sand.

Lithology.-The eolian sand is generally fine-medium to medium sand; locally it contains considerable coarse sand, grit, and even small pebbles. It is pale yellowish gray to off-white, unindurated except where cemented by the Toyeh soil, and has obscure to distinct stratification-either parallel, inclined, or crossbedded. Locally it contains coprolites (probably coyote) and rodent bones. The coarsest deposits are on the west late Sehoo delta and eastward to the S-line Reservoir. At this reservoir the sand contains many fragments of late lithoid tufa of the upper member of the Sehoo, mostly less than an eighth of an inch across. Near Salt Wells some beds contain 5 to 30 percent tufa granules.

Volcanic-ash parting.-A parting of white pumiceous ash, $1 / 8$ to rarely as much as $3 / 4$ inch thick, occurs locally in the lower part of the eolian sand. This parting is highly discontinuous and cannot be traced more than a few feet at any given locality. It is not certain that it is everywhere a single horizon, although no more than one ash layer was seen at any one locality. This parting can be seen at the following localities: (a) about a quarter of a mile southeast of Salt Wells; (b) in a road cut 2.8 miles west of Salt Wells, on the north side of Turupah Flat; (c) within a few hundred feet of the west edge of the northwest prong of the Bunejug Mountains; (d) near Mahala siding on the railroad, 10 miles west of Fallon; and (e) in a road cut on the west side of the Carson River flood plain 6 miles northnortheast of Fallon and 2 miles south of Wolf Dam. A similar ash parting locally overlies sand of the upper

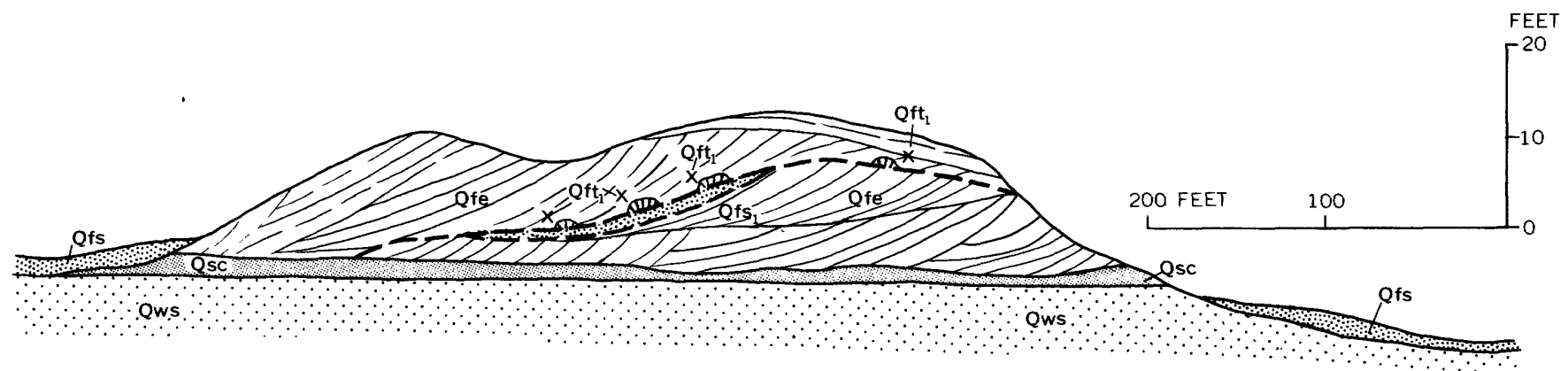

FigdRE 31.-Diagrammatic cross section showing relations of the Fallon, Turupah, Sehoo, and Wyemaha formations one-half mile northeast of the S-Line Reservoir, NE1/4 sec. 22 , T. 19 N., R. 29 E. Qfe, and Qfs, eolian and lake sands, respectively, of the Fallon; Qte, eolian sand of the Turupah: Qsc, clay of the Sehoo: Qws, lake sand of the Weyemaha. Deflation during Turupah time eroded deeply into the Sehoo formation, and in places entirely through it. Between the eolian sands of the Turupah and Fallon formations is a local selvage of lake sand $\left(\mathrm{Qfs_{1 }}\right)$ and tufa $\left(Q \mathrm{ft}_{1}\right)$ of the first lake unit of the Fallon formation. 
member of the Sehoo, within a few inches of the surface, along the south and west borders of Eightmile Flat.

Associated deflation basins and deflation plains.-In the lowlands eolian sand of the Turupah formation generally lies upon a widespread erosion surface that was carved into the Sehoo and Wyemaha formations and is characterized by deflation basins and deflation plains rather than by fluvial features. The deflation features are most prominent in the lowlands of the northwestern half of the area. Dozens of deflation basins, half a mile to several miles wide, are scooped commonly 20 to 40 feet, and rarely 60 feet and more below the top of the Sehoo formation; in places deflation has eroded entirely through this formation and as much as 30 feet into the Wyemaha formation. Carson Sink is a huge deflation plain; its southwestern part is so strongly deflated that the Sehoo formation generally has been entirely stripped away. This plain continues about 7 miles southwestward from the southwest corner of the sink past both sides of Upsal Hogback. On the late Sehoo deltas deflation was insignificant on pebbly sand of the Indian Lakes formation in distributary channels, but it was commonly considerable in the basins that were eroded in the finer interchannel deposits of the upper member of the Sehoo. Lesser deflation affected all other large exposures of clay of the Sehoo formation, such as Bass Flats, Turupah Flat, and Eightmile Flat. Probably more than one-half cubic mile of sediment was deflated from the lowlands of the map area.

\section{LOESS}

Quantitatively insignificant, yet conspicuous in parts of the highlands, is a blanket of loess of Turupah age. It ranges from less than 1 inch to rarely more than 1 foot in thickness, is mostly silt and fine sand, and is generally indistinctly bedded and unconsolidated; some slope wash is intercalated locally. The loess bears the Toyeh soil, where this soil has not been eroded. The loess is most conspicuous on the eastern piedmonts and commonly is barely noticeable on the western ones; it probably was derived mainly by deflation from the lowlands of the Carson Desert and transport and deposition by westerly winds. It is annoyingly evident on the western piedmont of the Stillwater Range, northeast of the map area, because of the dust it causes on unsurfaced roads. The small patches of lake clay and sand of the Fallon formation in ponded areas of the highlands were mostly derived from this loess.

Several caves also contain beds of this loess (without the Toyeh soil). The main loessic deposit at Hidden Cave (unit 6 in section 39 , table 10), is correlated with the Turupah formation because it overlies a slope-wash gravel that is correlated geologically and archaeologically with the late Sehoo and Indian Lakes deposits, and underlies midden, slope wash, and loessic layers that are similarly correlated with the Fallon formation; also it apparently records the maximum eolian activity of post-Sehoo time. It consists of as much as 5 feet of silt and fine sand, which is partly eolian and partly slope wash. In Leonard rockshelter, an important archaeological site in the West Humboldt Range near Lovelock, Nev., the main loessic unit, probably correlative with the Turupah, is correlated with the altithermal age of Antevs (Heizer, 1951).

Near the base of the loess of the Turupah in Hidden Cave is a discontinuous parting of white pumiceous ash $1 / 16$ to $1 / 2$ inch thick. A similar white ash parting was observed near the base of the correlative deposit of altithermal age in Leonard rockshelter (Heizer, 1951). These partings may correlate with the one in the lower part of the eolian sand. Petrographic examination of the ash from both caves indicates that it probably came from Mono Craters, Calif., though not necessarily fom the same eruption (written report, 1950, by Howel Williams, Geology Department, University of California, Berkeley, to R. F. Heizer, Anthropology Department, same university).

\section{ALIUVIAL SAND}

Alluvium of the Turupah formation is exposed in the northwestern Carson Lake and northeastern Fallon quadrangles as discontinuous remnants, 100 to 500 feet wide, that rise a few feet above the present flood plain. These define a former channel complex of the Carson River that commenced half a mile south of Fallon and meandered eastward for 6 miles. The complex is partly a single and partly a double channel, having a gradient of about $4 \frac{1}{2}$ feet per mile-about the same as the present flood plain. Below an altitude of 3,930 feet it is concealed beneath the Fallon formation, but it has been traced in the subsurface about half a mile northeastward where it is almost 10 feet lower (section 18, table 10).

Sand pits in this alluvium show as much as 15 feet of indistinctly stratified fine-pebbly coarse sand and some medium sand, which is relatively homogeneous except for a foot or so of silty sand at the top which may be younger lake sand. The pebbles are gneissic, granitic, and volcanic rocks similar to those in the present bed of the Carson River. The alluvium bears the Toyeh soil, attesting to its pre-Fallon age.

Many local exposures of Carson River channel sand of probable Turupah age have been found in drainage canal banks. The lowest is at the bottom of the Carson Lake drainage canal, at the quarter-section corner be- 
LAKE LAHONTAN: GEOLOGY, CARSON DESERT, NEV.

tween secs. 32 and 33 , T. 18 N., R. 29 E. (section 48, table 10). Here $21 / 2$ feet of pebbly coarse sand containing pebbles to $1 / 2$ inch in diameter is exposed above water level; the altitude of the upper contact is about 3,913 feet.

\section{DISCONFORMITY COEVAL WITH THE TURUPAH FORMATION;} EVIDENCE OF COMPLETE LAKE DESICCATION

The disconformity of Turupah age is particularly widespread in the basin interior. It has been observed as low as 3,875 feet along the southern margin of Carson Sink. Its deflation features and their effect on the upper contact of the Sehoo have been discussed above. That the Carson Desert was at least as dry as now for long periods is shown by the amount of deflation in the low areas. Even where marked erosion is not evident, subaerial exposure is manifest by soil development, mud cracks, clastic dikes, and plant remains. Probably complete lake disiccation during Turupah time also is indicated by the minimum altitudes reached by the Turupah formation- 3,875 feet for eolian sand and below 3,910 feet for alluvium.

\section{FOSSILS}

Two collections of bones from coyote(?) coprolites in eolian sand of the Turupah, from the east shore of S-Line Reservoir and from 1 mile northwest of Harmon School, were examined by H. W. Stetzer, U.S. Geological Survey, who identified the following genera of rodents: Reithrodontomys (harvest mouse), Citellus (ground squirrel), and Sylvilagus (cottontail and allied rabbits).

\section{TOYBA. SOIL}

\section{STRATIGRAPHIC RELATIONS AND OCCURRENCE}

Overlying the Turupah formation is a soil that has a moderately developed profile. It is called the Toyeh soil, after Mount Toyeh, an old name for Rattlesnake Hill, which is near its type locality. Typically it is a Gray Desert soil, although in relatively saline locations it grades toward a Solonchak or Solonetz soil. The Toyeh soil is considered to mark the top of the Pleistocene deposits in this area (Morrison and others, 1957, p. 390; Morrison, 1961d).

The Toyeh is the most widely distributed soil in the area. It is not only widespread on the lowlands-to at least as low as 3,890 feet-but also is nearly the only soil in the highlands below the highest shoreline of the early Sehoo lake, because the Churchill and Cocoon soils generally have been either eroded or buried by younger sediment. It also is widespread above this shoreline. This soil is considerably weaker than the Cocoon and Churchill soils, but is much more strongly developed than the soils of Eetza, Sehoo, or Fallon age, and is one of the most useful stratigraphic markers. It is not evident on relicts of the Cocoon and Churchill soils, because it is masked by the stronger development of the older soils.

Type locality.-The type locality of the Toyeh soil is the site of soil profile section $16 \mathrm{~S}$ and stratigraphic section 16 (tables 11 and 10 , in the bluff on the east side of a wash about $1 / 3$ mile east of the northeast corner of the S-Line Reservoir. The soil is on eolian sand of the Turupah formation and is buried by a few feet of younger eolian sand. The very top of the soil appears eroded here but an example of the full profile can be seen at the site of stratigraphic section 32 (table 10) and soil profile section 32 (table 11), which is typical of relict occurrences on the Sehoo formation above the late Sehoo lake.

\section{PROFILE CHARACTERISTICS}

The Toyeh soil differs from the Churchill and Cocoon soils by being considerably thinner, less strongly developed, and by having less sharply differentiated horizons. Its full thickness is generally about 10 to 14 inches in sand and gravelly sand, but it ranges from as much as 20 inches in gravel to as little as 8 inches in clay. At its top is a vesicular (A) horizon; beneath this an oxide (B) horizon, and a horizon of calcium carbonate accumulation $\left(\mathrm{C}_{\mathrm{ca}}\right)$ (fig. $\left.30, B, C\right)$. The oxide and calcareous horizons overlap gradationally; clay and oxide accumulation is greatest at the top, and calcium carbonate accumulation greatest below. The full profile of this soil is preserved more commonly than that of the older soils.

The profile varies more with variations in parent material and other local environmental factors than do the Churchill and Cocoon soils, not only in total thickness, but also in details of the $\mathrm{B}$ and $\mathrm{C}_{\mathrm{ca}}$ horizons. For example, the B horizon is weakly developed in clean gravel, but well developed in silty or clayey sand and gravel, where fines were available for illuviation; the $\mathrm{C}_{c a}$ horizon obviously is best developed in calcareous sediment. The following general horizon descriptions refer only to locations that are relatively flat and well drained, where the soil is relatively uneroded, and where it developed on sand or gravel.

A lag-gravel layer about one pebble thick veneers this soil where gravel is present in the underlying sediment, but with a decrease in abundance of pebbles in the parent material the lag gravel becomes discontinuous. The lag gravel is believed to be cogenetic with the soil. In some locations younger drift sand partly covers the lag gravel. Desert varnish is sparingly developed on the outer surfaces of the andesitic and basaltic 
pebbles of the lag gravel--somewhat less than on relict occurrences of the Churchill and Cocoon soils.

The vesicular (A) horizon, characteristic of the top part of the profile of Gray Desert soils, is relatively well developed in the Toyeh soil. It underlies the lag gravel or merges with the lower part of it. It is generally $21 / 2$ to $31 / 2$ inches thick, and is white, very pale brown, light gray, or pale pinkish gray $(10 Y R 8 / 2,8 / 3,7 / 3,7 / 2$ to $7.5 Y R \quad 8 / 2$ and $7 / 2$ ), and characteristically consists mostly of silt and silty sand; even on gravelly parent material and where overlain by lag gravel it contains few pebbles. It generally is somewhat calcareous. It has an almost frothy appearance owing to many small round bubbles or vesicles, which range in diameter from less than $1 / 64$ to rarely more than $1 / 4$ inch. Soil structure is weak to moderate medium to coarse columnar and commonly also weak medium platy. Consistence is slightly hard to hard, friable, harsh, and floury.

The oxide (B) horizon has an abrupt boundary with the vesicular horizon. It generally is 4 to 5 inches thick and is light brownish gray (10YR 6/2), pale brown $(10 Y R 6 / 3)$, to locally brown $(10 Y R 5 / 3)$ or grayish brown $(10 Y R 5 / 2)$, commonly grading somewhat lighter downward. Texture is approximately that of the parent material, although megascopic appearance suggests slight illuviation of clay and silt, which decreases downward. The available mechanical analyses, however, show no significant concentration of clay and silt. Generally at the top is a parting less than $1 / 4$ inch thick, more clayey, more highly aggregated, and more friable than material below. Structure is weak coarse granular to weak coarse prismatic or columnar; consistence, slightly hard to hard. Calcium carbonate generally is nearly completely leached from the upper part of the horizon, but increases gradually downward, and the boundary with the $\mathrm{C}_{\mathrm{ca}}$ horizon is gradual to diffuse.

The calcareous $\left(\mathrm{C}_{\mathrm{ca}}\right)$ horizon is less sharply defined than the other horizons and also varies more in thickness. It commonly ranges from 6 to 14 inches in thickness, is light gray to pale brown, light brownish gray, or pinkish gray $(10 Y R 7 / 2,6 / 1,6 / 2,6 / 3$ and $7.5 Y R 6 / 2)$, and commonly is mottled with whitish spots and streaks of calcium carbonate. Cementation by calcium carbonate is very weak to moderate; consequently the structure varies from nearly single grain to weak coarse granular to weak coarse subangular blocky, and consistence from nearly loose, to soft, to hard. The calcium carbonate concentration generally is so moderate that the $\mathrm{C}_{\mathrm{ca}}$ horizon is inconspicuous in fresh exposures. In weathered exposures, however, the horizon shows as a somewhat resistant pale-gray to white band (fig. $30 D$ ), because the lime is concentrated at the surface by efflorescence. This commonly makes the Toyeh soil a better stratigraphic marker than its true degree of development would warrant.

Modification of the soil profile with stratigraphic occurrence.-The Toyeh soil has everywhere a similar profile, but it naturally shows somewhat greater development where the surface was exposed and stable for long intervals before or after the Toyeh interval. Such extended intervals of exposure had more discernible effect on this soil than similar intervals had on the Churchill and Cocoon soils, because the Toyeh soil is the least strongly developed of the three. The difference in development is most evident in comparing buried occurrences of the soil on the Turupah formation with relict occurrences on the dendritic member of the Sehoo or older units, because the latter had additional increments of weak soil development during the Harmon School and L-Drain soil intervals.

Variation toward Solonchak and Solonetz soils.Locally in the lowlands the Toyeh soil formed on saline silt or clay of the Sehoo formation, or where poor drainage has caused salt and alkali accumulation. In such places its profile varies toward a Solonchak or Solonetz soil, rather than the typical Gray Desert soil type. The vesicular horizon generally is lacking; instead, the A horizon consists of a light-gray (about 2.5Y 7/2), highly saline, surface crust about $1 / 4$ inch thick, and an underlying layer, one-half to several inches thick, of light-gray to gray to grayish-brown (about $2.5 Y$ $7 / 2$ to $5 / 2$ ) highly flocculated (aggregated) clay loam or clay having a strong fine granular structure and loose to fluffy consistence. The B horizon commonly is darker than in the Gray Desert soil facies-light brownish gray, grayish brown, to dark grayish brown (about $10 Y R$ or $2.5 Y 6 / 2$ to $4 / 2)$; it is moderately compact, and has a structure ranging from strong columnar (Solonetz soil) to granular (Solonchak soil). The $\mathrm{C}_{c a}$ horizon generally is telescoped to less than 9 inches thick, as usual on impermeable parent materialbut the calcium carbonate cementation is correspondingly stronger than normal.

\section{FALLON FORMATION}

\section{GENERAL FEATURES}

The Fallon formation consists of subaerial and shallow-like sediments of Recent age directly overlying the Turupah formation and the Toyeh soil. It was named (Morrison, 1961a) after Fallon, near which it is extensively exposed. This formation is thinner and smaller in volume than the Lahontan Valley group, yet is more widely exposed. It is the dominant unit in the lowlands and is widespread in the highlands except in the steeper parts of the mountains. 
This formation, though mapped as a unit, has generally been subdivided in stratigraphic sections. Its sediments have been studied in special detail because of the perfection of its record of Recent lake fluctuations in the Carson Desert. This record reflects the Recent climatic changes in the region because the Carson Desert is the terminus for the principal and most representative drainage basin.

The Fallon formation is subdivided into two members, lower and upper (fig. 32), in stratigraphic sections

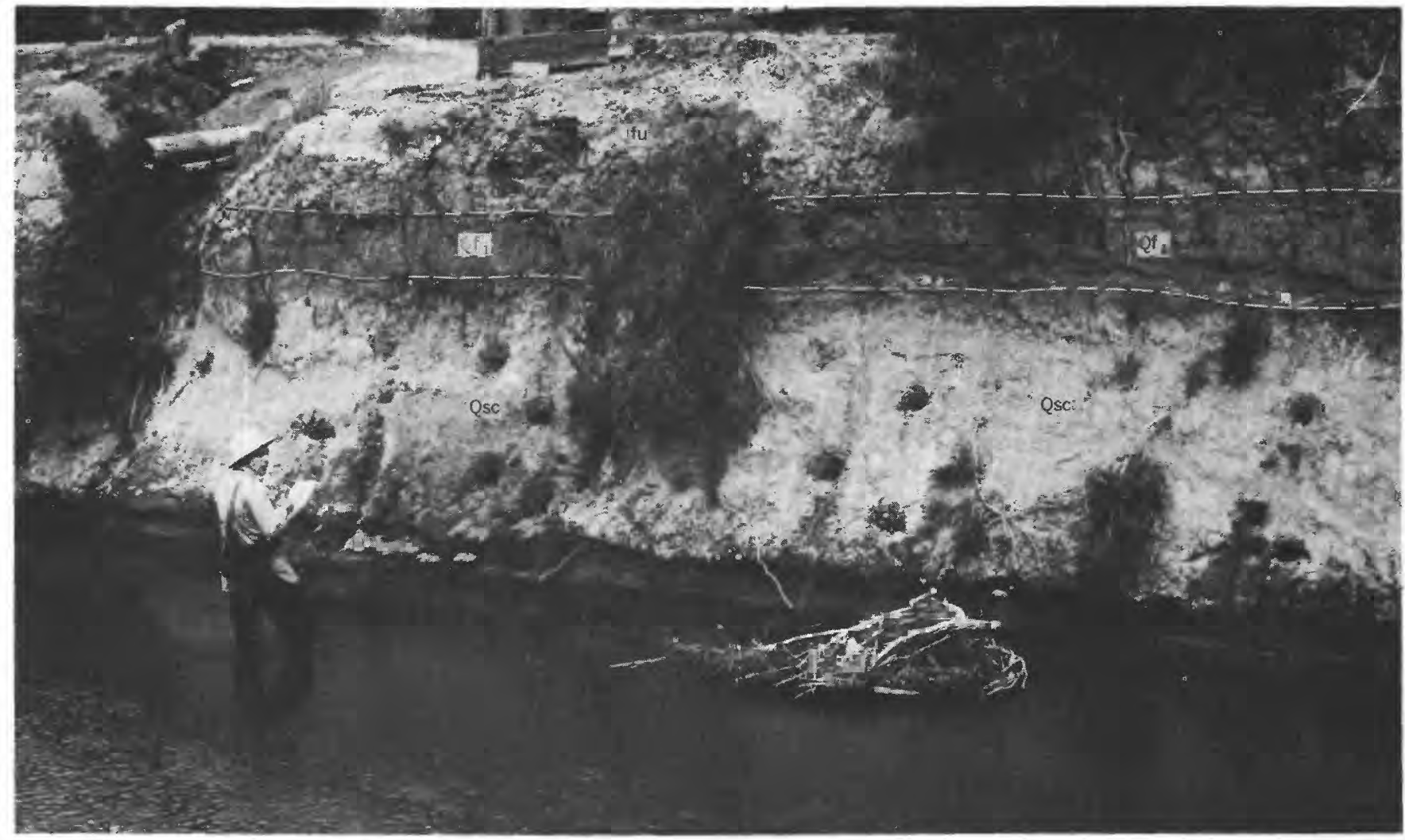

FIGURE 32.-Fallon formation disconformable on Sehoo formation; the disconformity represents the time of the Turupah formation. Top $11 / 2$ feet is lacustrine silt and sand of npper member of the Fallon formation (Qfu); next 2 feet is carbonaceous silty clay of the lower member of the Fallon (Qfl) with ash partings at top and bottom; remaining $5 \% / 4$ feet to water line is clay of the dendritic and lower members of the Sehoo (Qsc); Stillwater Slough at Kent Ranch, SW 1/4 sec. 8, T. 19 N., R. 31 E. ; water level about 3,885-3,890 feet altitude.

at altitudes below or only slightly above the highest shores of the Fallon lakes. Both members consist of shallow-lake sediments and intertonguing subaerial sediments. The entirely subaerial sediments at higher altitudes are not subdivided.

\section{LOWER MEMBER}

The lower member is the thicker. It includes sand, silt, clay, gravel, and tufa of the first two lakes (lake cycles) of Fallon time, Fallon lakes 1 and 2, whose maximums were at altitudes of about 3,948 and 3,930 feet, respectively. It also includes alluvium and eolian sand, which were deposited partly during the lake cycles and partly during intervening and succeeding intervals of lake recession. This member is differentiated only below the highest level of the first lake, except for the alluvium and eolian sand that intertongue with the lake sediments and locally can be traced higher.

The type locality is the Fallon Naval Auxiliary Air
Station reservation (as of 1950 - not as subsequently enlarged), secs. 14, 15, 22, and 23, T. 18 N., R. 29 E. The plain on which the station is located is a compound delta of the Carson River that was built into the first and second Fallon lakes. Sections 18, 22b, $23,35,37,47$, and 48 (table 10) illustrate typical lithology and stratigraphic relations of the member.

The lower member conformably overlies the Toyeh soil, except locally where the soil was eroded by wave action of the first Fallon lake. This soil is a relatively conspicuous and easily traceable marker for the lower boundary. The upper boundary lies at the top of the second interlake unit of the Fallon formation (table 7). The L-Drain soil locally represents this unit, but this weak soil is a poor marker.

\section{UPPER MEMBER}

The upper member consists of late Recent to presentday intertonguing subaerial and shallow-lake sedi- 
ments that overlie but are very similar to those of the lower member. They record at least three very shallow lake cycles, called the third, fourth, and fifth Fallon lakes, separated and followed by virtually complete desiccation. This member is differentiated only below (and locally slightly above) the highest level of the third Fallon lake-altitude about 3,922 feet in the Carson Lake area and about 3,915 feet in the rest of the basin.

The type locality is the Raymond Cushman Ranch, in secs. 28,29 , and 33, T. 18 N., R. 29 E. The member here consists of lake sand that was deposited in a small delta of the Carson River at the high shore of the third Fallon lake.

\section{LAKE AND INTHRLAKE UNITS}

Both members commonly are further subdivided in stratigraphic sections into lake and interlake units on the basis of their intertonguing units of subaerial and lacustrine sediments, and this stratigraphy is summarized in table 7. Morrison and others (1957, p. 388390) have pointed out the posssible utility of these units in recording Recent climatic history and subdivisions of Recent time in the Lake Lahontan area.

\section{EOLIAN SAND}

Distribution.-Eolian sand is one of the most widely distributed sediments of the Fallon formation. It ranges from tiny sand drifts a few inches thick to extensive dune complexes (ergs) many square miles in area and locally more than 50 feet thick. Its distribution is controlled by the locations of source areas-chiefly expanses of sand of the Wyemaha and Sehoo formations-by direction and amount of wind transport, and by local topography which favors deposition.

This sand underlies at least one-fifth of the northern and western lowlands, and more than half of large parts of this area. It was not mapped in the Fallon and Soda Lake quadrangles, in order to simplify map patterns, and it is even more extensive than the geologic maps of the Carson. Lake and Stillwater quadrangles show, because large tracts are drift sheets too thin to be mapped. Few places in the lowlands are free from it, for almost every shrub lodges some drift sand, but it is rare on Carson Sink and the other playa flats because these bare expanses favor deflation and transport, not lodgement, of sand. It also is scarce in the Carson Lake and Stillwater Lakes areas because the sand was stopped by peripheral vegetation, even when the lakes were dry.

TABLE 7.-Subdivisions of the Fallon formation

[Chart showing general summary is given below; detailed description follows chart]

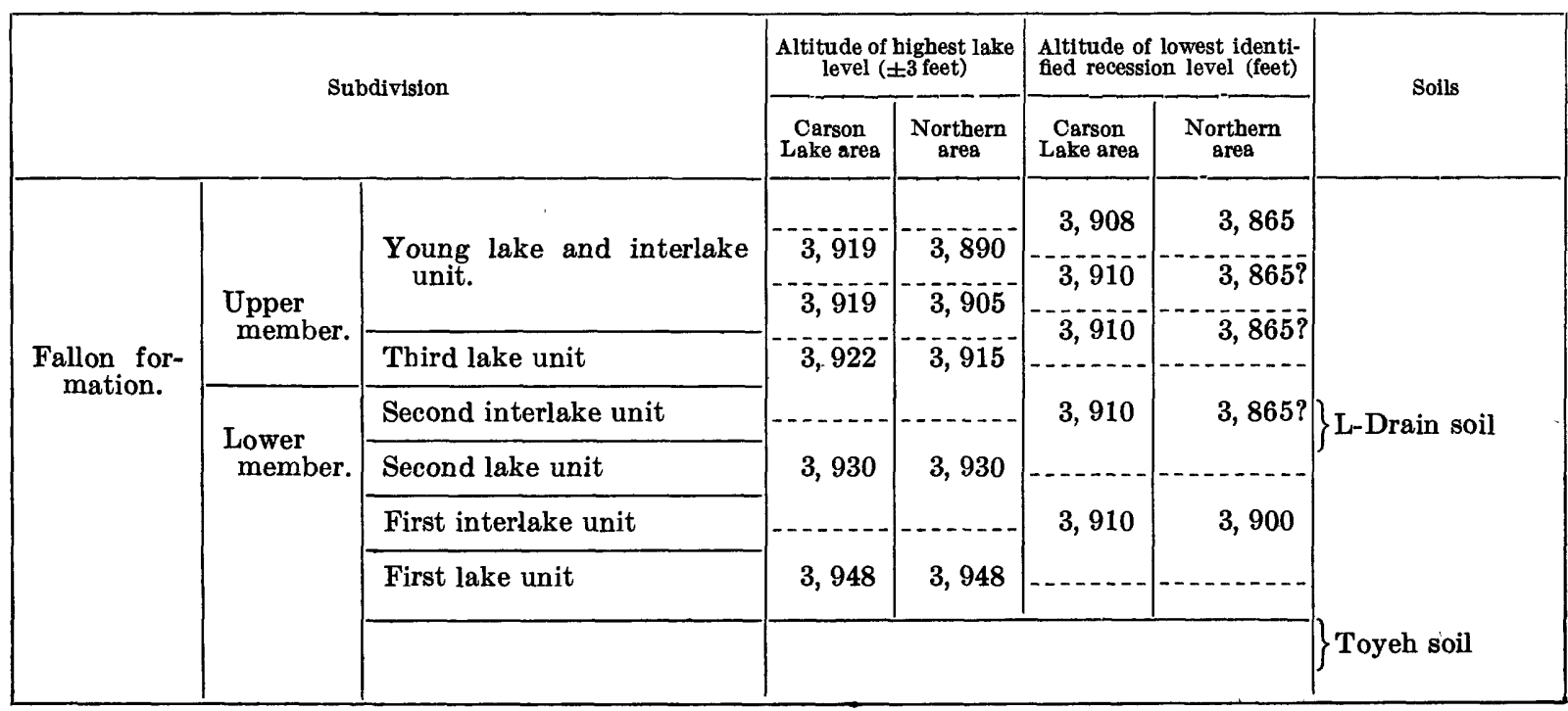


TABLE 7.-Subdivisions of the Fallon formation-Continued

\begin{tabular}{|c|c|c|c|c|}
\hline$\underset{\text { ber }}{\text { Mem- }}$ & Unit & Definition and type locality & Lake history recorded & Sediments and shore features \\
\hline \multirow{2}{*}{ 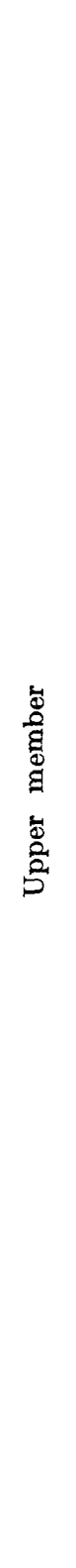 } & 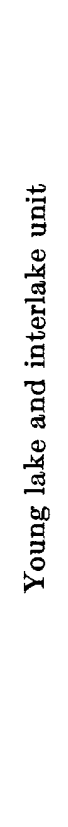 & $\begin{array}{l}\text { Youngest part of Fallon for- } \\
\text { mation, includes present- } \\
\text { day deposits and overlies } \\
\text { third lake unit. Contains } \\
\text { very shallow lake sedi- } \\
\text { ments (probably } 2 \text { main } \\
\text { tongues in Carson Lake } \\
\text { area representing fourth } \\
\text { and fifth Fallon lakes, and } \\
2 \text { or more tongues in north- } \\
\text { ern area) and intertonguing } \\
\text { and coeval alluvium and } \\
\text { eolian sand. } \\
\text { Type locality: Lowermost of } \\
\text { two small gravel bars at } \\
\text { base of Wildcat scarp, } \\
\text { NW14 sec. 3, T. 16 N., R. } \\
29 \text { E., (fig. 33) which marks } \\
\text { highest (congruent) shore- } \\
\text { lines of both lakes in } \\
\text { Carson Lake area. }\end{array}$ & $\begin{array}{l}\text { In Carson Lake area, fourth } \\
\text { and fifth Fallon Lakes, } \\
\text { maximums (congruent) } \\
3,919 \mathrm{ft} \text {; also preceding, } \\
\text { intervening, and follow- } \\
\text { ing desiccation intervals. } \\
\text { Carson Lake probably } \\
\text { overflowed to northern } \\
\text { area via Stillwater Slough } \\
\text { during both maximums. } \\
\text { History in northern area } \\
\text { less certain hecause of } \\
\text { correlation difficulties; } \\
\text { prohablv several very } \\
\text { small lake cycles; two } \\
\text { main maxima at ahout } \\
3,905 \text { and } 3,890 \mathrm{ft} \text {. Last } \\
\text { maximums in both areas } \\
\text { occurred about 1862 A. } \\
\text { D. See text for river } \\
\text { history. }\end{array}$ & 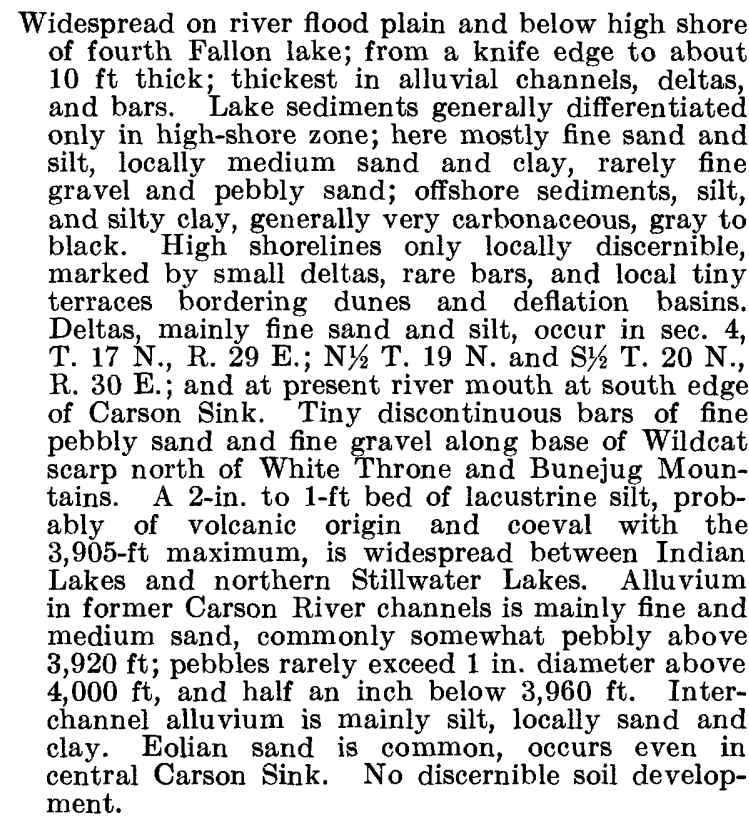 \\
\hline & 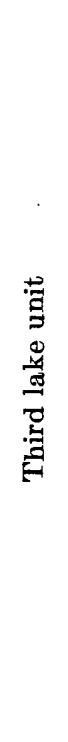 & $\begin{array}{l}\text { Third youngest lacustrine } \\
\text { tongue in Fallon forma- } \\
\text { tion: lake sand, silt, clay, } \\
\text { local lake gravel and tufa; } \\
\text { also coeval alluvial sand } \\
\text { and silt. } \\
\text { Type locality: Uppermost of } \\
\text { two small bars at base of } \\
\text { Wildcat scarp north of } \\
\text { White Throne Mountain, } \\
\mathrm{NW} 1 / 4 \text { sec. } 3, \mathrm{~T} \text {. } 16 \mathrm{~N} ., \mathrm{R} . \\
29 \mathrm{E} \text {. (fig. 33). This bar } \\
\text { marks highest shore of } \\
\text { third Fallon lake. }\end{array}$ & $\begin{array}{l}\text { Third Fallon lake. In Car- } \\
\text { son Lake area, maximum } \\
\text { was at an altitude of } \\
\text { about } 3,922 \mathrm{ft} \text {, when this } \\
\text { lake overflowed to north- } \\
\text { ern area. In northern } \\
\text { area, maximum was about } \\
3,915 \text { ft and approxi- } \\
\text { mately coeval with that } \\
\text { in Carson Lake area, hut } \\
\text { possibly slightly earlier } \\
\text { or later. }\end{array}$ & 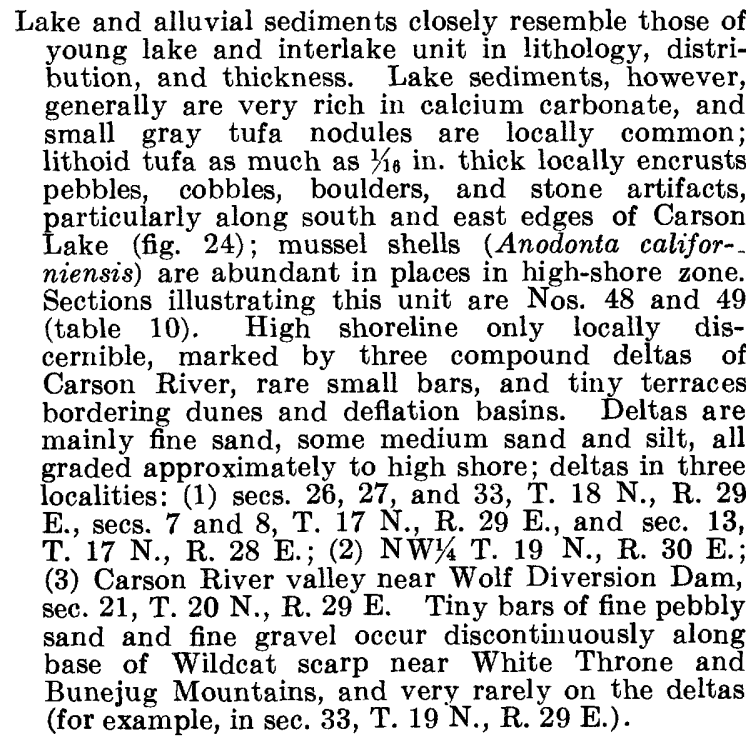 \\
\hline
\end{tabular}


TABLE 7.-Subdivisions of the Fallon formation-Continued

\begin{tabular}{|c|c|c|c|c|}
\hline$\underset{\text { ber }}{\text { Mem- }}$ & Unit & Definition and type locality & Lake history recorded & Sediments and shore features \\
\hline \multirow{3}{*}{ 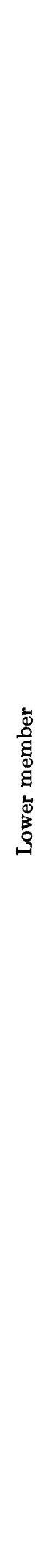 } & 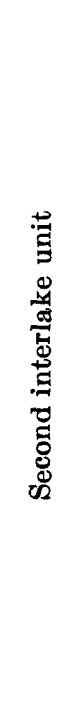 & $\begin{array}{l}\text { Second youngest interlacus- } \\
\text { trine tongue of Fallon for- } \\
\text { mation, intermediate in } \\
\text { age between the first and } \\
\text { second lake units: eolian } \\
\text { sand, alluvium, and very } \\
\text { shallow lake sediments; ap- } \\
\text { proximately coeval with } \\
\text { the L-Drain soil. } \\
\text { Type locality: Greenhead } \\
\text { Duck. Club, sec. 9, T. } 17 \\
\text { N., R. } 29 \mathrm{E} \text {. }\end{array}$ & $\begin{array}{l}\text { Second youngest lake reces- } \\
\text { sion of Fallon time, to at } \\
\text { least as low as } 3,910 \mathrm{ft} \\
\text { in Carson Lake area and } \\
3,880 \mathrm{ft} \text { in northern area; } \\
\text { probably desiccation was } \\
\text { complete at times, par- } \\
\text { ticularly in northern area. }\end{array}$ & $\begin{array}{l}\text { Sediments generally differentiated only where over- } \\
\text { lain by lake sediments of third lake unit; sparse; } \\
\text { less than } 1 \text { to rarely } 5 \mathrm{ft} \text { thick. Chief occurrences } \\
\text { are: (a) The delta at the type locality, where } \\
\text { alluvial and lake sand and silt overlie clay of the } \\
\text { second lake unit and are overlain by silt, clay, and } \\
\text { sand of the third lake unit; delta is graded to a } \\
3,911-3,915 \mathrm{ft} \text { shoreline, that is, close to present } \\
\text { level of Carson Lake; (b) east and south shores of } \\
\text { Carson Lake to base of Wildcat scarp, where there } \\
\text { is eolian sand as low as } 3,912 \mathrm{ft} \text {, alluvium down to } \\
\text { about } 3,918 \mathrm{ft} \text { (example, S1/2 sec. } 29 \text {, T. } 17 \text { N., R. } \\
30 \mathrm{E} \text {.), also stone artifacts (manos, metates, point } \\
\text { chips, and others) at several open archaeological } \\
\text { sites, which rest on lake sediments of second lake } \\
\text { unit and encrusted with tufa of the third lake unit, } \\
\text { as low as } 3,910 \mathrm{ft} \text { altitude; (c) vicinity of Stillwater } \\
\text { Slough (eolian sand as low as 3,910 ft); (d) eastern } \\
\text { Stillwater quadrangle west of Stillwater Lakes } \\
\text { (eolian sand as low as 3,880 ft). Section } 49 \text { (table } \\
\text { 10) illustrates this unit. Locally the unit is } \\
\text { represented by a disconformity, recording weak } \\
\text { eolian erosion and small-scale gullying (for example, } \\
\text { along Wildcat scarp); the L-Drain soil is approxi- } \\
\text { mately coeval. }\end{array}$ \\
\hline & 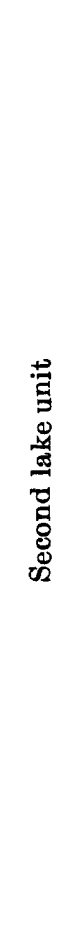 & $\begin{array}{l}\text { Second youngest lacustrine } \\
\text { tongue of Fallon forma- } \\
\text { tion: lake sand, silt, clay, } \\
\text { minor amounts of gravel } \\
\text { and tufa; also coeval al- } \\
\text { luvial sand; intermediate } \\
\text { in age between first and } \\
\text { second interlake units. } \\
\text { Type locality: Flat south- } \\
\text { west of Eetza Mountain } \\
\text { (northwest of Turupah } \\
\text { Flat), SW1/4 sec. } 29, \mathrm{~N} 1 / 2 \\
\text { sec. 32, NW1/4 sec. 33, T. } \\
18 \mathrm{~N} \text {. R. } 30 \mathrm{E} \text {. Lake sand } \\
\text { and silt of the unit are here } \\
\text { prominent. }\end{array}$ & $\begin{array}{l}\text { Second Fallon lake. Maxi- } \\
\text { mum altitude about } 3,930 \\
\mathrm{ft} \text {; recessional stillstand } \\
\text { at about } 3,927 \mathrm{ft} \text {. See } \\
\text { text for river history. }\end{array}$ & 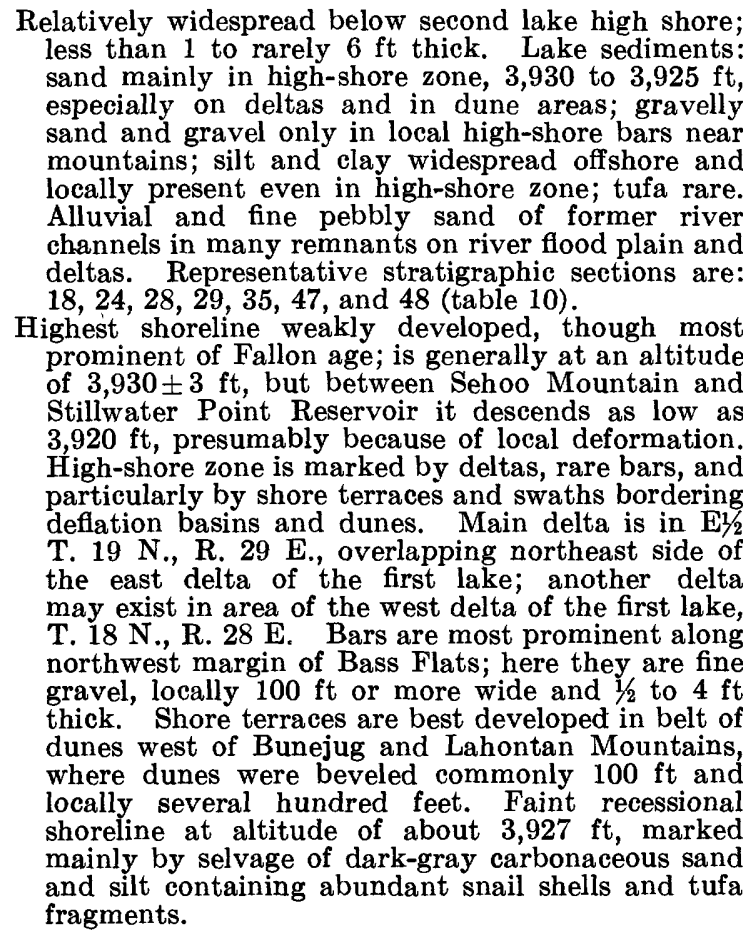 \\
\hline & 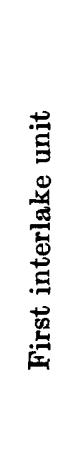 & $\begin{array}{l}\text { Oldest interlacustrine tongue } \\
\text { of Fallon formation, inter- } \\
\text { mediate in age between } \\
\text { first and second lake units; } \\
\text { eolian sand and alluvium. } \\
\text { Type locality: Flat between } \\
\text { Eetza Mountain and Still- } \\
\text { water Slough, mainly sec. } \\
20, T \text {. } 18 \text { N., } \mathrm{R} \text {. } 30 \text {. } \\
\text { Unit here is eolian sand, } \\
\text { locally between lake sands } \\
\text { of first and second lake } \\
\text { units. }\end{array}$ & $\begin{array}{l}\text { First Fallon lake recession, } \\
\text { to at least as low as } \\
\text { altitude of } 3,900 \mathrm{ft} \text {. }\end{array}$ & $\begin{array}{l}\text { Rare, differentiated only where overlain by second } \\
\text { lake unit; less than } 1 \text { to rarely } 4 \mathrm{ft} \text { thick; locally } \\
\text { absent and represented by disconformity. Folian } \\
\text { sand occurs locally in dune belt west of Bunejug } \\
\text { and Lahontan Mountains, along scarp of Sagouspe } \\
\text { fault zone, and elsewhere in Stillwater and Soda } \\
\text { Lake quadrangles to at least as low as } 3,900 \mathrm{ft} \text {; } \\
\text { mostly fine-medium sand, some fine and some } \\
\text { medium sand, practically no coarse sand and grit. } \\
\text { Alluvial sand and fine-pebbly sand, in former } \\
\text { Carson River channels, locally exposed in canals } \\
\text { in northwest Carson Lake quadrangle, as low as } \\
\text { about } 3,910 \mathrm{ft.} \text { A little alluvial sand and silt at } \\
\text { Bass Flats in gullies older than the modern ones, as } \\
\text { low as } 3,915 \mathrm{ft} \text {. Stratigraphic sections illustrating } \\
\text { this unit are: } 22 \mathrm{~b}, 25 \text {, and } 48 \text { (table 10). }\end{array}$ \\
\hline
\end{tabular}


TABLE 7.-Subdivisions of the Fallon formation-Continued

\begin{tabular}{|c|c|c|c|c|}
\hline $\begin{array}{c}\text { Mem- } \\
\text { ber }\end{array}$ & Unit & Definition and type locality & Lake history recorded & Sediments and shore features \\
\hline 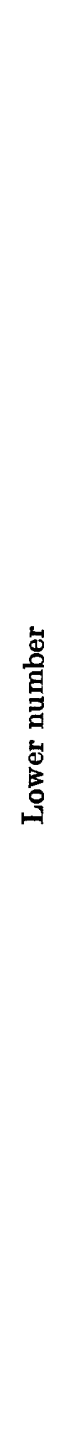 & 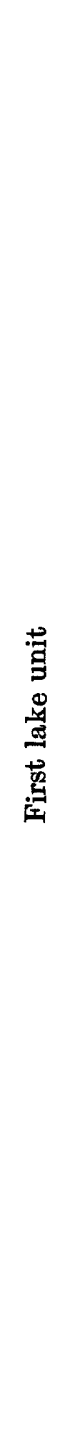 & $\begin{array}{l}\text { Lacustrine tongue in lowest } \\
\text { part of Fallon formation, } \\
\text { directly overlying Toyeh } \\
\text { soil: lake sand, silt, clay, } \\
\text { and minor lake gravel, } \\
\text { tufa, and volcanic ash; also } \\
\text { coeval alluvial sand. } \\
\text { Type locality: North side of } \\
\text { Turupah Flat, secs. } 29,33 \text {, } \\
34 \text {, and } 35, T \text {, } 18 \text {., R. } 30 \\
\mathrm{E} . \text { at altitude of about } \\
3,948 \mathrm{ft.} \mathrm{Lake} \mathrm{sand} \mathrm{of} \mathrm{the} \\
\text { unit here overlies eolian } \\
\text { sand of Turupah forma- } \\
\text { tion and clay of Sehoo } \\
\text { formation and is overlain } \\
\text { by eolian sand of Fallon } \\
\text { formation. }\end{array}$ & $\begin{array}{l}\text { First and highest Fallon } \\
\text { lake, maximum altitude } \\
\text { about } 3,948 \mathrm{ft} .\end{array}$ & 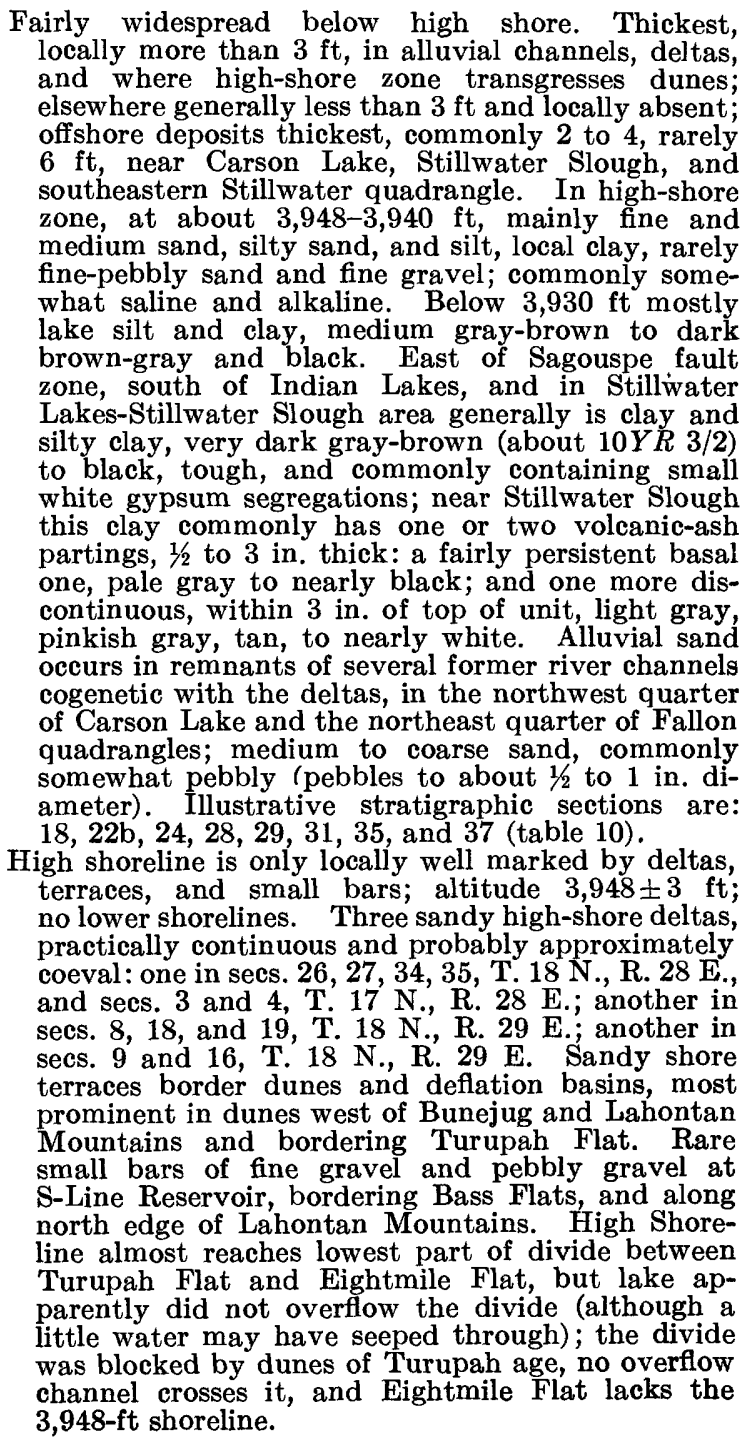 \\
\hline
\end{tabular}

In the highlands the chief deposits are in the saddles where sands of the Sehoo and Wyemaha formations are extensively exposed and into which the wind is funnelled. The higher mountains in the map area generally are free of this sand, but a few miles to the south they are extensively inundated by it, as at the Blowsand Mountains.

Morphology.-Eolian sand of even the older parts of the Fallon formation is so young that original morphologic features are largely preserved. Dunes and other features have remained constant in type and orientation and have migrated only locally. Sand drifts characterize areas of moderate deposition, and dunes those of strong deposition. Dunes are best developed-albeit discontinuously-in the Carson Desert proper west of the Stillwater Lakes and the farming area; they also border Bass Flats, Eightmile Flat, and the west side of Turupah Flat. In these areas the dunes are commonly 20 to 30 feet high and rarely as much as 50 feet high. In the highlands sand drifts prevail; well-developed dunes occur only locally in pass areas of maximum sand transport, such as Simpson Pass Wyemaha Valley, and the pass between Rainbow Mountain and the Stillwater Range. 
Each of the three main classes of dunes is present (Smith, 1946, 1953) : phytogenic, psammogenic, and windshadow.

Phytogenic dunes, formed where the desert-shrub vegetation has controlled the trapping of sand, are by far the most prevalent. These include U-shaped, V-shaped, Y-shaped, parabolic, and most longitudinal dunes. They form where wind directions vary through an appreciable arc, and are oriented in the resultant direction, the open end of the $\mathbf{U}$ facing into the wind (the opposite of barchans); they are essentially nonmigratory. Variants range from broad forms (parabolic dunes) to narrow ones that are much elongated in the resultant wind direction (longitudinal dunes). This is the sole class of dunes in most of the interior of the Carson Desert proper, where presentday winds vary through at least $200^{\circ}$ of arc, from north-northeast to south-southeast. Here they are predominantly longitudinal dunes; their subparallel ridges, oriented N. $70^{\circ}-85^{\circ} \mathrm{E}$. (mostly N. $75^{\circ}-82^{\circ} \mathrm{E}$.), are dominant landscape features, commonly extending unbroken for 1 mile, and rarely several miles. That these dunes have been virtually fixed in their present positions for several thousand years is shown by shorelines and shore deposits of the older Fallon lakes against them, wherever they are at the altitudes of the high levels of these lakes.

Psammogenic dunes develop when sand surfaces themselves trap more sand, and include barchans and transverse dunes. Such dunes are migratory and characterize the few belts of most active eolian sand transport and deposition, notably the 2-mile-wide belt along the south edge of Carson Sink east of the Carson River. Here the dune axes are oriented N. $80^{\circ}$ E., the resultant wind direction.

Windshadow dunes occur locally where sand is trapped by natural declivities. In the lowlands these typically are the lee slopes of fault scarps, deflation basins, stream valleys, and hills. Steep windwardfacing slopes locally have trapped some eolian sand (for example, at Rattlesnake Hill and Wildcat scarp west of the Bunejug Mountains).

At the edges of the lowlands and in the highlands the dune axes commonly diverge from the prevailing east-northeast orientation in the interior of the Carson Desert due to orographic deflection of wind currents.

Lithology.-This eolian sand is mostly fine and finemedium sand but locally, in the lowlands, contains considerable medium and coarse sand and even some grit ( $1 / 2$ to 1 mile southeast of Salt Wells, Battleground Point, and elsewhere along the south border of Carson Sink). Mechanical analyses of typical coarse occurrences show two distinct maximums, one in the fine or fine-medium sand size and the other in the coarse sand and grit size. Fragments of clay from the Sehoo formation are locally incorporated in small proportions; true clay dunes (lunettes) are absent. Very rarely the sand consists of ostracode shells of the family Cyprididae, which make up drifts a few inches high in the lee of wind-eroded ostracode-bearing clay of the Sehoo formation (Russell, 1889, p. 289). Crossbedding is characteristic in the lowlands, owing to dune development, but commonly is absent in the highlands. The sand is cemented locally by calcium carbonate or other salts, either deposited by efflorescence along the shores of the lakes of Fallon time, or from mineralized ground water (as on the northeast slope of Simpson Pass).

Wind erosion features.-The deflation basins and plains inherited from Turupah time were further deflated in Fallon time, but the distribution of Fallon lake and eolian sediments within and about these features shows that the younger deflation was minor compared with the older. Yardangs and ventifacts of Fallon age occur locally, mostly in the western lowlands, where wind erosion of unconsolidated sediments has been especially severe.

Strongly deflated areas commonly have local deposits of lag gravel, but true desert pavement is rare in the lowlands owing to the scarcity of gravel. Generally most or all of the lag gravel is tufa. This lag gravel is the residue after wind removal of fine overlying sediments, and differs from that associated with the stronger soils such as the Toyeh and Churchill soils; the latter type originated from soil-forming processes and invariably overlies a vesicular soil horizon.

\section{ALLUVIUM}

Alluvium of the Fallon formation is of two types, very different in occurrence and lithology: alluvium of the highland washes, which occurs largely in the highlands and is mainly gravel and sand; and alluvium of the Carson River, which is restricted to the lowlands and is mainly sand and silt.

Allurial gravel and sand of the highland washes.Alluvial gravel and sand of the Fallon formation underlies the post-Lake Lahontan channels, flood plains, and alluvial fans of the highland washes. In the mountains and higher parts of the piedmonts these washes are incised 10 to 30 feet, locally 60 feet, below the final terraces of Lake Lahontan, and have narrow flood plains. The incised reaches die out downward near an altitude of 4,100 feet, and the washes have built small alluvial fans where they debouch upon the lower piedmont slopes. Washes draining the Stillwater, Cocoon, Desert, 
and Dead Camel Mountains have the largest post-Lake Lahontan fans.

The alluvium of highland washes resembles that of late Sehoo-Indian Lakes age in the Indian Lakes formation (p. 71), except that the former typically is somewhat finer. From geomorphic and stratigraphic relations, it can be subdivided locally into lower and upper parts, that may be roughly correlative with the lower and upper members of the Fallon. In general, the lower part is thicker, somewhat coarser, and extends farther from the mountains than the upper part. The most recent deposits have few large boulders. Drift sand has locally encroached upon the earlier wash channels, partly or entirely blocking them (for example, in the saddle between the Stillwater Range and Rainbow Mountain, in the Simpson Pass area, and along Diamond Field Jack Wash south of Bass Flats).

Alluvial sand and silt of the Carson River (Recent flood plain).-Alluvium of the Fallon formation deposited by the Carson River forms the Recent flood plain. This alluvium is largely silt and some interbedded clay and fine sand interlaced with narrow stringers of sand and pebbly sand that represent bed deposits in former channels of the river. It has the intricate structure and heterogeneous lithology characteristic of such deposits. The main channel fillings near Fallon are 100 to 400 feet wide, 10 to 20 feet thick, and mostly pebbly coarse to medium sand, having pebbles commonly half an inch and rarely 1 inch in diameter. Several miles farther downstream the main channels have mostly medium sand and some coarse sand containing a few pebbles, mostly under $1 / 4$ inch and rarely $1 / 2$ inch in diameter. The pebbles are granitic and gneissic rocks from the Sierra Nevada and volcanic rocks from this and other highlands. Low natural levees border the channels in places. The channel sands commonly can be traced downstream into deltaic sediments of particular lakes of Fallon age. Most of the exposed interchannel alluvium is in the upper member of the Fallon formation. This alluvium is the most fertile of the basin-interior deposits and underlies most of the farmland.

Above the apex of the west delta of the late Sehoo lake in sec. 30 , T. 19 N., R. 28 E., the Recent flood plain of the Carson River lies in a valley half a mile wide trenched 100 feet below the top of the middle Sehoo delta at Lahontan Dam and 20 feet below this surface 9 miles airline below the dam. Five miles west of Fallon the flood plain is only 10 to 15 feet below the west late Sehoo delta, and here it starts to fan out through an arc of nearly $120^{\circ}$ along a series of former channels (pl. 11).

The broadened flood plain below the entrenched section is in two parts. The main, southern, part lies south of Rattlesnake Hill, and is shaped like a broad ragged fan; it extends southeastward and eastward toward Carson Lake and Stillwater Slough, and eastward and northeast ward beyond Rattlesnake Hill to the Stillwater Lakes. The other part lies along the present course of the river northward to Carson Sink and is relatively narrow and extremely irregular. In places in the southern part, small erosional remnants of older deposits rise above the modern flood plain. The depth of dissection below the tops of these remnants decreases downstream, from about 10 feet at an altitude of 3,970 feet, about 4 feet at 3,950 feet, to none below 3,920 feet.

The northern extension of the flood plain is 0.1 to 1.2 miles wide and is entrenched 12 to 15 feet below the surface of the west delta of the late Sehoo lake as far downstream as the main Sagouspe scarp. Below this scarp it widens to more than 1 mile in a reach graded to a small high-shore delta of the third Fallon lake at an altitude of about 3,915 feet. Farther downstream the flood plain spreads even more widely, commonly 2 miles or more, in areas interlaced through dunes of Turupah and Fallon age and erosional remnants of Sehoo formation. The alluvium exposed here is of late Fallon age and is aggraded to deltas at altitudes of about $3,905,3,885$, and $3,875-3,880$ feet; the lowest is at the mouth of the river on the south edge of Carson Sink.

\section{COLLUVIUM}

Colluvium of the Fallon formation is far too thin and local to be mapped. It is mostly slope-wash mantle, derived by reworking of older creep mantle. Prominent among the deposits are torrent levees along rill channels on steep slopes; these levees consist of jumbles of blocks 1 or 2 feet, locally 5 feet or more, thick. Layers of slope wash are interbedded with loess and midden deposits in Hidden Cave (section 39, table 10) and other caves.

\section{LAKE SFDIMENTS AND SHORE FEATURES}

General features.-The lake sediments of the Fallon formation consist of sand, silt, and clay, and minor amounts of gravel, tufa, and volcanic ash. They are much thinner and more restricted in distribution than those of the Lahontan Valley group, and shore features associated with them are much less conspicuous. The Fallon lakes were relatively shallow ( 20 to 85 feet maximum depth), small, and fleeting, having only feeble wave action and longshore drift. The deposits and shore features along the highest shoreline of each lake are most conspicuous; transgressive and regressive shorelines are little in evidence. Each lake was shallower than its predecessor, so these high shores form a concentric series, the younger shorelines inside the 
older ones; also the lake deposits and shore features are successively thinner and weaker. Even the older stronger shorelines can be identified only locally by mappable deposits or definite landforms (pls. 2, 11 and table 7). In only a few places are these older shorelines deformed by faulting and warping.

Deltas of the Carson River.-The Carson River built a series of deltas on the west sides of the Fallon lakes; they were generally graded to the high shores. The deltas range in gradient from 5 feet per mile east of Fallon to less than 1 foot per mile in the lowest parts of the basin; they do not have recognizable topset, foreset, and bottomset beds. The highest shorelines generally are poorly marked and the subaerial parts of the deltas grade imperceptibly into the sublacustrine parts. Sublacustrine distributary channels commonly are prominent, in some cases extending 1 mile or more from the shoreline (pl. 11). Typically they are very low ridges (whereas subaerial channels generally lie slightly below the flood plain) and have widened, blunted ends.

The deltaic sediments are the most distinctive and thickest shore deposits. They are mostly lake sand associated with some silt and clay, and contain alluvial sand in distributary channels. They are heterogeneous in lithology and structure yet monotonous in general aspect, having few marker horizons. The distributary channels are mainly fine-gravelly coarse-to-medium sand at the lake margins, grading to fine and medium sand offshore; commonly their sublacustrine parts have natural levees of finer sand, grading outward to fine sand, silt, and local clay in interchannel areas.

Other shore deposits and features.-Away from the deltas the shore deposits and shore features generally are so subdued that close study is needed to identify them. Only the highest shorelines can be identified, with one or two exceptions. Shore sediments are mostly medium and fine sand, commonly quite silty, locally silt and clay, and rarely (near the mountains) gravelly sand and fine gravel. Carbonized plant matter, mostly from tules, cattails, and other aquatic plants, and contemporaneously deposited tufa in small nodules or thin coatings occur locally.

Typical shore features are shore swaths (veneers of reworked or newly introduced sand or sandy silt), shore terraces against dunes or scarps of unconsolidated sediment, and rare tiny bars and spits. The swaths range in width from a few feet to several hundred feet, the terraces from a few feet to 50 feet, and the bars from 20 to 100 feet, being generally only 2 or 3 feet, rarely 5 feet, high. The older lakes built thicker shore deposits and carved more conspicuous shore features than the younger ones. Shores are smooth and unembayed in some areas but commonly are very irregular, even crenulate, particularly where the lakes flooded dune areas. The shores of the younger lakes generally are the most irregular, for they lie more in dune areas and are least smoothed out by shore erosion (figs. 33, 34).

Offshore deposits.-Offshore sediments of individual lake units are thin discontinuous beds of silt, silty clay, and clay in light to dark shades of tan-gray, gray-tan, brown, and black. Their prevailing tan or brown tint distinguishes them from clay of the Sehoo formation, which generally is greenish gray. They are commonly 2 to 4 feet thick on deltas, but elsewhere range from a knife edge to rarely more than 1 or 2 feet in thickness. The Carson Lake and Stillwater Lakes areas were perennial sumps, and in their lower parts the Fallon formation is almost entirely lake sediments, several feet to locally more than 10 feet thick.

Although Carson Sink is now the lowest part of the basin, it contains almost no lake sediments of Fallon age except_at the mouth of the Carson River. This probably is because the river rarely drained directly to the sink during Fallon time; also, any lake sediments that were deposited tended to be removed by deflation.

\section{FOSSILS}

First Fallon lake time.-Four mollusk collections from lake sediments of the first Fallon Lake unit, determined by Joseph P. E. Morrison, U.S. Geological Survey, contained the species listed in table 6. All these species are aquatic and are still living in the Lake Lahontan region.

The "32-inch midden" layer in Hidden Cave (unit 5 in section 39 , table 10 ), probably correlative with the first Fallon lake unit, yielded plant, mammal, and bird fossils. Most of this material probably was brought in by Indians living in the cave. The mammal bones were identified by S. B. Benson and staff, Museum of Vertebrate Zoology, University of California, Berkeley, who found the bones of one man (Homo sapiens) and the following:

Odocoileus hemionus (blacktail or mule deer, 1 individual) Marmota flaviventer (yellow-bellied marmot, 1 individual) Neotoma sp. (wood rat, 1 individual)

Lepus californicus (black-tailed jackrabbit, 2 individuals)

Sylvilagus sp. (cottontail or pigmy rabbit, 1 individual)

The plant remains from this bed, identified by $\mathrm{H}$. L. Mason, Annetta Carter, H. K. Sharsmith, Isabel Tavares, and Calen Smith, Department of Botany, University of California, Berkeley, included the following in approximate order of abundance :

Scirpus sp. (tule, predominant)

Typha sp. (cattail)

Eleocharis sp. or Juncus sp. (rush)

Phragmites sp. (cane) 

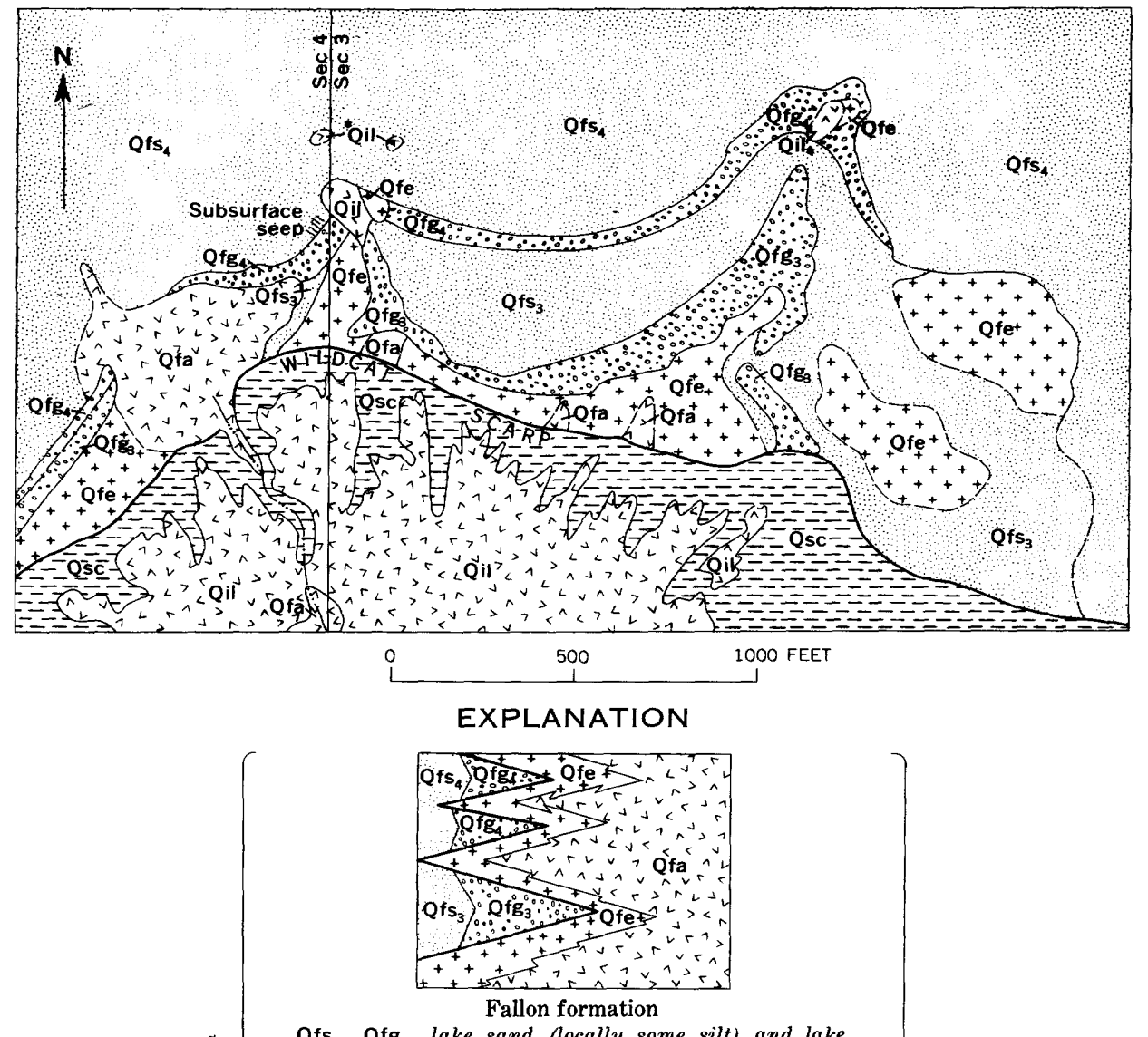

$\mathrm{Qfs}_{4}$, $\mathrm{Qfg}_{4}$, lake sand (locally some silt) and lake gravel (fine gravel to pebbly sand), of the young lake and interlake unit; both locally underlain and (or) overlain by eolian sand of this unit. Gravel unit is highshore deposit of fourth and fifth Fallon lakes and the type for the young lake and interlake unit. $\mathrm{Qfs}_{3}, \mathrm{Qfg}_{3}$, lake sand and gravel fine gravel to pebbly sand), respectively, of the third lake unit; locally underlain and overlain by eolian sand of second interlake and younger age. Gravel unit is high-shore deposit of third Fallon lake and the type for the third lake unit.

Qfa, alluvial gravel, sand, and silt, mostly of late Fallon age.

Qfe, eolian sand of middle and late Fallon age; locally some intercalated lake sand

$$
\text { DISCONFORMITY }
$$

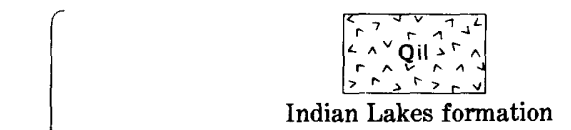

Alluvial gravel of late Sehoo-Indian Lakes age. ${ }^{*}$ Asterisk indicates patches of coarse gravel, probably of this age, that have been let down by erosion of underlying sediments because of retreat of Wildcat Scarp DISCONFORMITY

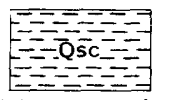

Sehoo formation

Lake clay and silt, some sand, of the dendritic and
lower members

\section{Contact}

Dashed where approximately located

FIGURE 33.-Geologic map of the type locality of the third lake unit, and of the young lake and interlake unit, of the Fallon formation, along Wildcat scarp north of White Throne Mountains, secs. 3 and 4, T. 16 N., R. $29 \mathrm{E}$. 

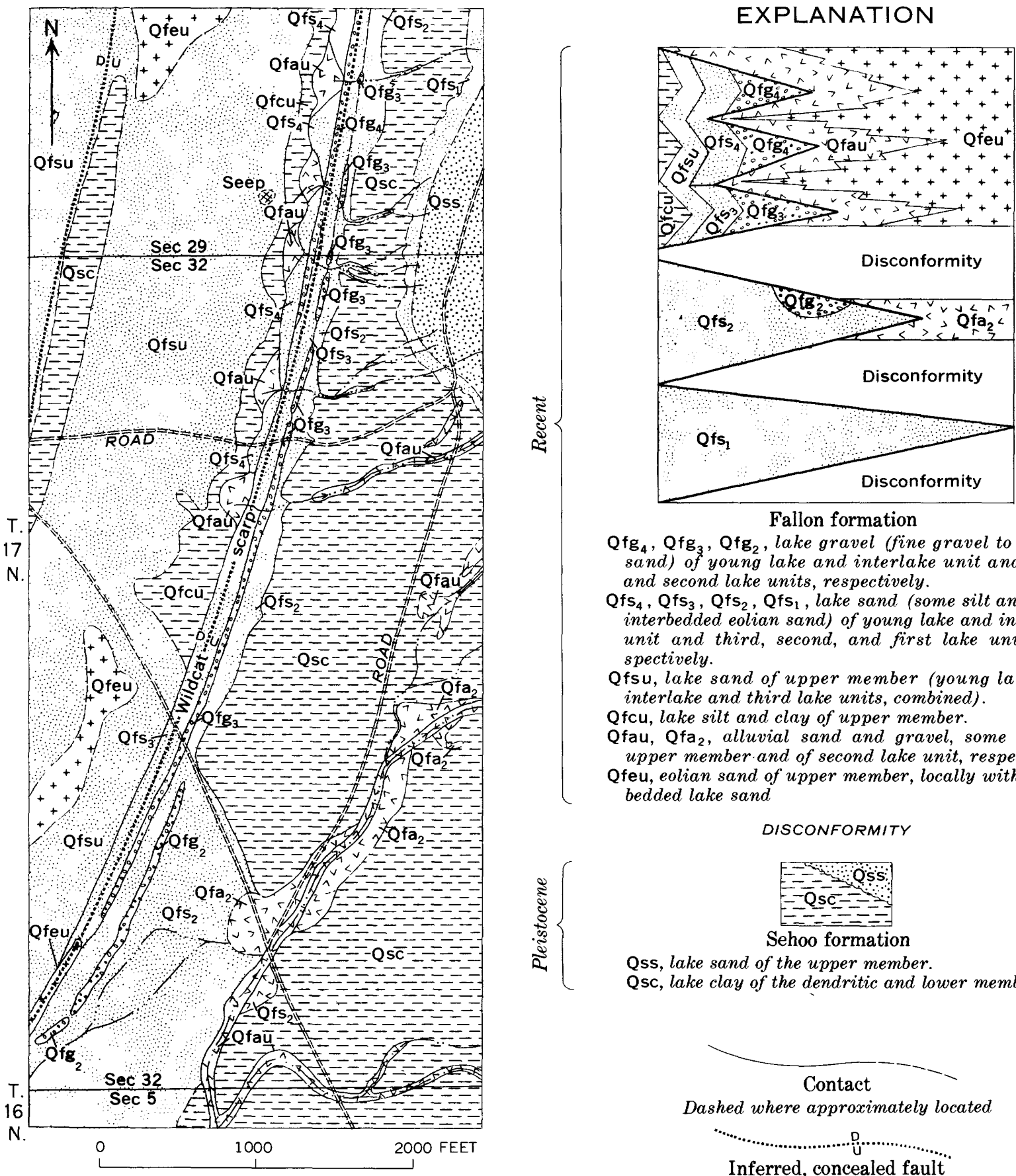

EXPLANATION

Fallon formation

$\mathrm{Qfg}_{4}, \mathrm{Qfg}_{3}, \mathrm{Qfg}_{2}$, lake gravel (fine gravel to pebbly sand) of young lake and interlake unit and third and second lake units, respectively.

$\mathrm{Qfs}_{4}, \mathrm{Qfs} \mathrm{s}_{3}, \mathrm{Qfs} \mathrm{s}_{2}, \mathrm{Qfs} \mathrm{s}_{1}$, lake sand (some silt and local interbedded eolian sand) of young lake and interlake unit and third, second, and first lake units, respectively.

$\mathrm{Qfsu}$ lake sand of upper member (young lake and interlake and third lake units, combined).

Qfcu, lake silt and clay of upper member.

Qfau, $\mathrm{Ofa}_{2}$, alluvial sand and gravel, some silt, of upper member and of second lake unit, respectively. Qfeu, eolian sand of upper member, locally with interbedded lake sand

DISCONFORMITY

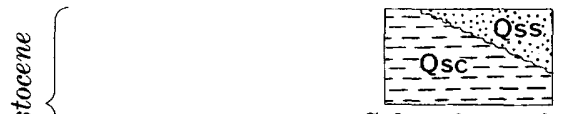

Sehoo formation

Qss, lake sand of the upper member.

Qsc, lake clay of the dendritic and lower members

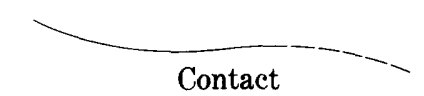

Dashed where approximately located

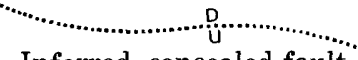

Inferred, concealed fault

$\mathrm{U}$, upthrown side; $\mathrm{D}$, downthrown side

Figdne 34.-Geologic map showing relations of various units of the Fallon formation along Wildcat scarp southwest of Bunejug Mountains, sec. 29 and 32 , T. 17 N., and sec. 5 , T. 16 N., R. $30 \mathrm{E}$. 
Oryzopsis hymenoides (ricegrass)

Panicum capillare (witehgrass)

Elymus triticoides (seeds, in pack-rat cache)

Apocynum sp. (dogbane)

Populus sp. (cottonwood)

Artemisia sp. (sagebrush)

Sarcobatus sp. (greasewood)

Salix sp. (willow)

Mussel shells, probably Anodonta californiensis, are common.

Second Fallon lake time.-Six mollusk collections from lake sediments of the second lake unit, determined by Joseph P. E. Morrison, U.S. Geological Survey, contained the clams and snails listed in table 6. These species are all aquatic and are all still living in the lake Lahontan region, except possibly Cincinnatia cf. $C$. integra.

The top midden layer in Hidden Cave (unit 2 in section 39 table 10), probably correlative with the second Fallon lake unit, yielded bones of the following vertebrates, also identified by S. B. Benson and staff, University of California:

Ursa sp. (black or grizzly bear, 1 individual ; and artifact) Ovis canadensis (mountain sheep, several individuals) Lepus californicus (black-tailed jackrabbit, 6 individuals) Taxidea taxus (badger, 1 individual)

odocoileus hemionus (blacktail or mule deer, 1 individual) Vulpes macrotis (kit fox, 1 individual)

Marmota faviventer (yellow-bellied marmot, 1 individual) Citellus sp. (ground squirrel, 2 individuals)

Peromyscus sp. (whitefooted mouse, 1 individual)

Bird bones, identified by Hildegarde Howard, Los Angeles County Museum, Los Angeles, Calif., included:

Futica sp. (coot, number of individuals unknown, identified from artifacts only)

Aechmorphorus occidentalis (western grebe, 1 individual) Duck, unidentified ( 1 individual)

This midden contains many fresh-water mussel shells, probably Anodonta californiensis; it also yielded snake and lizard vertebrae, both unidentified, and insect wings, probably Cybister sp. Plant remains from this layer, identified by H. L. Mason and staff, University of California, Berkeley, included (in aproximate order of abundance) :

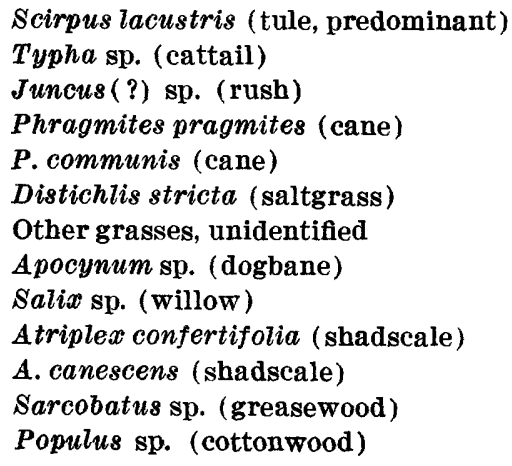

\section{Artemisia sp. (sagebrush)}

Urtica sp. (nettle)

Asclepias sp. (milkweed)

Third Fallon lake time.-Five mollusk collections from lake sediments of the third lake unit were determined by Joseph P. E. Morrison, U.S. Geological Survey, as containing the species listed in table 6. All these species are aquatic and are still living in the Lake Lahontan region. The pelecypod Anodonta californiensis is particularly abundant along the high shore of the third Fallon lake in the Carson Lake area.

Late Fallon time.-Mollusk shells tend to be concentrated mostly along the high-shore zones of the fourth and fifth Fallon lakes but in places are distributed over the lake bottom. They are mostly concentrated in isolated groups of similar individuals. In order of decreasing abundance they are: Helisoma tenue californiense, fusiform gastropods, Anodonta californiensis, and Sphaerium nobile. Nineteen collections of mollusks from the young lake and interlake unit, including three from modern sediments, were determined by Joseph P. E. Morrison, U.S. Geological Survey, as the species listed in table 6. All the species are aquatic, and all still live in the Lake Lahontan region, except Armiger crista and Lymnaea stagnalis. Both these holarctic species indicate northern relations of their fauna. This is the southernmost record, Recent or Pleistocene, of Armiger crista in North America. It is living from Alaska to Wyoming to northern Indiana to Maine.

Two collections of fish bones, from shores of the fourth and fifth Fallon lakes, respectively, near the south margin of Carson Sink, were identified by D. H. Dunkle, U.S. National Museum, as a salmonoid fish, either Rhabdofario sp. or Salmo sp.

\section{SOILS OF FALLON AGE GENERAL FEATURES}

The older sediments of the Fallon formation bear weak, though distinct, soils. Generally the soils are relicts, recording all soil development from the time the sediment was laid down to the present; buried soils are comparatively rare.

In the relict soils, the profile development increases with age, being greatest on the first lake unit and nil in modern sediments. The increase is not regular, however; it is barely perceptible between the first and second lake units, but obvious between the second and third lake units. Soil development was thus most active during the second interlake interval. The soil formed during this interval is called the L-Drain soil; it is the only soil of Fallon age well enough developed to merit formal designation.

The soils of Fallon age are so weak that differences 
in development due to different local environmentsparent material, drainage, slope, and salinity-commonly are greater than differences due to age. These soils therefore do not especially aid in subdividing and correlating the parts of the formation.

\section{L-DRAIN SOII}

The L-Drain soil is of middle Fallon age, approximately coeval with the second interlake unit. On preFallon deposits it is masked by the stronger Toyeh soil except where that soil was eroded prior to middle Fallon time. Normally it is a very weakly developed Gray Desert soil, but in poorly drained saline locations it grades to a very weakly developed Solonchak soil.

The type locality is the site of soil profile $36 \mathrm{~S}$ (table 11 ), in the drainage canal known as the " $L$ " Drain, just west of the northwest corner of the Fallon Auxiliary Naval Air Station (as of 1950), where the soil is relict upon alluvial sand in a distributary channel in the delta of the first Fallon lake (fig. 35).

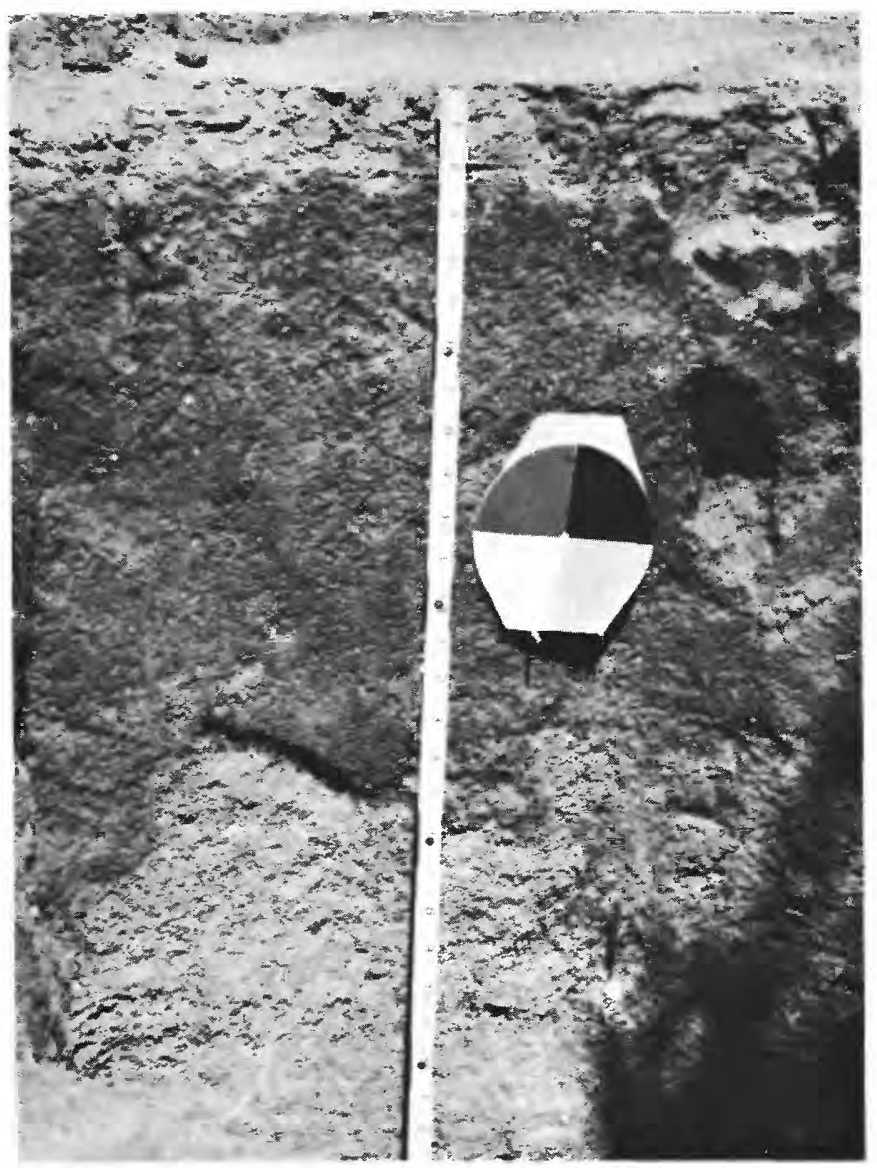

Figure 35.-L-Drain soil, developed on alluvial sand (channel sand of the Carson River) of first lake unit of Fallon formation. Top $2 \pm$ inches is vesicular horizon, next $15+$ inches is oxide and calcareous horizons (boundary between oxide and calcareous horizons is gradational and invisible in picture). Type locality for this soll, NW $1 / 4$ sec. 16, T. 18 N., R. 29 E., 3,946 feet altitude, see soil profile section $36 \mathrm{~S}$.

$695-3830-64-7$
The profile of the L-Drain soil is weak compared with the Toyeh soil, but stronger than in soil of late Fallon age.

The upper 2 to 3 inches of the profile in the Gray Desert facies is an incipiently developed vesicular horizon, which is light gray (about $10 Y R$ 7/2) and has weak vesicular to weak granular and locally faint to weak coarse columnar structure. Texture varies from loamy sand to fine sandy loam to silt, and consistence generally is slightly hard. The base of the horizon generally is abrupt, but less so than that of the Toyeh soil. This horizon is absent in the Solonchak facies.

This soil lacks true oxide and calcareous horizons, though very slight oxide illuviation in the upper part and very slight calcium carbonate accumulation in the lower part are locally evident. The main evidence of soil development is color change. The soil is brown to grayish brown $(10 Y R 5 / 3$ to $5 / 2)$ to a depth of 10 to 16 inches, and grades through a diffuse irregular boundary into lighter colored parent material. Structure is weak coarse granular to single grain, and consistence is slightly hard to soft and nearly loose.

\section{SOIL OF LATE FALLON AGE}

Relict soil on the third lake unit of the Fallon formation is characterized by slightly more brownish color than the parent material, and also by slight induration and development of a very weakly granular structure to depths of 8 inches to 1 foot. Soil horizons are not even weakly differentiated. Soil development on the young lake and interlake unit is not discernible.

\section{STRUCTURAL FEATURES OF LAHONTAN VALLEY AND FALLON AGE}

\section{GENERAL RELATIONS}

Intermittent small-scale high-angle faulting has continued to the present. This late deformation has been largely in the basins; the high shorelines of the Eetza, early Sehoo, and middle Sehoo lakes seem devoid of significant faulting or warping anywhere in the map area.

The faults at the periphery of the basins generally parallel the local margin and many, like the Wildcat fault zone (p. 91), are conspicuously arcuate. The faults in the interior of the Carson Desert strike northwest through north to northeast. Some interior faults limit grabens, which are bounded on the other side by peripheral faults. Many of the larger faults are in fault zone (p. 91), are conspicuously arcuate. The to a few feet, rarely more than 20 feet, but several fault zones extend 3 to 12 miles. The fault traces are rarely exposed, being generally buried by younger deposits. The larger and more recent faults have prominent 
LAKE LAHONTAN: GEOLOGY, CARSON DESERT, NEV.

scarps, but even these generally are much modified by later erosion and sedimentation. The faults are shown by scarps, dislocated shorelines, abrupt changes in altitude of beds, and springs and seeps (including deposits of spring sinter and tufa). Most of these features generally are better seen on aerial photographs than on the ground.

The more important faults active in Lahontan Valley and Fallon time are discussed below. Magnetometer and well data suggest that many, particularly the marginal faults, may be associated with larger buried faults of post-Bunejug pre-Paiute age.

\section{PRE-SEHOO FAULTS}

Three pre-Sehoo faults are exposed in the Carson Lake quadrangle: two in a gravel pit southwest of BM 3949 at the northwest prong of the Bunejug Mountains, and another on the ridge $21 / 4$ miles south of the same bench mark. The third is exposed in the gravel pit shown in the southeast corner of the Fallon quadrangle. All are vertical faults of a few feet displacement that cut the Eetza formation but not the overlying Sehoo; all are downthrown on the basin sides.

There is indirect evidence of pre-Sehoo faulting in several places along the margins of Salt Wells Basin. On the pediment east of the Bunejug Mountains and north of the Cocoon Mountains are many siliceoussinter-cemented remnants of eolian sand of the Wyemaha formation (fig. 12B), generally alined with faults in the bedrock of the pediment. The opal cement was deposited from water rising along the faults, but the orifices became closed during Sehoo time and the springs now are extinct. On the west margin of Fourmile Flat, 2 miles north and immediately east of the southeast corner of the Carson Lake quadrangle, eolian sand of the Wyemaha lodged against a steep scarp that probably was due to pre-Sehoo faulting. This scarp has been accentuated by minor post-Sehoo faulting.

Considerable faulting took place in Wyemaha time near Upsal Hogback. Only the more important faults are mapped, and generally the displacement of their exposed parts followed the volcanism; notable is the probable horst extending several miles southward from Upsal Hogback (later buried by Sehoo formation, then partly exhumed by deflation in Turupah time).

\section{POST-SEHOO FAULTS}

\section{WIUDCAT FAULT ZONE}

The Wildcat fault zone is by far the largest of the marginal faults at the south edge of the Carson Desert. It extends about 12 miles in a great arc around the south and east sides of Carson Lake, changing about $325^{\circ}$ in strike from about N. $45^{\circ} \mathrm{W}$. in its west end (north of the Desert Mountains), to about due west along the north edge of the White Throne Mountains, and through east to north along the west side of the Bunejug Mountains, to about N. $10^{\circ} \mathrm{W}$. at its northeast end. It is named from the Wildcat freight station of pioneer days, south of Carson Lake. A prominent scarp, named Wildcat scarp, which is mainly of the Sehoo formation, marks the zone; it ranges in height from several feet at either end to 35 feet in its central part. The scarp rises abruptly from the nearly level Carson Lake plain, which has a drop of only 6 to 10 feet in the $1 / 2$ to 2 miles from the scarp to the present shore of Carson Lake. Detailed mapping of the Fallon and older units along the scarp (shown partly in fig. 36 and pl. 12) indicates that shore erosion by the Fallon lakes did not initially form the scarp-it merely caused some modification and retreat of the scarp secondarily after faulting. The stratigraphy of the Fallon formation at Bass Flats and along the scarp northwest of these flats reveals two principal episodes of post-Sehoo faulting, during the first and second Fallon interlake intervals, respectively. The faults are nowhere exposed, but several are inferred from springs and seeps, from local evidence of displacement of Sehoo formation, from exposures of this formation on both sides of the faults, and from local secondary scarps (demonstrably not caused by shore erosion). For example, the easternmost fault near the north end of the main mass of Bunejug Mountains displaces the Sehoo about 5 feet down on the west. Some of these faults lie close to the main scarp, others a quarter of a mile or more basinward from it. More exact differentiation of these faults and their displacements must await better subsurface data.

\section{OTHER MARGINAL FAULTS}

On the piedmonts north of the Desert Mountains and east of the Dead Camel Mountains is a series of en echelon arcuate marginal faults that is essentially a widened continuation of the Wildcat fault zone. These faults partly control the long badland escarpment east of the Dead Camel Mountains (though this escarpment is mainly erosional, probably by deflation). PostSehoo displacements range from a few inches to a few feet, and only the faults having the most displacement are mapped. Generally the basin sides are downdropped, but locally the mountain sides are.

Post-Sehoo marginal faults are especially numerous in Salt Wells Basin. An east-west fault on the piedmont north of Turupah Flat, near Salt Wells, is inferred from a deposit of siliceous sinter, evidently deposited about the orifice of an extinct artesian spring, cementing sand and gravel of the Sehoo formation. On 
the east edge of Eightmile Flat are two large and several small northwestward-trending faults that displace the Sehoo and Wyemaha formations 1 foot to several feet. These faults seem to mainly antedate the extensive deflation of this flat in Turupah time, but they were sites of minor surface breakage during the July 6 , 1954, earthquake. The low ridge separating Eightmile and Turupah Flats is a horst defined by several small northward- and northeastward-trending faults. On the west side of Eightmile Flat are at least a dozen very small faults of similar trend that displace the Sehoo. Many of them are fissurelike cracks of only a few inches displacement, of which only the largest were mapped; several saline seeps issue from the larger ones. At the south margin of Eightmile Flat is a west-northwestward-trending fault zone containing two main faults that have been traced for $31 / 2$ miles. They have a total displacement of about 25 feet, down on the basin side; their scarps are almost completely mantled by eolian sand. Rock Springs may issue from a buried fault in this zone. This fault zone intersects at a right angle with a northward-trending zone at the west margin of Fourmile Flat. The overall pattern of the faulting shows that the entire Eightmile Flat-Fourmile Flat area was downfaulted in post-Sehoo time, Eightmile Flat was tilted slightly to the southeast, and Fourmile Flat was the most depressed, particularly the salt flat in its central part.

\section{SAGOUSPE FAULT ZONE}

The Sagouspe fault zone is the largest of the postSehoo faults in the interior of the Carson Desert. It is named from the Sagouspe diversion dam and canal, and is marked by a scarp 12 to 30 feet high and about 8 miles long, extending $\mathrm{N}$. of $40^{\circ} \mathrm{W}$. to within about $31 / 2$ miles of Upsal Hogback. The faults are generally concealed by younger eolian sand and lake sediments, but some are poorly exposed on the clay flat at the north end of the zone. The most detailed information, however, has come from the Sagouspe irrigation canal, 1 mile east-northeast of Sagouspe Dam. Three of the faults are exposed in the canal bed and two others have been located by boreholes; several are downdropped a few feet on the northeast, the others on the southwest, defining two small grabens and two horsts (fig. 36 shows four of the faults in the southwestern part of the zone). The main displacement seems to be by one or more inferred faults on the northeast edge of the zone, effecting at least 10 feet net displacement that is down on the northeast. All the faults seem to be of the same age; they postdate the early lithoid tufa of the upper member of the Sehoo formation and predate the lake sand of this member, which filled the fault grabens. Evidently the late Sehoo lake was barely at this level, however, and the Carson River was flowing approximately its present course, because the sand contains many small pebbles similar to those in the bed of the Carson River today. Probably the river was temporarily diverted into the grabens, filling them with sediment.

To the southeast this fault zone passes beneath the Carson River flood plain but it is known to extend at least into sec. 25 , T. 19 N., R. 29 E., associated with small-scale grabens and horsts as at the Sagouspe canal,

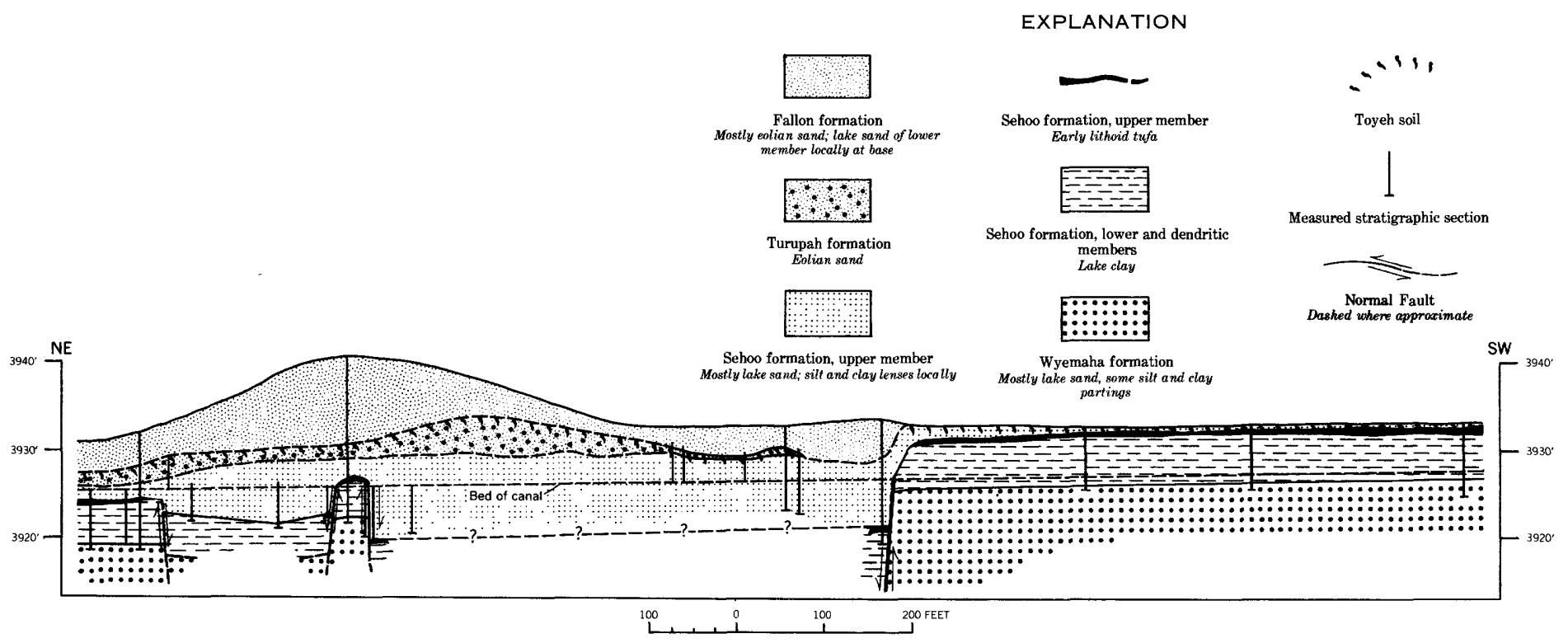

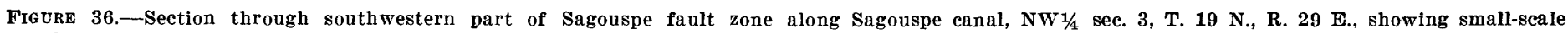

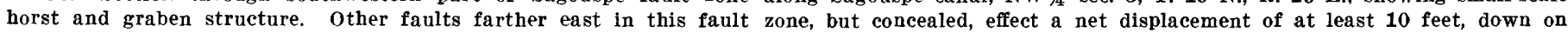
the northeast, for the whole zone.

$695-3830-64-8$ 
from boreholes and local exposures of Sehoo formation in a drainage canal and in erosion remnants.

\section{OTHER INTERIOR FAULTS}

Post-Sehoo faults seem to be especially numerous in the Stillwater Lakes area. The subdued topography of this area consists of many low ridges and basins having 5 to 15 feet of relief, which trend mainly N. $20^{\circ}-45^{\circ} \mathrm{E}$., and, subordinately, approximately transverse to this trend. The basins are mostly lakes, ponds, or marshes. This topography is believed to reflect many small horsts and grabens which are due to post-Sehoo faulting; the whole area is virtually a foundered graben. The predominant trend of the topography is about $60^{\circ}$ from that of deflation basins and sand dunes in the interior of the Carson Desert, so it could not have been carved by wind. Auger holes locally have proved offsets of strata along the low scarps, but the fault patterns are complex. The northwest side of this foundered graben is vaguely defined by discontinuous scarps, several feet to about 6 feet high, of $\mathrm{N} .30^{\circ} \mathrm{W}$. to N. $60^{\circ} \mathrm{E}$. individual trend, alined in a zone trending N. $20^{\circ} \mathrm{E}$. from near Stillwater almost to Carson Sink. Only the two most definite of the concealed faults suggested by these scarps are mapped. Here exposures and boreholes show that clay of the Sehoo has been downthrown several feet on the east; traverses with an airborne magnetometer also showed a magnetic anomaly at the northern scarp. Another fault zone limits the graben on the southeast, mainly east of the map area. Extensive surface breakage from the earthquake of Aug. 23, 1954, followed this zone and one small concealed fault in it is mapped just east of Freeman Pond.

The Stillwater Lakes fault zone seems to extend southwestward into the Carson Lake area, although the young sediments in this part of the basin have concealed most evidence of faulting. Buried faults, trending mainly northeast, are suggested by local seeps, a subdued northeastward-trending topographic linearity, several low scarps within 1 or 2 miles of either side of Stillwater Slough, and small faults and numerous large cracks developed by the earthquakes of JulyAugust 1954. The northwest edge of this zone seems to follow approximately the 3,940-foot contour line southeast of Fallon, passing several miles north of Carson Lake. That the Carson Lake area itself has been downfaulted or downwarped in post-Sehoo time is suggested by the abrupt thickening of post-Sehoo sediments near the lake and by downward displacement of the clay of the Sehoo formation.
At the south margin of Carson Sink a low scarp trending N. $50^{\circ}$ W., from secs. 10 to 13 , T. 21 N., R. 29 E., marks a probable concealed fault. Several boreholes northeast of the scarp suggest that the WyemahaSehoo contact is displaced a few feet down on the northeast. Other northwest-trending faults may underlie the dune complexes at Battleground (the peninsula just east of the river mouth) and at the next peninsula to the east, for extensive seepage zones, possibly fed by water rising along faults, border the northeast sides of those peninsulas.

A low scarp on the flood plain southwest of Fallon indicates another concealed fault of Fallon age, trending north from sec. 34 to sec. 15, T. 18 N., R. 28 E. The scarp is mantled by eolian sand of the Fallon formation, and is downdropped on the east; and considerable seepage, probably artesian, issues along its base.

\section{DISPLACEMENT OF SHORELINES}

The post-Sehoo faulting has caused almost no discernible displacement of shorelines. The larger faults of this age are all basinward from the high shore of the late Sehoo lake, except north and northeast of the Lahontan Mountains, along the badland escarpment east of the Dead Camel Mountains, and on the Carson River delta where this shoreline generally is obscure or eroded by deflation. These faults also either predate or do not transect the high shorelines of Fallon age, except north and northeast of the Lahontan Mountains.

In the trough northeast and east of Rainbow Mountain the middle and late Sehoo high shorelines are downdropped about 15 feet. The high shorelines of the first and possibly the second Fallon lakes also may be downdropped several feet here, but these shorelines are poorly marked. North of the Lahontan Mountains the high shoreline of the first Fallon lake appears undeformed, but that of the second Fallon lake, $1 / 2$ to 2 miles farther basinward, is tilted, from an altitude of about 3,930 feet north of Eetza Mountain to about 3,920 feet north of Rainbow Mountain. No faults associated with the tilting have been identified.

\section{POSSIBLE EXPLOSION CRATERS OF LATE FALLON AGE NEAR STILLWATER LAKES}

Northwest of Stillwater Lakes, in the $W_{1}^{1} / 2$ sec. $29, \mathbf{T}$. 21 N., R. 31 E., are two connected basins arranged like the southwest and northwest quadrants of a circle, the northeast one almost circular and 800 feet in diameter, and the southwest one elongate, 2,000 feet long and 1,000 feet wide. Both have 10 - to 25 -foot rims of clay of the Sehoo, capped by lake sediments of the Fallon forma- 
tion and flat floors of lake silt of the upper member of the Fallon. The Sehoo formation commonly has a slight outward dip. Volcanic rock ejecta are absent, but the basins are believed to be craters resulting from a small volcanic or gaseous explosion, not only because of their peculiar form and orientation (unlike the deflation basins in the area), but also because a light-colored bed of ashy silt (presumed to be explosion debris) in the young lake and interlake unit of the Fallon formation (table 7) thickens toward them, and attains its greatest thickness, more than 2 feet, at the west edge of the southwest basin.

\section{EARTHQUAKES IN HISTORIC TIME}

Strong earthquake shocks were felt in the southern part of the Carson Desert in 1873, 1916, and 1932, and minor ones in 1930 and 1949, but the epicenters of these quakes were outside the map area. These shocks opened many earthquake cracks in restricted areas of the Carson Desert, particularly on the flat north of Wildcat scarp and in the southern part of Carson Sink near the mouth of the Carson River (fig. 37).

Several earthquakes that had epicenters in the map area occurred in July and August 1954. On July 6 two heavy rolling shocks occurred, 11 hours apart, separated and followed by minor tremors. The first shock was at $3: 13$ a.m., Pacific standard time, and had an epicenter (provisional) at lat $39^{\circ} 23^{\prime} \mathrm{N}$., long $118^{\circ} 32^{\prime} \mathrm{W}$. (Perry Byerly, Director of Seismological Stations, University of California, Berkeley, written communication, July 22,1954 ) ; its intensity rating (estimated, modified Mercalli Intensity Scale of 1931) was IX at the epi-

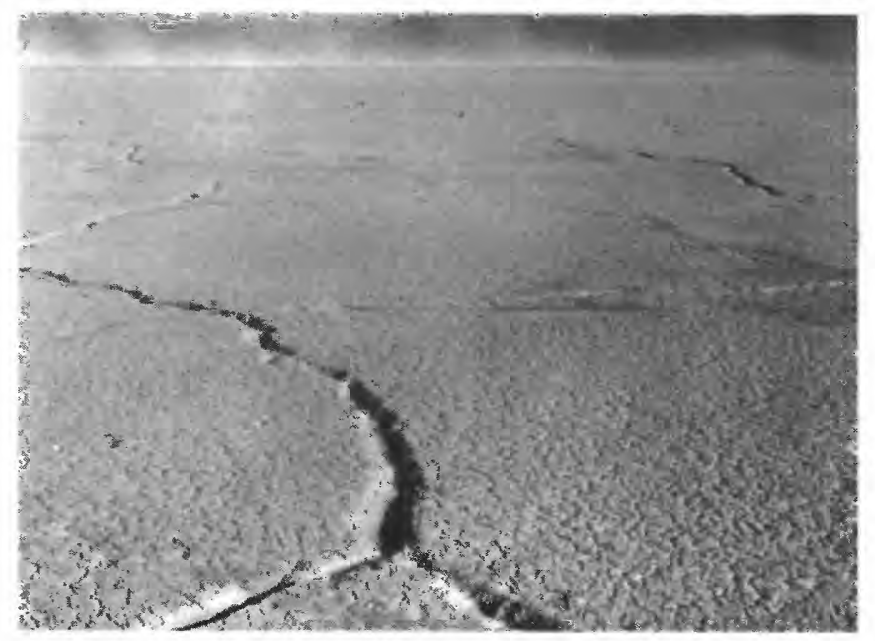

Figure 37.- Polygonal earthquake cracks in southern Carson Sink Such cracks occur locally in clay of Sehoo formation east of the mouth of the Carson River. Two generations can be seen. The younger (fresher) was formed by tremors from the earthquake of January 1949, whose epicenter was near Verdi, Nev. Largest crack in foreground is about 8 inches wide. Sec. 33, T. 22 N., R. 30 E. center and VII to VIII in the Carson Desert-Lovelock area (Cloud, 1956, p. 34, 35, 38) ; magnitude on the Gutenberg-Richter scale was reported to be 6.8 by the Seismological Laboratory at Pasadena (Cloud, 1956, p. 38) and $63 / 4$ by the Berkeley station (Seismological Soc. America, 1954); felt area was about 130,000 square miles (Cloud, 1956, p. 38). The second main shock occurred at $2: 08$ p.m., P.s.t., had about the same epicenter, and was reported as magnitude $63 / 4$ by Pasadena and $61 / 4-61 / 2$ by Berkeley. The principal aftershocks occurred on July 8 (2 shocks: magnitudes 5, Pasadena, and 51/2, Berkeley), July 9 (magnitude 4.7, Pasadena), July 30 (magnitude 51/4, Pasadena; 43/4, Berkley), and August 2 (magnitude 51/4-51/2, Pasadena; $51 / 4$, Berkeley). (Data from Seismological Soc. America, 1954.)

The July 6 earthquakes and aftershocks produced surface breakage about 11 miles long and N. $12^{\circ}$ E. in average trend, from U.S. Highway $50,11 / 2$ miles east of Salt Wells, thence along the east side of Rainbow Mountain, thence across the flats to the north, ending at the north side of Stillwater Point Reservoir (Tocher, 1956). The breakage occurred either in a single line or as a linear zone of breaks. For about a third of the total length of the fault it showed as severe cracking and no apparent displacement, but along the remainder it formed a vertical scarp 1 to 12 inches high. The west side went up relative to the east side, except in a secondary fault in the northern part of Rainbow Mountain where the west side went down 1 to 2 inches; movement was entirely dip slip. The faulting along Rainbow Mountain apparently followed earlier faults in the bedrock, partly those separating the basalt and dacite of Rainbow Mountain and the Truckee formation, and partly within the Truckee formation. Descriptions of the ground breakage, property damage, intensity distribution and strong-motion seismograph results for these quakes and those of August 23, 1954, have been published by Tocher (1956), Steinbrugge and Moran (1956), and Cloud (1956). The greatest concentration of severe damage to buildings, canals, and paved highways in the Carson Desert proper is in a northeastward-trending zone about 6 miles wide that passes through Stillwater, thence about half way between Fallon and the north edge of Carson Lake, to the Lone Tree School (Tocher, 1956). This damage probably was due largely to heaving and lurching because of unstable layers in the Quaternary fill of this area; nevertheless the linear distribution coincides with the southward extension of the Stillwater Lakes fault zone (p. 94) and might be due to minor reactivation of this zone by the quakes. A geologist who checked ground 
disturbance in the area between and after the two main shocks of July 6 (Norman Silberling, oral communication, 1956) noted that most of the ground-disturbance features in the Stillwater-Lone Tree zone originated with the first shock, but damage to U.S. Highway 50 east of Salt Wells did not develop until the second shock. Epicenter data are too generalized to show whether the epicenter of the first shock was actually in the Stillwater-Lone Tree zone and that of the second along the east side of Rainbow Mountain, but this is a possibility.

Another strong earthquake having about the same epicenter occurred on August 23, 1954, at $9: 51$ p.m., P.s.t. It was rated as the same magnitude as the first July 6 shock (6.8 on the Gutenberg-Richter scale) and was given the same maximum-intensity rating, IX. Felt area was 150,000 square miles. Surface breakage lay mainly north of that of the July 6 quake; from the north shore of Stillwater Point Reservoir into the alkali flats southeast of Carson Sink-about 12 miles-having an average trend of N. $12^{\circ} \mathrm{E}$.; some fresh dislocations also took place in the northern part of the zone of breakage of the July 6 quake. The breakage was as beforepartly a single crack and partly roughly parallel cracks in a zone as much as 1 mile wide; vertical displacements as great as 18 inches were entirely dip slip, and the west side invariably was uplifted relative to the east side. Property damage was slightly less severe than from the July 6 shock, and in general was similar. Again the greatest concentration of damage occurred in the Stillwater-Lone Tree zone, and commonly in the same places affected by the first earthquake.

According to the Fallon Eagle of August 25, 1954, several seismologists believed that the epicenter of this series of shocks was shallow, about 10 to 15 miles below the surface; however, V. P. Gianella (written communication, July 22, 1954) believes that the nature of the aftershocks indicated that the epicenter was deep seated.

\section{GEOLOGIC HISTORY}

\section{TERTIARY HISTORY}

The oldest rocks exposed, the basalt and dacite of Rainbow Mountain, attest first to basaltic and andesitic volcanism, possibly beginning in pre-Miocene time, accompanied by pervasive high-angle shearing and lowgrade hydrothermal alteration, and then, after the most intense shearing, to deposition of several hundred feet of dacitic lava. After an unknown time interval, several hundred feet of rhyolitic to dacitic lava - the Eagles House rhyolite - was deposited near Eagles House, in the White Throne Mountains, and in the northeastern Desert Mountains.
Beginning during the later part of the rhyolitic volcanism, probably in early Pliocene time, the Truckee formation was deposited. Its paleogeography is little known but the western part of the Great Basin probably was then at least two or three thousand feet lower than now, the local relief may have been less and some areas probably still drained to the ocean (Axelrod, 1950 , p. 238-268; V. P. Gianella, oral communication, 1948). The fossil flora and fauna show that the climate was semiarid temperate (Axelrod, 1950; Chaney, 1938; Nolan, 1943, p. 169), having changed from the warm wet climate of the early Miocene because of moderate uplift of the Sierra Nevada. It now is known that the sediments were laid down in several basins, which were separate to varying degrees, rather than in a single huge basin as King (1878) thought. The distribution of lithofacies suggests that the basins were roughly congruent with many of the present basins, but commonly somewhat broader. (For example, most of the highlands adjoining the southern Carson Desert were covered with Truckee sediments.) The basins probably were locally deepened by faulting during Truckee time, but deformation seems to have been subdued and erosion and sedimentation dominant during that time. The present Carson Desert probably received especially thick deposits.

Some volcanic activity continued, however, for the highly tuffaceous sediments attest to considerable contemporaneous volcanism. The large amount of pumice in the White Throne Mountains probably came from a nearby explosive center. Its dominantly stream-laid character suggests that the pumice was erupted in small increments over a rather long interval, giving streams ample opportunity to rework it. Minor coeval more mafic volcanic activity is indicated by a few andesitic and basaltic ejecta at several horizons in the Truckee in the White Throne Mountains and by local mafic tuff in the Stillwater Range.

As Truckee time progressed, drainage became better integrated and the basins of deposition were gradually enlarged by deposition and perhaps by capture. In middle and late Truckee time the enlarged basins had local lake-filled depressions in which sand, silt, clay, and locally considerable diatomite and limestone were deposited. The flora attest to a moderately warm semiarid climate (Axelrod, 1950, p. 241-243), and the fact that the lake clay commonly is saline and gypsiferous suggests semiaridity.

Mafic volcanism, possibly coeval with and (or) following the later Truckee, occurred locally, depositing as much as 400 feet of mainly andesitic and basaltic lava-the lower part of the Bunejug formation-nota- 
bly in the Bunejug and Cocoon Mountains. Contemporaneously much high-angle normal faulting took place. This faulting created new highlands and basins and the general outlines of the present topography began to be defined, although the local relief was slight. Some highlands were uplifted relatively early and much eroded before the Bunejug formation was deposited, so that in places a marked angular unconformity separates the Truckee and Bunejug. In the White Throne Mountains an erosion surface of several hundred feet of local relief was developed. In the interior of the Carson Desert sedimentation may have proceeded continuously from Truckee into Paiute and later time.

In late Bunejug time, probably late Pliocene though perhaps earliest Pleistocene, the eruptions changed to flows of olivine basalt of fairly constant composition. Fissures were the principal vents, although many pipelike vents also were active. Faulting seems to have largely died down, for the later lava flows are generally conformable throughout and rarely display intradepositional faulting. These flows were somewhat more extensive than the earlier ones; although thinner, they commonly inundated surfaces having several hundred feet of local relief, filling in the depressions and forming extensive lava fields. Some of the higher highlands without vents were never covered, however, or were only thinly covered (namely the southeastern White Throne Mountains and northeastern Lahontan Mountains).

\section{QUATERNARY FISTORY}

\section{PRE-LAKE LAHONTAN HISTORY}

Only a vague outline of the earlier Quaternary history is known because post-Bunejug pre-Paiute basin sediments are not exposed; some information has come from gross geomorphic features preserved in the highlands, from geophysical data, and from logs of the few wells that penetrate the deeper fill. This is supplemented by reconnaisance observations, including those of the writer, on deposits and landforms outside the map area.

Biogeographic evidence suggests that in late Pliocene and early Pleistocene time the valleys of the Great Basin lay close to sea level (Deevey, 1949, p. 1397-1398; Miller, 1946, p. 43; Hubbs and Miller, 1948, p. 26). Drainage probably was well integrated and possibly the Carson Desert area drained to the ocean. A postmature erosion surface of several hundred feet local relief formed in the highlands during the interval following the Bunejug volcanism and before the active faulting of post-Bunejug-Paiute time.

Succeeding this interval of relative structural and volcanic quiescence, the Sierra Nevada-Great Basin re- gion was uplifted. This uplift probably started in the early Pleistocene, and by late middle Pleistocene time the Great Basin had risen 3,000 to 5,000 feet to about its present average altitude (Blackwelder, 1934b, p. 561-562; Ferguson, Muller, and Cathcart, 1953, 1954).

Major block faulting accompanied the uplift. The principal displacements occurred during two climaxes of faulting that were separated and followed by intervals of relative structural quiescence. This faulting is inferred to have further defined and uplifted blocks that previously tended to be highlands and to have further depressed the basins. It controlled the major outlines and differential elevation of the main topographic units seen today in the area-the Carson Desert itself, the side basins, and the mountain groups-lowering the basins several thousand to locally about 4,000 feet relative to adjoining mountains. Together, the two climaxes constituted the last principal period of basinand-range deformation. At the close of the second climax the relief between mountains and basins was greater than now, for in later Quaternary time erosion and sedimentation outstripped the declining basin-andrange deformation, so that the mountains were progressively more and more worn down and the basins filled in with sediment.

During these climaxes most of the faults visible today were active, for many old faults were reactivated and new ones created. Both climaxes were characterized by high-angle normal faulting which trended mainly northeast to northwest; tilting and folding were minor or absent. The principal displacement was at the boundaries between the present highlands and basins, where horst mountains and graben basins were formed, although the interiors of both highlands and basins also were much faulted in places.

Both climaxes of basin-and-range deformation initiated intervals of accelerated erosion in the highlands and deposition in the basins. The subdued post-Bunejug topography in the highlands quickly became dissected following the first climax. During the relatively quiescent interval between the two climaxes, the mountain valleys developed to early and middle maturity and pediments formed. After the second climax the lower parts of the mountain valleys were deepened. Subsequent alluviation has largely buried the pediments.

During the first climax, drainage to the sea was interrupted and the intermontane basins probably developed internal drainage. As this climax waned drainage tended to become reintegrated, only to be again disrupted during the second climax. Since the later climax, integration has gone on steadily, but at varying rates. It probably was most rapid during preLake Lahontan pluvial intervals. Basin capture prob- 
ably occurred both by normal stream capture and by corrasion through divides by overflow of pre-Lake Lahontan Quaternary lakes. The interbasin canyons along the middle reaches of the principal rivers of the Lake Lahontan basin probably originated, either in this way or by superposition on early Pleistocene sediments, during one or more pluvial intervals that followed the second climax of faulting. Chief among these canyons are: Emigrant Canyon of the Humboldt River, above Golconda, Nev.; the canyon of the Truckee River between Washoe Meadows and Wadsworth; the canyon of the Carson River between Dayton and Carson Valley; Wilson Canyon, of the West Fork of the Walker River, between Mason and Smith Valleys; and Churchill Narrows (an abandoned channel of the Walker River between Mason Valley and the valley of the Carson River, near Weeks, Nev.). All these canyons probably formed at about the same time, because they now are in about the same part of the mature stage of erosion. They are clearly younger than the last climax of basin-and-range deformation, yet they were in existence long before Lake Lahontan because most of them contain alluvium, colluvium, and soil of pre-Lake Lahontan age and several, such as Emigrant Canyon and the Truckee River canyon, contain sediments of Lake Lahontan.

Evidence of a pre-Lake Lahontan lake.-A single exposure of shore sediment at about 4,020 feet (p. 23) records a pre-Lake Lahontan Quaternary lake, probably of pre-Paiute age. The maximum level of this lake is not known but is not likely to have been much higher, for the bedrock floors of pre-Paiute Quaternary canyons along the middle courses of the Truckee, Carson, and Humboldt Rivers were graded to a base level at least this low. The lake may have been fully as deep as Lake Lahontan, nevertheless, because the Carson Desert was not as deeply alluviated as now and its floor probably lay several hundred feet lower.

Thick zones of clay penetrated by wells in the deeper basin-interior fill suggest long-lasting pre-Lake Lahontan Quaternary lakes, but cannot be correlated with exposed deposits.

Paiute time.-In later pre-Lake Lahontan Quaternary time the Paiute formation was deposited. Paiute time was characterized by marked alluviation and colluviation in the highlands, and presumably by considerable valley erosion in the mountains. Alluvial fans were built that are much larger and thicker than any subsequent ones, and the lithology of their gravel shows that the highland washes, though ephemeral, had torrential floods at least as big as the largest in Lake Lahontan time. The colluvial mantle in the mountains, also much thicker than any younger colluvium, attests to stronger solifluction, creep, and slope wash than subsequently. ${ }^{2}$ Eolian deposition seems to have been negligible. Sedimentation conditions in the basin interior are unknown, for sediments coeval with the Paiute are here deeply buried.

The strong alluviation and colluviation suggest a climate at least as cold and wet as that during the lake maximums of Lake Lahontan. Perhaps the bulk of the Paiute was deposited during a pre-Lake Lahontan pluvial period such as that which is coeval with the Sherwin glaciation of Blackwelder (1931) in the Sierra Nevada; if so, a predecessor of Lake Lahontan probably also existed, but evidence for it has not been found in the Carson Desert. The youngest part of the Paiute, however, probably dates from the earlier part of the last interpluvial interval before the advent of Lake Lahontan (the later part of this interval probably is represented by the Cocoon soil):

Paiute time seems to have been a time of relative structural stability; at least no faults definitely of this age are known. Basaltic eruptions, of this age or earlier, took place at Rattlesnake Hill, yielding minor flows and ending with minor explosions that left the vent choked with agglomerate.

Cocoon interval.- The Cocoon interval, when the Cocoon soil formed, was a time of comparative balance between erosion and deposition in the highlands, when chemical weathering exceeded erosion. The relatively intense weathering, manifest especially by the clay content and reddish-brown color of the oxide horizon of this soil, suggests that the climate was considerably warmer than now. Precipitation also must have been higher than now, for strong soil formation could not have taken place under the intense aridity that otherwise would have prevailed under the higher temperature. The strong calcareous horizon, however, is typical of soils formed in semiarid rather than subhumid climates. Thus, the Cocoon soil probably formed under a semiarid climate somewhat warmer and wetter than now-probably the later part of the interpluvial interval preceding Lake Lahontan. Evidence is lacking on sedimentation and lake conditions in the inner Carson Desert, for here the zone that represents this soil is deeply buried.

\footnotetext{
2 Intensified mass wasting during pre-Lake Lahontan Quaternary time seems to have been the main cause of the generally rounded forms and scarcity of rock outcrops that characterize the mountains of the region. Knopf $(\mathbf{1 9 2 4}$, p. 42$)$ commented on the more active solifiuction on north slopes compared to south slopes, due to greater insolation on north slopes, as a possible explanation of the fact that the north slopes of valleys in this region tend to be long and relatively gentle and the south slopes short and steep.
} 


\section{HISTORY OF LAKE LAHONTAN} EETZA TIME

Lake-depositional history.-After development of the Cocoon soil came a long interval of deep-lake conditions - the first part of Lake Lahontan time-during which the Eetza formation was deposited. This formation and coeval shore features record two lake maximums. The earlier, at an altitude of about 4,380 feet, was the highest level ever attained by Lake Labontan. This level is 515 feet above Carson Sink today, but the lake was at least 200 feet deeper at the time of the maximum because the basin floor has been raised by subsequent sedimentation. At this level, Lake Lahontan inundated about 8,540 square miles and extended about 250 miles north and south and 185 miles east and west, without overflowing its basin. The second maximum was only 40 feet lower. Between the two maximums the level of the lake dropped at least 320 feet, but the recession seems to have been brief judging from the scanty recessional deposits.

On the highland shores mainly boulder and cobble gravel, some pebble gravel, and minor lithoid tufa were deposited, but almost no sand. The tufa was precipitated by mats of algae growing within a few feet below and above water level. Lake-bottom sedimentation history is unknown because the bottom sediments are rarely exposed.

Eetza time was the stormiest part of Lahontan time. The shore gravels and morphologic features attest to waves stronger than those of any later lakes at all levels, from highest to lowest. The smaller details of the preexisting topography were severely modified by carving of prominent shore terraces and cliffs, accompanied by construction of correspondingly large gravel terraces, bars, and spits. On shores most exposed to waves, boulders, commonly several feet in diameter, were dislodged and transported, and terraces 50 to locally 200 feet wide were cut in hard lava rocks. Ten main shorelines were formed, as well as more than a dozen moderate to weak ones (pl. 9). The strongest waves (and hence the most severe windstorms) date from the first Eetza transgression as suggested by the fact that the lower part of the lake gravel generally is the coarsest and is associated with the most strongly developed shore features.

Distribution and orientation of Eetza shore deposits and morphologic features show that strong winds came from all directions except east, but mainly from the north, northwest, and southwest; northwest winds predominated. Winds from the south and southwest were much more prominent than during Sehoo time. For instance, while the lake was comparatively low, large spits were built northward from the northwest and northeast prongs of the Bunejug Mountains. Other large spits and bars were built just below the Lahontan beach. At Russell Spit (p. 64), for example, longshore drift was both from the south and northwest in Eetza time, but northwest drift was predominant. In order for drift from the south to occur here, winds must have blown from due south to southeast; southwesterly winds were blocked by the Desert Mountains. Similar wind conditions apparently prevailed at intermediate lake levels, as shown at many places in the highlands.

History above the lake shores.-After formation of the Cocoon soil, apparently early in Eetza time the highland washes locally dissected a few feet into alluvial gravel of the Paiute along their middle courses. This was followed by a few feet of gravel fill as the lake rose; the fill was graded to the higher lake shores but was far too scanty to produce deltas. The Carson River built a delta, but the exposed part lies west of the map area.

At the same time small amounts of colluvium were deposited on the mountain slopes, mainly by solifluction and creep which reworked the oxide horizon of the Cocoon soil. The small volume of alluvium and colluvium from the highlands attests to relatively minor erosion of these areas during Eetza time; erosion was practically negligible compared with that in pre-Lake Lahontan Quaternary time.

Soil development was negligible, the only evidence of it being an incipient weathering profile dating from the middle-Eetza recession.

\section{WYEMAHA TIME}

A relatively long interval, when the Carson Desert was completely or nearly dry and when the Wyemaha formation was deposited, followed the recession of the second Eetza lake. Early and middle Wyemaha time was characterized by deposition of vast quantities of eolian sand, which virtually drowned some areas in the basin interior and the lower mountain passes. Deflation and transport of the sand were favored by sparse vegetal cover and severe windstorms. The volume of this sand is far too great for it to have been derived locally; it must have come from outside the area, probably from extensive sandy outwash plains and deltas in Carson, Lower Carson, Smith, and Mason Valleys. Sand was blown from these areas in great belts, 40 to 75 miles long and a dozen or so miles wide, trending generally northeast and east-northeast across mountains and basins. The greatest concentration of the sand near the Carson Desert is just south of the map area in the north half of the Allen Springs quadrangle. The highland washes flowed much less than now, for al- 
luvium of this age is very scanty and many of the canyons were deeply choked with eolian sand.

These features bespeak extreme aridity. Conditions probably fluctuated, however, for the thickness and character of the Wyemaha where it is penetrated by wells in the basin interior suggest considerable alluviation by the Carson River and intermittent inundation by shallow lakes. During much of Wyemaha time the river probably rarely reached the Carson Desert; the lowest sumps were playas; and deposition of eolian sand and deflation of fine sediment were dominant processes in the basin interior.

Explosive eruptions at Upsal Hogback deposited basaltic tuff and tuff breccia in the vicinity; these eruptions had virtually ceased by late Wyemaha time.

Late Wyemaha time was characterized by increased alluviation in the highlands, apparently from augmented local runoff that was due to increased precipitation during a probably short interval before the protective vegetal cover that characterized the Churchill interval became established. The alluvium was generally sandy owing to reworking of the ubiquitous blanket of eolian sand. Its scantiness and lithology, together with the absence of soil development, suggest, however, that precipitation still was relatively low and characterized by infrequent torrential rains. The Carson River probably also brought more sediment to the Carson Desert.

The close of Wyemaha time is placed arbitrarily at the start of the Churchill interval, which is an essentially time-parallel boundary. In the highlands this boundary is at the top of the youngest alluvium and eolian sand of the Wyemaha, for here sedimentation seems to have practically ceased while the Churchill soil was forming. In the inner lowlands, however, deposition of sediments that are referred to the Wyemaha continued through Churchill time; this final episode of Wyemaha sedimentation is discussed in the following section.

\section{CHURCHILL INTERVAL}

The Churchill interval, recorded by the Churchill soil, was another time of reduced erosion; the eolian sand became stablized and deposition of alluvium largely ceased in the highlands. Although the climate may have been less windy, the main factor in stabilization probably was development of plant cover, probably mostly grasses. Shrubs also seem to have been present, however, as evidenced by calcium carbonate concentrations surrounding their deeply penetrating roots below the calcareous horizon of the soil. Probably the plant cover was more dense during this interval than during any other part of Lahontan Valley and Recent time.
The accelerated rate of soil development and the somewhat reddish color and moderate clay content of the oxide horizon suggest that the temperature was higher than now. The strong total profile development and strong development of the calcareous horizon of the soil, well-developed plant cover, and lakes in the lowlands all attest to semiarid rather than arid climate. Precipitation must have been considerably higher than today or otherwise the higher temperature would have resulted in extreme aridity and would have inhibited rather than promoted soil development.

Flow of the Carson River into the Carson Desert probably increased, bringing in more alluvium, for the sump areas were inundated by fairly permanent shallow lakes, in which highly organic silt, sand, and muck were deposited. The Churchill soil probably developed on the subaerially exposed basin-interior sediments, but it was removed throughout the lowlands at the close of Churchill time by waves of the lake transgression that developed into the early Sehoo lake.

\section{SEHOO TIME}

Lake-depositional history.-The Sehoo and Indian Lakes formations record the second general deep-lake period of Lake Lahontan. The lower, dendritic, and upper members of the Sehoo and their associated shore morphologic features record three deep-lake cycles during this period, and the intertonguing parts of the Indian Lakes and the thinolite unit of the Sehoo record important lake recessions after each lake maximum.

It is possible to get a much clearer picture of the lake-depositional history of Sehoo time than for Eetza and Wyemaha time, owing to excellent exposure of the Sehoo and Indian Lakes formations at all stratigraphic levels, even in the basin interior, their favorable stratigraphy, and well-preserved shore morphologic features.

During its transgression, the early Sehoo lake formed the most strongly marked shorelines of Sehoo time and deposited the coarsest and thickest gravel of the Sehoo formation, indicating strong waves, repeated strong windstorms, and probably many halts during the lake rise. On the shores most exposed to waves the upper several feet of earlier gravel were intensely reworked, so that only the larger boulders remained undisturbed; shore features of Eetza and alluvial fans of Wyemaha age were severely modified. At the main shoreline levels sizable spits and bars were built, in places extending 1 mile and locally over 2 miles from source hill shores across adjacent reentrants. Windstorms were probably less severe than those of Eetza time, however, for the shore gravel typically is less coarse, rock cutting is less in evidence, and constructional features generally are smaller. The distribution and orientation of shore ter- 
races, spits, and bars show that the strongest winds came mostly from the northwest and north and practically not at all from the south or southeast.

Much more sand was deposited on the highland shores than during Eetza time, because the lake reworked the extensive mantle of eolian sand of the Wyemaha. Tufa was deposited locally by algae growing near shore in shallow water. Maximum tufa deposition was between the 4,150- and 4,355-foot lake levels, particularly on headlands exposed to strong waves, forming in places a continuous blanket several inches to 1 foot or more thick. The final 15 feet of the lake transgression, however, was completely devoid of tufa deposition. While the lake rose from 4,175 to 4,330 feet, gastropods flourished in sheltered places-especially drowned mountain canyons-in greater numbers than at any other interval of Lake Lahontan history. Also probably during the lake transgression, a volcanic explosion at Soda Lake blew out mainly older basin-fill sediment and a small percentage of basaltic lapilli and bombs. The clay deposited on the lake bottom probably came mainly from turbidity currents generated by the Carson River and to negligible degree from local wash inflow or hill-shore erosion. The lake water was fresh, for the clay is nonsaline, but fish apparently were not numerous.

The lake maximum, at an altitude of about 4,370 feet, was only 10 feet below the highest Eetza maximum and inundated about 8,300 square miles. The highest level is marked by prominent terraces, bars, and spits, indicating a pronounced and stormy stillstand.

Between the early and middle Sehoo maximums the lake receded markedly but probably did not become entirely dry. During the recession from the early Sehoo maximum only a few well-marked shorelines were formed, mantled mainly with pebble and cobble gravel, attesting to infrequent strong windstorms and perhaps few stillstands. As the lake receded below the interbasin thresholds, it was split into separate lakes in various basins. When the lake level dropped below about 4,200 feet Walker Lake Basin was separated; at about 4,100 feet. The lake in the Pyramid-Winnemucca area was separated from that in the Hot Springs Valley and Carson Desert, and the latter was separated into two lakes when Ragtown Pass became exposed below about 4,050 feet.

While the recession was at and near its lowest levels, below an altitude of 4,040 feet, the thinolite unit was deposited. Thinolite, the distinctive sediment of this member, precipitated as euhedral crystals of aragonite in both shallow and deep offshore water. The marked thinness of lake-bottom clay in this unit compared with that in the lower and dendritic members, and the absence of well-marked shorelines suggest that thinolite time was brief compared with the deep-lake intervals of Sehoo time. The lake receded at least as low as 3,990 feet in the Carson Desert, at which level it inundated 1,500 square miles and was 125 feet deep. An incipient soil formed during the recession interval.

After the thinolite recession came the fourth deeplake cycle of Lake Lahontan, the middle Sehoo lake, when the dendritic member of the Sehoo was deposited. Only four clearly marked shorelines were formed during the lake rise; they are devoid of rock cutting and have only thin local shore sediments, rarely coarser than medium gravel, suggesting that the lake either rose with few pronounced stillstands and(or) that windstorms were infrequent and relatively mild. A particularly distinctive and abundant tufa, dendritic tufa, was deposited by algae growing near shore in shallow water; perhaps the algae flourished because the climate was unusually sunny and calm for a deep-lake interval. The Carson River added much sediment to its delta at the western edge of the Carson Desert.

The maximum of this lake was at about 4,190 feet, 200 feet above the known minimum of the thinolite recession; Lake Lahontan then inundated about 6,000 square miles and was a maximum of 325 feet deep in the Carson Desert. Waves were so weak and (or) the maximum stand so brief that the high shore is poorly marked. On its recession, the lake formed 13 faint to moderate shorelines, the best-marked ones being below 4,115 feet, and local pebble gravel was the coarsest shore sediment; waves obviously remained weak.

During late Sehoo recession time, when the upper tongue of the Indian Lakes formation was deposited and the Harmon School soil formed, the lake surface dropped at least as low as 3,900 feet; in other words, Lake Lahontan became nearly or completely dry. At this known minimum, the separate lake in the Carson Desert had a maximum depth of only 35 feet and an area of about 500 square miles.

The following late Sehoo lake is recorded by the upper member of the Sehoo formation. A distinctive lithoid tufa was deposited locally by algae during the lake rise. Absence of wave reworking of the tufa and of transgressive shorelines shows that the weather remained calm. At its maximum, about 3,990 feet, this lake inundated about 1,800 square miles and was 120 feet deep. The Carson River built a sandy delta 10 miles wide, which was graded to the high level, yet elsewhere the high shore is marked only by small local bars and beach terraces, attesting to weak waves. The Sagouspe fault zone was active, creating a prominent fault scarp in the lowlands. During the lake recession the Carson River flowed northward across this scarp, 
as now, and built another delta, about a third the size of the western delta, in the western Indian Lakes area.

History of subaerial erosion and deposition in the highlands.-Throughout Sehoo-Indian Lakes time subaerial erosion and deposition in the highlands were minor, and changes in subaerial processes with time were too small to provide contrasts in lithology or widespread disconformities within the Indian Lakes formation. Earlier alluvial fills were trenched a few feet along the middle reaches of the mountain washes, and small alluvial fans were built on the piedmonts. The coarseness, distribution, and structure of the alluvium show that it was deposited by torrential floods of normally dry washes that were larger than at any subsequent time. During the late Sehoo lake maximum alluvial gravel was carried farther into the interior of the basin than subsequently, in places as far as the lakeshore.

During the thinolite recession the Carson River trenched 60 to 100 feet into the delta it had built during the preceding lake stage and the trench was later filled by sediment of the middle Sehoo lake. This delta was trenched again during the late Sehoo recession and during late Sehoo lake time, when the floor of the trench was graded to a lower delta on the high shore of this lake.

Mass wasting also was more active than subsequently. Slope wash was the dominant colluvial process, and solifluction was subordinate. Earlier colluvium, above the calcareous horizon of the Cocoon soil, was locally moved, but the net modification of valley slopes was very minor. Block streams formed locally on mountain slopes by washing out of fines from solifluction mantel of Eetza age.

Some wind erosion, particularly of eolian sand of the Wyemaha formation, and eolian deposition probably took place in the highlands during the transgression of the early Sehoo lake, for this was a time of severe windstorms (p. 100). The remainder of Sehoo time was presumably relatively free from eolian erosion and deposition, for wave action apparently was weak and eolian sand is rare.

Soil development was practically nil during most of Sehoo-Indian Lakes time; the only discernible development was the incipient soil that formed during the thinolite recession and the very weak Harmon School soil that formed during the late Sehoo recession.

A moderate vegetal cover, probably mainly grasses and shrubs, probably existed throughout Sehoo time. A more abundant fauna than now seems to have been at least sporadically present. Perhaps the animalslion, horse, and camel-of early Sehoo age died out soon after early Sehoo time, for the small collection of mammal bones of thinolite recession age from Hidden Cave consists entirely of living species, and the large collection of vertebrate bones of the late Sehoo age from this site records a fauna similar to, but more abundant than, that of today, only Equus occidentalis being extinct.

Human occupation of the area may date from about the time of the middle Sehoo lake maximum (Grosscup, 1956), but conclusive stratigraphic evidence has not been obtained. The single projectile point discovered in place in upper lacustral clay by McGee (1889; Russell, 1885 , p. 246-247) is apparently of Sehoo age, probably middle Sehoo. A small nomadic Indian population occupied the area during late Sehoo lake time, judging from the archeologic record in Hidden Cave (Grosscup, 1956; Morrison, 1958c). The four projectile points found in Hidden Cave are unlike any points previously reported for the Humboldt Sink and Carson Desert areas, but resemble some from Dixie Valley, Nev., from the lowest level of Etna Cave, Nev., and from northeastern California.

\section{POST-LAKE LAHONTAN HISTORY}

\section{TURUPAH TIME}

Sehoo time was succeeded by an interval of marked aridity when the Carson Desert was completely dry much of the time and the Turupah formation was deposited. Turupah time and the following Toyeh interval are together equivalent to the altithermal age of Antevs (1948, p. 176-179), which has been dated from geologic and archeologic evidence and radiocarbon methods as starting 7,500 to 7,000 and ending 4,500 to 4,000 years ago (Heizer, 1951; Antevs, 1948, 1952, p. 103,1955 , p. $323,328-329)$. Probably the Turupah occupied all but the final 500 to 1,000 years or so.

Turupah time was characterized by eolian deposition and erosion. Large quantities of eolian sand were deposited, derived from sands of the Sehoo and Wyemaha formations, and large deflation basins and plains were created in the basin interior. Complete lake desiccation is evidenced by the marked deflation of Carson Sink itself and by widespread eolian sand of this age at altitudes below 3,890 feet. Deflation was most severe in the western lowlands; in many places the erosion went entirely through the Sehoo formation into the Wyemaha, locally removing 20 to 40 feet, and rarely more than 60 feet, of sediment. From 1 to 8 feet of sediment is estimated to have been removed over a large part of the lowlands-an aggregate volume of at least half a cubic mile in the map area. The sand was mostly redeposited within the basin as dunes and drift sheets of eolian sand of the 
Turupah formation; the finer fraction was partly deposited as a blanket of loess in the highlands and partly blown outside the basin. Deflation was easier during Turupah than during Fallon time because the Toyeh soil had not yet formed and its stabilizing effect was absent. In the highlands eolian sand of the Wyemaha and lake sand of the Sehoo were extensively reworked, but there was less wholesale eolian transport and deposition than in Wyemaha time.

The Carson River apparently rarely reached the Carson Desert, and the highland washes did not flow enough to leave recognizable alluvium. The paucity of fossil and archeologic remains suggests that flora and fauna were very sparse and that the area was generally uninhabited by man (Heizer, 1951, p. 92-95; Morrison, $1958 \mathrm{c})$. These conditions all betoken aridity more stark than now, which was possibly accentuated by temperatures higher than now as Antevs $(1948,1952)$ has suggested.

TOYEH INTERVAL

Turupah time was followed by the Toyeh interval, during which the Toyeh soil formed. Concomitantly plant cover increased, the dunes were stabilized, and deflation practically ceased. Though this interval probably lasted only a few hundred years, it produced the strongest soil development in all the time from the end of the Churchill interval to the presentprobably 20 to 60 times longer than the Toyeh interval. Soil formation probably was induced by relatively high temperature, perhaps continuing from Turupah time, coupled with an increase in precipitation that continued into first Fallon lake time.

\section{FALLON TIME}

DEPOSITIONAL HISTORY IN THE BASIN INTERIOR

General features.-The Fallon formation records at least five cycles of shallow lakes alternating with desiccation during the last 4,000 years or so. None of the desiccation intervals was as long, nor probably as arid, as Turupah time. The lakes ranged only from about 15 to 85 feet in maximum depth, each lower than its predecessor (table 7). The Carson River repeatedly changed its lower course, swinging in an arc of nearly $120^{\circ}$, and deposited a fan-shaped blanket of alluvium and deltaic sediment (pl. 11). Most of the time the river drained southeastward into the Carson Lake area, but occasionally it drained eastward toward the Stillwater Slough or the south end of the Stillwater Lakes, and twice it swung briefly northward toward Carson Sink. When the lakes were dry or nearly dry the river actually reached these areas; during the lake intervals it built deltas on the west shores of the lakes. Most of the deltas were graded to the lake maximums, and the sizes of the deltas were roughly proportional to the height of the corresponding lake, suggesting that maximum alluviation was synchronous with the lake maximums. The base level to which the river graded its flood plain has changed with the rise and fall of the lakes, but it trended generally downward, corresponding to the lake maximums; the flood plain was cut a few feet below the earlier deltas as the later ones formed.

First lake.-The first Fallon lake, recorded by the first lake unit of the Fallon formation, apparently had merely a single stillstand at and near its maximum level (3,948 feet), for transgressive and regressive shorelines are not evident. At its maximum it inundated about 1,140 square miles entirely within the Carson Desert and lower Humboldt Valley, and it had a maximum depth of about 85 feet. The Carson River flowed southeastward toward Carson Lake and its various distributaries built three sandy high-shore deltas, practically continuous and approximately coeval (table 7 ). Elsewhere along the high shore, lake sand was deposited by reworking of dunes of Turupah age. In deeper depressions away from the deltas, a few inches to a few feet of dark lake clay was deposited. The salinity of these sediments suggests that this lake was very saline.

Contemporaneous with the maximum of this lake, a separate lake seems to have existed at a lower level in Eightmile Flat. This lake probably was fed by subsurface seepage through the sand underlying the divide between Turupah and Eightmile Flats, for there is no sign of an overflow channel across this divide and local runoff from the drainage area of Eightmile Flat was inadequate to support such a lake.

First lake recession.-Recession between the first and second Fallon lakes is demonstrated by eolian sand and alluvium of the first interlake unit as low as about 3,910 feet in the Carson Lake area and about 3,900 feet in the Stillwater Lakes area-at least comparable to present conditions. This was a time of considerable dune construction and some deflection, particularly in the lowlands. About a foot of eolian silt and slope wash was deposited in Hidden Cave. Small gullies were dissected along Wildcat Scarp. Soil development was barely discernible.

Second lake.-During the transgression of the second lake, the Carson River built a small delta overlapping the easternmost delta of the first Fallon lake. At its maximum the lake reworked and beveled the margins of sand dunes built during the preceding drought and locally formed small bars of gravel and sand. In sandy areas above the lake eolian sand was added to earlier 
dunes. A faint shoreline marks a minor recessional stillstand at 3,927 feet.

Complete desiccation of the Carson Desert during the second interlake interval is suggested by local eolian sand, recording minor eolian erosion and deposition, as low as 3,880 feet. The very weakly developed L-Drain soil formed during this interval, representing the main soil development during Fallon time. The Carson River continued to drain to Carson Lake and built a large sandy delta on the north shore, which was graded to about the present level of this lake, which is almost dry. Stillwater Lakes and the Carson Sink probably remained completely dry.

Third lake.-The third lake of Fallon time was so shallow that the divide between Carson Lake and Stillwater Lakes, in the NW1/4, T. 18 N., R. 30 E., remained exposed and the lake maximums were not accordant in the southern and northern lowlands. These maximums are marked by faint shorelines and deltas, at an altitude of 3,922 feet in the southern (Carson Lake) area and at 3,915 feet in the northern area. The shore deposits in each area do not overlap; although approximately correlative, the lake maximums they record in each area may not have been quite synchronous. The southern lake maximum was controlled by overflow across the threshold to the northern area, then at about 3,921 feet, creating a narrow flood plain along the present Stillwater Slough which was graded to the high shoreline in the northern area. Probably late in third lake time the river shifted into its old northward channel-the present course-and built another small delta graded to a lake level at about 3,915 feet.

Remaining Fallon time.-The third lake was followed by marked recession, perhaps complete desiccation, then by two or more very shallow lake cycles. The Carson River shifted its course several times : mostly southeastward to Carson Lake, occasionally eastward to Stillwater Slough or the south end of Stillwater Lakes, and, least commonly, northward to Carson Sink. When the river drained to Carson Lake the lake maximums were controlled at an altitude of 3,919 feet by overflow across the threshold to the northern area, via the slightly entrenched Stillwater Slough. The maximum level was reached at least twice, long enough to develop a distinct though faint shoreline. When this lake overflowed, the Stillwater Lakes were flooded as, probably at times, was the Carson Sink. The northern lakes probably fluctuated even more than the seasonal variations in river discharge, because evaporation from Carson Lake and the lower chain of lakes tended to accentuate these variations. When the river drained directly into the northern area, Carson Lake remained entirely dry, as none of the late Fallon lakes in the northern area rose high enough to overflow the threshold into Carson Lake. Thus there were many more small lake fluctuations in the northern area than in the Carson Lake area, and Carson Sink probably was dry much more of the time than Carson Lake or the Stillwater Lakes.

The Humboldt River also terminates in Carson Sink and therefore the sink probably also received intermittent inflow from this river. Historic records of discharge suggest, however, that this inflow tends to be proportionate to, but generally less than, the discharge of the Carson River into the Carson Desert; hence, its effect is assumed to have been subordinate to inflow from the Carson River, even in the northern part of the basin.

The two highest lake maximums in the northern area were successively at about 3,905 and 3,890 feet. The 3,905-foot maximum cannot be correlated with the maximums of Carson Lake; the 3,890-foot maximum was reached in 1862, but may also have been reached earlier.

Published records show that Carson Lake was at its overflow level-at an altitude of 3,919 feet-in 1845 (Kern, 1876), 1859 (Simpson, 1876), 1862, 1866, 1873, 1881, 1883, and 1885 (Russell, 1885, p. 44-45). It probably was generally below this level during the 1840 's, for this decade was a drought period in the region (Antevs, 1938b). Recent minimums were in 1904, 1919, and 1924-1934. Carson Sink generally was dry during the 1840 's and from 1880 until 1905 . It reached its highest modern inundation in 1862, after the largest floods of historic time in the Carson and Humboldt Rivers. (The Humboldt River apparently contributed considerable inflow at this time, for a waterpowered grist mill was in operation at White Plains station, halfway between Humboldt Lake and the mouth of the river.) In 1863 , when the first public land surveys were made in the Carson Desert, the sink was inundated to a depth of about 20 feet, and Pelican Island actually was an island. The sink was completely dry when Russell $(1885$, p. 68) visited it in October 1881.

Russell (1885, p. 44-45) outlined the modern history of the changes in course of the lower Carson River and the history of the lake fluctuations as follows:

Previous to $\mathbf{1 8 6 2}$ it flowed into the South Carson Lake, but there was an abandoned channel branching from it and leading northward. During a time of unusually high water in the spring of 1862 the river bifurcated, the old channel was reoccupied and a branch flowed to each lake ***. Previous to that time there was a "slough" connecting North and South Carson Lakes thru which the waters flowed northward. After the forking of the stream the South lake was lowered so that it no longer overflowed and the water in the slough became stagnant. Another flood occurred in the spring of 1867 or 1869 , which caused the arm emptying into North Carson Lake to branch and send a stream eastward to the slough. The last-formed channel is still occupied and is known as "New River." This distribution of the waters of the Carson still continues $* * *$. In June, 1859, 
the water in the slough was reported by Captain Simpson to be 50 feet wide and 3 or 4 feet deep, and flowing northward with a strong current. In September 1866, Lieut. R. Birnie states that the waters were sluggish, with scarcely a perceptible flow. In June, 1881, I found the volume of water about the same as reported by Simpson in 1859, and flowing northward with a wellmarked current. In September, 1883, the slough was low, and did not exhibit any motion; South Carson Lake at the same time was very shallow, much of it presenting the appearance of a swamp.

Russell (1885, p. 69) also mentioned that in 1882 Carson Lake had an area of about 40 square miles and a depth of about 4 feet in its central part.

Since development of the Newlands Reclamation Project, which started in 1905, the channels of the Carson River and Stillwater Slough have been straightened and locally deepened, the river channel has been stabilized in its northward course to Carson Sink, and the river discharge has been controlled by construction of Lahontan Dam and several small diversion dams. In 1907 the second largest flood in historic time occurred on the Carson River, causing a temporary diversion past the south edge of Fallon and thence into Stillwater Slough.

As a result of the shifts of the Carson River and lake inundations, the flood plain grew and several small deltas were built on the north shore of Carson Lake, near Stillwater, and at the edge of Carson Sink. Eolian erosion and deposition continued, reshaping the sand dunes, and to a slight degree, the deflation basins. Where eolian sand was successively inundated by the shallow lakes, eolian and lake sand were intricately interbedded.

\section{EROSIONAL AND DEPOSITIONAL HISTORY IN THE HIGHLANDS}

During Fallon time the highland washes deposited a little alluvium on their fans, but much less than during late Sehoo lake time. The poor sorting, great range in grain size, and high angularity of the alluvium reflects its dominantly rapid transport and deposition by flash floods after infrequent heavy rains. Large differences in volume of alluvium between washes of similar drainage area show that the torrential rains were spotty, causing big floods in one canyon and little or none in a neighboring one, but the generally small volume shows that most canyons and washes had few big floods. The episodes of alluviation cannot be precisely correlated with the lake intervals, but the main activity clearly was early. Degradation of the highland washes was imperceptible. The historic arroyo cutting that was dominant in most of the Western United States, including many less arid parts of Nevada, has not yet affected any of the washes in the area.
Slight colluvial activity took place on the mountain slopes, but it was infinitesimal compared with that during Eetza and Sehoo times; the record in Hidden Cave suggests that the total amount of such activity was less than during late Sehoo time alone, and that it virtually stopped during the driest intervals. Mass wasting is most active at present in the highest mountains of the region where rainfall and snow accumulation are greatest.

Eolian erosion and deposition took place intermittently and locally in the highlands on a small scale, centering in the lower highland passes that had received extensive earlier accumulations of eolian and lake sand.

\section{HUMAN OCCUPATION}

Nomadic Indians occupied the area intermittently during Fallon time, living close to the lakes and streams. The density of occupation seems to have fluctuated with lake levels, being greatest when the lakes were highest and least when they were desiccated, although sparse temporary occupation may have persisted along the Carson River and perennial springs through some of the dry intervals. Doubtless the density fluctuation was due to corresponding variations in the food supply.

The time of the first Fallon lake was one of sparse inhabitation, as recorded by the few artifacts in the socalled 32-inch midden layer in Hidden Cave (Grosscup, 1956, p. 61) and by rare occupation sites along the high shore of this lake. Probably Indians did not return to the area quickly after the depopulation of Turupah time. Inhabitation also was sparse during the first lake recession, and clustered mainly around the shore of the shrunken Carson Lake. The loess layer in Hidden Cave that is correlated with the first Fallon lake recession is almost barren of artifacts.

Indian inhabitation reached its all-time climax during the time of the second lake, as shown by many open sites along the high shore and by a conspicuous midden layer in Hidden Cave, which contained 85 percent of the artifacts recovered during the 1951 excavations at this site (Grosscup, 1956). Inhabitation again was sparse during the second lake recession, and clustered mainly around Carson Lake. Later Fallon time seems to have been a time of sparse to moderate occupation, when the Indians lived mainly in open sites near the permanent lakes and watercourses.

Grosscup (1956, p. 61-63) correlates the cultural material of first- to second-lake age with the Lovelock culture of the Humboldt Lake area (Loud and Harrington, 1929; Heizer, 1951, 1956; Heizer and Krieger, 1956) and the artifacts of later Fallon age with prehistoric and historic Northern Paiute. 


\section{CLIMATIC HISTORY}

The record of Fallon time-deposits, fossils, archeology, and geomorphic features-attests to small climatic fluctuations, but without marked differences from the present climate. During the desiccation intervals the climate probably was about like now, except during the second lake recession it may have become slightly warmer, as suggested by the fact that the only appreciable soil development of Fallon time took place then. The lake intervals were probably both cooler and wetter than climate today. The first lake maximum marked the moisture maximum and probably the temperature minimum for all Fallon time; however, it is doubtful whether annual precipitation increased more than several inches or temperature decreased more than a few degrees from present values.

The indication of the lake record that the magnitude of the wetter cooler fluctuations that produced the lakes steadily diminished toward the present suggests that the general trend in climate during the 3,000 or 3,500 years since the first Fallon lake maximum has been toward increasing aridity and possibly greater warmth. Such an established trend is likely to continue into the future, with of course temporary reversals. Antevs (1938b) analyzed the very recent climatic cycles of this region and predicted the climatic fluctuations for several decades; his forecast is proving to be remarkably accurate.

Fallon time seems to have been one of moderate windiness, judging from its eolian deposits and eolian erosion features-less windy than Turupah time but generally more windy than the later part of the Sehoo time. The desiccation intervals apparently were generally windier than the lake intervals, for most of the eolian sand seems to have been deposited during the desiccation intervals; moreover, the higher shorelines of the lakes generally show little evidence of strong wave action. The modern deposits of eolian sand suggest that windiness recently has increased: areas of active dunes seem generally to be growing, and the more recently deposited beds in the dunes commonly are coarser than the earlier beds.

The early winter of 1825 is reported to have been exceptionally cold - so cold that all buffalo in the Great Basin west of the Rockies were killed (Simpson, 1876). A severe drought occurred in the 1840's. The period from 1850 to 1923 was generally abnormally wet; the levels reached by the principal lakes of the region between 1850 and 1919 were the highest in 200 years or more (Antevs, 1948, p. 180). From 1824 through 1934 precipitation and runoff were subnormal in the northwestern part of the Great Basin, and temperature was above normal; these conditions produced the most severe drought in 150 to more than 650 years (Antevs, 1948, p. 182).

\section{COMPARISONS WITH PREVIOUS INTERPRETATIONS}

Russell's interpretation.-Russell's (1885) conclusions on Lake Lahontan are as follows: Lake Lahontan had two high-water periods, represented by the "lower lacustral clays" and "upper lacustral clays," and an intervening period of low water and probably complete desiccation, represented by "medial gravels" (fig. 38). The first lake lasted longer than the second, but the rise of the second was more abrupt, and its maximum was about 30 feet higher. The maximum of the first lake is marked by the lithoid terrace 500 feet above the 1882 level of Pyramid Lake, which is 3,867 feet according to Antevs (1945, p. 29, 30) making this maximum an altitude of 4,367 feet; deposition of lithoid tufa was restricted to the recessional phase of this lake. Pyramid Lake, which is the lowest of the major sinks in the Lake Lahontan drainage area, may have become completely dry during the middle Lake Lahontan desiccation. During the transgression of the second lake, there was a long stillstand at the level of the thinolite terrace and a short one at the dendritic terrace, 110 and 320 feet, respectively, above the 1882 level of Pyramid Lake (at altitudes of 3,977 and 4,187 feet) and thinolite tufa was deposited as high as the thinolite terrace and dendritic tufa as high as the dendritic terrace. The Lahontan beach marks the maximum of the second lake, 530 feet above the 1882 level of Pyramid Lake (altitude 4,397 feet). Pyramid, Winnemucca, and Walker Lakes probably dried up completely during an interval more arid and warmer than now between the time of the second lake and the present, because these lakes do not contain as large a concentration of salts as they should if they were mere shrunken remnants of Lake Lahontan. This was the earliest deduction of the warm arid interval which is now recognized throughout the world as the thermal maximum, and which in the Great Basin has been called the altithermal age (Antevs, 1948, 1952).

Antevs' interpretation.-Antevs (1925a) first concluded, from a series of stratigraphic sections measured along the valleys from the Truckee, Humboldt, and Walker Rivers, that Lake Lahontan had three and perhaps four high-water stages, separated by intervals of low water or complete desiccation. More recently, (1945, p. $30-31 ; 1948$, p. $171 ; 1952$, p. 100-101) however, he inferred only two high-water cycles (fig. 38), separated by an interval of partial lake recession. The first lake, "Lake Lahontan proper," rose the highest, to 4,397 feet at Pyramid Lake; the following recession, the "Thinolite Lake," was to the level of the thinolite 


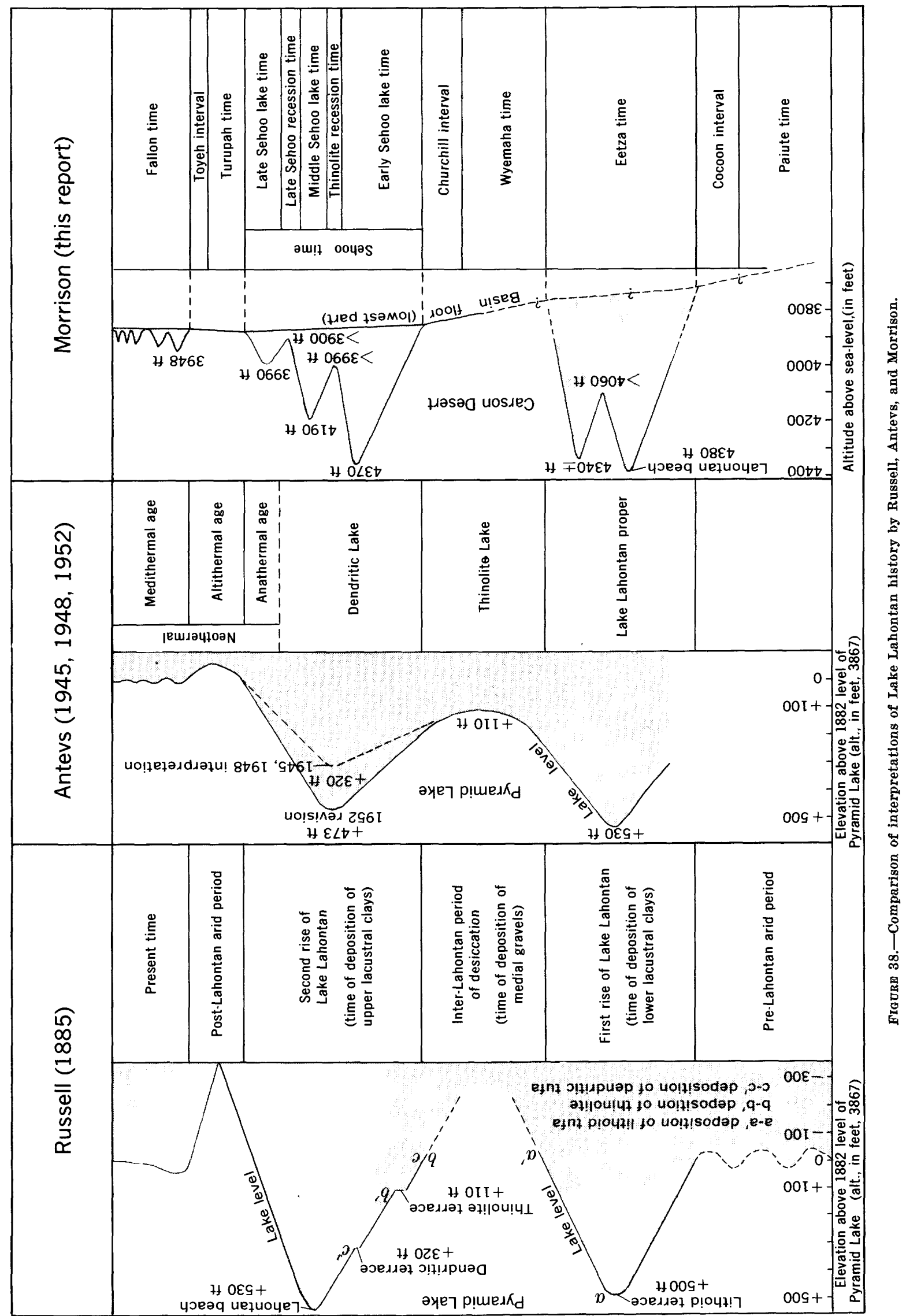


terrace, altitude 3,977 feet; and the next younger "Dendritic Lake" rose to a maximum of 4,197 feet (1945, p. $31 ; 1948$, p. 171), which was later revised to 4,340 feet $(1952$, p. 101) from work in the Humboldt Valley. Later Antevs (1955, p. 326) assigned an age of 24,000 years to the "Lahontan II" maximum (probably his former "Dendritic Lake" maximum), which corresponds to the early Sehoo maximum of this report. He postulated a fairly regular decline in lake level from this maximum, with minor recessions and six subsidiary maximums. (The data on the recessional-lake oscillations were derived from studies by the writer (Morrison, 1852a, considerably reinterpreted), by Stanley (1949), and by Antevs himself.) He gave an age of 18,000 years for the maximum corresponding to that of the middle Sehoo, and 10,000 years for that of the late Sehoo. Like Russell (1948, p. 176, 178-179), Antevs considered that Lake Lahontan dried up fairly completely during the thermal maximum, which he called the altithermal age, between 4,500 and 7,000 years ago. His published graph of lake fluctuations, however, does not indicate complete desiccation of Pyramid Lake. More recently the lakes such as Pyramid, Winnemucca, and Walker, were again inundated.

Jones' interpretation.-J. C. Jones $(1914,1925,1929)$ believed that Lake Lahontan had only a single lake cycle commencing only 2,000 or so years ago, and he inferred that all the beach lines and shore deposits represent only the maximum or recessional stages. He reasoned that any previous shorelines or shore deposits would be largely obscured and obliterated by this lake cycle. He also concluded that the parts of the sections in the Humboldt and Walker Canyons that Russell designated as medial gravels and lower lacustral clays are both subaerial ("typical alluvial fan and playa deposits"), and that only the part designated as upper lacustral clay is truly lacustrine; in the Truckee canyon, however, all three members are lacustrine. The bulk of the tufa deposition was near the close of the lake recession.

Comparison with the writer's interpretation.-The writer's conclusions on the lake history gave no support to Jones' interpretation of a single and very young lake cycle. They agree, however, with most of Russell's and Antev's conclusions, although they supplement or contradict them in several details, as follows (fig. 38) :

1. Contrary to Antev's interpretation, but in line with Russell's, the lake became completely dry during the middle Lake Lahontan recession (Wyemaha time), at least in the Carson Desert.

2. In agreement with Antevs, but not Russell, the highest lake maximum was during the first main deep-lake period (Eetza time), not during the second (Sehoo time).

3. Contrary to both interpretations, both of the main deep-lake periods had multiple maximums.

4. Likewise, several low lake cycles occurred in postLake Lahontan (Fallon) time.

5. Lithoid tufa was deposited intermittently throughout Lake Lahontan and Fallon time, not just on the recession of the first high-water period, as Russell believed.

6. Thinolite tufa is younger than Russell and Anters believed, at least in the Carson Desert. Russell concluded that it was formed early on the rise of the second Lahontan Lake; Anters, during the middle lake Lahontan recession. According to the present study, it was deposited mainly near the minimum of the recession between the early and middle Sehoo lake maxima, although a little also was deposited near the end of the middle Sehoo lake.

\section{CORRELATION AND AGE OF THE QUATERNARY DEPOSITS AND SOILS}

\section{MEANS OF CORRELATION}

Correlation of the Lahontan Valley group and Fallon formation with late Quaternary deposits in other areas in the Western United States is difficult because: deposits commonly are dissimilar and generally contain no sedimentary time-parallel marker that persist from one area to another; fossils not only are generally scanty but also non diagnostic for the small time spans involved; radiocarbon age determinations are few and cover only the younger part of late Quaternary time; and other means of absolute age determination such as rate of increase in salinity in lakes without outlet (Jones, J. C., 1925, p. 28-42, and 1929; Van Winkel, 1914 , p. 123), rate of concentration of fluorine in bones, rate of deposition of alluvium and travertine and rate of weathering, soil development, or leaching, are hopelessly unreliable. Two criteria are considered reasonably reliable and are the principal means of timestratigraphic correlation of rock-stratigraphic units used in this report: (a) the position of rock units in successions of depositional cycles (manifested by records of lacustrine, glacial, alluvial, and eolian deposition and erosion), and (b) the position of rock units in relation to soil sequences, compared in terms of relative stratigraphic position (age) and relative degree of soil development. Neither of the criteria is wholly reliable alone, but in combination they are believed to be the best geologic means of correlation available. Fossil and other evidence are subsidiary means. 
Correlation by position in successions of depositional cycles.-Correlation by position of stratigraphic units in successions of depositional cycles is the traditional means of correlating Quaternary deposits. The depositional cycles are revealed by records of glacial, lacustrine, alluvial, colluvial, eolian, and marine deposition and erosion, and by soil development. They manifest fluctuations such as advances and retreats of glaciers, rises and falls of lakes, eustatic shifts in sea level, and changes in type and rate of alluviation, mass wasting, soil development, and erosion. These cycles are assumed to be induced by general climatic changes, virtually worldwide and synchronous. Some idea generally can be gained of the amplitude and duration of the depositional cycles from the distribution, thickness, and lithologic character of the deposits. By matching the successions of these cycles in separate areas, the sequences of deposits that record them can be correlated.

Long-distance correlation solely by this means is confounded, however, by many uncertainties. Commonly one cannot be certain that he has correctly identified the same depositional cycle (or position in this cycle) in the sequences in different areas. Correlation also may be hampered by the complexity of the record in one area and its meagerness in another, and by such nonclimatic variables as diastrophism. Moreover, depositional cycles of one type are not necessarily synchronous with those of another (cycles of glaciation with cycles of alluviation or with eustatic shifts in sea level). Also, parts (stades) of cycles of the same type may not be exactly synchronous from area to area (a given glacial stade probably lasted longer in Montana than in the Rocky Mountains of New Mexico although its deposits have similar relative position in the stratigraphic sequences of both areas).

Correlation by position in relation to soil sequences.Many of the above uncertainties can be minimized by using the position of rock-stratigraphic units in relation to soil sequences as the primary means of correlation, and using their position in successions of depositional cycles in combination as secondary means. Richmond $(1950,1962)$ has observed that if the successions of late Quatemary deposits and soils in various parts of the western United States are compared, the soils show striking coincidence of their relative degree of development and their relative age relations. From the constancy of their relative development and age relations from area to area, it is obvious that the soils at least are rock-stratigraphic markers from area to area, and the stronger soils are among the best markers.

The later Quaternary stratigraphic successions of the Carson Desert, Lake Bonneville, and Sierra Nevada areas, for example (pl. 12), all have similar soil se- quences, in terms of relative age and relative development of the soils. In each area, the soils formed during distinct, widely separated intervals, in response to relatively infrequent combinations of climatic factors that induced erosional stability and a more rapid rate of chemical weathering than normal. Stronger soils developed during the main intervals of lake desiccation and of deglaciation, weaker soils during the shorter recession intervals and at other times soil profile development was inappreciable. The soil-forming intervals were periodically repeated parts of whole climatic cycles-mainly fluctuations in temperature and precipitation-that are manifest in the Quaternary sequences of each area. The climatic cycles, and the depositional cycles and soil-forming intervals induced by them, probably were virtually synchronous over the entire Sierra Nevada-Great Basin-Rocky Mountain region because the whole region probably acted as a climatic unit during the Quaternary, as it does now. Consequently, the soils are assumed to have formed contemporaneously, in other words to be virtually time-parallel, throughout this region. Because they formed during generally shorter intervals than the intersoil sediments, the soils are considered to be more precise time-stratigraphic markers.

The stronger soils are easily recognizable in the successions of each area and are the most reliable and useful markers, providing the basic framework for correlation. The sediments and weaker soils intermediate in age between the main soils are correlated by matching those units that record depositional cycles, or parts of cycles, of similar relative age and similar climatic genesis, that is, by matching units which record early lake cycles with each other and with units recording early glacial cycles; likewise, lake-recessional units are correlated with glacial-recessional units.

It is necessary to emphasize that in using soils for correlation, the relative development of the individual soils is compared, not their absolute development. A given soil may vary considerably in its absolute characteristics from one area to another yet be similar in its degree of development relative to the other soils in each area. Regional correlation cannot be made on the basis of a single soil, because it is necessary to compare sequences of soils of several ages in each area in order to determine relative development. Such sequences should contain at least two and preferably three soils that are moderately or strongly developed, because weakly developed soils are unreliable time-stratigraphic markers. In making the comparison, moreover, the effects of local environmental factors must be minimized as far as possible, particularly differences in parent material, slope, and drainage. Regional differences in climate are the 
principal determinants of soil facies of a strongly developed soil. They generally cannot be eliminated, but because they affect all the soils of a given locality in similar relative degree, they do not alter the degrees of development of the soils in relation to each other.

To date, soils have been used successfully only for correlation of late Quaternary deposits, generally those of Wisconsin and younger age. This is because preWisconsin soils, such as the Cocoon is thought to be, generally cannot be differentiated except where they are buried and in stratigraphic superposition in the same exposure.

CORRELATION OF THE COCOON, CHURCHILL, AND TOYEH SOILS, LAHONTAN VALLEY GROUP, AND FALLON FORMATION, WITH LATE QUATERNARY SOILS AND DEPOSITS IN THE LAKE BONNEVILLE, SIERRA NEVADA, AND MONO LAKE AREAS

Correlation with the Lake Bonneville area and Sierra Nevada.-Correlation by means of soils and depositional cycles obviously requires reasonably complete stratigraphic information in the separate areas to be correlated. Adequate data are available for the Lake Bonneville area from the reports of Hunt and others (1953), Bissell (1952, 1962), Jones and Marsell (1955), Eardley and others (1957), and Morrison (1961b and c) to enable rather detailed correlation with the late Quaternary succession of the Carson Desert. Less complete data are available for the Sierra Nevada, in papers by Blackwelder (1931), Putnam $(1949,1950)$, Matthes (1942), and in unpublished field notes by the writer, permitting only generalized correlation. The deposits of the intervening areas have not been studied sufficiently to permit direct tracing of units from one area to another. None of the mountains bordering the Carson Desert were glaciated during the Pleistocene, the nearest Pleistocene glaciation being in the Sierra Nevada more than 80 miles to the west, and Lake Lahontan did not transgress any of the moraines.

Plate 12 shows the correlations the writer has developed between the late Quaternary deposits and soils of these three areas, and the two means of correlation: First, soils of similar relative developments are correlated, starting with the three youngest most strongly developed soils; then, between each main soil, the deposits that record depositional cycles of similar size, or parts of such cycles, are correlated, as are any weakly developed soils.

The Cocoon soil is correlated with the pre-Lake Bonneville soil on the upper pre-Lake Bonneville Pleistocene deposits, and with the inter-Tahoe-Sherwin soil in the Sierra Nevada. The Churchill soil is correlated with the middle Lake Bonneville soil and the
inter-Tahoe-Tioga soil. The Toyeh soil is correlated with the post-Lake Bonneville and post-Tioga soils.

The deposits intermediate in age between these main soils are correlated as follows: The Eetza formation is correlated with the Alpine and Bonneville formations and the main part of the Provo formation of Hunt (in Hunt and others, 1953) ${ }^{3}$ in the Lake Bonneville area, and with deposits of the Tahoe glaciation in the Sierra Nevada. The Wyemaha formation is correlated with the disconformity and subaerial deposits of intra-Provo age in the Lake Bonneville area and with the disconformity of inter-Tahoe-Tioga age in the Sierra Nevada. The Sehoo and Indian Lakes formations are correlated with the uppermost part of the Provo formation (above the intra-Provo disconformity) in the Lake Bonneville area, and with deposits of the Tioga glaciation in the Sierra Nevada. The Turupah formation is correlated with a disconformity between deposits of the Tioga glaciation and of the Little Ice Age of Matthes (1942) in the Sierra Nevada. The Fallon formation probably correlates with the deposits of Utah Lake (Bissell, 1962) in the Lake Bonneville area and with the deposits of the Little Ice Age of Matthes in the Sierra Nevada. The first Fallon lake maximum may correlate with the 4,262-foot strandline above Great Salt Lake, which Antevs (1952, p. 104) suggests may be - the highest stand of this lake during his medithermal age.

Correlation with Mono Lake area.-Putnam (1949) correlated the oldest high-water hemicycle of ancestral Mono Lake (which he named Lake Russell), represented by a faint shoreline at altitudes of 7,170 to 7,180 feet, with the Tahoe stage, and a somewhat lower and fresher high shoreline with the Tioga stage. Thus, the older lake cycle of Lake Russell presumably correlates with Eetza time of Lake Lahontan, and the younger lake cycle with early and (or) middle Sehoo time. The younger part of the pumiceous tuff at Mono Craters overlies the Tioga recessional moraines and may in part correlate with the ash parting near the base of the Turupah formation.

\footnotetext{
${ }^{3}$ Fieldwork by the writer in 1958 and 1959 in the Lower Jordan Valley (Midvale-Draper area), Utah, suggested a modification of Funt's (in Hunt and others, 1953) interpretation of the lake history recorded by the Provo formation as mapped by him in northern Utah Valley. A major disconformity, a strong soll, and local alluvium were found intercalated between lower (main) and upper parts of the Provo formation. The disconformity and soil were traced to altitudes as low as 4,350 feet. In addition, two successive minor disconformities were identified in the upper part of the Provo formation. These data indicate that, after a long stillstand at the Provo level $(4,820$ to 4,800 feet), Lake Bonneville receded below 4,350 feet, probably to complete desiccation. The lake then rose to about 4,770 feet, then fell below 4,450 feet, again rose to about 4,470 feet, next receded below 4,375 feet, and then rose to about 4,410 feet, before its final desiccation.
} 
COMPARISON WITH PREVIOUS CORRELATIONS OF LAKES LAHONTAN AND BONNEVILLE

The foregoing differs rather markedly from previous correlations of Lakes Lahontan and Bonneville. The previous correlations have been based on coincidence of inferred lake cycles; the workers assumed that climatic changes caused the lake fluctuations, and that these changes were synchronous in the two lake basins because the whole area acted during the Pleistocene as a climatic unit, as it does now. These assumptions are accepted, but the writer disagrees with each of the previous correlations and interpretations of lake history on one or more points. Previous interpretations of lake history in the Lake Lahontan area are compared with the writer's in a following section, and a similar analysis for the Lake Bonneville area is in preparation.

Russell (1885, p. 269) and Gilbert (1890, p. 264, 317) agreed that the two lake cycles inferred for each lake were synchronous. They followed King $(1878$, p. 524) in believing that this lake history lasted the entire Pleistocene, and they correlated the two high-water lake cycles with the two stages of Cordilleran glaciation in the West and of continental glaciation in the Central and Eastern States that were then known.

Merriam $(1917,1919)$ concluded that the first highwater period occurred during Nebraskan time, on the basis of the number of extinct vertibrate fossils supposedly from deposits of this period, but this interpretation is questionable (Jones, J. C., 1925, p. 49-50; Hubbs and Miller, 1948, p. 24; Schultz and others, 1951, table 1). At the opposite extreme, J. C. Jones (1925, 1929) concluded that Lake Lahontan was far younger than the high-water periods of Lake Bonneville.

Antevs $(1945,1948,1952)$ believed that Lakes Lahontan and Bonneville both had only two high-water hemicycles in Wisconsin time and correlated "Lake Lahontan proper" with "Lake Bonneville proper" and the Tahoe stage, and the "Dendritic Lake" with "Lake Provo" and the Tioga stage (fig. 38). This implies correlating the Sehoo formation with the whole Provo, and the Eetza formation with the Bonneville formation alone. Antevs inferred only partial recessions in middle Lake Lahontan and middle Lake Bonneville time and he correlated with each other these two lower lake levels, which he called the Thinolite and Stansbury I Lakes, respectively.

Deevey's correlation of the two lakes $(1953$, p. 297) follows Antevs' interpretation of lake history and his correlation.

\section{EVIDENCE ON ABSOLUTE AGE}

Age from rate of salt accumulation.-Russell considered determining the age of Lake Lahontan from the rate of salt accumulation (Russell, 1885, p. 224-227). He concluded that the salinity of water in Pyramid, Winnemucca, and Walker Lakes was much less than it should be if these lakes were the concentrated residues of the former great lake. He therefore postulated a post-Lake Lahontan interval of complete desiccation, during which the salts were precipitated and largely buried beneath sediment. The present lakes formed anew after this desiccation, he believed, and their present salt content accumulated since that time. Although Russell had few chemical or stratigraphic data, subsequent studies have confirmed his inferences.

J. C. Jones (1925) later applied this method in more detail, and arrived at an estimate of about 2,000 years (op. cit. p. 42, 47) or 3,000 years (op. cit., p. 4) for the total age of Lake Lahontan, and about 1,000 years ago for the lake maximum. Modern stratigraphic correlations and radiocarbon data indicate that these ages are much too low, probably by a factor of 20 to 50 times. Jones was also in error in assuming that the lakes had never gone dry since their inception.

Antevs' estimates.-Antevs has presented (1945, 1948, 1952) a detailed chronology based on extensive geochronologic research. His latest estimates (1952, 1955) place the Bonneville-Lahontan Lake maximum at perhaps 55,000 to 60,000 years ago, the Provo-Dendritic (early Sehoo) lake maximum about 24,000 years ago, the middle Sehoo maximum about 18,000 , the late Sehoo maximum at 10,000, and the first medithermal (Fallon) lake maximum at 3,500 years ago. Antevs' altithermal age corresponds to Turupah and Toyeh time of this report, and his medithermal age to Fallon time.

Radiocarbon dating. - By the end of $1956^{4}$ a dozen published radiocarbon dates were available from young deposits at four archeologic sites near Lake Lahontan but outside the map area. Figure 39 lists them and their relations to associated deposits and archeologic cultures. On the basis of these dates, the archeologic chronology determined by Heizer (1951, 1956), the estimates by Antevs $(1945,1948,1952)$, and the writer's correlations, Fallon time is estimated to have lasted from about 2,000 B.C. to the present, the Toyeh interval from 3,000 or 2,500 B.C. to about 2,000 B.C., and Turupah time from 5,500 or 5,000 B.C. to about 3,000 or 2,500 B.C.

The bearing of the two oldest dates, 9,249 B.C. at Leonard rock shelter and 8,950 B.C. at Fishbone Cove, on late Lahontan Valley chronology is uncertain, as the material directly beneath the dated samples can-

\footnotetext{
$4 \mathrm{By}$ the end of $1959,61 \mathrm{C}_{14}$ age determinations had been run on samples from the Lake Lahontan area, 11 from the southern Carson Desert. Some of these dates seem to fit reasonably well into the correlation scheme proposed in this report and the currently most geneally accepted chronology, but others do not, and several internal inconsistencies are clearly evident.
} 


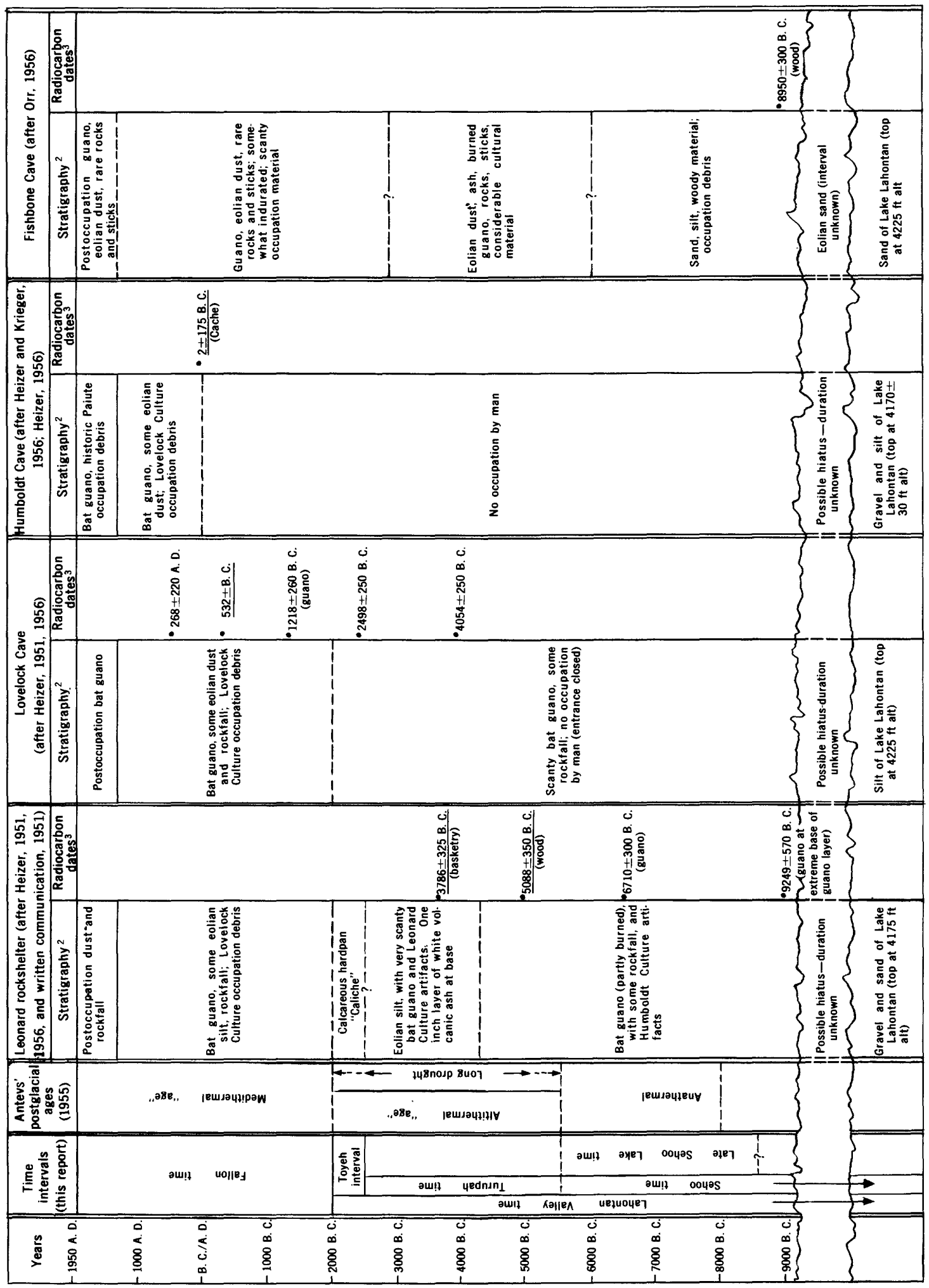


not be correlated accurately. The samples may represent either the late or the middle Sehoo lake, as they lie close to the altitude of the late Sehoo lake maximum. If these radiocarbon dates are correct, they correlate approximately with the Two Creeks interval (as used by Flint, 1947) of late Wisconsin time in the NorthCentral States, suggesting that the immediately underlying sediments of Lake Lahontan (either the dendritic or the lower member of the Sehoo formation) correlate with the Cary substage in the North-Central States.

\section{GENERAL DEDUCTIONS ON LATE QUATERNARY COR- RELATION, CLIMATIC HISTORY, AND SOIL DEVEL- OPMENT IN THE NORTHERN GREAT BASIN AND ADJOINING MOUNTAINS}

The following general deductions are drawn from the data on stratigraphy and climatic history of the Carson Desert area, from the correlation of the Quaternary deposits of this area with those of the Lake Bonneville and Sierra Nevada areas, and from the inferred lake and glacial fluctuations.

\section{SYNCHRONY OF THE FLUCTUATIONS OF LAKES LAHONTAN AND BONNEVILLE}

Plate 12, which correlates the deposits, soils, and lake and glacial fluctuations of Lake Lahontan, Lake Bonneville, and the Sierra Nevada, was constructed by first correlating soils of similar relative development in each area, then between these main soils, correlating deposits that record depositional cycles of similar size. If this diagram is correct, it appears that Lakes Lahontan and Bonneville fluctuated practically in unison; oscillations of similar relative magnitude were synchronous whether they were major or minor lake cycles, or partial or complete lake recessions. Differences between the two lakes in relative heights of lake cycles of the same age occurred mainly because Lake Bonneville overflowed during its second, third, and possibly fourth lake maximums. If the fluctuations of both lakes were coincident, they could only have been due to closely similar climatic changes throughout their combined drainage areas, and the record of climatic changes which is preserved in the stratigraphic sections of the lake basins probably is representative for a large part of the Western United States.

\section{RELATIONS OF THE LAKES TO MOUNTAIN GLACIATION}

From the correlations diagrammed on plate 12 , it seems that the fluctuations of Lakes Bonneville and Lahontan were virtually synchronous with oscilla- tions of glaciers in the Sierra Nevada, and that fluctuations of a given age were similar in relative magnitude in both lakes and glaciers. Big lake cycles were coeval with big glacial cycles, small lake cycles with small glacial cycles (where the records are reasonably complete), and desiccation intervals with times of deglaciation.

The stratigraphic records in the lake basins seem to give a more complete account of the lake fluctuations than those in the mountains give of the glacial oscillations. The lake record gives indirect evidence of several small glacial oscillations not yet recognized in the glacial record. For instance, the two major lake cycles during Eetza time suggest that the Tahoe stage of Blackwelder (1931) in the Sierra Nevada was not a single glaciation, but two, with an intervening short glacial recession. Similarly, the 3 lake cycles and 2 recessions during Sehoo time probably were parallel with similar oscillations of the mountain glaciers, although at present only 2 glacial substages and 1 interglacial substage are recognized in the correlative Tioga stage of Blackwelder (1931) in the Sierra Nevada. In particular, the upper member of the Indian Lakes formation and Harmon School soil record a time of practically complete lake desiccation and moderate warmth during the later part of Sehoo time; this interval probably was coeval with an interglacial interval in the western cordillera, although it has not yet been specifically identified in the glacial record.

The long-lasting desiccation and warmth of Wyemaha-Churchill time, indicated not only by the Carson Desert record (p. 99) but also by that in the Lake Bonneville area (Bissell, 1952; Durrant, 1952, p. 493496 ; Jones, D. J., and Marsell, 1955, p. 98-99), strongly suggests that this was a time of complete deglaciation of the Sierra Nevada and Rocky Mountains-a true interglacial stage, not merely an interval of partial glacial recession as Anters $(1945,1948,1952)$ postulated.

\section{TIME AND CLIMATE IN SOIL FORMATION}

Time.-This investigation has shown that the soils associated with the late Quaternary deposits are of several geologic ages, each fairly short, distinct, and separated by long intervals of negligible soil formation. Data on the absolute duration of the older soil optimums are not available, but the available stratigraphic and chronologic data suggest that the soil optimums were probably shorter than the intervals between them. For instance, no significant soil development took place during the time between the Cocoon and Churchill soil optimums, yet this interval-all of the Eetza and Wyemaha time-was certainly many thousands and probably several tens of thousands of years long. Likewise, 
the only appreciable weathering profile formed during the time between the Churchill and Toyeh optimums was the very weak Harmon School soil that formed during a brief optimum; yet according to Antevs' chronology (1955) the whole interval between Churchill and Toyeh may have been more than 20,000 years long. The Toyeh interval, in contrast, may have been only a few hundred years long (fig. 39). During the subsequent 3,500 years or so to the present, only the very weak L-Drain soil formed, within its optimum of perhaps several hundred years.

Many soil scientists consider that the total age of a soil (time elapsed since it started to form) is a true measure of time as a pedogenic factor. The inferences given above do not support this view. A simple demonstration that it is fallacious can be made by comparing buried and relict occurrences of the more strongly developed (Cocoon, Churchill, and Toyeh) soils; invariably the profiles are almost identical, showing that each soil formed during a definite limited interval of past time.

A corollary deduction is that the rate of soil-profile development has varied greatly. Soil development obviously was much more rapid during the soil-forming intervals than during the long intervening times. In view of the aridity of the Carson Desert area, it might be thought that the infrequency and brevity of the strong soil-forming intervals is purely local peculiarity. That this is not so is shown by the stratigraphically distinct soils, separated by deposits spanning long intervals of little or no soil formation, in a wide variety of other areas (such as the Sierra Nevada) that represent very different climatic environments.

Climate.-The absence of soils that are coeval with the lake intervals shows that the climate of these times, contemporaneous with glacial intervals in the Sierra Nevada and probably wetter and colder than now, was not conducive to soil development. The negligible soil formation in post-Toyeh time, when climate has fluctuated within a small range of present values (p. 106); Antevs, 1948, p. 179-182; 1952, p. 104-106), shows that the climate today is unlike that during which principal soils formed.

The strongest soils-Cocoon, Churchill, and Toyehformed during intervals that seem to have been somewhat warmer and wetter than now (p. 97, 100, 103). Though the actual temperature increases probably were only a few degrees above present mean annual temperature, their effects in increasing the rate of soil development seem to have been considerable. The fact that soil formation was negligible during the lake intervals indicates that higher temperature was more critical in increasing the rate of soil development than higher precipitation. This would explain why the stronger soils formed during the warmer desiccation intervals, which are correlated with interglacial stages (not with glacial stages, as Moss (1951, p. 40, 78) has suggested).

The general aridity of the Carson Desert illustrates the importance of moisture in soil formation. The lack of soil development during Wyemaha and Turupah times probably was due to the warm parts of these intervals being extremely arid, thus severely inhibiting chemical weathering processes. Apparently a certain moderate amount of moisture is needed for active soil formation to take place, but given this critical amount, further increase in moisture may be less of an accelerant of soil formation than increase in temperature. The dominance of temperature as a soil-forming factor explains why the soils are good time-stratigraphic markers, for climatologists recognize that temperature fluctuations are far more regular in geographic scope than precipitation changes.

\section{ECONOMIC GEOLOGY}

No commercial metalliferous deposits have been discovered within the map area. Small quantities of natural gas (methane) issue from many wells in the lowlands, but possibilities of commercial accumulations of either natural gas or petroleum seem remote. The principal economic mineral resources are sand, gravel, pumice, perlite, bentonite, diatomite, salt, borax, and soda.

\section{NATURAL GAS AND PETROLEUM}

Occurrences of natural gas.--Hydrocarbon-bearing natural gas issues from more than two dozen wells that have been drilled either for water or as test wells for oil and gas. These wells are in a northeastwardtrending belt 5 to 10 miles wide that extends from $11 / 2$ miles west of Carson Lake to about 10 miles northeast of Stillwater (pl.2). A few wells have estimated yields of several hundred cubic feet of gas per day, but most yield much less. Several of the better producers, located mostly near Stillwater, have in the past supplied gas for heating and cooking at nearby ranch houses, but in 1947-50 none were still in use.

Only some of the gas-producing wells yield inflammable gas, and even this seems to be considerably diluted by air. Methane is the principal hydrocarbon, although at least two wells yield small percentages of ethane and higher hydrocarbons (tables 8 and 9 ).

Most wells are less than 300 feet deep; their gas comes from highly organic sediments in the Wyemaha formation. Some of the deeper wells may derive gas from pre-Lake Lahontan Quaternary sediments, but 
there has been no production from pre-Quaternary rocks.

TABLE 8.-Combustion (Orsat type) analyses (in percent) of natural gas from two wells near stillwater, Nev.

[All samples collected by R. W. Richards and J. Hiram Smith, U.S. Geological Survey; laboratory sample number is in parentheses]

\begin{tabular}{|c|c|c|c|c|}
\hline \multirow{2}{*}{ Constituent or property } & \multicolumn{2}{|c|}{ Well 1} & \multicolumn{2}{|c|}{ Well 2} \\
\hline & $\mid \begin{array}{l}\text { Sample } A \\
\text { (B.M. 4192) }\end{array}$ & $\underset{(47-G-8)}{\text { Sample } B{ }^{1}}$ & $\underset{(47-G-5)}{\text { Sample } A}$ & $\underset{(47-G-7)}{\text { Sample } B}$ \\
\hline $\begin{array}{l}\text { Carbon dioxide } \\
\text { Methane }\left(\mathrm{CH}_{4}\right) \\
\text { Ethane }\left(\mathrm{C}_{2} \mathrm{H}_{6}\right) \text { and higher }\end{array}$ & $\begin{array}{r}0.8 \\
61.8\end{array}$ & $\begin{array}{r}1.65(1.65) \\
40.21(47.18)\end{array}$ & $\begin{array}{l}1.75 \\
6.48\end{array}$ & $\begin{array}{r}1.72 \\
12.08\end{array}$ \\
\hline $\begin{array}{l}\text { hydrocarbons. } \\
\text { Nitrogen (by difference) }\end{array}$ & $\begin{array}{r}1.4 \\
35.4\end{array}$ & $\begin{array}{l}15.88(10.45) \\
42,56(40.72)\end{array}$ & $\begin{array}{r}4.38 \\
87.39\end{array}$ & 84.91 \\
\hline $\begin{array}{l}\text { Oxygen } \\
\text { Specific gravity (air }=1 \text { ) } \\
\text { Btu (calculated) }\end{array}$ & $\begin{array}{c}0.6 \\
2651\end{array}$ & $\begin{array}{c}0 \\
0.824(0.789) \\
3689(663)\end{array}$ & $\begin{array}{c}0 \\
0.979 \\
158\end{array}$ & $\begin{aligned} 0.49 \\
137\end{aligned}$ \\
\hline
\end{tabular}

1 Recomputation by R. K. Bailey, U.S. Geological Survey, from original laboratory data (in parentbeses).

Btu per cubic foot of dry gas at $60^{\circ} \mathrm{F}$ and pressure of 30 inches of mercurg.

${ }^{3}$ Gross Btu at $60^{\circ} \mathrm{F}$ and pressure of $15.025 \mathrm{lbs}$ per square inch.

WELL 1.-Flowing well producing combustible gas, on the Elmer Weishaupt Ranch in sec. 1, T. 19 N., R. 30 E., near Stillwater, Nev. Two 1-gallon samples were collected by water displacement on November 27,1946 . Sample $A$ was analyzed in January 1946 by the U.S. Bureau of Mines Oil and Gas Laboratory, Amarillo Tex. Sample $B$ was analyzed January 3,1947 , by $J$. D. Clark, U.S. Geological Survey. This well was drilled about 1926 by Tex Reynolds of Fallon, to a depth of about 200 feet and cased to about 150 feet with 3 -inch casing. Water at about $88^{\circ} \mathrm{F}$ issues from the well and is used for domestic purposes at the Weishaupt

WELL 2.-At L. H. Greenwood store, Stillwater, Nev., 520 feet east and 600 feet north of the SW cor. sec. 7, T. 19 N., R. $3 \mathrm{l} \mathrm{E}$. Two 1-gallon samples were collected October 27, 1946. Sample $A$ was analyzed November 20, 1946; sample $B$ was analyzed January 20, 1947, both by . D. Clark or the U. S. Geological survey. This well was drilled in 1923 by Robert Coombs to a depth of 230 feet and cased to mor than 100 feet. It flows several gallons per minute. The water has a temperature of $190^{\circ} \mathrm{F}$, and it was used for heating the store in 1947. A noncombustible gas, taken from overnight radiator accumulation.

TABLE 9.-Analyses (in percent) of naturat gas from two wells 9 miles south of Fallon

\begin{tabular}{|c|c|c|c|}
\hline \multicolumn{2}{|l|}{ Well $\boldsymbol{A}$} & \multicolumn{2}{|l|}{ Well $B$} \\
\hline Constituent or property & $\begin{array}{l}\text { Percent } \\
\text { or value }\end{array}$ & Constituent or property & $\begin{array}{l}\text { Percent } \\
\text { or value }\end{array}$ \\
\hline & & Carbon dioxide. & \\
\hline $\begin{array}{l}\text { On air-free basis: } \\
\text { Carbon dioxide } \\
\text { Methane... }\end{array}$ & $\begin{array}{l}\text { 1. } 47 \\
98.31\end{array}$ & $\begin{array}{l}\text { Oxygen } \\
\text { Methane } \\
\text { Ethane and higher bydro- }\end{array}$ & $\begin{array}{r}.2 \\
97.0\end{array}$ \\
\hline Ethane & .22 & $\begin{array}{l}\text { carbons } \\
\text { Nitrogen and other inert gases }\end{array}$ & .0 \\
\hline $\begin{array}{l}\text { Propane and heavier by- } \\
\text { carbons. }\end{array}$ & Tr. & $\begin{array}{l}\text { (by difference). } \\
\text { Helium (by separate anal- } \\
\text { ysis). }\end{array}$ & $\begin{array}{l}2.1 \\
.001\end{array}$ \\
\hline $\begin{array}{l}\text { Specific gravity (calculated) } \\
\text { Btu (calculated) }\end{array}$ & $\begin{array}{l}0.569 \\
998\end{array}$ & $\begin{array}{l}\text { Specific gravity (calculated) } \\
\text { Btu (calculated) }\end{array}$ & 985 \\
\hline
\end{tabular}

1 Btu per cubic foot of dry gas at $60^{\circ} \mathrm{F}$. and pressure of 30 inches of mercury. NorE. - The wells are on the Jones and Jewell Ranch, one (well $A$ ) in the SE $3 / 4 \mathrm{EW} 14$, and the other (well $B$ ) in the SW1/4NW 1/4, of sec. 18, T. 17 N, R. 29 E. Both were drilled prior to 1908, well $A$ to a depth of 256 feet and well $B$ to a depth of 255 or 265 feet. Both flow several gallons a minute of slightly mineralized (sodium carbonate) water and produce several hundred cubic feet a day of combustible gas. The gas sample from well $A$ was collected July 1946 by J. S. Johnson of Fallon and analyzed A ugust 24, 1946, by Smith-Emery Co., Los Angeles. It probably was contaminated by air. The gas sample from well $B$ was collected November 27,1946 , by uary1947 by the U.S. Bureau of Mines Oil and Gas Laboratory, Amarillo, Tex

The first recognition of natural gas in the area was in 1865 , when an oil claim was filed on a gas seepage at Soda Lake. This seepage apparently now is inundated by the 55-foot rise of Soda Lake since development of the Newlands Reclamation Project. Two other reported former gas seeps, one in the SW1/4 sec. $27, \mathrm{~T} .19$ N., R. 28 E., and another in the SW1/4NW1/4 sec. 11, T.
18 N., R. 29 E., have been covered and lost because of field leveling.

Occurrence of petroleum.-In 1911-12, a 909-foot test well (Timber Lake well) was drilled for the U.S. Geological Survey in sec. 30, T. 21 N., R. 30 E., about 14 miles northeast of Fallon, as part of the program of exploration for potash in the basins of the arid southwest. The $\log$ of this well (Gale, 1913) mentions that oil spots were observed in the sludge water at five horizons. These horizons probably are of Wyemaha and (or) pre-Lake Lahontan Quaternary age. This is the only substantiated occurrence of petroleum in the area.

From 1919 to 1923 there was much excitement over the oil possibilities near Fallon. Several oil companies were promoted, and over a dozen test wells were drilled to depths ranging from a few hundred to 3,200 feet. Although some of these wells were alleged to have shows of oil, none of the reports have been substantiated, and most of them seem extremely unlikely. A few of the wells yielded minor amounts of gas. In later years repeated attempts were made by promoters to lease land for wildcat drilling, and since 1947 geologists of several leading oil companies have visited the area, but to 1958 no further drilling for oil or natural gas had been done.

The very small amounts and relatively low quality of the natural gas yielded by wells to date show that there is little chance of finding commercial accumulations of natural gas in the Quaternary fill. The possibilities of commercial supplies from the Tertiary and pre-Tertiary rocks of the area have not been adequately explored, but they are not encouraging.

\section{MINERAI DEPOSITS}

Metalliferous deposits.-The only known metalliferous deposits are in the southern half of Rainbow Mountain, where weakly metallized quartz veins occur locally along faults in the basalt and dacite of Rainbow Mountain. Several small prospect workings have explored these veins. They are reported to have encountered low values in silver and gold, but apparently nothing of workable grade; none of them have had any production.

Pumice.-Pumiceous tuff is fairly widespread in the Truckee formation, but little of it is sufficiently pure, of proper size grade, and of high enough compressive strength to be desirable for concrete aggregate. In the northern part of the saddle between Rainbow Mountain and Sehoo Mountain, however, is a deposit having excellent characteristics. This deposit was opened in 1951 by the Fallon Concrete Products Co. of Fallon and is the source of the pumice used by this concern for its pumice-concrete building blocks. 
LAKE LAHONTAN: GEOLOGY, CARSON DESERT, NEV.

Perlite.-The vitrophyric flows in the upper part of the Eagles House rhyolite in the southern part of the White Throne Mountains locally contain perlite of possible commercial utility. One deposit in the $\mathrm{SE} 1 / 4$ sec. 16, T. 16 N., R. 29 E., has recently been prospected on a small scale by the U.S. Gypsum Co. and is said to have material that expands well on heating.

Diatomite.-Diatomite occurs in the upper parts of the Truckee formation in several places, but most is of poor quality. One of the best deposits is in the northeastern part of the Desert Mountains, in secs. 23 and 24 (unsurveyed), T. 16 N., R. 29 E. The diatomite crops out along the hillsides and has been explored by several short adits, shallow prospect pits, trenches, and two drilled wells, one 60 and the other 80 feet deep. Two beds of nearly pure diatomite 8 feet or more thick are exposed, as well as several thinner beds of nearly pure and several of impure diatomite; the total exposed thickness of diatomite aggregates at least 30 feet. One of the wells cut 24 feet of diatomite and the other 30 feet. Only a small part of the deposit is available for surface mining, however, the remainder being deeply buried by higher beds of the Truckee formation and by lavas of the Bunejug formation.

Soda.-The highly saline waters of the two Soda Lakes, Big Soda Lake (or Soda Lake) and Little Soda Lake, have produced considerable amounts of sodium carbonate (or soda, mineralogically known as trona) in the past. Russell (1885) estimated that the water of Big Soda Lake held about 2 million tons of salts, including 428,000 tons of sodium carbonate, 342,000 tons of sodium sulfate, and 1,248,000 tons of sodium chloride.

Soda was discovered in Little Soda Lake in 1855 by Asa L. Kenyon. In 1868 Kenyon sold his claims at this lake to Higgins and Duffy, of San Francisco, Calif. The latter organized a company and began production of soda. A force of about 5 men prepared about 60 tons every month, which brought $\$ 55$ to $\$ 65$ a ton. This probably was the first important production of soda in the West.

Soda was produced from Big Soda Lake from 1875 to 1893. The combined annual yield from both lakes between 1868 and 1893 ranged between 300 and 800 tons of soda (Vandenburg, 1940, p. 43). The extraction process is described by Vandenburg (1940, p. 44-45). Since 1901, levels of both lakes have risen (about 55 feet at Soda Lake) because of general rise of the water table with development of the Newlands Reclamation Project, completely inundating the vats, machinery, and buildings formerly used for extracting the soda.

Borax.--In the part of Eightmile Flat adjoining the northeast tip of the Bunejug Mountains, are many saline seeps and small springs whose waters have im- pregnated the surrounding ground with borate minerals. The chief mineral is ulexite, a hydrous borate of sodium and calcium which commonly occurs in the form known as cotton balls.

According to Vandenburg (1940, p. 40, 41-42), the borax deposits were discovered in 1869 and were operated in 1870 and 1871 by the American Borax Co., at a capacity of about 1 ton a day. The material worked averaged about 10 percent borax, although some yielded as much as 30 percent. Production ceased in 1872 because of a drop in price.

In the late 1860's borax was discovered in the water of Big Soda Lake by William Troup. About 1869 Troup and associates attempted to produce borax from this lake but the venture failed.

Guano.-Several of the caves carved by Lake Lahontan have been worked for small deposits of bat guano. Most of these caves are on the north sides of Eetza Mountain (Picnic Cave, Hidden Cave, Fallen-in Cave, and Burnt Cave) and Sehoo Mountain (Fish Cave). Most of the extraction was done between 1930 and 1940 . The largest caves are said to have yielded a hundred cubic yards or more of guano apiece, which was used locally for high-grade fertilizer. The guano mining unfortunately destroyed most of the superb archeologic record that the caves formerly held.

Bentonite.-Much of the lake clay in the basin interior, particularly that in the Sehoo formation, consists largely of montmorillonite, the chief clay mineral in bentonite. Practically all the clay contains a high percentage of calcium, however, and is of low-swelling type. High-sodium clay with high-swelling properties-true bentonite-occurs locally along the east edge of the Hot Springs Mountains, and it may also be present in other areas where the ground water is highly sodic.

\section{CONSTRUCTION MATERIALS}

Sand and gravel.-Many deposits of sand and gravel have been worked for road metal, concrete aggregate, and similar uses, but most are small. The best gravel deposits are the lowest gravel spits and bars of Lake Lahontan near the edges of the mountains. The largest within the map area are the embankments. along the north front of the Desert Mountains and the spit that extends more than 2 miles southward from the southwest edge of the Bunejug Mountains, but these have not yet been worked. Lesser deposits include the following: a spit at the northwest tip of the Bunejug Mountains, which has been worked intermittently for gravel by the Dodge Construction Co. of Fallon; spits at the north edge of these mountains; bars in the sadle at the west end of Wyemaha Valley, which furnished many thousands of cubic yards of fill for runways at 
the Fallon Naval Air Station in 1952; and a spit at the northwest edge of the White Throne Mountains, where a gravel pit operated by the Nevada State Highway Department is located.

Workable deposits of clean coarse sand are confined mainly to ancient delta or chanel deposits of the Carson River. A delta deposit of the upper member of the Sehoo formation in the NW1/4 sec. 26, T. 19 N., R. 28 E., was being worked in 1950-51 for sand for concrete blocks by the Fallon Concrete Products Co. Several small sand pits also have been opened in alluvial sand of the Turupah formation a few miles southeast of Fallon.

\section{GROUND WATER}

The Carson Desert area is generally unfavorable for large supplies of subsurface water of good quality. Springs are few and small, wells generally have small yields, and much of the water is highly mineralized.

Springs.-All the springs and large seeps seem to be situated at faults, and hence are probably artesian. Four small springs, yielding a fraction of a gallon per minute of slightly brackish water, are located along the Wildcat fault zone: 2 in sec. 17, T. 17 N., R. 30 E., 1 in sec. 29 of this township, and another in sec. 4, T. 16 N., R. 29 E. Three springs are situated along the fault zone that bounds Eightmile Flat on the south: the 2 "Rock Springs" and another half a mile to the southwest. The water is too brackish for human consumption but can be drunk by animals. Near the west edge of Eightmile Flat are several seeps and very small springs that yield highly saline water.

The interior of the Carson Desert is practically devoid of springs. Small springs of potable water, yielding less than 1 gallon per minute, occur about 1 mile northwest of Papoose Lake and 2 miles west of the southern part of Upsal Hogback.

Wells.-Wells are largely confined to the farming area. Even the better ones have relatively small yields, adequate for domestic and stock use but not for extensive irrigation. Stringers of alluvial sand and gravelly sand of post-Sehoo channels of the Carson River locally furnish small supplies to shallow wells, but such water is liable to pollution. Near the Carson River these channel sands generally have water of better chemical quality than the deeper ground water.

The principal aquifer throughout the basin interior is the Wyemaha formation, and the yields and quality of the water vary with facies changes in this formation. The most copious yields and those of the best quality are obtained within a few miles of the Carson River west of Fallon, where the Wyemaha contains many stringers of gravel and sandy gravel. Farther in the interior of the basin moderate yields of fair quality com- monly are obtained from beds of lake sand in the upper part of this formation, but locally the only water either has a strong hydrogen sulfide or organic odor, or it is too saline to be potable. In some parts of the basin, notably near Carson Lake and Stillwater Slough, the Wyemaha formation is mostly silt and clay, yields little or no water, and the water generally is highly saline. Many of the wells that are deeper than 100 feet flow at the surface, yielding a fraction of a gallon to several gallons per minute.

Only small supplies have been obtained from the deeper Quaternary fill and commonly the water is highly mineralized. The wells from which the city of Fallon obtains its water (for example, well 19L, table 12) are exceptions : they derive their water from basalt that may correlate with the basalt of Rattlesnake Hill. Their water is remarkably low in salt content for deep ground water in the interior of the basin.

Several of the deepest flowing wells near Stillwater yield hot water. The well at Greenwood's store has a temperature of $190^{\circ} \mathrm{F}$ and was formerly used for heating the store. This well is only about 230 feet deep, hence the high temperature of the water probably is due to artesian flow from much greater depth along faults into the aquifers which supply the well. This part of the basin is believed to have had recurrent Quaternary faulting.

Several decades ago, a well drilled at the site of an extinct hot spring 3 miles northeast of Soda Lake encountered so much steam that drilling was stopped at a depth of about 60 feet; the well still furnishes steam for a bathhouse.

Although scarcely utilized at present, the natural hot water and steam obtainable from wells in these thermal areas are a potential industrial resource.

\section{SELECTED BIBLIOGRAPHY}

American Commission on Stratigraphic Nomenclature, 1952, Report 2-Nature, usage, and nomenclature of time-stratigraphic and geologic-time units: Am. Assoc. Petroleum Geologists Bull., v. 36, no. 8, p. 1627-1638.

-1956, Report 4-Nature, usage, and nomenclature of rock-stratigraphic units: Am. Assoc. Petroleum Geologists Bull., v. 40, no. 8, p. 2003-2014.

Anters, Ernst, 1925a, On the Pleistocene history of the Great Basin, in Quaternary climates: Carnegie Inst. Washington Pub. 352, p. 51-144.

1925b, The Big Tree as a climatic measure, in Quaternary climates: Carnegie Inst. Washington Pub. 352, p. 115-153.

1934, Climaxes of the last glaciation in North America : Am. Jour. Sci., 5th ser., v. 28, no. 166, p. 304-311; [abs.] ; Geol. Soc. America Proc. 1933, p. 449-450, June 1934.

1938a, Postpluvial climatic variations in the southwest: Am. Meteorol. Soc. Bull., v. 19, no 5, p. 190-193. 
Antevs, Ernst, 1938b, Rainfall and tree growth in the Great Basin: Carnegie Inst. Washington Pub. 469 ; Am. Geog. Soc. Spec. Pub. 21.

1945, Correlation of Wisconsin glacial maxima: Am Jour. Sci., v. 243-A, Daly volume, p. 1-39.

1948, Climatic changes and pre-white man, in The Great Basin, with emphasis on glacial and postglacial times: Utah Univ. Bull., v. 38, no. 20 (Biol. Ser., v. 10, no. 7), p. 168-191. 1952, Cenozoic climates of the Great Basin: Geologische Rundschau, v. 40, no. 1, p. 94-108.

1954, Climate of New Mexico during the last glaciopluvial. Jour. Geology, v. 62, no. 2, p. 182-191.

1955, Geologic-climatic dating in the west: Am. Antiquity, v. 20, no. 4, p. 317-335.

Axelrod, D. I., 1950, Studies in late Tertiary paleobotany: Carnegie Inst. Washington Pub. 590, 323 p.

Becker, G. F., 1882, Geology of the Comstock Lode and the Washoe district: U.S. Geol. Survey Mon. 3.

Billings, W. D., 1945, The plant associations of the Carson Desert region, western Nevada: Butler Univ. Bot. Studies, v. 7, p. 1-35.

1949, The shadscale vegetation zone of Nevada and eastern California in relation to climate and soils: Am. Midland Naturalist, v. 42, p. 87-109.

1951, Vegetational zonation in the Great Basin of western North America : Union internat. Sciences biol., Comptes Rendus des Colloque sur les bases ecologiques de la regeneration de la vegetation des zones arides.

Bissell, H. J., 1952, Stratigraphy of Lake Bonneville and associated Quaternary deposits in Utah Valley, Utah [abs.]: Geol. Soc. America Bull., v. 63, no. 12, pt. 2, p. 1358.

-1963 , Lake Bonneville: Geology of southern Utah Valley. Utah : U.S. Geol. Survey Prof. Paper, 257-B, p. 101-130.

Blackwelder, Eliot, 1928, Evidence of a third glacial epoch in the Sierra Nevada [abs.]: Geol. Soc. America Bull., v. 39, p. 268.

- 1929, Glacial history of the east side of the Sierra Nevada [abs.] : Geol. Soc. America Bull., v. 40, p. 127. 1931, Pleistocene glaciation of the Sierra Nevada and Basin ranges: Geol. Soc. America Bull., v. 42, p. 865-922. 1934a, Supplementary notes on Pleistocene glaciation in the Great Basin: Washington Acad. Sci. Jour., v. 24, p. 217-222.

1934b, Origin of the Colorado River: Geol. Soc. America Bull., v. 45 , no. 3, p. 551-566.

Bradley, W. H., 1929, Algal reefs and oolites of the Green River formation: U.S. Geol. Survey Prof. Paper 154, p. 203-223.

Bryan, Kirk, 1928, Glacial climate in nonglaciated regions: Am. Jour. Sci., v. 16, p. 162-164.

Bryan, Kirk, and Albritton, C. C., 1943, Soil phenomena as evidence of climatic changes: Am. Jour. Sci., v. 241, p. 469-490.

Byerly, Perry, 1956, The Fallon-Stillwater earthquakes of July 6, 1954, and August 23, 1954, Historical introduction: Seismol. Soc. America Bull., v. 46, no. 1, p. 1-3.

Calkins, F. C., 1944, Outline of the geology of the Comstock Lode District, Nevada : U.S. Geol. Survey open-file rept., 35 p.; accompanied by a $1: 24,000$-scale geologic map by F. C. Calkins and T. P. Thayer, 1945.

Call, R. E., 1884, On the Quaternary and Recent Mollusca of the Great Basin, with descriptions of new forms, introduced by a sketch of the Quaternary lakes of the Great Basin, by G. K. Gilbert: U.S. Geol. Survey Bull. 11, 66 p., 6 pls.
Chaney, R. W., 1938, Ancient forests of Oregon : A study of earth history in western North America: Carnegie Inst. Washington Pub. 501, p. 631-648.

Cloud, W. K., 1956, Intensity distribution and strong-motion seismograph results, Nevada earthquakes of July 6, 1954, and August 23, 1954: Seismol. Soc. America, v. 46, no. 1, p. 34-40.

Committee on Stratigraphic Nomenclature, 1933, Classification and nomenclature of rock units: Geol. Soc. America Bull., v. 44 , p. $423-459$.

Cope, E. D., 1883, On the fishes of the Recent and Pliocene lakes of the western part of the Great Basin, and of the Idaho Pliocene lake: Acad. Nat. Sci. Philadelphia Proc. 1883, p. 134-166.

Cressman, L. S., 1942, Archeological researchers in the northern Great Basin [written with the collaboration of F. C. Baker, H. P. Hansen, P. S. Conger, R. F. Heizer] : Carnegie Inst. Washington Pub. 538, v. 17, 158 p. (87 pls. incl. index, geol. relief maps).

Dana, E. S., 1884, A crystallographic study of the thinolite of Lake Lahontan: U.S. Geol. Survey Bull. 12, 34 p., 3 pls.

Davis, W. M., 1903, The mountain ranges of the Great Basin: Harvard Coll. Mus. Comp. Zoology Bull., v. 42 (1903-05), p. 129-177; reprinted in Geog. Essays, p. 725-772, 1909 (Ginn and Co., Boston) and 1954 (Dover Pubs.).

1925, The Basin Range problem: Nat'l Acad. Sci. Proc., v. 11, p. 387-393.

Deevey, E. S. Jr., 1949, Biogeography of the Pleistocene, pt. 1Europe and North America, [chap.] 3 of Flint, R. F., chm., Pleistocene research; a review by the Committee on Interrelations of Pleistocene Research. National Research Council : Geol. Soc. America Bull., v. 60, no. 9, p. 1315-1416.

1953, Paleolimnology and climate, [chap.] 22 of Shapley, H., ed., Climatic change: Cambridge, Harvard Univ. Press, p. 273-318.

Durrant, S. D., 1952, Mammals of Utah: Kansas Univ. Mus. Nat. History Pub., v. 6, 549 p.

Eardley, A. J., Gvosdetsky, Vasyl, and Marsell, R. E., 1957, Hydrology of Lake Bonneville and sediments and soils of its basin: Geol. Soc. America Bull., v. 68, no. 9, p. 11411202.

Emiliani, Cesare, 1955, Pleistocene temperatures : Jour. Geology, v. 63, no. 6, p. 538-578.

Englemann, Henry, 1876, Report on the geology of the country between Fort Leavenworth, K. T., and the Sierra Nevada near Carson Valley, in Simpson, J. H., Report of explorations across the Great Basin of the Territory of Utah: Washington, Engineering Dept., U.S. Army, p. 243-336.

Fenton, C. L. 1943, PreCambrian and early Paleozoic algae: Am. Midland Naturalist, v. 30, p. 83-111.

Ferguson, H. G., 1926, Later Tertiary and Pleistocene faulting in western Nevada [abs.]: Geol. Soc. America Bull. v. 37, p. 164

Ferguson,.H. G., and Cathcart, S. H., 1924, Major structural features of some western Nevada ranges: Washington Acad. Sci. Jour., v. 14, no. 15, p. 377.

Ferguson, H. G., Muller, S. W., and Cathcart, S. H., 1953, Geology of the Coaldale quadrangle, Nevada: U.S. Geol. Survey Geol. Quad. Map GQ-23.

1954, Geology of the Mina quadrangle, Nevada: U.S. Geol. Survey Geol. Quad. Map GQ-45.

Ferguson, H. G., Muller, S. W., and Roberts, R. J., 1951, Geology of the Winnemucea quadrangle, Nevada: U.S. Geol. Survey Geol. Quad. Map GQ-11. 
1951, Geology of the Mount Moses quadrangle, Nevada : U.S. Geol. Survey Geol. Quad. Map GQ-12.

Ferguson, H. G., Roberts, R. J., and Muller, S. W., 1952, Geology of the Golconda quadrangle, Nevada: U.S. Geol. Survey Geol. Quad. Map GQ-15.

Flint, R. F., 1947, Glacial geology and the Pleistocene epoch: New York, John Wiley and Sons, $589 \mathrm{p}$.

Free, E. E., 1914, The topographic features of the desert basins of the United States with reference to the possibilities of occurrence of potash: U.S. Dept. Agriculture Bull. 54 .

Fremont, J. C., 1845, Report of the exploring expedition to the Rocky Mountains in the year 1842, and to Oregon and North California in the years 1843-44: U.S. 28th Cong., 2d sess., House Exec. Doc. 166.

Gale, H. S., 1913, The search for potash in the desert basin region: U.S. Geol. Survey Bull. 530.

1914, Notes on the Quaternary lakes of the Great Basin, with special reference to the deposition of potash and other salines; U.S. Geol. Survey Bull. 540-N, p. 399-406.

1915, Geologic history of Lake Lahontan: Science, new ser., v. 41, p. 209-211.

Gianella, V. P., 1936, Geology of the Silver City district and the southern portion of the Comstock Lode, Nevada: Nevada Univ. Bull., v. 30, no. 9, 1936.

_ 1937, Glacial deposits in the Reno-Tahoe region [abs.] : Geol. Soc. America, Proc. 1936, p. 342.

Gianella, V. P., and Callaghan, Eugene, 1934, The earthquake of December 20, 1932, at Cedar Mountain, Nevada, and its bearing on the genesis of Basin Range structure: Jour. Geology, v. 42, no. 1, p. 1-22.

Gilbert, G. K., 1874, Preliminary geologic report, expedition of 1872 : U.S. Geol. and Geog. Surveys West of 100th Meridian Rept. (Wheeler), p. 48-52.

- 1875, Report on the geology of portions of Nevada, Utah, California, and Arizona : U.S. Geol. and Geog. Surveys West of 100th Meridian Rept. (Wheeler), v. 3, p. 17-187.

1890, Lake Bonneville: U.S. Geol. Survey Mon. 1.

1928, Studies of Basin Range structure: U.S. Geol. Survey Prof. Paper 153.

Grosscup, G. R., 1956, The archeology of the Carson Sink area : California Univ. [Berkeley] Archeol. Survey Rept. 33 (Papers on California archeology, no. 43), p. 58-64.

Hague, Arnold, and Emmons, S. F., 1877, Descriptive geology : U.S. Geol. Explor., 40th Parallel (King), v. 2.

Hance, J. H., 1914, Potash in western saline deposits: U.S. Geol. Survey Bull. 540, p. 457-469.

Hardman, George, and Mason, H. G., 1949, Irrigated lands of Nevada: Nevada Univ. Agriculture Expt. Sta. Bull. no. 183, Aug. 1949.

Hardman, George, and Venstrom, Cruz, 1941, A one-hundred year record of Truckee River runoff estimated from changes in levels and volumes of Pyramid and Winnemucca lakes: Am. Geophys. Union Trans., v. 22, pt. 1A, p. 71-90.

Heizer, R. F., 1951, Preliminary report on the Leonard rockshelter site, Pershing County, Nevada: Am. Antiquity, v. 17, no. 2.

- 1956, Recent cave explorations in the Lower Humboldt Valley, Nevada: California Univ. [Berkeley] Archeol. Survey Rept. 33 (papers on California archeology, no. 42), p. 50-57.

Heizer, R. F., and Krieger, A. D., 1956, The archeology of Humboldt Cave, Churchill County, Nevada: California Univ. [Berkeley] Pub., in Am. Archeology and Ethnology, v. 47, no. 1 .
Hubbs, C. L., and Miller, R. R., 1948, The zoological evidenceCorrelation between fish distribution and hydrographic history in the desert basins of the western United States, in The Great Basin, with emphasis on glacial and postglacial times: Utah Univ. Bull., v. 38, no. 20, p. 18-166.

Hunt, C. B., 1953, Pleistocene-Recent beundary in the Rocky Mountains region: U.S. Geol. Survey Bull. 996-A, p. 1-25.

Hunt, C. B., and Sokoloff, V. P., 1950, Pre-Wisconsin soil in the Rocky Mountain region, a progress report: U.S. Geol. Survey Prof. Paper 221-G, p. 109-123.

Hunt, C. B., Varnes, H. D., and Thomas, H. E., 1953, Lake Bonneville: Geology of northern Utah Valley, Utah; U.S. Geol. Survey Prof. Paper 257-A, p. 1-99.

Huntington, Ellsworth, 1914, The climatic factor as illustrated in arid America: Carnegie Inst. Washington Pub. 192, $341 \mathrm{p}$.

Hutchinson, G. E., 1937, A contribution to the limnology of arid regions, primarily founded on observations made in the Lahontan Basin: Connecticut Acad. Arts Sci. Trans., v. 33, p. 47-132.

Ives, R. L., 1951, Pleistocene valley sediments of the Dugway area, Utah: Geol. Soc. America Bull., v. 62, no. 7, p. 781797.

Jenney, C. P., 1935, Geology of the central Humboldt Range, Nev. : Nevada Univ. Bull., v. 29, no. 6, 73 p.

Jones, D. J., and Marsell, R. E., 1952, Pleistocene lake sediments in the vicinity of Salt Lake City, Utah [abs.]: Geol. Soc. America Bull., v. 63, no. 12, pt. 2, p. 1364.

1955, Pleistocene sediments of lower Jordan Valley, Utah, in Utah Geol. Soc. Guidebook 10, Tertiary and Quaternary history of the eastern Bonneville basin: p. 85-112.

Jones, J. C., 1914, The geologic history of Lake Lahontan: Science, v. 40, p. 827-830.

- 1925, The geologic history of Lake Lahontan, in Quaternary climates: Carnegie Inst. Washington Pub. 352, p. 1-50.

1929, Age of Lake Lahontan: Geol. Soc. America Bull., v. 40 , no. 3 , p. $533-540$.

1933, Itinerary, Reno to Pyramid Lake and return: Internat. Geol. Cong., 16th, Washington, D.C., 1933, Guidebook 16, Excursion C-1, Middle California and western Nevada, p. 102-108, pls. 14 and 16.

Jones, J. C., and Gianella, V. P., 1933 Reno and vicinity : Internat. Geol. Cong., 16th, Washington, D.C.,1933, Guidebook 16, Excursion C-1, Middle California and western Nevada, p. 96-102.

Kellogg, C. E., 1936, Development and significance of the great soil groups of the United States: U.S. Dept. of Agriculture Misc. Pub. 229.

Kern, E. M., 1859 [1876] [Journal of E. M. Kern of an exploration of Mary's or Humboldt River, Carson Lake, and Owens River and Lake in 1845], Appendix Q of Simpson, Capt. J. H., Explorations across the Great Basin of Utah : Washington, Engineering Dept., U.S. Army.

Kesseli, J. E., 1941, Studies in the Pleistocene glaciation of the Sierra Nevada, Calif.; 1, Topographic map of the Pleistocene glacial deposits in the Mammoth embayment, Mono County; 2, Changes in the courses of some Pleistocene glaciers and their relation to interglaciation: California Univ. Pub. Geography, v. 6, no. 8, p. 315-362.

King, Clarence, 1878, Systematic geology: U.S. Geol. Explor., 40th Parallel (King), v. 1, 803 p.

Knopf, Adolph, 1918, Geology and ore deposits of the Yerington district, Nevada: U.S. Geol. Survey Prof. Paper 114, 68 p. 
Knopf, Adolph, 1924, Geology and ore deposits of the Rochester district, Nevada : U.S. Geol. Survey Bull. 762, 78 p.

Krumbein, W. C., and Sloss, L. L., 1951, Stratigraphy and sed1mentation: San Francisco, W. H. Freeman and Co., 497 p.

Lapham, M. H., 1932, Genesis and morphology of the desert soils: Am. Soil Survey Assoc., rept. of 12th Ann. Meeting, Bull. 13, p. 34-52.

LeConte, Joseph, 1889, On the origin of normal faults and of the structure of the Basin region: Am. Jour. Sci., 3d. ser., v. 38, p. 251-263.

Lee, W. T., and others, 1915, The Overland Route, with a side trip to Yellowstone Park, pt. B of Guidebook of the western United States: U.S. Geol. Survey Bull. 612, 244 p.

Loud, L. L., and Harrington, M. R., 1929, Lovelock Cave: California Univ. Pub., in Am. Archeology and Ethnology, v. $25: 1$.

Louderback, G. D., 1904, Basin Range structure of the Humboldt region: Geol. Soc. America Bull., v. 15, p. 289-346.

1923, Basin Range structure in the Great Basin: California Univ. Dept. Geol. Sci. Bull., v. 14, no. 10, p. 329-376.

MacDonald, J. R., 1950, A note on the age of the Truckee formation : Am. Jour. Sci., v. 248, p. 581-583.

Marsell, R. E., and Jones, D. J., 1955, Pleistocene history of lower Jordan Valley, Utah, in Utah Geol. Soc. Guidebook 10, Tertiary and Quaternary geology of the eastern Bonneville basin : p. 113-120.

Matthes, F. E., 1925, Evidences of recurrent glaciation in the Sierra Nevada of California: Science, new ser., v. 61, p. $550-551$.

1930, Geologic history of the Yosemite Valley: U.S. Geol. Survey Prof. Paper 160.

1942, Glaciers, in Meinzer, O. E., ed., Physics of the earth, pt. 9, Hydrology: New York, McGraw-Hill Book Co., p. 149-219.

McGee, W J, 1889, An obsidian implement from Pleistocene deposits in Nevada: Am. Anthropologist, v. 2, p. 301-312.

Meinzer, O. E., 1922, Map of the Pleistocene lakes of the Basin and Range province and its significance: Geol. Soc. America Bull., v. 33, p. 541-552.

Merriam, J. C., 1917, An occurrence of mammalian remains in a Pleistocene lake deposit at Astor Pass, near Pyramid Lake, Nevada: California Univ. Dept. Geol. Sci. Bull., v. 8 , no. 21 .

1919, Evidence of mammalian paleontology relating to the age of Lake Lahontan: California Univ. Dept. Geol. Sci. Bull., v. 10, no. 25.

Miller, R. R., 1946, Correlation between fish distribution and Pleistocene hydrography in eastern California and southwestern Nevada, with a map of the Pleistocene waters: Jour. Geology, v. 54, p. 43-53.

Morrison, R. B., 1952a, Stratigraphy of Lake Lahontan and associated Quaternary deposits in the Carson Desert area, near Fallon, Nevada [abs.] : Geol. Soc. America Bull., v. 63, no. 12, pt. 2, p. 1367.

- 1952b, Late Quaternary climatic history of the northern Great Basin [abs.]: Geol. Soc. America Bull., v. 63, no. 12 , pt. 2 , p. 1367.

- 1958a, Stratigraphic sections, auger-hole logs, soilprofile sections, and driller's logs of wells drilled for water, oil, and natural gas in the southern Carson Desert area, near Fallon, Nevada; U.S. Geol. Survey open-flle rept.
$1958 \mathrm{~b}$, Late Quaternary stratigraphy of the southern Carson Desert (Fallon) area [abs.], in Problems of the Lake Lahontan Basin-a symposium : Nevada Univ., p. 4-7. -1958c, Geology of Hidden Cave, near Fallon, Nevada, in Great Basin Archeol. Conf., 5th, Nevada Univ., Abstracts (mimeo.).

1961a, Lake Lahontan stratigraphy and history in the southern Carson Desert (Fallon) area, Nevada, in Short papers in the geologic and hydrologic sciences: U.S. Geol. Survey Prof. Paper 424-D, p. D111-D114.

1961b, New evidence on the history of Lake Bonneville from an area south of Salt Lake City, Utah: U.S. Geol. Survey Prof. Paper 424-D, p. D125-D127.

1961c, Correlation of the deposits of Lakes Lahontan and Bonneville and the glacial sequences of the Sierra Nevada and Wasatch Mountains, California, Nevada, and Utah: U.S. Geol. Survey Prof. Paper 424-D, p. D122-D124. 1961d, A suggested Pleistocene-Recent (Holocene) boundary for the Great Basin region, Nevada-Utah: U.S. Geol. Survey Prof. Paper 242-D, p. D115-D116.

Morrison, R. B., Gilluly, James, Richmond, G. M., and Hunt, C. B., 1957, In behalf of the Recent: Am. Jour. Sci., v. 225, p. $385-393$.

Moss, J. H., 1951, Early man in the Eden Valley [Wyo.]: Philadelphia, Pennsylvania Univ. Mus. Mon., 124 p.

Muller, S. W., Ferguson, H. G., and Roberts, R. J., 1951, Geology of the Mount Tobin quadrangle, Nevada: U.S. Geol. Survey Geol. Quad. Map GQ-7.

Nikiforoff, C. C., 1941, Morphological classification of soil structure : Soil Sci., v. 52, no. 3.

Nolan, T. B., 1943, The Basin and Range province in Utah, Nevada, and Califorrata: U.S. Geol. Survey Prof. Paper 197-D, p. 141-196.

Orr, P. C., 1956, Pleistocene man in Fishbone Cave, Pershing County, Nevada: Nevada State Mus. Dept. Archeology Bull. $2,20 \mathrm{p}$.

Phalen, W. C., 1913, Potash salts, summary for 1912 : U.S. Geol. Survey Mineral Resources U.S., 1912, pt. 2, p. 880-882.

Putnam, W. C., 1949, Quaternary geology of the June Lake District, California: Geol. Soc. America Bull., v. 60, p. 12811302 .

1950, Moraine and shoreline relationships at Mono Lake, California: Geol. Soc. America Bull., v. 61, no. 2, p. 115-122.

Rezak, Richard, 1956, Precambrian algae and stromatolites [abs.] in Resumenes de los Trabajos Presentados: Internat. Geol. Cong., 20th, Mexico City 1956, p. 124.

Richmond, G. M., 1950, Interstadial soils as passible stratigraphic horizons in Wisconsin chronology [abs.] : Geol. Soc. America Bull., v. 61, no. 12, pt. 2, p. 1497.

1962, Quaternary stratigraphy of the La Sal Mountains, Utah : U.S. Geol. Survey Prof. Paper 324, 135 p.

Richmond, G. M., and Frye, J. C., 1957, Status of soils in stratigraphic nomenclature [Note 19 for Am. Comm. on Strat. Nomenclature] : Am. Assoc. Petroleum Geologists Bull., v. 41 , no. 4 , p. $758-763$.

Robinson, T. W., and Fredericks, J. C., 1946, Groundwater in Lovelock Valley, Nevada: Nevada Water Resources Bull. 2 , issued by the Office of the State Engineer.

Russell, I. C., 1884, A geological reconnaissance in southern Oregon: U.S. Geol. Survey 4th Ann. Rept., p. 435-464.

1885, Geological history of Lake Lahontan, a Quaternary Lake of northwestern Nevada: U.S. Geol. Survey Mon. 11. 
1889, Quaternary history of Mono Valley, California; U.S. Geol. Survey 8th Ann. Rept., p. 261-394.

1895b, Present and extinct lakes of Nevada: Natl. Geog. Soc. Mon. 1, no. 4, p. 101-136; also in National Geographic Society, 1896, The physiography of the United States: New York, American Book Co., p. 101-136.

Schrader, F. C., 1947, Geology and ore deposits of the Carson Sink quadrangle, Nevada : U.S. Geol. Survey open-file rept.

Schultz, C. B., Lueninghoener, G. C., and Frankforter, W. D., 1951, A graphic résumé of the Pleistocene of Nebraska (with notes on the fossil mammalian remains): Nebraska Univ. State Mus. Bull., v. 3, no. 6, 41 p.

Seismological Society of America, 1954, Seismological notes, Fallon, Nevada, July 6, 1954 : Seismol. Soc. America Bull., v. 44, p. $620-621$.

Sharp, R. P., 1939, The Miocene Humboldt formation in northeastern Nevada : Jour. Geology, v. 47, no. 2, p. 133-160.

Simpson, J. H., 1876, Explorations across the Great Basin of the Territory of Utah: Washington, Engineering Dept., U.S. Army.

Slemmons, D: B., 1956, Geologic setting for the Fallon-Stillwater earthquakes of 1954: Seismol. Soc. America Bull., v. 46, no. 1, p. 4-9.

Smith, H. T. U., 1946, Sand dunes : New York Acad. Sci. Trans., sec. 2 , v. 8, no. 6, p. 197-199.

- 1953, Classification of sand dunes [abs.] in Capot-Rey, R., ed., Deserts actuels et anciens : Internat. Geol. Cong., 19th, Algiers 1953, Comptes rendus, sec. 7, pt. 7, p. 105.

Spurr, J. E., 1901, Origin and structure of the Basin ranges: Geol. Soc. America Bull., v. 12, p. 217-270.

1903, Descriptive geology of Nevada south of the 40th parallel and adjacent portions of California: U.S. Geol. Survey Bull. 208.

Stanley, G. M., 1949, Elevations of some Lake Lahontan shorelines [abs.] : Geol. Soc. America Bull., v. 60, p. 1945.

Steinbrugge, K. V., and Moran, D. F., 1956, Damage caused by the earthquakes of July 6, and August 23, 1954: Seismol. Soc. America Bull., v. 46, no. 1, p. 15-33.

Strahorn, A. T., and Van Duyne, Cornelius, 1912, Soil Survey of the Fallon area, Nevada: U.S. Dept. Agriculture, Field Operations of Bur. Soils, 1909, p. 1477-1516.

Thayer, T .P., 1937, Petrology of later Tertiary and Quaternary rocks of the north-central Cascade Mountains in Oregon, with notes on similar rocks in western Nevada: Geol. Soc. America Bull., v. 48, p. 1648-1650.

Thompson, G. A., 1952, Basin and Range structure south of Reno, Nevada [abs.]: Geol. Soc. America Bull., v. 63, p. 1303.

- 1956, Geology of the Virginia City quadrangle, Nevada: U.S. Geol. Survey Bull. 1042-C, p. 45-75.

Tocher, Don, 1956, Movement on the Rainbow Mountain fault : Seismol. Soc. America Bull., v. 46, no. 1, p. 10-14.

U.S. Department of Agriculture, 1941, Climate and man: U.S. Dept. Agriculture Yearbook.

— 1951, Soil survey manual (revised ed.) : U.S. Dept. Agriculture, Agriculture Handbk. 18, 503 p.

U.S. Reclamation Service, 1903-05, Township topographic maps of the Truckee-Carson Project: U.S. Reclamation Service Hydrog. Br. (formerly under U.S. Geol. Survey, now U.S. Bur. Reclamation).
Van Winkle, Walton, 1914, Quality of the surface waters of Oregon : U.S. Geol. Survey Water-Supply Paper 363, 137 p.

Vandenburg, W. O., 1940, Reconnaissance of mining districts in Churchill County, Nev. : U.S. Bur. Mines Inf. Circ. 7093.

Wilmarth, M. G., 1938, Lexicon of geologic names of the United States (including Alaska) : U.S. Geol. Survey Bull. 896, pts. 1 and 2.

Yen, Teng-chien, 1950, A molluscan fauna from the type section of the Truckee formation: Am. Jour. Sci., v. 248, p. 180-183.

\section{STRATIGRAPHIC SECTIONS, SOIL-PROFILE SECTIONS, AND WELL LOGS}

TABLE 10.-Stratigraphic sections in the southern Carson
Desert area

Section 1

Sec. 15, T. 21 N., R. 30 E. Exposed by trenching scarp of large deflation basin; altitude $3,880 \pm 5$ feet.

Fallon formation: Sand, lake and eolian ..... Disconformity: erosion surface.

Sehoo formation:

Lower member:

1. Clay, olive-green-gray. Lacustrine

2. Sand, fine, rust-brown, locally indurated. Lacustrine ..... -

3. Clay, olive-green-gray, ostracodes disseminated and in 1/16 in.-thick lenses of fine sand; slightly laminated locally. Lacustrine...................

4. Ash, volcanic, white, silt-sized. Lacustrine

5. Clay, similar to $3 \ldots \ldots$

6. Sand, fine, rust-brown, abundant ostracodes. Lacustrine.-

7. Clay, similar to $3 ; 1 / 8$ in. white volcanic ash parting about $1.5 \mathrm{ft}$ below top. Lacustrine . -

Base not exposed.

$\begin{array}{cl}\text { Thickness } & \begin{array}{l}\text { Depth } \\ (\text { feet })\end{array} \\ 2 \pm & 2 \pm\end{array}$

$2 \pm \quad 2 \pm$

$6 \pm \quad 8 \pm$

$.2 \pm \quad 8.2 \pm$

$2 \pm \quad 10.2 \pm$

$.1 \pm \quad 10.3 \pm$

$1 \pm \quad 11.3 \pm$

$.15 \quad 11.5 \pm$

3. $5 \pm \quad 15.0 \pm$

Section 2

600 feet south of $N W$ cor. sec. 21, T. 21 N., R. $29 E$. Auger hole at south edge of playa embayment southwest of Carson Sink; altitude $3,888 \pm 3$ feet.

Fallon formation: $\begin{array}{cc}\text { Thickness } & \text { Depth } \\ (\text { feet }) & \text { feet })\end{array}$

Upper member:

Clay, silty, saline, light-gray. Discontinuous lag gravel on surface: fragments of tan lithoid tufa (basininterior lithoid tufa of lower member of Sehoo formation). Lacustrine.

Disconformity.

Wyemaha formation:

Sand, medium, well-sorted, deep-rustyyellow in upper part, downward more and more gray. Somewhat limoniteand calcium carbonate-cemented in upper few inches. Lacustrine......... 
TABLE 10.-Stratigraphic sections-Continued Section 2-Continued

Wyemaha formation-Continued

Sand, medium, some coarse sand and grit somewhat silty and clayey; many dark basaltic or andesitic granules; dark Thicknes
$($ feet $)$

Depth
(feet) brown-gray. Lacustrine

Like above but less silty and clayey, and better sorted

Sand, fine, and silty fine, dark-gray. La-

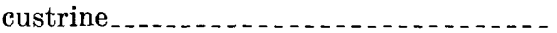

Clay and silty clay, dark-gray to nearly black. Lacustrine.

1. $5 \quad 4.5 \pm$

1. $5 \quad 6.0 \pm$

$.5 \quad 6.5 \pm$

1. $0 \quad 7.5 \pm$

Sand, medium, some coarse, very clayey (clay decreases downward, sand becomes cleaner) ; very dark gray. Lacustrine..

Base not reached.

\section{TABLE 10.-Stratigraphic sections-Continued Section 4}

NEY/4 sec. 33, T. 21 N., R. 30 E. Stratigraphic section exposed on south side of large deflation basin about 2144 miles east of Timber Lake. Top of section, altitude 3,885 \pm 5 feet.

Fallon formation and(or) Turupah formation:

1. Sand, fine to medium, dark-gray, much coarse sand and granules, browngray and black limestone fragments. Eolian

$\begin{array}{cc}\text { Thickness } & \text { Depth } \\ (\text { feet }) & \text { (feet) }\end{array}$

conformity.

Sehoo formation:

Lower member:

2. Clay, medium- to dark-olive-gray; blocky; ostracodes; some lenticular partings of ostracoderich fine sand as much as $1 / 8 \mathrm{in}$. thick. Lacustrine..........

3. Sand, fine, $\tan$; lacustrine

4. Clay, same as 2...............

5. Sand, laminated yellowish-brown, gray, and black, poorly sorted, well-indurated, laminae $1 / 8$ in., probably basaltic. Lacustrine.

6. Clay, same as 2, blocky to laminated; some brown and black staining on fractures. Lacustrine

7. Ash, volcanic, silt-sized, white to pale-gray. Lacustrine........

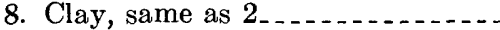

9. Sand, fine, tan, brown and orangebrown, laminated; ostracodes abundant. Lacustrine.........

10. Clay, same as 2.............

11. Ash, volcanic, white .........

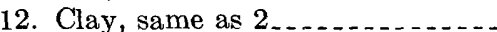

13. Ash, volcanic, white ..........

14. Clay, same as 2

2. $3 \quad 5.1 \pm$

$6 \quad 5.7 \pm$

Ash, volcanic, silt-sized, white. Lacustrine . . . . . . . . . . . . . . .

Clay, olive-green-gray; ostracodes. Lacustrine ....................

Sand, medium, brown; ostracodes. Lacustrine . . . . . . . . . . . . . . .

Clay, olive-green-gray, somewhat laminated, slightly mottled, brown along fractures; a few lenticular ostracode coquina partings, two white volcanic-ash partings 7 and 17 in. from top. Lacustrine....

Sharp, nearly level, regular contact.

Wyemaha formation:

Sand, medium, well-sorted, light- to medium-gray, mottled rusty yellow; upper 4 in. has several dark-brown ostracode-rich partings. Below, largely quartz grains; wide variety of rocktypes in nonquartz fraction, similar to those in present bed of Carson River. Lacustrine.

Base not exposed.

2. 0

2

5. $0 \quad 7$

$.05 \quad 7.05$

.1 7. 15

.25

7. 4

1. $9 \quad 9.3$

$.25 \quad 9.55$

1. $0 \quad 10.55$

$\begin{array}{ll}.15 & 10.7\end{array}$

$.7 \quad 11.4$

Line

1. $4 \quad 12.8$

Line

4. $0 \quad 16.8$

Wyemaha formation:

15. Sand, fine, rust-brown (base not exposed). Lacustrine.

Section 5

1. $0 \quad 17.8$

1. $0 \quad 6.7 \pm$

$16 \quad 6.9 \pm$

6. 3 13. $2 \pm$

Turupah formation, bearing Toyeh soil (eroded):

Sand, very fine, fine, and medium and coarse pebbly sand, interbedded; slightly micaceous; pebbles rarely to $1 / 2$ in. diameter; iron and manganese stains in coarse beds; strongly crossbedded. Eolian. Top several inches poorly sorted, with moderate soil calcium carbonate concentration (eroded $\mathrm{C}_{\mathrm{ca}}$ horizon of Toyeh soil);

$2+15.2 \pm \quad$ remainder is moderately well sorted and free of calcium carbonate
$2.3 \pm \quad 2.4 \pm$ 
TABLE 10.-Stratigraphic sections-Continued

Section 5-Continued

Unconformity representing subaerial erosion. Sehoo formation:

Upper member:

Sand, very fine, tan; some iron oxide nodules. Lacustrine..........

Clay, brown; gradational lower boundary. Lacustrine .........

Indian Lakes formation:

Upper tongue:

Clay, silty, very black, highly carbonaceous; marsh or swamp fluviolacustrine or lacustrine deposit ...........................

Disconformity.

Sehoo formation:

Dendritic member:

Clay, sandy, about 5 percent sand in top $1 / 2 \mathrm{ft}$, grades less sandy downward; olive green, has turquo ise blotches. Lacustrine....

Clay, bluish-green having rusty blotches; ostracodes. Lacustrine.

Clay, sandy, olive-green having teal-blue blotches; 15 to 20 percent sand; lacustrine...........

Base not exposed.
TABLE 10.-Stratigraphic sections-Continued Section 7

SW14SE1/4 sec. 21, T. 20 N., R. 28 E. Stratigraphic section exposed in scarp of deep deflation basin, and 5-foot auger hole at base of scarp. Top of section, altitude about 3,990 feet.

$\begin{array}{rr}0-1 \pm & 3.4 \pm \\ 3 \pm & 6.4 \pm\end{array}$

Fallon formation:

Sand, fine, coarse sand, and granule sand, a few pebbles to $1 / 4$ in. in diameter, rarely $1 / 2$ in., even at crest of dune; crossbedded. Eolian.....

Disconformity.

Turupah formation, bearing Toyeh soil $.5 \pm \quad 6.9 \pm \quad$ (eroded):

Sand, like above, eolian, bearing $\mathrm{C}_{\mathrm{oa}}$ horizon (eroded) of Toyeh soil; 0-2 in. (locally eroded) white layer at top that may be partly volcanic ash but has much soil calcium carbonate. Basal 1 in. of unit locally rust

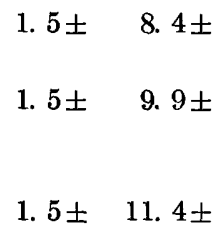
stained

Disconformity.

Sehoo formation:

Upper member:

Clay, silty, and sand, very fine, clean, pale-tan-gray to nearly white; mottled with white soil calcium carbonate (lower part of $\mathrm{C}_{\mathrm{oa}}$ horizon of Toyeh soil). Lacustrine.

0. 05-0. $2 \quad 9 \pm$

Sand, mostly fine; $1-3$ in. poorly sorted, coarse, medium, and fine sand locally at top and base. Parallel bedded. Probably lacustrine. . . . . . . . . . . . . . . .

Disconformity : undulating erosion surface.

Sand, medium, yellow-brown, slightly cemented; seems to bear incipient soil (top is noncalcareous, lower part seems to have some soil calcium carbonate concentration). Parallel bedded. Lacustrine.........

Silt, sandy, and sand, silty, dark-

$\begin{array}{cc}\text { Thickness } & \text { Depth } \\ \text { (feet) } & \text { (feet) }\end{array}$

$8 \pm \quad 8 \pm$

0. 8-1. $0 \quad 9 \pm$

$.7 \pm \quad 9.7 \pm$

$0-0.5 \quad 10 \pm$

$0.4 \pm \quad 10.4 \pm$

Sand, medium and fine, yellow to medium-gray, well-sorted, well-bedded, poorly consolidated. Lacustrine

Sand, fine, silt, some clay, thinly interbedded. Lacustrine...........

Sand, coarse, medium, and fine, interbedded; dark-gray, highly andesitic or basaltic; generally well indurated, well-bedded. Lacustrine. Probably correlative with late eruptions at Upsal Hogback .................

Base not exposed. chocolate-brown, much soil calcium carbonate; parallel bedded. Lacustrine

$7 \pm$

$17 \pm$

$$
7 \pm
$$$$
5 \pm
$$

$24 \pm$

$5 \pm$

$29 \pm$

Disconformity.

Indian Lakes formation (of late Sehoo and Indian Lakes age) :

Sand, fine-medium, light-gray; eolian. Top $1 \mathrm{ft}$ has some coarse sand; middle 0.5 to $1 \mathrm{ft}$ is slightly cemented with calcium carbonate, overlies very irregulau erosion surface; lower 0.5 to $1.2 \mathrm{ft}$ is uncemented.......
$3 \pm \quad 13.4 \pm$ 
TABLE 10.-Stratigraphic sections-Continued

Section 7-Continued

Sehoo formation:

Upper member:

Sand, fine, well-sorted, parallelbedded. Lacustrine........-

Silt, and sand, very fine; top 5 in. brown-gray to medium-gray silt having very fine sand partings; middle $7 \mathrm{in}$. is light-gray very fine sand; bottom 6 in. is silt and a little very fine sand, laminated dark brown gray, dark gray, some medium gray and light gray. Lacustrine..-

Disconformity, undulating erosion surface.

Sand, fine, and fine-medium, wellsorted, some partings of basaltic(?) sand, possibly from Soda Lake eruptions; lowest $1 \mathrm{ft}$ has some coarse sand; local 1/4-in. somewhat cemented light-gray very fine sand (ash?) parting at base.....................

Disconformity.

Dendritic member(?), possibly bearing

Harmon School soil (eroded):

Sand, coarse and medium, fragments of pale-gray platy lithoid tufa $0.1 \mathrm{in.} \mathrm{thick;} \mathrm{medium-}$ brown, slightly indurated and cemented with calcium carbonate; possibly bears eroded weak soil. Lacustrine...............

Dendritic member:

Sand, very fine, and fine, wellsorted, unindurated, micaceous, pale-gray; loose and flourlike. Lacustrine.

Silt, light-tan-gray, well-sorted. Lacustrine

Silt, clayey, and clay, silty, interbedded, light to medium-gray. Lacustrine. ................

Silt, pale-gray, and interbedded very fine sandy silt to clayey silt_........................

Sand, very fine, well-sorted, palegray . . . . . . . . . . . . . . . . . .

Dendritic member(?):

Silt and very fine sandy silt, slightly coherent, light-gray. Lacustrine.................

Lower member:

Silt, clayey, somewhat micaceous; ostracodes; some selenite; medium-gray; thinly laminated, semicoherent, fissile. Lacustrine . . . . . . . . . . . . . . . . .
TABLE 10.-Stratigraphic sections-Continued

Section 7-Continued

Sehoo formation-Continued

Lower member-Continued

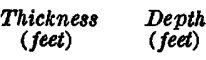

Clay, silty, semi-indurated, medium-gray; well-bedded; ostracodes. Lacustrine; grades to clayey silt and silty clay near base

$7.5 \pm \quad 35.0 \pm$

Sharp, even, conformable contact.

Wyemaha formation:

Sand, medium and fine-medium, some interbedded fine sand; moderate yellowish brown (10YR 6/4) to palegray (particularly yellowish in upper part). Probably all lacustrine. Base not reached.............. $72 \pm$

Section 8

Type locality for upper member of Sehoo formation. Exposure in borrow pit at north scarp of deflation basin, about 100 feet west of Fallon-Lovelock cutoff road, in $S E 1 / 4 N W_{1 / 4} \mathrm{sec}$. 32, T. $20 \mathrm{~N}$., $R$. 29 E.; top of section, altitude about $9,995 \pm 5$ feet.

Fallon formation:

Sand, fine, medium, and coarse, paleyellow-gray, poorly sorted, locally crossbedded. Eolian. (Northward thickens to more than $10 \mathrm{ft}$ and is underlain by several feet of eolian sand of the Turupah formation, which bears the Toyeh soil) .......

$\underset{(\text { feet })}{\text { Thickess }} \begin{gathered}\text { Depth } \\ (\text { feet })\end{gathered}$

$.3 \pm \quad 19.6 \pm$

Disconformity.

Sehoo formation:

Upper member (bearing Toyeh soil, slightly eroded) :

$.5 \pm 20.1 \pm \quad$ Sand, coarse and medium, containing much granule sand and some pebbles (mostly less than $1 / 4$ in., some to $1 / 2$ in., and rarely about 1 in. diameter); rather poorly sorted, indistinctly bedded. Lacustrine. Granules and pebbles mostly late lithoid tufa of upper member of Sehoo, medium to dark gray or dark brown gray; rare fragments of white early lithoid tufa of this member and of voleanic and granitic rocks. Top 2-4 in. is oxide (B) horizon of Toyeh soil (pH 6.8 by colorimetric field test); next 9-10 in. is $\mathrm{C}_{\mathrm{oa}}$ horizon of this soil (partly cements the sand; pH 8.0-8.5) ........

Contact gradational to sharp, some1. $0 \pm 27.5 \pm$ ity. what undulating; local disconform-
$2 \pm \quad 2 \pm$
$2 \pm \quad 4 \pm$ 
TABLE 10-Stratigraphic sections-Continued

Section 8-Continued

Sehoo formation-Continued

Upper member:

Sand, medium, some fine-medium, and coarse, granule-bearing coarse; rare fragments of early lithoid tufa of upper member of Sehoo. Lacustrine. Mostly poorly consolidated; bedding lenticular, locally crossbedded.-

Fairly sharp, nearly level contact.

Sand, fine-medium and fine, thinly bedded; upper half ripple-crosslaminated, strongly so in top 2 in.; lower half almost parallel bedded; ripple marks approximately symmetrical. A few small nodules of medium-brown lithoid tufa in top half; some fragments of white early lithoid tufa of this member in lower half, especially at base. Lacustrine .........

Sharp, somewhat undulating contact; disconformity; in places cuts bedding in underlying lake clay.

Lower member:

Clay, mostly silty, very light olive gray; lower $2 \mathrm{ft}$ is pale-gray silt. Well parallel bedded. Lacustrine. Prismatic jointing, which becomes closer in top few incbes; sand dikelets in some joints. Top several inches appear slightly weathered (clay is discolored and fragmented); possibly lower part of Harmon School soil...

Sharp, level, conformable contact.

Wyemaha formation:

Sand, medium, light-brownish-yellow, well-sorted, incoherent. Well parallel bedded. Lacustrine.............

Base not exposed.

Section 10
TABLE 10.-Stratigraphic sections-Continued Section 10-Continued

\begin{tabular}{|c|c|c|}
\hline $\begin{array}{c}\text { Thickness } \\
(\text { feet })\end{array}$ & $\begin{array}{l}\text { Depth } \\
\text { (feet) }\end{array}$ & $\begin{array}{l}\text { Volcanic sand complex of Soda Lake-Con. } \\
\text { Contact poorly exposed. }\end{array}$ \\
\hline $2 \pm$ & $6 \pm$ & $\begin{array}{l}\text { Part of middle Sehoo and Indian Lakes age: } \\
\text { 2. Sand, coarse, and granule sand, } \\
\text { with several percent of basaltic } \\
\text { lapilli; some very small basalt } \\
\text { pebbles; well-sorted, nearly un- } \\
\text { indurated, moderately to well } \\
\text { bedded; probably lacustrine... }\end{array}$ \\
\hline
\end{tabular}
Thickness
(feet) $\quad \begin{gathered}\text { Depth } \\ \text { (feet) }\end{gathered}$ Contact poorly exposed.

of middle Sehoo and Indian Lakes age: with several percent of basaltic lapilli; some very small basalt ndurated, moderately to well

3. Lapilli sand and granule sand; commonly more than 20 percent basaltic lapilli and with some basaltic pebbles, mostly less than $1 / 2$ in. diameter, but rarely to several inches diameter (bombs) in some beds; lower part mostly well-sorted, low in silt and relatively unindurated; upper part is moderately sorted, somewhat to very silty, somewhat indurated, forms small cliffs locally. Contains rare waterworn fragments of dendritic and lithoid tufa. Lacustrine.....................

Sharp conformable contact.

4. Silt and sandy silt, light-gray, very poorly sorted; many beds contain several percent of basaltic lapilli (sand-, granule-, and smallpebble-sized); somewhat indurated; lacustrine. . . . . . . ........

$\begin{array}{ll}2.2 & 85.7\end{array}$

Sharp contact, possible minor disconformity.

5. Sand, lapilli; very fine pebbly medium sand, very poorly sorted, grayish-yellow-brown, slightly indurated, indistinctly bedded; probably colluvium (slope wash or talus). (At next embayment of bluff to the east, this unit is somewhat more indurated, yellower and locally shows slight calcium carbonate concentration at top.) . . . .

Gradational contact.

6. Sand, lapilli; mostly coarse, finepebbly, and granule sand, some medium sand, especially in upper $2 \mathrm{ft}$; generally well sorted; practically all basaltic lapilli; pebbles mostly less than $1 / 2$ in., rarely to 1 in.; slightly indurated; contains occasional waterworn fragments of dendritic and lithoid tufa. Lacustrine............ horizon (eroded) of the Toyeh soil

Sharp conformable contact. 
TABLE 10.-Stratigraphic sections-Continued

\section{Section 10-Continued}

Volcanic sand complex of Soda Lake-Con.

Part of middle Sehoo and Indian Lakes age-Continued

7. Silt, medium-grayish-brown, wellsorted, unindurated; thins rapidly westward and is only $1 / 2 \mathrm{ft}$ thick $10 \mathrm{ft}$ to west. Lacustrine......

Angular disconformity.

Part of early Sehoo(?) and Indian Lakes age:

8. Sand, lapilli; moderately indurated, moderately well bedded, parallel bedded; dips $20^{\circ}-30^{\circ}$ northwestward; strongly jointed. Contains several percent of basaltic lapilli in poorly sorted silty medium to coarse sand, and commonly some grit, small-pebble-sized lapilli, and rare cobble-sized basalt bombs. Lacustrine. Base not exposed; thickens to several feet, locally as much as $15 \mathrm{ft}$; exposed above water within $400 \mathrm{ft}$ to west

\section{Section 13}

$N E_{74}^{1 / 4} N E_{1 / 4}^{1}$ sec. 17, T. 19 N., R. 29 E. Stratigraphic section exposed in riverbank at west edge of Carson River flood plain, altitude $3,945 \pm 5$ feet.

Turupah formation, bearing Toyeh soil:

1. Sand, medium light-gray. Two parts, undulating disconformity between: upper part, $0.5-3 \mathrm{ft}$ thick, is indistinctly bedded; lower part, $0.5-3 \mathrm{ft}$ thick, is crossbedded, contains some coarse sand and grit, and many tufa fragments. Eolian. Bears Toyeh soil; top several inches (oxide horizon) are almost unindurated; underlying material has moderate to weak calcium carbonate concentration (calcareous horizon) to 14-16 in. depth.................

Pronounced disconformity, slightly undulating, crosscuts bedding in underlying unit. Sehoo formation:

Lower member:

2. Silt, clayey, pale-gray. Several ostracode-rich sand partings in upper part; 3 in. above base is persistent $1 / 4$-in. parting of silty lacustrine limestone; abundant worm-boring tubules below the limestone parting. Lacustrine.

Flat, conformable contact.

Wyemaha formation:

3. Sand, fine, silty, mostly; some silt partings and thin beds of coarsemedium sand. Strongly ripplemarked and layers locally broken as if by wave action in shallow water. Abundant worm tubules. Lacustrine.

\section{$\begin{array}{cc}\text { Thickness } & \text { Depth } \\ \text { (feet) }\end{array}$}

1. $3 \quad 95.5$

96. 5
1. $4 \pm \quad 4.4 \pm$

Thickness Depth

2. $2 \pm \quad 6.6 \pm$
$3 \pm \quad 3 \pm$
TABLE 10.-Stratigraphic sections-Continued

Section 13-Continued

Wyemaha formation-Continued

Disconformity.

4. Sand, medium, well-sorted, lightgray; horizontally parallel bedded; 2- to 3-in. silt layer at base. Lenticular and locally absent. Lacustrine.

$0-1 \quad 7.6 \pm$

Disconformity.

5. Sand, medium, some fine and coarse, well-sorted, light-gray, strongly crossbedded (beds dip northward). Probably eolian ...................

6. Sand, medium, light-gray, well-sorted; flat parallel bedded. Probably eolian.............................

7. Sand, medium, well-sorted, strongly crossbedded (beds dip northward). Eolian.

Thickness
(feet) (feet) feet)

Sand, medium, well-sorted; flat parallel bedded. Eolian or lacustrine. (Base not exposed)

NE $1 / 4 S E 1 / 4$, sec. 22, T. 19 N., R. 29 E. Stratigraphic section exposed by trench and pits into wash-bank scarp on east side of small valley, half a mile east of S-Line Reservoir; top of section, altitude 3,955 feet.

Fallon formation:

1. Sand, medium and coarse, pale-tan-

Thickness Depth gray, loose and uncemented; 15 percent dark-gray fragments of late lithoid tufa of upper member of Sehoo, including thin tabular ones $1 / 2$ to $3 / 4$ in. wide; indistinctly stratified. Eolian.

1. $5 \pm \quad 10.1 \pm$

1. $5 \pm \quad 11.6 \pm$

$3+\quad 14.6 \pm$ (feet) (feet)

Sharp contact; disconformity.

Turupah formation (bearing Toyeh soil):

2. Sand, medium and coarse, somewhat silty, poorly sorted, indistinctly bedded; some tufa fragments. Eolian. Top $1.3 \mathrm{ft}$ bears Toyeh soil, which locally is somewhat eroded; vesicular horizon is locally absent; oxide horizon is 2-5 in. thick, grayish-brown, containing a little semiflocculated clayey silt, little or no calcium carbonate; moderate coarse columnar structure, hard consistence; gradual boundary; remaining. 8-11 in. are calcareous horizon; pinkish-gray, moderately calcareous, moderately cemented, hard consistence, containing many white powdery calcium carbonate concentrations; slightly columnar to granular structure; gradual lower boundary. Material below soil is light brownish gray, very weakly indurated...
1. 5-2. 2

5. $0 \pm$ 
TABLE 10.-Stratigraphic sections-Continued

Section 16-Continued

Disconformity.

Sehoo formation:

Upper mer_ber:

3. Granule-sand and coarse sand, pinkish-gray, very well sorted arkosic; some small pebbles to rarely $1 / 2$ in. diameter, typical Carson River assemblage; also many thin platy fragments of dark-purplishred tufa. Top 3-4 in. somewhat cemented by calcium carbonate and slightly darker; lower part is uncemented. Lacustrine (deltaic)

7. $2 \pm$

4. Sand, fine, and silty, light brownish-yellow. Lacustrine

0-0.3

Disconformity representing upper tongue of Indian Lakes formation. Sharp undulating contact; records subaerial erosion.

Lower member :

5. Clay, silty, and nonsilty, medium-gray, faint greenish cast; tough, moderately indurated, faintly laminated; prismatic jointing; some ostracods. Lacustrine _...

Sharp even contact.

Wyemaha formation:

6. Sand, medium, well-sorted, uncemented, bright-orange-yellow; ripple-bedded. Lacustrine....

7. Sand, very coarse, clean, pale-gray. Lacustrine....................

8. Sand, fine medium, clean, paleyellow-brown-gray. Lacustrine

9. Silt or silty clay, medium-browngray. Lacustrine

10. Sand, fine-medium, clean, palebrown-gray; irregular parting of silt at base. Lacustrine....

11. Sand, fine-medium, clean, palebrown-gray. Lacustrine .....

12. Silt and clayey silt, medium-yellow-brown-gray. Lacustrine - -

13. Sand, medium and fine-medium, clean, pale-brown-gray. Lacustrine

14. Silt, clayey silt, silty clay and fine sand in alternate layers; 1 in. clay at base; medium-yellowbrown-gray. Lacustrine......-

TABLE 10.-Stratigraphic sections-Continued

Section 16-Continued

Wyemaha formation-Continued

Thickness Depth

15. Sand, medium, clean, medium-yellow-brown; $1 / 2$ in. fine sand, light-gray, at base. Lacustrine

16. Sand, coarse-medium, very well sorted, pale-gray, Lacustrine.

0.8

1. $3 \quad 16.2 \pm$

17. Sand, fine, $1 / 2$ to 1 in. at top; remainder coarse medium sand and medium sand; light yellowbrown. Lacustrine. Base not exposed......................

1. $5+\quad 17.7 \pm$

7. $4 \pm$

2-2. $5 \quad 9.6 \pm$

10. $9 \pm$

$.1-.3 \quad 11.1 \pm$

.3

11. $4 \pm$

$.05 \quad 11.4+$

Type locality of upper tongue of Indian Lakes formation and Harmon School soil: $2 / 3$ mile north of old Harmon School, SW1/4 NW1/4 sec. $24, T .19$ N., R. $29 \mathrm{E}$. Exposed in banks of a branch irrigation canal about 150 feet east of county road bridge across main irrigation canal. Top of section at altitude of about 3,932 4 feet. See also soil profile $17 \mathrm{~S}$ (table 12) at this locality.

Sehoo formation:

Upper member (bearing toyeh soil):

Silt and fine sand, thinly interbedded. Lacustrine. Upper 3.5 in. light gray, having vesicular structure (vesicular horizon of Toyeh soil); remainder is light brown, having weakly columnar to granular structure; slightly to moderately calcareous ( $B$ and upper part of $\mathrm{C}_{\mathrm{ca}}$ horizons of Toyeh soil) . . . .

Irregular contact.

Lithoid tufa, white to pale gray (early lithoid tufa of this member), nearly continuous layer of irregular to mammilary masses, commonly 1 to $2 \mathrm{ft}$ in diameter and 0.2 to $0.8 \mathrm{ft}$ thick

$\begin{array}{cc}\text { Thickness } & \text { Depth } \\ \text { (feet) }\end{array}$

$1 \pm \quad 1 \pm$ mity; fairly sharp contact.

Disconformity; fairly sha

Upper member (bearing Harmon School soil):

Colluvium, composed of fragments of underlying clay. Top 0-2 in. light brown (oxide horizon of Harmon School soil); remainder is light olive gray; has very weak calcium carbonate concentration in upper $0.7 \mathrm{ft}\left(\mathrm{C}_{\mathrm{ca}}\right.$ horizon of same soil)

$3 \pm \quad 4.5 \pm$

Disconformity.

Sehoo formation:

Dendritic member:

Clay, silty, and clayey silt, light-olivegray; strong columnar jointing; joints closer spaced in top $1 \pm \mathrm{ft}$. Lacustrine. Base not exposed...

$.5 \pm \quad 1.5 \pm$

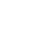

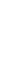

$\begin{array}{lr}.15 & 11.6 \pm \\ .3 & 11.9 \pm \\ .3 & 12.2 \pm \\ 1.2 & 13.4 \pm\end{array}$

$.7 \quad 14.1 \pm$ 
TABLE 10.-Stratigraphic sections-Continued

Section 18

NE1/4SE1/4 sec. 25, T. 19 N., R. 29 E. Stratigraphic section exposed in bank of drainage canal, and in 6-foot auger hole, in delta of second Fallon lake. Top of section, altitude 3,991 feet. Fallon formation:

Second lake unit (bearing "L" Drain Thickness Depth soil):

1. Sand, coarse and medium, somewhat pebbly, especially in basal one-half foot (pebbles to $1 / 3$ in. diameter); well-sorted, except top $0.5 \mathrm{ft}$, which is silty; about top $1.2 \mathrm{ft}$ slightly indurated by L-Drain soil. Upper part lacustrine, lower part distributary (deltaic) alluvium

Sharp contact, disconformity.

First lake unit:

2. Silt, well-sorted, light-brownishgray; some sand-filled desicca-. tion cracks, rusty spots, and spots of weak calcium carbonate concentration. Lacustrine

3. Sand, medium, grading to finemedium in lower part, wellsorted, light-yellow-browngray. Lacustrine

Turupah formation:

4. Sand, coarse and medium, with granules and very small pebbles (typical Carson River assemblage); indistinctly bedded. Alluvium Carson River channel sand) ...... Base not reached.

Section 22a

NW1/4NW1/4 sec. 35, T. 19 N., R. 30 E. Auger hole in Stillwater Slough flood plain, beside Stillwater Reservoir diversion canal. Top of section, altitude $8,915 \pm 3$ feet.

Fallon formation:

Upper member:

1. Silt, sandy, dark-gray; alluvium _- $\quad 1 \pm \quad 1 \pm$

Disconformity.

Lower member (probably second lake unit):

2. Clay, silty, dark-gray mottled with tan; highly saline, gypsiferous. White pumiceous $1 / 2$ - to 1 -in. ash parting about 4 in. above base. Lacustrine

Possibly first interlake unit:

3. Silt, clayey, sandy, poorly sorted, probably alluvium...........

Disconformity?
TABLE 10.-Stratigraphic sections-Continued

Section 22a-Continued

Fallon formation-Continued

Probably first lake unit:

4. Silt, clayey, olive-drab. Lacustrine ..........................

5. Sand, fine, silty in top $0.1 \mathrm{ft}$, clean below; tan and tan-gray. Lacustrine.............................

6. Sand, fine, clean, interbedded with silt and silty fine sand. Lacustrine

7. Silty clay and clayey silt, darkbrown. Lacustrine............

8. Sand, silty, fine, dark-tan-gray. Lacustrine.-...............

9. Clay, silty, dark-tan-gray, some silty-sandy clay. Lacustrine ...

Disconformity.

Sehoo formation:

Upper or dendritic member:

10. Clay, dark-olive-tan mottled with black. Lacustrine . . . .......

11. Clay, silty, olive mottled with dark gray. Lacustrine......-
1. $5 \quad 5.6 \pm$

1. $9 \quad 7.5 \pm$

$7 \quad 14.5 \pm$

$\begin{array}{cc}\text { Thickness } & \text { Depth } \\ \text { (feet) } & \text { (feet) }\end{array}$

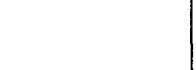
$.7 \quad 3.9$
Dendritic (?) member:

12. Clay, olive. Lacustrine.......

Dendritic member and possibly lower member:

13. Clay, like 12, but with tufa nodules, oolites, and especially abundant ostracodes, in top 2 ft. Lacustrine

Probably lower member:

14. Clay, silty, olive to olive-tan, tan, and olive-tan-gray; mottled with rust-brown spots. Lacustrine

1. $0 \quad 5.1$

1. 26.3

$\begin{array}{ll}.5 & 6.8\end{array}$

$.6 \quad 7.5$

1. $3 \quad 8.8$

.8

$.9 \quad 10.5$

2. $6 \quad 13.1$

Base not reached.

\section{Section 22b}

NW1/4SW1/4 sec. 35, T. 19 N., R. 30 E. Auger hole in flat between Sehoo Mountain and Stillwater Slough. Top of section, altitude $3,919 \pm 3$ feet.

Fallon formation:

Lower member:

1. Sand, clayey, fine, hard-cemented, dark-gray to nearly black, saline. Grades to fine-sandy clay at base. Mainly lacustrine ...........

2. Clay, locally with silt and a little very fine sand; dark-brown-gray to nearly black; saline segregations, especially in lower part. Lacustrine ..................

3. Clay, same as 2 , with abundant calcium carbonate nodules and salt segregations. Nodules are mostly $1 / 8$ to $1 / 4$ in., rarely $1 / 2$ in. diameter, irregular forms ........ $\begin{array}{cc}\text { Thickness } & \text { Depth } \\ \text { (feet) }\end{array}$

1. $5 \quad 1.5$

2. $5 \quad 4.0$

1. $0 \quad$ 5. 0 
TABLE 10.-Stratigraphic sections-Continued

Section 22b-Continued

Fallon formation-Continued

Lower member-Continued

4. Clay, tan-gray, without calcium carbonate nodules. Lacustrine.

5. Clay, silty, black mottled with tan. Lacustrine.

Disconformity representing subaerial exposure. Sehoo formation:

Upper member:

6. Clay, grayish-olive-green mottled with black (carbonaceous matter-probably from vegetation during lake desiccation). Lacustrine...............................

7. Clay, silty, dark-yellow-brown, saline. Lacustrine.............

8. Clay, silty, dark-yellow-brown to dark olive-tan, mottled with rusty-brown spots; selenite crystals and white saline segregations (probably mostly gypsum). Lacustrine

Dendritic member:

9. Clay, silty, grading downward to clay; olive; 1.3 to $1.8 \mathrm{ft}$ below top, unit contains whitish partings or segregations, some with abundant ostracodes. Lacustrine...........................

10. Clay, silty, mostly olive, some brown spots. Lacustrine ......

11. Clay, limy (effervesces strongly with $\mathrm{HCl}$ ) ; tufa nodules. Lacustrine

12. Clay, olive. Lacustrine ....... Thinolite member:

13. Clay, olive; contains minute thinolite erystals. Lacustrine....... Lower member:

14. Clay, olive. Lacustrine....... . . $6+17.0$

Base not reached.

Section 23:

$S E 1 / 4 N W 1 / 4$ sec. 2, T. 18 N., R. 30 E. Auger hole in flat north of Sehoo Mountain; top of section, altitude 3,922 \pm 3 feet.

Fallon formation:

Second lake unit:

$\begin{array}{cc}\text { Thickness } & \text { Depth } \\ \text { (feet }) & (\text { feet })\end{array}$

1. Sand, fine-medium, tan, clean. Lacustrine..................

2. Sand, fine-medium, silty to clayey, dark-brown-gray. Lacustrine.

First lake unit:

3. Clay, silty, dark-brown to black. Lacustrine .................

4. Clay, silty, tan, with black streaks, and some sandy clay. Lacustrine

5. Clay, silty, dark-brownish-gray. Lacustrine.....................

Disconformity.
TABLE 10.-Stratigraphic sections-Continued Section 23-Continued

Sehoo formation:

Upper member:

6. Clay, mottled-black to olive-tan. Lacustrine .....................

Dendritic member:

7. Clay, olive, with rusty spots. Lacustrine .....................

8. Clay, slightly silty, olive-gray; very limy, with ostracodes, oolites, and small white calcium carbonate (tufa) nodules (small irregular rounded forms resembling clusters of oolites), with thin laminae of limy sand (rich in oolites and ostracodes); in lower $2 \frac{1}{2} \mathrm{ft}$ some small selenite segregations. Lacustrine...............

$\begin{array}{cc}\text { Thickness } & \text { Depth } \\ \text { (feet) }\end{array}$

1. 2 4. 2

$.8 \quad 5.0$

5. $0 \quad 10.0$

Thinolite unit:

9. Clay, as in 8 , but with minute crystals of thinolite

2. $0 \quad 12.0$

Lower member:

2. 3 8. 7 10. Clay, somewhat silty, drab olivebrown-gray (more silty and brown, less green than unit 8); minute mica flakes. Oolites and small tufa nodules common in top $1 \mathrm{ft}$, none below. Below top $2 \mathrm{ft}$ the clay commonly contains some very fine sand and is very constant in lithology. Lacustrine .................

11. $4 \quad 23.4$

11. Ash, white, volcanic (pumiceous), cemented, very hard. Lacustrine.......................

Section 24

$.6 \pm 24 \pm$

SE1/4SW1/4 sec. 2, T. 18 N., R. 30 E. Auger hole in flat north of Sehoo Mountain. Top of section, altitude 3,926 13 feet.

Fallon formation:

First lake unit:

1. Sand, fine-medium, more or less silty and clayey (especially near bottom); somewhat cemented with calcium carbonate. Lacustrine .......... $\begin{array}{cc}\text { Thickness } & \text { Depth } \\ \text { (feet) } & \text { (feet) }\end{array}$

Disconformity.

2. $0 \quad 2.0$

Sehoo formation:

Dendritic member:

0.6 6.6 2. Clay, somewhat silty, with tufa nodules, oolites, and ostracodes; olive-gray. Lacustrine . . . . . . . .

3. $0 \pm \quad$ 5. $0 \pm$

Thinolite unit:

\begin{tabular}{ll|l}
.5 & 1.7 & 3 . Clay, as in 2 , with thinolite tufa
\end{tabular} crystals, generally $<1 / 32$ in. thick and $1 / 32$ to $1 / 8$ in. long, most abundant $2 \mathrm{ft}$ below top of unit, decreasing upward and downward from this level. Lacustrine

3. $5 \quad 8.5 \pm$ 
TABLE 10.-Stratigraphic sections-Continued

Section 24-Continued

Sehoo formation-Continued

Lower member:

4. Clay, silty, becoming more silty downward, olive-gray. $21 / 4 \mathrm{ft}$ below top of unit is about 1-in. layer of grit and small pebbles to $3 / 4$ in. diameter. Starting at $4 \mathrm{ft}$ below top of unit are a few partings of fine sandy silty clay, and in lower $13_{2} \mathrm{ft}$ these are common. Lacustrine.....

5. Ash, white, pumiceous, hard-

Section 25

$1 / 4$ mile east of $S W$ cor. sec. 4, T. 18 N., R. 29 E. Bank of drainage canal and 2-foot auger hole at bottom of canal. Top of section, altitude 3,947 feet.

Fallon formation:

First interlake unit (bearing L-Drain Soil):

Sand, fine and very fine, clean, light-brown-tan. Eolian. Top $1 \mathrm{ft}$ is weakly indurated by very weak soil profile (L-Drain soil)

First lake unit:

Sand, fine, dark-tan, clean. Lacustrine .......... . . . . . . .

Silt, sandy, dark-olive-gray. Lacustrine

Disconformity.

Sehoo formation:

Upper member(?):

Clay, fine-sandy, gray-brown.

Lacustrine

Base not reached.
Thickness

(feet)

Depth

13

21. $5 \pm$

$.3 \quad 21.8 \pm$

1. $5 \pm \quad 3 \pm$

$0.3-0.5 \pm \quad 3.5 \pm$ (feet)

\section{1. $5 \pm \quad 1.5 \pm$}

\section{Section 28}

$1 / 4$ mile west of SE cor. sec. 11, T. 18 N., R. 29 E. Stratigraphic section exposed in bank of drainage canal, and 3 -foot auger hole in canal bed, in delta of first and second Fallon lakes. Top of section, altitude about 3,930 feet.

Fallon formation:

Second lake unit:

Sand, fine and medium, poorly to moderately sorted, light-tan-gray. Lacustrine

First lake unit:

Sand, silty. Lacustrine ........... 205

Clay, brown-gray. Lacustrine ..... 49

Disconformity.

Sehoo formation:

Upper member:

Clay, sandy and silty. Lacustrine...

Dendritic and (or) lower members:

Clay, greenish-gray, tough. Lacustrine -

Base not reached.

TABLE 10.-Stratigraphic sections-Continued

Section 29

0.2 mile south of $1 / 4$ sec. cor. between secs. 9 and 10, T. 18 N., R. $30 \mathrm{E}$. Auger hole in flat north of Fish Cave at 3,927-foot shoreline of second Fallon lake. Top of section, altitude $3,927 \pm 3$ feet.

Fallon formation:

$\begin{array}{cc}\text { Thickness } & \text { Depth } \\ \text { (feet) } & \text { (feet) }\end{array}$

Second lake unit:

i. Sand, fine-medium, dark-gray to black, silty, carbonaceous; many clam and snail shells. Lacustrine................................

2. Sand, fine-medium, yellow-brown. Lacustrine

$0.2 \quad 0.2$

Disconformity.

First lake unit:

3. Silt and clay, dark-gray to black (with local rusty spots along former roots), carbonaceous. Lacustrine.

3. $6 \quad 4.3$

4. Sand, fine, clayey and silty, with some interbeds of fine sandy silt, medium-dark-tan-gray. Lacustrine

2. $1 \quad 6.4$

Disconformity.

Seboo formation:

Dendritic member:

5. Clay, somewhat silty, greenish-gray, Lacustrine ......................

Thinolite member:

6. Clay, as in 5, with abundant small thinolite crystals in upper 0.9 $f t$ and a few in lower part. Lacustrine

Lower member:

7. Clay, silty, green-gray (with rustbrown spots); upper part somewhat micaceous. Lacustrine..-

8. Sand, medium, clayey to clean, rust-brown. Lacustrine.......

9. Clay, silty and fine-sandy, greengray; lower half contains abundant calcium carbonate nodules and andesite-basalt pebbles to $1 / 8$ in. diameter. Lacustrine....

10. Clay, sandy, green-gray, with silty clay, viridian-green, at base. Lacustrine .................. . 5

$.2 \quad 19.2$

.3

19. 5

20. 0

Wyemaha formation:

11. Sand, fine, clean, grayish-olive-tan. Lacustrine .

12. Silt, green, with rusty spots. Lacustrine.................................

13. Silt, clayey silt and silty clay, darkgrayish-viridian-green; organic smell (similar to decaying vegetation). Lacustrine . . . . . . . . . . . . . . . . .

14. Clay, silty, dark-greenish-gray, darkgray, to nearly black; strong organic smell. Lacustrine
$.5 \quad 20.5$

$\begin{array}{ll}3 & 20.8\end{array}$

2.223 .0

1. $5+24.5$ 
TABLE 10.-Stratigraphic sections-Continued

Section 30

$S E 1 / 4 S_{1 / 4}^{1}$ sec. 12, T. 18 N., R. 30 E. Stratigraphic section exposed at head of miniature box canyon in gully at north edge (base) of pediment between Sehoo Mountain and Rainbow Mountain. Top of section, altitude $4,020 \pm 10$ feet.

Fallon formation and Lahontan Valley group, $\begin{gathered}\text { Thickness } \\ \text { (feet) }\end{gathered}$ (feet) undifferentiated:

1. Lake gravel and sand and eolian sand, undifferentiated...................

Pre-Lake Lahontan Quaternary lacustrine deposits (bearing Cocoon soil, much-eroded):

2. Sandstone, coarse, and gritstone, pebbly, well-cemented, hard, with thick parallel bedding. Fractures filled with calichelike calcium carbonate, resembling that in lower part of $\mathrm{C}_{\mathrm{ea}}$ horizon of Cocoon soil. Probably lacustrine.-

Pre-Lake Lahontan Quaternary lacustrine deposits:

3. Sand, pebbly sand, and gravel, mostly rather poorly sorted, partly consolidated, indistinct, parallel bedding. Probably lacustrine ...............

4. Sandstone, white, tuffaceous, hard....--

5. Sand, pebbly, and sand, clean, crossbedded, partly consolidated. Probably lacustrine.........

Base not exposed. $0-10 \quad 10 \pm$ Disconformity.

Dendritic member (bearing lower part of Toyeh soil, eroded):

4. Clay, silty, olive-green; some pale-greenish-gray interbeds of silt and silty clay, possibly altered volcanic ash; some lenticular limestone partings, generally less than $1 / 8$ in. thick and several inches across; very saline; some soil-lime concentration (eroded $\mathbf{C}_{\mathrm{o} a}$ horizon of Toyeh soil). Lacustrine....--

Nore.-Units 2 to 5 probably are shore sediments of a pre-Lake Lahontan Pleistocene lake. At the section locality they dip about $2^{\circ} \mathrm{N}$. and are displaced by three small faults, downthrown on the north side. Twenty feet north, unit 2 is eroded and the lower units grade rapidly to poorly sorted medium gravel dipping about $45^{\circ} \mathrm{SE}$., evidently part of a lacustrine bar or spit. This gravel contains pebbles of white tuff and diatomite similar to material in the upper part of the Truckee formation on the pediment to the south. This exposure appeas to be in $a$ fault sliver that is bounded by two inferred (concealed) east-west faults near its upper and lower ends (pl. 3).

Section 31

NW 144 NW1/4 sec. 7 (unsurveyed, T. 18 N., R. 81 E. Stratigraphic section, from several dug pits in high-shore sandbar of first Fallon lake and 2-foot auger hole, in flat northwest of Rainbow Mountain. Top of section, altitude $\$, 948 \pm \$$ feet.

Fallon formation:

First lake unit:

1. Sand, pebbly, mostly medium sand, fairly clean, some small pebbles; gray platy tufa like that of 3 and that of the local Tertiary volcanic rocks: mostly pumice, some Eagles House rhyolite and Bunejug formation. Lacustrine.

2. Sand, medium, with rare pebbles, tan, grading downward to finemedium sand, mostly clean, rusty to golden-brown, and then to clayey fine-medium sand, olive-tan, near base. Lower part contains some fragments of tufa, like that of 3 . Highly saline, much gypsum. Lacustrine

Disconformity.
$5 \pm 19 \pm$

$.119 \pm^{\circ}$

$5 \pm \quad 24 \pm$ Thickness Depth

$\begin{array}{cc}\begin{array}{c}\text { Thickness } \\ (\text { feet })\end{array} & \begin{array}{c}\text { Depth } \\ \text { (feet) }\end{array} \\ & \\ 2 \pm & 2.0 \pm \\ & \\ & \\ & \\ 2.5 \pm & 4.5 \pm\end{array}$

Dendritic and lower members:

5. Clay, silty, and silty sandy. Upper several feet has some thin laminae of fine sand, abundant oolites, ostracodes, some nonplaty tufa nodules. Some segregations of gypsum and (or) other salines. Lacustrine....-

7. $3 \quad 12.5 \pm$

Lower member:

6. Sand, pebbly, and gravel, sandy. Upper $1 \mathrm{ft}$ is interbedded clean medium sand and fine-medium sand with pebbles to $1 / 2$ inch diameter, lower part is sandy gravel with some pebbles more than 1 inch diameter, some gastropod shell fragments. Hole bottomed on cobble or boulder. Lacustrine.......

2. $3 \quad 14.8 \pm$

Section 32

Stratigraphic section at type locality of dendritic member of Sehoo formation. $S 1 \frac{12}{2}$ sec. 17 (unsurveyed), T. 18 N., R. 31 E., near road on east side of Rainbow Mountain and several hundred feet south of 4,160-foot bench mark. Exposed by several trenches, from top of high-shore bar of middle Sehoo lake, down bank of a gully, and by pit dug into bed of gully (fig. 14). Top of section altitude $4,175 \pm 5$ feet.

Dendritic member (bearing Toyeh soil:)

Sand, fine-gravelly, and sand, wellsorted; top $14 \mathrm{in}$. shows complete profile of Toyeh soil (see soil profile 32S). Lacustrine; high-shore-bar deposit of middle Sehoo lake......-

Lower member:

Sand, medium, well-sorted, unconsolidated. Lacustrine

Lower member (transgressive part) :

Gravel, cobble. Lacustrine 


\section{TABLE 10.-Stratigraphic sections-Continued \\ Section 32-Continued}

Wyemaha formation (bearing Churchill soil):

Gravel, sandy, fine, somewhat clayey and mottled red-brown and gray in upper 1 $\mathrm{ft}$ (oxide horizon of Churchill soil), paleyellow brown in next $1 \mathrm{ft}$, and containing some white soil-lime concretions and coatings; balance is yellow-gray, with some soil lime $\left(\mathrm{C}_{\mathrm{es}}\right.$ horizon of Churchill soil). Alluvial gravel. ...............

Eetza formation:

Gravel, fine, well-sorted, with a little soillime (lower part of $\mathrm{C}_{\mathrm{ea}}$ horizon of Churchill soil). Lacustrine

Gravel, medium, well-sorted, with a little lake tufa cementation. Lacustrine .... Base not exposed.

Section 33

Partial stratigraphic section in louer part of Truckee formation in gulch on north side of hill about $1 / 4$ mile south of Eagles House, in $S E^{1 / 4} S W 1 / 4$ sec. $13, T .18$ N., R. 30 E.; top of section starts about 1,750 feet due east of $S W$ cor. sec. 13, at altitude of about 4,430 feet. (Depth column below indicates cumulative thickness.)

Truckee formation:

Thickness Depth

1. Tuff, silicified, variegated red, gray, buff, and white ("wonderstone"); wellbedded; poorly exposed, forms top of

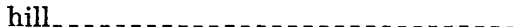

2. Sandstone, oolitic, tuffaceous, generally more sandy than 3 , pink-gray to graypink, hard, well-to massively bedded, some beds ripple-marked; together with oolite below forms cliffs 20 to 30 ft high..............................

3. Limestone, oolitic, with some interbedded tuffaceous calcareous sandstone, gray-pink to gray, hard, wellto massively bedded.

4. Sandstone, tuff aceous, pink, light-gray to tan-gray and greenish-tan-gray; upper $18 \mathrm{ft}$ oolitic and generally calcareous, well-indurated; lower $12 \mathrm{ft}$ soft, though generally somewhat better indurated than $7 \ldots \ldots$

5. Interbedded material like 6 and $7 \ldots$

6. Clay, some soft siltstone, grayish-light red, semi-indurated, thinly bedded.-

7. Sandstone, tuffaceous, soft, semi-indurated; medium-grained sand with silty matrix; probably large percentage of silicic tuff; mostly pale red, especially upper part, with bright-green grains; well bedded. Some silty and clayey beds, especially in lower part, where many beds are gray and greenish gray ..............................

8. Limestone, dense, fine-grained, lighttan-gray . . . . . . . . . . . . .

9. Clay, buff-yellow

Base not exposed-fault cuts off section at base.

$2 \pm \quad 72$

$5 \pm \quad 77$

$35 \pm 112$

.2112 .2

$3 \pm 115.2$

\section{TABLE 10.-Stratigraphic sections-Continued \\ Section 34}

Stratigraphic section at type locality for Churchill soil (see table 12, soil profile 34S) and also for lower member of Sehoo formation and lower tongue of Indian Lakes formation. East bank of wash on west side of Churchill Valley, $75 \mathrm{ft}$ south of small basalt hill in middle of valley, $S E^{1 / 4} S W 1 / 4$ sec. $15, T .18$ N., R. 30 E. Top of section, altitude $4,190 \pm 10$ feet.

Sehoo formation:

Thickness Depth

Lower member (bearing Toyeh soil) :

Sand, medium and fine, limy, very pale yellowish gray; some small pebbles; abundant small snail shells (Parapholyx nevadensis); at base a few heads of coralline tufa (which grew upward in sand from bases attached to cobbles or pebbles in the gravel bed below). Lacustrine. Top 8 in. is weakly cemented by calcium carbonate $\left(\mathrm{C}_{\mathbf{c a}}\right.$ horizon of Toyeh soil, eroded). About $250 \mathrm{ft}$ south, sand contains heads of dendritic tufa of dendritic nember of Sehoo, but the high shore of the middle Sehoo lake is not clearly marked.......... Lower member (transgressive phase):

Gravel, cobble and pebble with sandy matrix; limy; thin lime coatings on roundstones, and uppermost cobbles and pebbles have thin discontinuous coatings of cơralline tufa. Roundstones are all basalt of Bunejug formation. Unit thickens to 5 $\mathrm{ft} 30 \mathrm{ft}$ to the north and there contains some small boulders.........

Sand, medium, white to light-gray (10YR 8/1 to $10 Y R 7 / 1)$; very clean almost no pebbles or silt; very incoherent, except somewhat cemented with calcium carbonate in

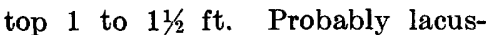
trine ............................

Indian Lakes formation:

Lower tongue:

Sand, medium, with some pebbles and cobbles; light-tan-gray; slightly indurated; probably alluvial. ........

Sand, medium, with some pebbles and cobbles, especially at base; brightyellow-tan; moderately coherent; some weak calcium carbonate concentrations. Alluvial. Thickens to $5 \mathrm{ft}, 30 \mathrm{ft}$ to the south

4 4

Sharp contact, dips about $10^{\circ} \mathrm{S}$.; slight disconformity.

Wyemaha formation (bearing Churchill soil) :

Sand, medium, with a few pebbles, cobbles, and angular rock fragments in uppermost $1 \mathrm{ft}$. Grains mostly frosted. Eolian. Top $4 \mathrm{ft}$ bears Churchill soil, which is exceptionally well preserved
$2.5 \quad 18.5$

1. $5 \quad 20$ 
TABLE $_{\text {10.-Stratigraphic sections-Continued }}$

Section 34-Continued

Wyemaha formation-Continued

here (see soil profile 34S). Upper few

Thickness Depth $($ feet $) \quad($ feet $)$

feet of sand partly indurated by soil development, lower part of sand is unconsolidated. Mostly parallel bedded, dipping several degrees southward; locally crossbedded. Base of sand not exposed here, but about $60 \mathrm{ft}$ to north it overlies boulder gravel of Eetza formation.......

\section{Section 35}

NE1/4 sec. 17, T. 18 N., R. 30 E. Stratigraphic section exposed in bank of drainage canal and 5-foot auger hole in flat near former course of Stilluater Slough. Top of section, altitude 3,924 3 feet.

Fallon formation:

$\begin{array}{cc}\text { Thickness } & \text { Depth } \\ \text { (feet) }\end{array}$

Second lake unit:

1. Sand, fine-medium, light-tan-gray, uncemented, clean, parallelbedded. Lacustrine.

First lake unit:

2. Clay, silty and sandy, brown, many snail shells. Lacustrine

3. Sand, fine, gray, some snail-shell fragments; weak calcium carbonate cementation. Lacustrine...

4. Sand, fine-medium, brown. Lacustrine

Turupah formation (bearing Toyeh soil):

5. Sand, fine, eolian, somewhat cemented with calcium carbonate, especially in lower $1 \mathrm{ft}\left(\mathrm{C}_{\mathrm{os}}\right.$ horizon of Toyeh soil) ........

6. Sand, fine and fine-medium, relatively uncemented. Eolian....

Disconformity.

Sehoo formation:

Upper member:

7. Clay, brown, many snails. Lacustrine

Disconformity.

Dendritic member:

8. Clay, greenish-gray; top several feet darker and somewhat carbonaceous. Lacustrine........

Thinolite unit(?) :

9. Clay, lean, rust-colored, and with light-gray limy segregations. Lacustrine.

10. Clay, lean, greenish-gray, with small crystals and crystal aggregates of thinolite and small rounded tufa nodules; some ostracode coquina partings, commonly showing rusty staining. Lacustrine

$.5 \quad 14.7$

Lower member:

11. Clay, olive-green-gray. Lacustrin

Base not reached.
$\mathbf{T}_{\mathrm{ABLE}}$ 10.-Stratigraphio sections-Continued

\section{Section 37}

NE cor. sec. 20, T. 18 N., R. 29 E. Top of section, altitude 3,940 feet. Carson River flood plain. Stratigraphic section exposed in drainage canal bank, and 5:5-foot auger hole.

Fallon formation:

First lake unit:

1. Sand, coarse, medium, and fine, moderately well to poorly sorted, light-tan-gray to locally dark-gray; mostly rather lenticular parallelbedded, but some smallscale crossbedding near base. Lacustrine

Sharp contact, undulating; minor disconformity.

2. Sand, fine, and very fine, grading downward to silt; some irregular tufa nodules and gypsum(?) segregations; iron stains; at base, 1 in. of medium sand, very dark gray. Lacustrine.........

3. Sand and silt, interbedded, parallel bedded. At top, 0.5-1 ft of silty coarse to fine sand, poorly sorted, medium-gray; then about 2 in. tan-gray silt; then 3-4 in. fine-medium sand, clean, loose; then about 4 in. bluegray to light-tan-gray silt, and silty clay. Some iron stains, abundant gypsum segregations, slight salty taste. Lacustrine.......-

Sharp contact, possible minor disconformity.

4. Silt (very fine sandy to slightly clayey); top 0.3-0.5 ft dark gray to nearly black, due to carbonaceous matter, and sandy; remainder tan gray and better sorted; some interbeds of fine sand in lower part. A few gypsum segregations, iron stains. Lacustrine ..............

. 314.2 Sharp contact, possible disconformity. Turupah formation:

5. Sand, coarse and medium, local lenses of fine-pebbly coarse to medium sand, clean, uncemented (loose); pebbles rarly to $1 / 2$ in. diameter (typical Carson River assemblage). Top 3 in. locally well cemented. Alluvium (Carson River channel $\begin{array}{cc}\text { Thickness } & \text { Depth } \\ \text { (feet) }\end{array}$ 
TABLE 10.-Stratigraphic sections-Continued Section 37-Continued

Sehoo formation:

Upper member:

$\begin{array}{cc}\text { Thickness } & \text { Depth } \\ (\text { feet }) & \text { (feet) }\end{array}$

6. Clay, gray-brown, fatty, compact; iron stains, some carbonaceous matter (black stains). Lacustrine . ......

7. Sand, fine, clean, gray-brown. Lacustrine ............... .

8. Sand, medium, clean, graybrown. Lacustrine

9. Sand 2. 0

Section 39

Floor of Hidden Cave, on north side of Eetza Mountain, SW1/4 sec. 21, T. 18 N., R. 30 E. Stratigraphic section exposed in west wall of pit N6 dug in 1951 by California University and U.S. Geol. Survey archaeologic field party (Grosscup, 1956). Top of section, altitude 4,103 feet.

Fallon formation:

Upper member equivalent:

$\begin{array}{ll}\text { Thickness } & \text { Depth } \\ (\text { feet }) & \text { (feet) }\end{array}$

1. Silt, some very fine and fine sand; light-gray. Eolian; sparse pebble-size angular fragments of red basalt and tufa, probably roof fragments; well-bedded, beds thin and parallel; somewhat coherent, tends to form soft blocky fragments; thickness somewhat variable, due to deposition over irregular surface sloping slightly toward interior of cave; top surface originally was almost level.

Second lake unit equivalent:

2. "Top midden"; rat and bat guano, with abundant Typhetum (cattail) leaves, some clam shells, a few feathers, and Lovelock (cultural) Phase, of Heizer (1951) artifacts and occupation debris. Over 85 percent of artifacts recovered from the cave in 1951 came from this bed.-

First interlake unit equivalent:

3. Silt and fine sand, poorly sorted, with many angular rock fragments; probably slope wash. Local guano parting, 0.1 to 0.5 in. thick, about 7 in. below top. Rather constant sandy silt (eolian?) layer about $0.2 \mathrm{ft}$ thick in middle of unit, with dark-brown staining and local midden
TABLE 10.-Stratigraphic sections-Continued Section 39-Continued

Fallon formation-Continued Thickness ( feet)

First interlake unit equivalentContinued parting at top. Sparse artifacts, of Lovelock phase

4. Silt and fine sand, wellbedded, bedding thin and parallel. Probably eolian . $2 \pm$

First lake unit equivalent:

5. "32-inch midden." One or more midden layers, interstratified with silt and fine sand (eolian?) and with rocky silt (slope wash) layers. Continuous midden $0.2 \pm 0.15 \mathrm{ft}$ thick at top; several discontinuous local midden partings below. Midden consists of rotted bat guano, plant matter (tule, cane, and cattail); has numerous artifacts of the Lovelock Phase of Heizer (1951) ...

Turupah formation:

6. Silt and fine sand, pale-gray, evenly and horizontally bedded (loess), with local lenticular layers of gravelly silt (slope wash); latter increase in proportion toward cave portal; $3 / 4$-in. discontinuous midden parting in middle. Unit thickens to more than $3 \mathrm{ft}$ in east wall of pit and there contains a white pumiceous ash parting, $1 / 4$ to $1 / 2$ in. thick, several inches above base. Two obsidian points obtained from upper part of unit...................

Indian Lakes formation (late Sehoo correlative:

7. Gravel, coarse to fine, poorly sorted, much interstitial sand and silt, many blocks and boulders, some $1.5 \mathrm{ft}$ in diameter. Slope wash. Thickens to more than $1 \mathrm{ft}$ in east wall of pit. Local discontinuous rotted guano partings. Many bones of small mammals and birds. Four projectile points assigned to the Hidden Cave (cultural) Phase by Grosscup (1956) _. . . . . . . . . 9 土 
TABLE 10.-Stratigraphic sections-Continued

Section 39-Continued

Sehoo formation:

Dendritic member (regressive phase):

8. Gravel, very fine pebble. Lacustrine. Well sorted (little interstitial sand or silt), uncemented. Thickens to about $1 / 2 \mathrm{ft}$ at east wall of pit, and here is underlain by $0.6 \mathrm{ft}$ of lake sand. Barren of artifacts.

Dendritic member:

9. At top, half a foot of massive lacustrine limestone, white; smooth upper surface, dips about $15^{\circ}$ E., flattening to less than $5^{\circ}$ at east wall of pit. Wellbedded, strata about 1 in. thick, thinning eastward; many fish bones. In lower several inches thinly bedded brown lake clay alternates with partings of white, soft, lacustrine limestone; this part becomes increasingly clayey eastward. Barren of artifacts

Indian Lakes formation:

Middle tongue:

10. Gravel, coarse, very poorly sorted, containing angular blocks and boulders as much as 18 in. but mostly less than 6 in. diameter, with some interstitial sand and silt; slightly cemented with calcium carbonate. Slope wash. Barren of artifacts. Yielded a block of cellular tufa (of the lower member of the Sehoo). Thins rapidly eastward to $0-0.1 \mathrm{ft}$ thick at east wall of pit..................

Sehoo formation:

Lower member (regressive phase):

11. Lake sand, pebbly, clean, uncemented; no artifacts...

Lower member (high-level phase) :

12. Lake clay, silt and silty fine sand. Top third is faintly laminated brown clay; middle third is brown silt; lower third, brown silty fine sand. Clay is slightly gypsiferous. Nearly uniform in thickness over pit floor, but dips several degrees westward. Upper

TABLE 10.-Stratigraphic sections-Continued

Section 39-Continued

$\begin{array}{cc}\text { Thickness } & \text { Depth } \\ \text { (feet) } & \text { (feet) }\end{array}$

$.1 \quad 5.7 \pm$

$.96 .6 \pm$

1. $7 \quad 8.3 \pm$

$.1 \quad 8.4 \pm$

Base not exposed.

Sehoo formation-Continued

Lower member-Continued surface broken by deep gaping cracks, probably desiccation cracks, and these are filled by gravelly sand from bed 11 . A bird bone found in one of the cracks..................

Lower member (transgressivephase) :

13. Lake gravel, pebble and cobble. Roundstones locally derived, mainly of red volcanic breccia and black andesite similar to that in walls of Hidden Cave and exposed in slopes above the cave. Uncemented.

$\begin{array}{cc}\text { Thiokness } & \text { Depth } \\ \text { (feet) }\end{array}$

$1.3 \quad 9.7 \pm$

$1+\quad 10.7 \pm$

Section 40

$S E 1 / 4 S W 1 / 4$ sec. 21, T. 18 N., R. 30 E. Stratigraphic section exposed in bluff at head of main gulch in Eetza Mountain, east of Hidden Cave. Top of section, altitude 4,224 feet, is crest of a Lake Lahontan bar built across divide between bedrock ridges to the east and west.

Sehoo formation:

Lower member (regressive phase, bearing Toyeh soil):

1. Gravel, coarse, fairly clean, mostly pebbles and cobbles of Bunejug formation; also some of cellular tufa; some have waterworn coatings of lithoid tufa (reworked from unit 3). Lacustrine. Top 1 to $1 \frac{1}{2} \mathrm{ft}$ bears Toyeh soil..........

Lower member (transgressivephase) :

2. Cellular tufa in place (irregular layer). Lacustrine. $\begin{array}{cc}\text { Thiokness } & \text { Depth } \\ \text { (feet) } & \text { (feet) }\end{array}$

$3 \pm 1 \quad 3 \pm$

$5 \pm \quad 3.5 \pm$

3. Gravel, coarse, many cobbles to 10 in. diameter; matrix of fairly well sorted medium gravel; coated and cemented with lithoid tufa, especially in upper part. Lacustrine. Unit thins rapidly southwestward from crest of bar.....

4. Gravel, medium, with a few cobbles. (Base of unit poorly exposed.) ........

5. Gravel, coarse, with some small boulders to $1 \mathrm{ft}$. No tufa coatings except very thin discontinuous white ones that may be secondary. Lacustrine. -
1. $5 \pm \quad 5 \pm$

$2.5 \pm \quad 7.5 \pm$

$3 \pm \quad 10.5 \pm$ 
TABLE 10.-Stratigraphic sections-Continued

\section{Section $40-$ Continued}

Sehoo formation-Continued Lower member-Continued

6. Gravel, medium, with some cobbles (poorly exposed). Lacustrine.......................

7. Gravel, boulder, many boulders more than $1 \mathrm{ft}$ diameter. Lacustrin

8. Granule-sand and fine gravel, well-cemented by lithoid tufa. Lacustrine . . .

9. Gravel, coarse and medium, interbedded. Coarse layers contain cobbles and small boulders to about $1 \mathrm{ft}$ diameter. Some lithoid tufa coatings on roundstones, but evidently reworked, not deposited in place. Lacustrine...........

10. Gravel, medium, sandy, especially in lower part. Lacustrine

Disconformity.

Wyemaha formation (bearing Churchill soil, eroded):

11. Sand, fine-medium and medium, mostly pale-yellowish gray. Eolian. Top 10 in. (locally eroded) is B horizon of Churchill soil, light yellowish brown (10YR 6/4) sandy loam, weak prismatic, hard, noncalcareous; next 12 in. is $B_{o s}$ horizon, light-yellowish-brown (10YR 6/4), massive, slightly hard, with weak irregular calcium carbonate concentration; next $20 \pm$ in. is $C_{o a}$ horizon, very pale brown (about 10YR 7/4) to white, massive, hard to locally slightly hard, with strong to locally moderate calcium carbonate concentration; next $18 \mathrm{in}$. is lower part of $\mathrm{C}_{\mathrm{oa}}$ horizon, very pale brown to locally white, massive, slightly hard to locally hard, with irregular strong, moderate, to weak calcium carbonate concentration; the underlying sand, below the soil, is unconsolidated, single-grain, and loose. The stronger calcium carbonate concentration occurs in whitish streaks, irregular bodies, and some cylindrical bodies $1 / 8$ to 1 in. diameter (apparently precipitated around former roots) .........

$40+\quad 65 \pm$

Nore.-Several units vary considerably in thickness within short distances; the thicknesses cited are averages in the line of
$.5 \pm \quad 17 \pm$

$5 \quad 22 \pm$

$3 \quad 25 \pm$
TABLE 10.-Stratigraphic sections-Continued

section. The contact between the Wyemaha formation and gravel of the Eetza formation is well exposed in several small tributary gulches within a quarter of a mile to the southwest.

\section{Section 41}

$S E 1 / 4$ sec. 21, T. 18 N., R. 30 E. Stratigraphic section exposed in bank of small gully at southwest side of saddle at west end of Wyemaha Valley (pls. 7 and 8). Top of section altitude about 3,996 feet. Lower 2 feet is dug pit.

Sehoo formation:

Dendritic member:

Base not reached.

Gravel, very fine, well-sorted; top several inches densely cemented by lithoid tufa, weathers to slabs. Lacustrine . . .....................

Disconformity, representing subaerial exposure.

Thinolite unit(?) (bearing incipient unnamed soil) :

Clay, silty, grading to silt, clayey silt and fine sand in lower part. Calcium carbonate nodules and platy partings locally at top and near base, drusy-crystalline tufa nodules at base (no definite thinolite seen, however). Lacustrine. Top several inches are weathered and show incipient soil development-clay is checked, stained rusty red-brown, and has some white soil-lime concentration

Lower member:

Gravel, fine, well-sorted, uncemented, most pebbles under 1 in., maximum size $1 \frac{1}{2}$ in. Lacustrine...........

Sand, medium, with some coarse sand and granules, a few small pebbles; uncemented. Lacustrine _...... 1.2 7.5士

Gravel, cobble. Lacustrine ......... . .5 $8.0 \pm$

\section{Section 42}

SE1/4 sec. 21, T. 18 N., R. 30 E. Stratigraphic section exposed in bank of large gully at southwest side of saddle at west end of Wyemaha Valley (pls. 7 and 8). In type area of Wyemaha and Sehoo formations. Top of section, altitude about 4,012 feet.

Sehoo formation

Dendritic member (bearing Toyeh soil):

Gravel. Medium gravel in top $1 \mathrm{ft}$ and bottom $1 \mathrm{ft}$, remainder is granule sand, very well sorted, with some small pebbles. Many waterworn fragments of dendritic tufa. Lacustrine. Top $1 \mathrm{ft}$ bears Toyeh soil. ..........

Disconformity.

Lower member (bearing incipient unnamed soil, eroded):

Silt, clayey, and silt, very limy. Top appears weathered (incipient soil development, somewhat eroded). Mainly silt in lower 3. $0 \pm \quad 3.0 \pm$

$\begin{array}{cc}\begin{array}{c}\text { Thickness } \\ (\text { feet })\end{array} & \begin{array}{c}\text { Depth } \\ \text { (feet) }\end{array} \\ \text { 3. } 0 \pm & 3.0 \pm\end{array}$

\section{2. $0 \quad 5.0 \pm$}

$\begin{array}{cc}\text { Thickness } & \begin{array}{c}\text { Depth } \\ \text { (feet) })\end{array}\end{array}$

$7 \pm \quad 7 \pm$ 
TABLE 10.-Stratigraphic sections-Continued

\section{Section 42-Continued}

Sehoo formation-Continued

Lower member-Continued

part. Limestone parting at base. Lacustrine

Sand, very fine, and fine, with some very fine sandy silt in middle; ostracodes. Lacustrine..........

Sand, pebbly, medium. Lacustrine . ..........................

Gravel, medium, and medium sand.

Lacustrine........................

Disconformity.

Wyemaha formation (bearing Churchill soil, eroded):

Sand, fine-medium and medium, paleyellow-gray, somewhat crossbedded.

Eolian. Partly indurated, with irregularly disseminated white soil-lime concentrations, commonly along bedding and joints (eroded $\mathrm{C}_{\mathrm{ea}}$ horizon of Churchill soil)

Base not exposed.

\section{Section 43}

$S E_{1 / 4}^{1 / 4}$ sec. 21, T. 18 N., R. 30 E. Stratigraphic section exposed in bank of large gully at southwest side of saddle at west end of Wyemaha Valley (pls. 7 and 8). In type area for Wyemaha and Sehoo formations. Top of section, altitude about 4,045 feet.

\section{Sehoo formation:}

Dendritic member (bearing Toyeh soil):

Gravel and pebbly sand. Top $2 \mathrm{ft}$ is very fine gravel and granule sand with some pebbles over $1 \frac{1}{2}$ in.; middle part, coarse sand and grit with some small pebbles, well sorted and uncemented; lower $2 \mathrm{ft}$ is sandy medium gravel grading to clean medium gravel at base. Many waterworn fragments of dendritic tufa throughout. Lacustrine. Top $1 \mathrm{ft}$ bears Toyeh soil . . . . . .

Disconformity.

Dendritic member:

Silt and sandy silt, a little clayey silt, very limy, with platy limestone partings. Limestone parting 1 to 2 in. thick at base cements top of underlying gravel. Lacustrine.......................

Dendritic and lower members:

Gravel, medium, grading to cobble gravel at base. Many "wonderstone" pebbles in upper part, few in lower. Lacustrine. The lower (cobble) gravel, traced northeast (along lake bar), is separated from the upper gravel by a 1 -to-1 $1 / 2-\mathrm{ft}$ sand layer; also the lower gravel coarsens and roundstones are almost entirely from Bunejug for-

$\begin{array}{cc}\text { Thickness } & \text { Depth } \\ \text { (feet) } & \text { (feet) }\end{array}$

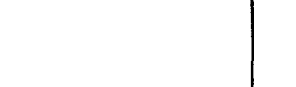

8.58 .5

1. $3 \pm \quad 9.8 \pm$

$\mathrm{T}_{\mathrm{ABLE}}$ 10.-Stratigraphic sections-Continued Section 43-Continued

Sehoo formation-Continued

Dendritic and lower members-Con. mation, indicating derivation from shore drift from northeast. Derivation of upper gravel (and its "wonderstone" pebbles) is unknown. Lower gravel is lower member; upper gravel probably is dendritic member.........

Lower member:

Pebbly medium sand. Lacustrine _ $\quad$. $5 \quad 12.3 \pm$ Disconformity.

Wyemaha formation (bearing Churchill soil, eroded):

Sand, fine-medium and medium, paleyellow-gray, somewhat crossbedded. Eolian Semi-indurated, especially in upper several feet, because of calcium carbonate cementation by $\mathrm{C}_{\mathrm{oa}}$ horizon (eroded) of Churchill soil..........17 $\underset{\text { (feet) }}{\text { Thickness }} \begin{aligned} & \text { Depth } \\ & \text { (feet) }\end{aligned}$

\section{$2.0 \quad 11.8 \pm$}

Base not exposed.

Section 44

$S E 1 / 4$ sec. 21, T. 18 N., R. 30 E. Stratigraphic section exposed in bank of large gully at southwest side of saddle at west end of Wyemaha Valley (pls. 7 and 8). In type area for Wyemaha and Sehoo formations. Top of section, altitude about 4,046 feet.

Sehoo formation:

Dendritic member:

Dendritic tufa "heads" in place, to

$\begin{array}{cc}\text { Thickness } & \text { Depth } \\ \text { (feet) } & \text { (feet) }\end{array}$ 1-ft. diameter. Lacustrine.......

Silt, sandy, and fine sand, limestone partings. Lacustrine..........

Dendritic and lower members:

Sand. Lacustrine ..............

Lower member:

Gravel, very sandy, cobble. Lacustrine .......................

Disconformity.

Wyemaha formation (bearing Churchill soil, eroded):

\section{$0.5 \pm \quad 0.5 \pm$ \\ 1. $0 \pm \quad 1.5 \pm$ \\ 1. $53.0 \pm$}

1. $0 \pm \quad 4.0 \pm$

6. $0 \pm \quad 10.0 \pm$

Eetza formation:

Gravel, medium, well-sorted. Lacustrine .............................

Gravel, boulder. Lacustrine.........

Paiute formation (bearing Cocoon soil, eroded):

Gravel, boulder, poorly sorted, bearing somewhat eroded Cocoon soil. In top several inches the interstitial fines are reddish brown, somewhat clayey, and nearly free of ealcium carbonate-the $B_{c a}$ subhorizon of this soil ; beneath is dense caliche-the top of the $\mathrm{C}_{\mathrm{ca}}$

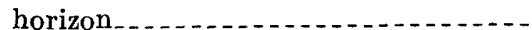

Base not exposed. $\begin{array}{rr}.5 \pm & 10.5 \pm \\ 1.0 \pm & 11.5 \pm\end{array}$

1. $5 \quad 13.0 \pm$ 
$\mathrm{T}_{\mathrm{ABLE}}$ 10.-Stratigraphic sections-Continued

Section 45

$S E Y_{4} N E Y_{4}^{4}$ sec. $21, \quad T .18$ N., R. 30 E. Generalized stratigraphic section exposed in bank of large gulch on north side of saddle between Eetza Mountain and Sehoo Mountain (west end of Wyemaha Valley). In type area for Wyemaha and Sehoo formations. Top of section, altitude 4,020 \pm 10 feet.

Sehoo formation:

Dendritic member (bearing Toyeh soil):

1. At surface, $1 / 2$ to 1 in. small pebbles and grit (lag gravel). Underneath is $31 / 2$ in. sandy silt, slightly calcareous, with some granules and pebbles, having prominent vesicular structure (vesicular horizon of Toyeh soil). Balance is granules and fine gravel with some water-rounded fragments of dendritic tufa; upper $4 \mathrm{in}$. is slightly oxidized and leached of calcium carbonate and grades into 8- to 11-in. horizon showing moderate soil-lime accumulation ( $B$ and $\mathrm{C}_{\mathrm{oa}}$ horizons of Toyeh soil). Lacustrine . . . . . . . .

Dendritic and lower members:

2. Sand, medium and fine, and silt, highly calcareous, with many partings cemented by calcium carbonate and several partings (generally $1 / 2$ to $1 \mathrm{in}$. thick) of nearly pure limestone. Abundant ostracods and snail-shell fragments. Top $1 / 2 \mathrm{ft}$. contains many water-rounded fragments of dendritic tufa. Lacustrine...

Disconformity.

Lower member:

3. Gravel, coarse cobbly, with sand; well-rounded roundstones of basalt; locally dips about $10^{\circ}$ (lake bar). Lacustrine . ............

4. Sand, medium to fine-medium, clean, with a few small pebbles; evenly bedded; some ostracods. Lacustrine

Disconformity.

$\begin{array}{ll}\text { (feet) } & \text { Depth } \\ \text { (feet) }\end{array}$

(feet)

Base not exposed.

TABLE 10.-Stratigraphic sections-Continued

\section{Section 45-Continued}

Wyemaha formation-Continued

5. Sand-Continued

than $1 / 8$ in. diameter), and probably were precipitated about former roqts. Calcium carbonate concentration decreases irregularly downward; lower beds commonly are poorly indurated.

Thickness Depth

feet)

$$
\text { Section } 45 a
$$

SW1 $/ 4 N W 3 / 4$ sec. 22, T. $18 N .$, R. 30 E. Stratigraphic section exposed in southeast wall of 1952 gravel pit on north side of saddle between Sehoo and Eetza Mountains, at west end of Wyemaha Valley. Top of section (former land surface), altitude about 4,080 feet. Shown in figure 15c.

Sehoo formation:

Dendritic member (bearing Toyeh soil):

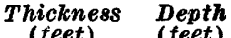

Sand, fine, with some small pebbles; pale-tan-gray; very limy; abundant dendritic tufa in "heads" commonly more than $1 \mathrm{ft}$ diameter and about 1-ft high, which grew upward from gravel bed below. Upper several inches ( $\mathbf{B}$ horizon of Toyeh soil) darker and browner than material beneath. Lacustrine

(feet) (feet)

1. $3-2 \quad 1.5 \pm$

2-4 4. 5 士

Dendritic member:

Gravel, cobble, with some small boulders to $1-\mathrm{ft}$ diameter, and some pebbles and sand in matrix; roundstones are all basalt of the Bunejug formation; heavily coated with calcium carbonate in top $1 / 2$ to $1 \mathrm{ft}$ (just below dendritic tufa layer), next $1 / 2$ to $1 \mathrm{ft}$ is almost free of calcium carbonate; next $1 \mathrm{ft}$ has heavy (lithoid tufa) coatings, and one boulder coated with coralline tufa (reworked from a bar of gravel of sand; well-sorted; relatively non-
Wyemaha formation (bearing Churchill soil, eroded):

5. Sand, fine-medium to medium, wellsorted, pale-yellow-gray; evenly bedded (not crossbedded); bedding about flat, or dips $1^{\circ}-2^{\circ}$ downslope (NW). No fossils. Sand is almost entirely quartz grains, well-frosted. Eolian. Upper several feet are partly indurated by soil-lime cementation, with irregularly dispersed whitish calcium carbonate segregations, especially along bedding planes, joint cracks, and as dispersed cylindrical bodies $1 / 4$ to $3 / 4$ in. diameter; latter have hollow centers (generally less lower member $30 \mathrm{ft}$ to west). Lacustrine

Gravel, fine-pebble, to coarse grit limy, slightly indurated. Lacustrine - sightly indurated. Lacus-

1. $56 \pm$

Indian Lakes formation:
Middle tongue:

Sand, fine, somewhat silty and gravelly; with variable amounts of pebbles (mostly small), cobbles, and locally, small boulders; very limy, with some calcium carbonate root "casts"; poorly sorted; indistinctly bedded; variable in thickness and discontinuous, but can be traced around three sides of this gravel pit; pinches out $20 \mathrm{ft}$ to west. Possible very weak soil development in uppermost several inches. Colluvium (slope wash) .................
2<smiles>[131IH]</smiles>

14

$1.5 \quad 5.5$ 
TABLE 10.-Stratigraphio sections-Continued

Section 45a-Continued

Sehoo formation:

Lower member:

Gravel, coarse; mostly lenses of smallboulder and cobble gravel; some pebble-gravel beds, generally fairly well sorted, with little interstitial sand. Upper part very limy. About $35 \mathrm{ft}$ to west thickens to $7 \mathrm{ft}$ and upper $3 \mathrm{ft}$ is cemented by lithoid tufa and topmost roundstones bear coatings of coralline tufa. Lacustine.

Sand, mostly medium, well-sorted, some lenses of small-pebble sand; limy; well-indurated. Lacustrine..

Sharp contact; small disconformity.

Wyemaha formation (bearing Churchill soil, eroded):

Sand, silty, gravelly, in upper part (poorly sorted, with some pebbles, rare cobbles, and small boulders); grades downward to sandy coarse gravel in lower part. Colluvium (slope wash). Bears a strong soil (Churchill soil); B horizon is mostly eroded-top 3 to 4 in. is $B_{c a}$ horizon, grayish-brown with some calcium carbonate concentration, remainder of unit is $\mathbf{C}_{\mathrm{ca}}$ horizon, with strong concentration of calcium carbonate, causing much white mottling; $\mathrm{C}_{\mathrm{ca}}$ horizon extends about $2 \mathrm{ft}$ into underlying gravel .....

Small disconformity.

Eetza formation:

Gravel, coarse-small boulders and cobbles in matrix of pebble gravel, with a local lens of small-pebble gravel; roundstones all basalt of the Bunejug formation; many of them are more or less "rotten"; those in upper $2 \mathrm{ft}$ are strongly to moderately calcium carbonate (lithoid tufa) coated, in next $2 \mathrm{ft}$ have only weak coatings. A probable very weak soil lies $31 / 2 \mathrm{ft}$ below top of unit-2 to $3 \mathrm{in}$. suggestive of very weak oxide horizon, underlain by several inches with very weak soil-lime concentration (noted $\mathrm{C}_{0 \mathrm{a}}$ horizon). Lowermost $1 \mathrm{ft}$ is entirely free of calcium carbonate, unconsolidated, with matrix of black basaltic medium sand. Crudely stratified; beds dip several degrees eastward; apparently are part of a spit or bar. Lacustrine..-

Base not exposed.
TABLE 10.-Stratigraphic sections-Continued

Section 47

400 ft south of 144 sec. cor. between secs. 28 and $29, T .18 N ., R$. 29 E. Carson River flood plain. Stratigraphic section exposed in drainage canal bank, and 4-foot auger hole. Top of section, altitude 3,927 feet.

Fallon formation:

Second lake unit:

Sand, fine, light-tan-gray, clean, thinly bedded; beds dip north ward as much as $20^{\circ}$. Coherent. Bottom 1-3 in. clean medium sand, grading to clean coarse sand. Alluvial and lacustrine (deltaic)

$1.4 \quad 1.4$

Disconformity.

First lake unit:

Clay, chocolate-brown to light-brown (darkest and iron-stained at top); grades more fatty downward. Lacustrine . . . . . . . . . . . . . . . . .

4. $9 \quad 6.3$

First lake unit or Turupah formation:

Sand, medium, clean, blue-gray, grading downward to orange-tan gray. Alluvial or lacustrine.............

2. $0 \quad 8.3$

Turupah formation:

Sand, medium, some pebbly coarse. Alluvial . . . . . .

$4+\quad 12.3$

Base not exposed.

\section{Section 48}

East edge sec. 32, T. 18 N., R. 29 E. Carson Lake plain. 1.512 Stratigraphic section exposed in drainage canal bank, and 3 -foot auger hole. Top of section, altitude 3,921 feet.

Fallon formation:

Third lake unit:

Sand, medium and coarse, poorly to moderately well-sorted. Lacustrine.

Disconformity.

Second lake unit:

Silt, clayey, very dark gray, carbonaceous. Lacustrine

0. 3-0. $5 \quad 2 \pm$

First interlake unit:

Sand, medium, clean, light-tan-gray; very lenticular (low moundlike deposits). Eolian..................

Sharp contact, disconformity.

First lake unit:

Clay, dark-drab-gray. Lacustrine.-.

Sand, fine, dark-gray, carbonaceous. Thickness
$($ feet $)$$\quad \begin{gathered}\text { Depth } \\ \text { (feet) }\end{gathered}$

1. $5 \quad 1.5$

Turupah formation:

Sand, coarse pebbly, pebbles to $1 / 2$ in. diameter (typical Carson River assemblage).

6. 518.5 Alluvium (Carson River channel sand) - -

Base not exposed.

$\begin{array}{cl}\text { Thickness } & \text { Depth } \\ \text { (feet) } & \text { (feet) }\end{array}$ th 
TABLE 10.—Stratigraphic sections-Continued

Section 49

NE cor. sec. 34, T. 18 N., R. 29 E. Stratigraphic section exposed in bank of drainage canal in Carson Lake plain. Top of section, altitude 3,919 feet.

Fallon formation:

Young lake and interlake unit:

Sand, fine, with small calcium carbonate nodules. Lacustrine...........

Sand, silty, fine, saline. Lacustrine - -

Sand, very fine, micaceous. Alluvial (Carson River channel sand) ......

Sand, fine, with small clay pellets; nearly black, micaceous. Alluvial..

Disconformity.

Third lake unit:

Clay, black. Lacustrine...........

Second interlake unit:

Sand, medium, clean. Lacustrine or alluvial

\section{Section 50}

SW1/4 sec. 36, T. 18 N., R. 30 E. Northeast bank of gravel pit in gravel bar at base of mountain slope, near Salt Wells. Top of section, altitude 3,990 5 feet.

Sehoo formation:

Upper member (bearing Toyeh soil, eroded) :

1. Sand, fine-medium, silty and gravelly; pale-tan-gray. Lacustrine. Lag gravel of pebbles and small cobbles at surface. Very limy (eroded calcareous horizon of Toyeh soil) _...........

2. Same as 1, but less sandy; mostly poorly sorted coarsemedium gravel, with moderate soil-lime concentration. Lacustrine........

3. Sand, pebbly coarse-medium, moderately well sorted; very limy (soil-line). Thickens to $1 \frac{1}{2} \mathrm{ft} 200 \mathrm{ft}$ to west.

Upper member: Lacustrine..............

4. Sand, pebbly coarse-medium, poorly sorted, very limy, pale tan-gray (nearly white). Thickens to west. Lacustrine

Sharp contact, disconformity.
5. Tufa, platy lithoid, coating and cementing medium gravel (some pebbles to 3-4-in. diameter); palegray, nearly white, locally with reddish tinge, probably early lithoid tufa of upper member. On south side of gravel pit, diminishes to thin coatings on

$0.2-0.5$

$0.5 \pm$

$.5 \pm$

1. $0 \pm$
TABLE 10.-Stratigraphic sections-Continued

$$
\text { Section 50-Continued }
$$

Sehoo formation-Continued

Upper member-Continued

Thickness

(feet)

Depth pebbles, especially the undersides, in a 2- to 5-in.

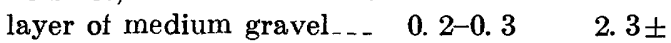

Sharp contact. $\underset{\text { (feet) }}{\text { Thickness }} \quad \begin{gathered}\text { Dept } \\ \text { (feet) }\end{gathered}$

$1.5 \quad 1.5$

1. 0 2. 5

1. $5 \quad 4.7$

$.5 \quad 4.5$

1. $0 \quad 5.5$

$1+\quad 6.5$
Dendritic member:

6. Gravel, very fine, and granule sand, coarsens downward; fairly clean, slightly cemented by lithoid tufa; 10-25 percent dendritictufa fragments; remainder are basalt, andesite, silicified tuff, and rhyolite. Lacustrine............... 1-1.5

$3.5 \pm$

Sharp contact.

Lower member (transgressive phase):

7. Gravel, cobble to medium, overlain by persistent 1 - to 2-in. layer of cellular and lithoid tufa in place. Lacustrine

8. Gravel, very fine, clean, heavily cemented by lithoid tufa. Lacustrine...--

9. Sand, silty, fine-medium, lin:y, saline. Lacustrine.-

10. Sand, coarse, interbedded with medium, somewhat pebbly. Lacustrine.....-

11. Gravel, very poorly sorted (sand, pebbles, some cobbles, and a few boulders to more than 1-ft diameter). Lacustrine 0. 5-0. 7

4. $1 \pm$ $2-2.5$

6. $4 \pm$

0. 2-0. 3

6. $7 \pm$

Wyemaha formation (bearing Churchill soil, eroded):

12. Gravel, alluvial, as follows: (a) at top, about $2 \mathrm{ft}$ sandy fine gravel (mostly coarse, medium, and fine sand and granules with very fine gravel, some pebbles to 4 in. diameter); most pebbles angular to subangular; considerable soil-lime concentration (eroded $\mathrm{C}_{\mathrm{ca}}$ horizon of Churchill soil); large percentage of pebbles are surface checked and more or less "rotten"; (b) next $1 / 2 \mathrm{ft}$ cobble gravel; pebbles and cobbles mostly subangular; (c) lower $2 \mathrm{ft}$ similar to (a), but has less sand; mostly grit and very fine gravel. -

Eetza formation:

13. Gravel, boulder (boulders to more than 2 -ft diameter). Lacustrine

$0.4-0.5 \quad 7.1 \pm$

$1 \pm$

8. $1 \pm$
4. $5 \pm \quad 12.6 \pm$

1. $5 \pm \quad 14 \pm$

Base not exposed. 
TABLE 10.-Stratigraphic sections-Continued

Section 53T

Generalized stratigraphic section of Bunejug formation along west side (about 2 miles long) of Bunejug Mountains, secs. 21 and 28, T. 17 N., R. 30 E. (Depth column indicates approximate cumulative thickness.)

Bunejug formation:

Upper unit:

1. Olivine basalt, black, vesicular to fairly dense; almost no interbedded tuff. Weathers brownish-black to purplebrownish-black along joints.

Local unconformity.

Lower unit:

2. In north, either red basaltic(?) tuff-breccia or highly vesicular basalt flow grading downward from black to red. In south, 10 to $15 \mathrm{ft}$ red scoria at top, over 1 to $3 \mathrm{ft}$ white ash, over 15 to $20 \mathrm{ft}$ buffcolored mafic tuff ..........

3. Andesite, basaltic, olive-darkgray, a few plagioclase phenocrysts in aphanitic groundmass with a peculiar silky luster. Thin platy structure, commonly contorted, not parallel to flow. Apparently thins southward..........

4. Basalt or andesite, black, platy; has slight purplish cast. Porphyritic, with minor small phenocrysts of plagioclase, pyroxene, basaltic hornblende, and olivine. Probably absent in north.......

5. In north, mainly red, purplered, and black basaltic(?) scoria; in south, mostly red basalt and red scoriaceous basalt, some purple to black basalt (in middle part) and red to black scoria, with 0 to $5 \mathrm{ft}$ pink tuff at base. Thickens regularly from north to south...--

6. Olivine basalt, black, vesicular and scoria. Absent in north, gradually thickens southward, to $50 \mathrm{ft}$ at extreme southwest edge of mountains....................

7. Main light-colored tuffaceous zone. In north, 15 to $35 \mathrm{ft}$ thick, with about $6 \mathrm{ft}$ lightbuff to pink tuff and tuffaceous gravel at top, remainder gray to nearly white tuffaceous gravel and waterlaid grit,
TABLE 10.-Stratigraphic sections-Continued

$$
\text { Section 53T-Continued }
$$

Bunejug formation-Continued

Lower unit-Continued

$\begin{array}{cc}\text { Thickness } & \begin{array}{c}\text { Approxi- } \\ \text { mate } \\ \text { (feet) }\end{array} \\ \text { depth (feet) }\end{array}$

containing fragments of rhyolitic glass, white pumice, and considerable basaltic andesite or basalt, including red to black scoria. Locally $10 \mathrm{ft}$ olive-green palagonitic tuff at base. At 4,590 peak this unit is abnormally thick and includes, at top, $25 \mathrm{ft}$ pink quartz latite or rhyolite, strongly flow-banded; $20 \mathrm{ft}$ light- to dark-gray perlite; $50 \mathrm{ft}$ white pumiceous tuff and tuffaceous grit, and gravel, with several feet of yellow tuff containing some mafic fragments near base .......................

8. Basic flows, undifferentiated. Black to dark-gray and darkgreenish-gray basalt and (or) andesite flows, commonly somewhat altered..........

Base not exposed.

\section{Section 54T}

Bunejug formation at its type locality. Stratigraphic section exposed on west face of 4,886-foot mountain, Bunejug Mountains, $N E 1 / 4 N E 1 / 4$ sec. 33 and $N W 1 / 4 N W 1 / 4$ sec. 34 (unsurveyed), $T$. 17 N., R. 30 E. (Depth column indicates cumulative thickness.)

Bunejug formation:

Upper unit:

Local unconformity.

Lower unit:
Olivine basalt flows, black, vesicular to fairly dense; almost no interbedded tuff. Weathers brownish black to purple brownish black..............

1. Red basaltic tuff-breccia ...--

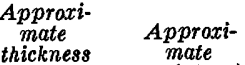

mate

2. Basaltic andesite, olive-darkgray, sparse plagioclase phenocrysts in aphanitic groundmass with silky luster. Thin platy structure, commonly contorted, not parallel with flow . . . . . . . . . . . . . . .

3. Basalt or andesite, dark-gray, platy, slight purplish cast. Sparse plagioclase phenocrysts _.... . . . . . . . . . . . .

4. Tuff-breccia, red, mafic, with some red to purple highly vesicular flows . ............

5. Andesite or basalt, dark-greenish-gray, platy, resembling unit 3. 
TABLE 10.-Stratigraphic sections-Continued

Section 54T-Continued

Bunejug formation-Continued

Lower unit-Continued

6. Tuffaceous zone. Top $15 \mathrm{ft}$ brick-red to purplish tuff; middle part, white to lightgray perlitic and pumiceous tuff, well-bedded as if waterlaid, with some basaltic or andesitic fragments; lower part, light-buff and lightgrayish-buff tuff.

7. Basalt, black to red, red scoriaceous basalt, and red scoria (exposed only in northern part of west face of mountain)

$\left.\begin{array}{cc}\begin{array}{c}\text { Approxi- } \\ \text { mate } \\ \text { thickness } \\ \text { (feet) }\end{array} \text { Approxi- } \\ \text { mate }(f e e t)\end{array}\right)$

Base not exposed.

\section{Section 55}

$S E 144$ sec. 6 (unsurveyed), T. 16 N., R. 31 E. Northeast edge of Cocoon Mountains. Strategraphic section exposed in bank of deep gully (to crest of adjoining ridge). Top of section, altitude $4,280 \pm 20$ feet.

Sehoo tormation:

Lower member:

Thickness Depth

Gravel, fine grades downward to granule sand; sparse snail and ostracode shells; 2 in. medium gravel at top with local cellular tufa in place. Lacustrine

$\begin{array}{rr}3 \pm & 3 \pm \\ 3 & 6 \pm \\ 4 & 10 \pm \\ 6 & 16 \pm \\ 1 & 17 \pm \\ 1.5 \pm & 18.5 \pm \\ 6 \pm & 24.5 \pm\end{array}$

Wyemaha formation:

Sand, medium and fine, pale-yellowish gray. Eolian

$10 \pm 34.5 \pm$

Gravel, boulder, and cobbly pebble. Lacustrine. Base not here exexposed, but unit overlies Bunejug formation about $200 \mathrm{ft}$ downstream

\section{Section 56}

Type locality of Paiute formation and Cocoon soil. Generalized stratigraphic section for several hundred feet along banks of Paiute Wash, about 0.9 mile above where abandoned wagon road from

\section{TABLE 10.-Stratigraphic sections-Continued} Section 56-Continued

Salt Wells to Rawhide crosses this wash, 7.7 miles airline Southeast from Salt Wells, $N E_{1 / 4}^{1 / 4} W_{14}^{1 / 4}$ sec. 8 (unsurveyed) T. $16 \quad N . R$. $31 \mathrm{E}$. Top of section, altitude 4,200 220 feet.

Sehoo formation:

Lower member (bearing Toyeh soil):

Gravel, medium pebble, with some cobbles and a few small boulders (rarely more than $1 \mathrm{ft}$ diameter); bears Toyeh soil. Lacustrine...

Contact generally sharp, locally gradational. Lower member and Wyemaha formation undivided:

Sand, medium, unconsolidated, poorly exposed. Upper part is sand of lower member of Sehoo, disconformable upon local lower part of eolian sand of Wyemaha.........

Sharp contact.

Eetza formation:

Gravel, pebble to boulder, boulders generally less than $1 \frac{1}{2} \mathrm{ft}$; subrounded to subangular, indistinctly bedded; roundstones all of Bunejug formation.

Lacustrine ............................

Local disconformity.

Paiute formation (bearing Cocoon soil):

Gravel, poorly sorted, coarse; boulders (3 ft maximum diameter), cobbles, pebbles, sand, and silt in varying proportions; roundstones mostly subangular to angular, all of Bunejug formation; indistinctly stratified; dips about $1^{\circ}$ to $2^{\circ}$ basinward. In places top several inches have red-brown, clayey matrix, relatively free of calcium carbonate (eroded oxide horizon of Cocoon soil); remainder of thickness is cemented $\left(\mathrm{C}_{\mathrm{ca}}\right.$ horizon of this soil), with dense caliche in upper 4 to $8 \mathrm{ft}$, decreasing below. Base not here exposed, but unit thickens in exposure upstream to locally $30 \mathrm{ft}$ and in places rests disconformably on Bunejug formation.

$\begin{array}{cc}\begin{array}{c}\text { Thickness } \\ \text { (feet) }\end{array} & \begin{array}{c}\text { Approxi- } \\ \text { depth (feet) }\end{array} \\ 2-6 & 4 \pm \\ & \\ 4-8 & 10 \pm\end{array}$

$2-4 \quad 13 \pm$

$10 \pm 23 \pm$

General stratigraphic section of Bunejug formation in central Cocoon Mountains near south edge of Carson Lake quadrangle, sec. 13 (unsurveyed); T. 16 N., R. 30 E. and sec. 18 (unsurveyed), T. 16 N., R. 31 E. (Depth column indicates approximate cumulative thickness.)

Bunejug formation:

Upper unit:

1. Olivine basalt, dark-gray to black, vesicular; commonly six or more flows -

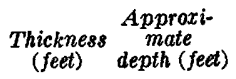

$75-100$ 100

Local angular unconformity.

Lower unit:

2. Tuff, mostly light-gray _........ 15-25 
TABLE 10.-Stratigraphic sections-Continued

\section{Section 57T-Continued}

Bunejug formation-Continued Small angular unconformity.

3. Andesite and(or) basalt flows, dark-gray .........................

4. Tuff, bright-red to pink .........

5. Andesite and(or) basalt flows, dark-gray ........................

6. Tuff, pale-pink to light-gray; poorly exposed . . ...............

7. Andesite and(or) basalt flows, dark-gray

8. Tuff. Upper 10 feet reddish, pink, orange or $\tan$; remainder white or light gray and containing much pumice and light-colored felsite. Locally a few feet of dark-tan tuff at base

9. Andesite and(or) basalt flows, dark-gray to black

Base not exposed.

\section{Section 60}

SE1/4NW14 sec. 13, T. 16 N., R. 28 E. Bank of gully through high gravel embankment at north front of Desert Mountains. Top of section, altitude 4,250 \pm 20 feet.

Sehoo formation:

Lower member:

Gravel, fine, entirely rhyolite pebbles; thickens northward. Lacustrine.

Gravel, fine and medium, entirely rhyolite pebbles, cemented by lithoid tufa with 0 to $1 / 2 \mathrm{ft}$ of cellular tufa at top. Lacustrine.....

Disconformity.

Eetza formation:

Probably regressive shore deposit of second Eetza lake:

Gravel, cobble, with much interstitial fine gravel and coarse sand; 85 percent of roundstones are rhyolite, remainder basalt and andesite; many are subangular. Lacustrine

Probably offshore deposit of second Eetza lake:

Upper fine zone (top to bottom) : 3.5 ft silt, light-gray-yellow; $0.5 \mathrm{ft}$ silty clay, tan; $1.5 \mathrm{ft}$ very fine sand, clean, $\tan ; 1.0 \mathrm{ft}$ silt, $\tan$; $0.5 \mathrm{ft}$ very fine sand, tan. Lacustrine.............................

Probably transgressive shore deposit of second Eetza lake:

Gravel, boulder, with interstitial fine gravel; very angular; entirely rhyolite. Lacustrine or alluvial...

Discomformity.
7. $0 \quad 28 \pm$

$230 \pm$

Table 10.-Stratigraphic sections-Continued

\section{Section 60-Continued}

Eetza formation-Continued

Probably high-stage offshore deposit of Thickness $\begin{gathered}\text { Depth } \\ \text { (feet) }\end{gathered}$ first Eetza lake:

Silt, weak prismatic structure and pale red-brown color suggest incipient soil development. Lacustrine

Sand, very fine, light-tan. Lacustrine.

Probable disconformity (recording subaerial exposure?).

Silt, clayey, silt, and some silty clay, tan-brown, with chocolatebrown staining along irregular prismatic partings, and carbonaceous streaks (root remains?). Lacustrine . . . . . . . . . . . . . . . .

Clay, silty, grayish-brown, with some white gypsum streaks. Lacustrine. . . . . . . . .

Sand, medium, fine, and very fine, interbedded, well-sorted. Lacustrine..........................

Alluvium (?) :

Gravel, fine, angular, practically all rhyolite. Alluvial gravel?......-

Disconformity; probably represents subaerial exposure.

Sand, medium, yellow, pebbly in top $1 / 2 \mathrm{ft}$. Some white limy spots, probably soil lime (possibly incipient soil profile). Lacustrine...........

Gravel, fine, angular, mostly rhyolite.

Base not exposed.

$.5+30.5$ 土

$.5 \quad 31 \pm$

$2 \quad 33 \pm$

$633.5 \pm$

$1.535 \pm$

$2 \quad 37 \pm$

. $637.6 \pm$

$.638 \pm$

Note-The banks of a main wash $1 / 4$ mile to the southwest expose 20 to 85 feet of Eetza formation between altitudes of 4,380 to about 4,200 feet. Unconformably underlying gravel and tufa of lower member of Sehoo formation at an altitude of about 4,300 feet (top of section) are the following sediments of the Eetza, from top to bottom: 20 feet cobble gravel, 15 feet sandy fine- to medium-gravel, a 25foot zone of alternating sand (coarse to fine), silt, and some clean medium gravel (the lower part is mostly sand and fine gravelly sand). The last zone transgresses 5 to 25 feet of coarse boulder gravel that is the basal deposit of the Eetza. The basal gravel can be traced continuously up to the highest shoreline (Lahontan beach), which it underlies.

TABLE 11.-Soil-profile sections in the southern Carson Desert area

$695-3830-64-11$ 
TABLE 11.-Soil-profile sections-Continued Soil profile section $16 \mathrm{~S}-$ Continued

eolian sand of Fallon formation. Vegetation: scattered shadscale (Atriplex confertifolia).

\begin{tabular}{|c|c|c|c|}
\hline $\begin{array}{c}\text { Depth } \\
\text { (inches) }\end{array}$ & $\begin{array}{l}\text { ickness } \\
\text { aches) }\end{array}$ & $\begin{array}{r}\text { Soil } \\
\text { horiz }\end{array}$ & Description \\
\hline . . . & 6 & ..... & $\begin{array}{l}\text { Light-gray (about } 10 Y R 7 / 2 \text { ) coarse eolian } \\
\text { sand; structure, single grain; consist- } \\
\text { ence, loose. (Eolian sand of Fallon } \\
\text { formation, overlying the Toyeh soil.) } \\
\text { Abrupt wavy boundary; minor discon- } \\
\text { formity. }\end{array}$ \\
\hline $0-3$ & 3 & $A^{1}$ & $\begin{array}{l}\text { Light-gray }(10 Y R 7 / 2) \text { sandy loam; struc- } \\
\text { ture, weak vesicular; consistence, hard. } \\
\text { Abrupt, smooth boundary. }\end{array}$ \\
\hline $3-7$ & 4 & $\mathrm{~B}^{1}$ & $\begin{array}{l}\text { Grayish-brown }(10 Y R 5 / 2) \text { sandy loam; } \\
\text { structure, moderate to strong coarse } \\
\text { columnar; consistence, hard. } \\
\text { Clear, smooth boundary. }\end{array}$ \\
\hline $7-11$ & 4 & Cea & $\begin{array}{l}\text { Light-brownish-gray (10YR 5/2) sandy } \\
\text { loam; calcareous, many irregular white } \\
\text { calcium carbonate segregations; struc- } \\
\text { ture, weak coarse columnar to weak } \\
\text { coarse subangular blocky and weak } \\
\text { coarse and very coarse granular; con- } \\
\text { sistence, hard. }\end{array}$ \\
\hline-15 & 4 & $\mathrm{Cca}$ & $\begin{array}{l}\text { Light-brownish-gray (10YR 6/2) loamy } \\
\text { sand; structure, weak coarse columnar to } \\
\text { weak coarse granular; consistence, soft. }\end{array}$ \\
\hline
\end{tabular}

TABLE 11.-Soil-profile sections-Continued Soil profile section $16 \mathrm{~S}-$ Continued Depth
(inches) $\quad \begin{gathered}\text { Thickness } \\ \text { (inches) }\end{gathered} \quad \begin{gathered}\text { Soil } \\ \text { horizon }\end{gathered}$

15-22 7 C Light-brownish-gray (10YR 6/2) sand; structure, nearly single-grain; consistence, nearly loose.

22-40 $\quad 18 \quad \mathrm{C} \quad$ Light-brownish-gray (10YR 6/2) sand; structure, single-grain; consistence, loose.

1 At this locality the B (oxide) horizon has been somewhat eroded, for its thickness ranges from 0 to 5 inches within a few feet; consequently, the A (vesicular) horizon in this profile probably is of post-Toyeh age. This age also is suggested by the vesicular structure which is abnormally weak for th is soil-compare soll profile section $32 \mathrm{~S}$.

\section{Analyses of physical and chemical properties}

[Sampling and analyses by M. E. Springer, University of California, Berkeley]

\begin{tabular}{|c|c|c|c|c|c|c|}
\hline Horizon & $\begin{array}{c}\text { Depth } \\
\text { (inches) }\end{array}$ & $\begin{array}{c}\text { Apparent } \\
\text { density } \\
\text { (g/cc) }\end{array}$ & $\begin{array}{l}\text { Percent } \\
<2 \text { mm }\end{array}$ & $\mathrm{pH}$ & $\begin{array}{c}\text { Percent } \\
\text { nitrogen } \\
\text { (whole } \\
\text { soil) }\end{array}$ & $\begin{array}{l}\mathrm{CO}_{2} \text { from } \\
\text { carbonates } \\
\text { (whole soil) }\end{array}$ \\
\hline$A$ & $0-3$ & 1.57 & 94.4 & 9.9 & 0.009 & 5. 2 \\
\hline $\mathrm{B}$ and $\mathrm{Cca}$ & 4-11 & 1. 38 & 98.5 & 10.0 & .008 & 2.9 \\
\hline Cca............. & $11-15$ & 1.52 & 98.6 & 10.1 & .004 & 1. 6 \\
\hline C...... & $15-22$ & 1.51 & 96.9 & 10.1 & .003 & 1. 1 \\
\hline C & $22-40$ & 1.47 & 92.4 & 9.9 & .001 & .9 \\
\hline
\end{tabular}

Soil profile section $17 \mathrm{~S}$

Type locality of Harmon School soil. Location: 2/3 mile north of old Harmon schoolhouse; exposed in banks of branch irrigation canal about 150 feet east of county road bridge across main irrigation canal, SW1/4 NW1/4 sec. 24, T. 19 N., R. 29 E. Topographic position: plain. Slope: none. Erosion: none. Exposure: vertical channel dug into canal bank. Altitude: about 3,932 feet. Parent material: colluvium of upper tongue of Indian Lakes formation, derived from clay of Sehoo formation. Overlying material: Harmon School soil is buried beneath about 11 inches of silt, fine sand, and basal tufa of upper member of Sehoo formation, in which the stronger Toyeh soil has developed. The Cca horizon of the Toyeh soil extends down into and somewhat modifies the Harmon School soil. Precipitation: 5 inches per year. Natural cover: Sarcobatus vermiculatus, some shadscale (Atriplex confertifolia). Past and present use: none.

\begin{tabular}{|c|c|c|c|}
\hline $\begin{array}{c}\text { Depth } \\
\text { (inches) }\end{array}$ & $\begin{array}{l}\text { Thickness } \\
\text { (inches) }\end{array}$ & Soil horizon & Description \\
\hline $0-3.5$ & 3.5 & A & $\begin{array}{l}\text { Light-gray clay loam; structure, vesicular, grad- } \\
\text { ing to granular in lower part; consistence, } \\
\text { harsh to floury. } \\
\text { Abrupt boundary. }\end{array}$ \\
\hline $3.5-8$ & 4. 5 & $B_{2} \ldots \ldots$ & $\begin{array}{l}\text { Light-brown loam; structure, weakly columnar } \\
\text { to granular; consistence, hard (dry), brittle. } \\
\text { Gradual boundary }\end{array}$ \\
\hline $8-11$ & 3 & $\mathrm{~B}_{3}-\mathrm{C}_{\mathrm{ea}} \ldots \ldots$ & $\begin{array}{l}\text { Light-brown loam; structure, weakly columnar; } \\
\text { contains abundant hard tufa masses and some } \\
\text { soft calcium carbonate concretions; consist- } \\
\text { ence, hard (dry), brittle. } \\
\text { Clear boundary. }\end{array}$ \\
\hline $11-12 \pm$ & $1 \pm$ & $\begin{array}{l}\text { Cea (Toyeh soil) and } \\
\text { B (Harmon School } \\
\text { soil). }\end{array}$ & $\begin{array}{l}\text { Light-brown clay loam; structure, weakly colum- } \\
\text { nar to granular; contains some white calcium } \\
\text { carbonate coatings and concentrations; con- } \\
\text { sistence, hard (dry), brittle. Locally absent } \\
\text { (eroded). } \\
\text { Clear boundary. }\end{array}$ \\
\hline $12-20 \pm$ & $8 \pm$ & Cea (both soils) $\ldots$ & $\begin{array}{l}\text { Yellow-gray clay loam; structure, coarse granu- } \\
\text { lar; consistence, moderately hard. Weak to } \\
\text { very weak calcium carbonate coatings and } \\
\text { concentrations. } \\
\text { Diffuse boundary. }\end{array}$ \\
\hline
\end{tabular}

Geologic unit
Toyeh soil (vesicular horizon) ing to granular in lower part; consistence, rsh to floury.

ight-brown loam; structure, weakly columnar

Toyeh soil on silt and fine sand of upper member of Sehoo formation.

Toyeh soil on silt and early lithoid tufa of upper member of Sehoo formation; silt probably wavereworked from $B$ horizon of Harmon School soll.

B horizon of Harmon School soil, developed in colluvium of upper tongue of Indian Lakes formation. Cea horizon of Toyeh soil is superposed.

Cca horizon of Harmon School soil and superposed Cca horizon (lower part) of Toyeh soil, on colluvium of upper tongue of Indian Lakes formation.

Note.-Total thickness of colluvium of upper tongue of the Indian Lakes is about 32 inches. It rests on clay of the Sehoo, which was the source material for the colluvium. 


\section{TABLE 11.-Soil-profile sections-Continued}

Soil profile section $32 \mathrm{~S}$

Relict Toyeh soil on dendritic member of Sehoo formation. Location: about 300 feet east of road on east side of Rainbow Mountain and several hundred feet south of 4,160-foot bench mark, in S $1 / 2$ sec. 17, T. 18 N., R. 31 E. Topographic position: top of lake bar (highest shoreline of the middle Sehoo lake). Slope: 1 percent. Erosion: very slight. Exposure: dug pit. Altitude: about 4,175 feet. Parent material: sand of dendritic member of Sehoo formation. Overlying material: none. Vegetatation: greasewood and shadscale, about 6 feet apart; some Artemesia spinescens.

$\begin{array}{ccc}\begin{array}{c}\text { Depth } \\ \text { (inches) }\end{array} & \begin{array}{c}\text { Thickness } \\ \text { (inches) }\end{array} & \begin{array}{c}\text { Soil } \\ \text { horizon }\end{array} \\ -0.75-0 & 0.75 & \text { Lag } \\ & & \text { gravel }\end{array}$

$0-3$

3

A

$3-7$

4

B

$\begin{array}{lll}7-14 & 7 & \mathrm{C}_{c a}\end{array}$

14-35 $21 \quad$ C

\section{Soil profile section $34 \mathrm{~S}$}

Type locality of Churchill soil (sampled and described by M. E. Springer and R. B. Morrison). Location: east bank of wash gully on west side of Churchill Valley, SE1/4SW1/4 sec. 15, T. 18 N., R. 30 E. Topographic position: steep bank of small mountain wash. Exposure: vertical channel dug into bank. Altitude: 4,190 feet. Parent material: eolian sand of Wyemaha formation. Overlying material: Churchill soil is buried under 15 to $20 \mathrm{ft}$ of sand and gravel of Sehoo and Indian Lakes formations (see table 11, section 34).

$$
\begin{array}{ccc}
\begin{array}{c}
\text { Depth } \\
\text { (inches) }
\end{array} & \begin{array}{c}
\text { Thickness } \\
\text { (inches) }
\end{array} & \begin{array}{c}
\text { Soil } \\
\text { horizon }
\end{array} \\
0-10 & 10 & \mathrm{~B}_{2}
\end{array}
$$

Light brown (7.5YR 6/3 to $10 Y R 6 / 5)$ medium sand with sparse rock fragments; noncalcareous; structure, very coarse angular blocky; consistence, hard.

Clear, smooth boundary.

10-16 $\quad 6 \quad \mathrm{~B}_{3} \quad$ Light-brown $\quad(7.5 Y R 6 / 3)$ medium sand, somewhat calcareous with a few white calcareous concretions; structure, almost massive.

Clear, smooth boundary.

TABLE 11.-Soil-profile sections-Continued Soil profile section $34 \mathrm{~S}-$ Continued

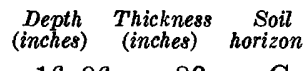

16-96
Description

Very pale brown $(10 Y R 6 / 3$ to $7 / 3)$ medium sand, strongly to somewhat calcareous, with white calcium earbonate streaks, "concretions," and irregular concentrations; structure, structureless, massive to singlegrain; consistence, very hard to loose. Concentration of calcium carbonate decreases somewhat irregularly from top to bottom; upper 2 to $3 \frac{1 / 2}{\mathrm{ft}}$ has numerous to common carbonate streaks and concretions, and is massive and locally almost cemented and hard to very hard; remainder of thickness has some to few calcium carbonate concentrations, is massive to single-grain and slightly hard to loose, except for a $1 / 2$-in. to 1-in. white calcium carbonate cemented layer at 53-54 in depth.

Diffuse boundary.

96-116 20 C Light-gray medium sand (10YR 7/2) with sparse white calcium carbonate streaks and concretions; structure, single-grain; consistence, loose.

Chemical and physical properties

\begin{tabular}{|c|c|c|c|c|c|c|}
\hline Depth (inches) & $\begin{array}{l}\text { Appar- } \\
\text { ent } \\
\text { density } \\
\text { g/cc }\end{array}$ & $\begin{array}{l}\text { Percent } \\
<2 \mathrm{~mm}\end{array}$ & $\mathrm{pH}$ & $\begin{array}{c}\text { Percent } \\
N \text { (whole } \\
\text { soil) }\end{array}$ & $\mathrm{C} / \mathrm{N}$ & $\begin{array}{l}\mathrm{CO}_{2} \text { from } \\
\text { carbonates } \\
\text { (whole } \\
\text { soil) }\end{array}$ \\
\hline $\begin{array}{l}044 \\
4-10 \\
10-16 \\
16-22 \\
22-28 \\
28-40 \\
40-54 \\
54-66 \\
66-84 \\
84-96 \\
96-116\end{array}$ & $\begin{array}{l}1.69 \\
1.50 \\
1.45 \\
1.47 \\
1.53 \\
1.56 \\
1.56 \\
1.49 \\
1.55 \\
1.53\end{array}$ & $\begin{array}{r}98.6 \\
97.8 \\
97.8 \\
96.9 \\
98.3 \\
99.4 \\
99.9 \\
99.8 \\
100.0 \\
100.0\end{array}$ & $\begin{array}{l}8.6 \\
8.6 \\
8.9 \\
8.9 \\
9.1 \\
9.1 \\
8.9 \\
8.8 \\
9.0 \\
9.2\end{array}$ & $\begin{array}{l}0.012 \\
.009 \\
.005 \\
.005 \\
.002 \\
.002 \\
.002 \\
.002 \\
.002 \\
.001\end{array}$ & $\begin{array}{r}9.6 \\
8.7 \\
\hdashline 8.8 \\
\hdashline \\
\hdashline \\
\hdashline \\
\hdashline\end{array}$ & $\begin{array}{l}0.3 \\
1.3 \\
3.8 \\
3.5\end{array}$ \\
\hline
\end{tabular}
[Churchill soil at its type locality. Sampling and analyses by M. E. Springer.

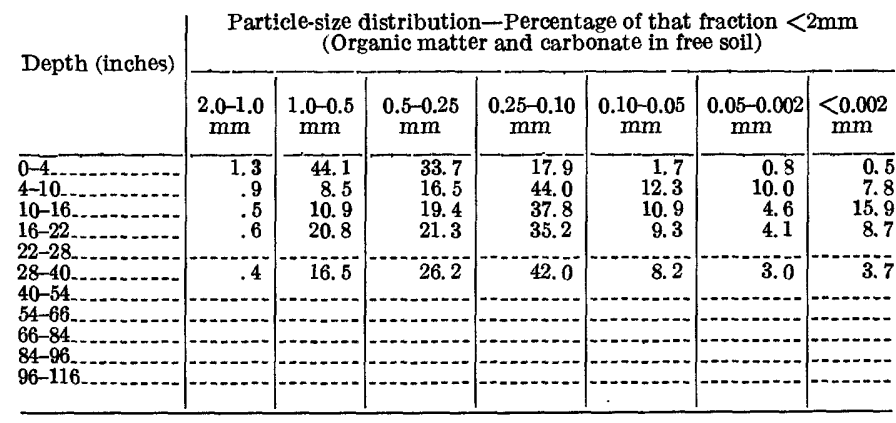

Soil profile section $36 \mathrm{~S}$

Type profile section of the L-Drain soil. Location: northwestern part of Navair Flat, NE1/4 sec. 16, T. 18 N., R. 29 E. Topographic position: nearly level plain. Exposure: dug pit. Erosion: none. Altitude. $3,939 \pm 3$ feet. Parent material: alluvial sand coeval with first lake unit of Fallon formation. 
TABLE 11.-Soil-profile sections-Continued

Soil profile section $36 \mathrm{~S}-$ Continued

Overlying material: $1 \frac{1}{2}$ inches of eolian sand of upper member of Fallon formation.

Depth
(inches) $\begin{aligned} & \text { Thickness } \\ & \text { (inches) }\end{aligned} \quad \begin{gathered}\text { Soil } \\ \text { horizon }\end{gathered}$

$\begin{array}{lll}0-1 & 1 & \text { A }\end{array}$

Light-gray $(10 Y R \quad 7 / 2)$ sandy loam; structure, weak vesicular; consistence, slightly hard.

1-3 2 A Light-gray (10YR 7/2) sandy loam; structure, very weak vesicular and weak coarse granular; consistence, slightly hard.

Abrupt, smooth boundary.

3-7 $4 \quad$ B $\quad$ Brown $(10 Y R$ 5/3) loamy sand; structure, very weak coarse granular; consistence, slightly hard.

7-13 $6 \quad$ Bca Grayish-brown (10YR 5/2) sand; structure, very weak coarse granular; consistence, very soft; locally slightly calcareous.

Clear, wavy boundary.

13-20 7 C Pale-brown $(10 Y R$ 6/3), coarse and medium sand; single-grain, loose, noncalcareous (parent material).

Chemical and physical properties

[Analyzed by M. E. Springer, University of California, Berkeley]

\begin{tabular}{|c|c|c|c|c|c|c|c|}
\hline $\begin{array}{c}\text { Soll } \\
\text { horizon }\end{array}$ & $\begin{array}{c}\text { Depth } \\
\text { (inches) }\end{array}$ & $\begin{array}{l}\text { Appar- } \\
\text { ent den- } \\
\text { sity } \\
(\mathrm{g} / \mathrm{cc})\end{array}$ & $\begin{array}{l}\text { Percent } \\
<2 \mathrm{~mm}\end{array}$ & $\mathrm{pH}$ & $\begin{array}{c}\text { Percent } \\
\text { N } \\
\text { (whole } \\
\text { (soil) }\end{array}$ & $\mathrm{C} / \mathrm{N}$ & $\begin{array}{l}\mathrm{CO}_{2} \text { from } \\
\text { carbonates } \\
\text { (whole } \\
\text { soil) }\end{array}$ \\
\hline $\begin{array}{l}\mathbf{A} \text { (vesicular) } \\
\text { B (oxide) } \\
\mathbf{B}_{\text {cand }} \\
\text { C }\end{array}$ & $\begin{array}{l}0-1 \\
1-3 \\
3-7 \\
7-13 \\
13\end{array}$ & $\begin{array}{r}1.51 \\
1.46 \\
1.51 \\
1.58 \\
-2\end{array}$ & $\begin{array}{l}91.1 \\
94.9 \\
99.6 \\
95.7 \\
87.5\end{array}$ & $\begin{array}{l}9.6 \\
9.5 \\
9.5 \\
9.6 \\
9.6\end{array}$ & $\begin{array}{l}0.006 \\
.006 \\
.006 \\
.006 \\
.005\end{array}$ & $\begin{array}{r}10.0 \\
8.9 \\
6.9 \\
-\end{array}$ & $\begin{array}{r}0.4 \\
.3 \\
.3 \\
.2 \\
.2\end{array}$ \\
\hline
\end{tabular}

\begin{tabular}{|c|c|c|c|c|c|c|c|}
\hline \multirow{2}{*}{$\begin{array}{c}\text { Soil } \\
\text { horizon }\end{array}$} & \multicolumn{7}{|c|}{$\begin{array}{l}\text { Particle size distribution } \\
\text { Percentage of that fraction }<2 \mathrm{~mm} \text { (soil free of organic matter } \\
\text { and car bonate) }\end{array}$} \\
\hline & $\underset{\mathrm{mm}}{2.0-1.0}$ & $\begin{array}{c}1.0-0.5 \\
\mathrm{~mm}\end{array}$ & $\underset{\mathrm{mm}}{0.5-0.25}$ & $\underset{\mathrm{mm}}{0.25-0.10}$ & $\begin{array}{c}0.10-0.05 \\
\mathrm{~mm}\end{array}$ & $\mid \begin{array}{c}0.05-0.002 \\
\mathrm{~mm}\end{array}$ & $\begin{array}{c}0.002 \\
\mathrm{~mm}\end{array}$ \\
\hline $\begin{array}{l}\text { esicular } \\
\text { oxide) }\end{array}$ & $\begin{array}{l}11.2 \\
13.1 \\
17.6 \\
26.1\end{array}$ & $\begin{array}{r}8.2 \\
18.2 \\
28.4 \\
31.4\end{array}$ & $\begin{array}{r}7.8 \\
10.2 \\
12.0 \\
13.4\end{array}$ & $\begin{array}{l}34.1 \\
26.1 \\
22.7 \\
16.3\end{array}$ & $\begin{array}{r}20.1 \\
16.3 \\
9.2 \\
5.9\end{array}$ & $\begin{array}{l}8.3 \\
6.9 \\
3.6 \\
3.4\end{array}$ & $\begin{array}{r}9.0 \\
6.5 \\
3.5\end{array}$ \\
\hline
\end{tabular}

Soil profile section $46 \mathrm{~S}$

Cocoon soil (sampled and described by M. E. Springer and R. B. Morrison). Location: 12 miles southeast from Fallon, Nev., 1,500 feet south southeast from Eagles House, in NE1/4NW1/4 sec. 24, T. 18 N., R. 30 E. Topographic position: crest of hill (almost flat summit). Exposure: dug pit. Altitude: 4,460 feet. Slope: 1 percent. Erosion: very slight. Parent material: silicified tuffaceous sandstone of Truckee formation, overlain by 1 to 3 feet of creep, solifluction, or residual mantle (colluvium). Natural cover: sparse; mainly little greasewood and shadscale.

(Note: Upper part of B horizon apparently is eroded, and the overlying A horizon probably postdates the Cocoon soil proper.)

$\begin{array}{ccc}\begin{array}{c}\text { Depth } \\ \text { (inches) }\end{array} & \begin{array}{c}\text { Thickness } \\ \text { (inches) }\end{array} & \begin{array}{c}\text { Soil } \\ \text { horizon }\end{array} \\ -0.5-0 & 0.5 \pm & -\end{array}$

Gravel and rock pavement cover-

0-3 $\quad 3 \quad$ A ing 80 percent of surface.

Pinkish-gray $(7.5 Y R \quad 7 / 2)$ very fine sandy loam; structure, strong vesicular, moderate coarse columnar; consistence, slightly hard, harsh, floury.

\section{Table 11.-Soil-profile sections-Continued Soll profile section $46 \mathrm{~S}-$ Continued

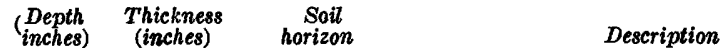

$\begin{array}{ccc}3-8 & 5 & \left(\mathrm{~B}_{3} \mathrm{ca}\right)\end{array}$

Abrupt, smooth boundary; probably minor disconformity.

Reddish-brown (5YR 5/3) stony clay loam, contains some soft calcium carbonate in streaks and blebs; structure, medium granular; consistence, friable.

Clear, wavy boundary.

8-14 $6 \quad \mathrm{Cca}_{1} \quad$ Light-reddish-brown (5YR $\left.6 / 3\right)$ stony loam; contains much soft calcium carbonate; structure, medium to coarse granular; consistence, friable.

Diffuse boundary.

14-20 6 Cca 2 Pink (5YR 7/3) stony loam, with much calcium carbonate structure, massive; consistence, partly cemented by calcium carbonate, very hard.

Gradual boundary.

20-36 $16 \quad \mathrm{Cca}_{2}$

Light-reddish-brown (5YR 6/4) gravelly loam, with less calcium carbonate accumulation than above; structure, structureless, massive; consistence, alternate hard-cemented and loose layers.

Note.-In places calcium carbonate fills cracks of the shattered bedrock to depths of 8-10 feet.

Analyses of physical and chemical properties

[Sampling and analyses by M. R. Springer, University of California, Berkeley,

\begin{tabular}{|c|c|c|c|c|c|c|c|}
\hline Soll horizon & $\begin{array}{l}\text { Depth } \\
\text { (inches) }\end{array}$ & $\begin{array}{l}\text { Appar- } \\
\text { ent } \\
\text { density } \\
(\mathrm{g} / \mathrm{cc})\end{array}$ & $\begin{array}{l}\text { Percent } \\
<2 \mathrm{~mm}\end{array}$ & pH & $\begin{array}{c}\text { Percent } \\
\text { N } \\
\text { (whole } \\
\text { soil) }\end{array}$ & $\mathrm{C} / \mathrm{N}$ & $\begin{array}{c}\mathrm{CO}_{2} \text { from } \\
\text { carbonates } \\
\text { (whole } \\
\text { soil) }\end{array}$ \\
\hline & $\begin{array}{c}0-3 \\
3-8 \\
8-14 \\
14-20 \\
20-36\end{array}$ & $\begin{array}{l}1.34 \\
1.13 \\
1.42 \\
1.38\end{array}$ & $\begin{array}{l}99.5 \\
44.8 \\
33.5 \\
46.2\end{array}$ & $\begin{array}{l}9.3 \\
8.7 \\
8.3 \\
8.3 \\
8.7\end{array}$ & $\begin{array}{r}0.021 \\
.015 \\
.007 \\
.005 \\
.004\end{array}$ & $\begin{array}{r}7.4 \\
9.2 \\
8.7 \\
10.2\end{array}$ & $\begin{array}{r}2.1 \\
3.0 \\
9.0 \\
11.0 \\
16.3\end{array}$ \\
\hline & & 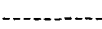 & $\cdots$ & 7.8 & & & \\
\hline
\end{tabular}

Soil profile section $58 \mathrm{~S}$

Cocoon soil (sampled and described by M. E. Springer and R. B. Morrison). Location: summit plateau of White Throne Mountains, 15 miles south of Fallon, Nev., NE $1 / 4 \mathrm{NW}^{1} / 4$ sec. 15, T. 16 N., R. 29 E. ( $1 / 4$ mile southwest of town of Mountains, in Carson Lake quadrangle). Topographic position: broad nearly flat ridge crest. Exposure: dug pit. Altitude: 4,740 feet. Slope: 1 percent. Erosion: very slight to none. Parent material: solifluction and creep mantle about 15 inches thick, underlain by vesicular olivine basalt of Bunejug formation. Natural cover: sparse shrubs (shadscale, 30 percent; little greasewood, 60 percent), very sparse Bromus tectorum.

Depth Thick- ness Soil Description

(inches) (inches) horizon

-1-0 1 $1 \pm$... Desert pavement of dark-brown varnished flaggy basalt blocks and pebbles, covering 90 percent of surface.

0-2 2 A Pinkish-gray $(5 Y R$ 7/2) fine sandy loam; structure, vesicular, moderate coarse columnar and weak medium platy; consistence, slightly hard, harsh. 
TABLE 11.-Soil-profile sections-Continued

Soil profile section 58S-Continued

\begin{tabular}{|c|c|c|c|}
\hline $\begin{array}{c}\text { Depth } \\
\text { (inches) }\end{array}$ & $\begin{array}{c}\text { Thickness } \\
\text { (inches) }\end{array}$ & $\underset{\text { horizon }}{\text { Soil }}$ & Description \\
\hline & & & $\begin{array}{l}\text { Abrupt, smooth boundary; probably minor } \\
\text { disconformity. }\end{array}$ \\
\hline $2-6$ & 4 & $\mathbf{B}_{2}$ & $\begin{array}{l}\text { Reddish-brown }(5 Y R \quad 5 / 3) \text { clay loam; } \\
\text { structure, moderate coarse granular; } \\
\text { consistence, hard. Contains more roots } \\
\text { than layers above and below. } \\
\text { Clear irregular boundary. }\end{array}$ \\
\hline $6-9$ & 3 & $\mathrm{~B}_{3} \mathrm{Ca}$ & $\begin{array}{l}\text { Light-reddish-brown (5YR 6/3) sandy } \\
\text { loam; structure, weak granular; consist- } \\
\text { ence, slightly hard. A few roots; many } \\
\text { calcium carbonate concretions below } 7 \\
\text { in. depth. } \\
\text { Gradual boundary. }\end{array}$ \\
\hline $9-15$ & 6 & Cea & $\begin{array}{l}\text { Pink (5YR 7/3) to white gravelly sandy } \\
\text { loam; contains many flat calcium car- } \\
\text { bonate concretions; structure, massive; } \\
\text { consistence, cemented, very hard. } \\
\text { Gradual boundary. }\end{array}$ \\
\hline $15+$ & --- & Cea & White calcium carbonate cementing frac- \\
\hline
\end{tabular}

Note.-Interval from -1 to 0 and 0 to 2 inches probably has formed later than the Cocoon soil proper and hence is not properly a part of its profile.

\section{Chemical and physical properties}

[Proflle sampled and analyzed by M E. Springer, University of California, Berkeley]

\begin{tabular}{|c|c|c|c|c|c|c|c|c|c|c|}
\hline Soll horizon & $\begin{array}{r}\text { Depth } \\
\text { (inches) }\end{array}$ & $\begin{array}{r}\text { App } \\
\text { ent d } \\
\text { sity }\end{array}$ & & $\begin{array}{l}\text { Per } \\
<2\end{array}$ & & pH & $\begin{array}{l}\text { Percent } \\
N \text { (whole } \\
\text { soil) }\end{array}$ & $\mathrm{C} / \mathrm{N}$ & $\begin{array}{c}\text { C } \\
\text { car } \\
(\text { wh }\end{array}$ & $\begin{array}{l}D_{2} \text { from } \\
\text { bonates } \\
\text { ole soil) }\end{array}$ \\
\hline $\begin{array}{l}\mathrm{A} \\
\mathrm{B}_{2} \\
\mathrm{Bca} \\
\mathrm{Cca}\end{array}$ & $\begin{array}{c}0-2 \\
2-6 \\
6-9 \\
9-15 \\
15+\end{array}$ & \multicolumn{2}{|c|}{$\begin{array}{l}1.33 \\
1.04 \\
1.35 \\
1.47\end{array}$} & \multicolumn{2}{|c|}{$\begin{array}{r}97.2 \\
99.8 \\
57.2 \\
21.5 \\
.8\end{array}$} & $\begin{array}{l}9.3 \\
7.6 \\
8.4 \\
8.5\end{array}$ & $\begin{array}{r}0.017 \\
.047 \\
.026 \\
.014\end{array}$ & $\begin{array}{r}8.3 \\
12.5 \\
10.4 \\
\hdashline \\
\hdashline\end{array}$ & \multicolumn{2}{|r|}{$\begin{array}{r}1.4 \\
13 . \\
23 . \\
20 .\end{array}$} \\
\hline \multirow{2}{*}{ Soll horizon } & \multicolumn{10}{|c|}{$\begin{array}{c}\text { Particle-size distribution } \\
\text { Percentage of that fraction }<2 \mathrm{~mm} \text { (organic matter and carbonate- } \\
\text { free soil) }\end{array}$} \\
\hline & $\underset{\mathrm{mm}}{2.0-1.0}$ & $\begin{array}{c}1,0-0.5 \\
\mathrm{~mm}\end{array}$ & & $\begin{array}{l}-0.25 \\
\mathrm{~nm}\end{array}$ & $\begin{array}{r}0.25 \\
n\end{array}$ & $\begin{array}{l}5-0.10 \\
n m\end{array}$ & $\begin{array}{c}0.10-0.05 \\
\mathrm{~mm}\end{array}$ & $\begin{array}{r}0.05-0 \\
\mathrm{mI}\end{array}$ & $i^{.002}$ & $\underset{\mathrm{mm}}{<.002}$ \\
\hline $\begin{array}{l}\mathrm{A} \\
\mathrm{B}_{\mathbf{2}} \\
\mathrm{Bca} \\
\mathrm{Cca}\end{array}$ & $\begin{array}{l}0.5 \\
.3 \\
1.1 \\
2.6\end{array}$ & $\begin{array}{r}0.3 \\
.4 \\
3.3 \\
2.0\end{array}$ & & $\begin{array}{r}0.6 \\
.6 \\
4.5 \\
3.6\end{array}$ & & $\begin{array}{l}18.6 \\
14.1 \\
26.0 \\
25.7\end{array}$ & $\begin{array}{l}26.7 \\
19.8 \\
24.5 \\
23.4\end{array}$ & & $\begin{array}{l}39.2 \\
21.5 \\
28.1 \\
22.7\end{array}$ & $\begin{array}{l}14.1 \\
43.3 \\
12.5 \\
20.0\end{array}$ \\
\hline
\end{tabular}

Soil profile section $59 \mathrm{~S}$

Cocoon soil showing especially well preserved upper part of profile (sampled and described by M. E. Springer and R. B. Morrison). Location: top of White Throne Mountains, 15 miles south of Fallon, Nev. On line between secs. 15 and 16, T. $16 \mathrm{~N}$., R. 29 E., at south margin of Carson Lake quadrangle. Topographic position: crest of ridge. Exposure: dug pit. Altitude: 4,860 feet. Slope: \pm 1 percent. Erosion: very slight to none. Parent material: colluvium (solifluction and creep mantle) about $1 \frac{1}{2}$ feet thick, underlain by olivine basalt of Bunejug formation. Present climate: average mean annual precipitation about 6 inches; average mean annual temperature about $49^{\circ} \mathrm{F}$. Natural cover: sparse, covers less than three-fourths of surface; mainly shadscale (Atriplex confertifolia), little greasewood (Sarcobatus baileyi), but sage (Artemesia spinescens), and rarely other shrub species, together with sparse grasses (mostly Bromus tectorum) and forbs. Most of bare part of surface covered by desert pavement of slabby blocks and pebbles of basalt, only one stone thick; generally oriented parallel with the surface. Top surfaces of stones are mostly shiny dark brown, dark reddish brown, to nearly black due to desert varnish, whereas under surfaces are dull brownish gray or gray.

$\begin{array}{ccc}\begin{array}{c}\text { Depth } \\ \text { (inches) }\end{array} & \begin{array}{c}\text { Thickness } \\ \text { (inches) }\end{array} & \begin{array}{c}\text { Soil } \\ \text { horizon }\end{array} \\ \end{array}$

Top 2士 -..- Desert pavement of dark-brown-varnished, flaggy blocks and pebbles of basalt, covering 90 percent of surface.

0-2.5 2.5 A Pinkish-gray $(7.5 Y R \quad 7 / 2)$ very fine sandy loam; structure, vesicular (numerous spherical or tubular voids $1 / 4$ to $3 \mathrm{~mm}$ in diameter), moderate coarse columnar and weak medium platy; consistence, slightly hard, harsh, floury. Cracked vertically to form polygonal blocks $2 \frac{1}{2}-4$ in. diameter.

Abrupt smooth boundary.

2. 5-7 4. 5 B $\mathrm{B}_{2} \quad$ Reddish-brown (5YR 5/4) clay loam; structure, moderate medium granular to nuciform (upper $1 / 4 \mathrm{in}$. is finegranular); consistence, slightly hard.

Clear, irregular boundary.

7-10 $\quad 3 \quad$ B $_{3}$ ca $\quad$ Light-reddish-brown $\quad\left(\begin{array}{lll}5 Y R & 6 / 4)\end{array}\right)$ clay loam; structure, moderate medium granular to nuciform; consistence, slightly hard. Some calcium carbonate concretions.

Clear, wavy boundary.

10-14 4 Cea Pink (5YR 7/3) to white gravelly sandy loam, strong' calcium carbonate cementation; structure, weak coarse granular to subangular blocky; consistence, very hard.

Gradual boundary.

14-19 5 Cea Pink (5YR 8/3) to white stony sandy loam, some calcium carbonate cementation; structure, weak coarse granular to subangular blocky; consistence, very hard.

Gradual boundary.

19-60 $41 \quad$ Cea Fractured basalt, cemented with calcium carbonate (soil lime).

NoTE.-Interval from 0 to 2.5 inches is probably younger than the Cocoon soil and hence not properly a part of its profile.

Chemical and physical properities

[Sampled and analyzed by M. E. Springer, University of Califfornia, Berkeley]

\begin{tabular}{|c|c|c|c|c|c|c|c|}
\hline Soil horizon & $\begin{array}{c}\text { Depth } \\
\text { (inches) }\end{array}$ & $\begin{array}{c}\text { Appar- } \\
\text { ent } \\
\text { density } \\
\text { (g/cc) }\end{array}$ & $\begin{array}{l}\text { Percent } \\
<2 \text { mm }\end{array}$ & pH & $\begin{array}{c}\text { Percent } \\
N \\
\text { (whole } \\
\text { soil) }\end{array}$ & $\mathrm{C} / \mathrm{N}$ & $\begin{array}{c}\mathrm{CO}_{2} \text { from } \\
\text { carbon- } \\
\text { ates } \\
\text { (whole } \\
\text { soil) }\end{array}$ \\
\hline $\begin{array}{l}\mathrm{A} \\
\mathrm{B}_{2} \\
\mathrm{~B}_{3} \mathrm{ca} \\
\mathrm{Cca}\end{array}$ & $\begin{array}{cc}0 & -2.5 \\
2.5-7 \\
7 & -10 \\
10 & -14 \\
14 & -19 \\
19 & -36 \\
36 & -60\end{array}$ & $\begin{array}{r}1.52 \\
1.03 \\
1.12 \\
1.56 \\
\end{array}$ & $\begin{array}{l}99.1 \\
93.3 \\
50.3 \\
47.8 \\
15.4 \\
22.3\end{array}$ & $\begin{array}{l}9.0 \\
6.4 \\
7.3 \\
8.7 \\
8.6 \\
8.5\end{array}$ & $\begin{array}{r}0.012 \\
.026 \\
.014 \\
.011 \\
.004 \\
.005\end{array}$ & $\begin{array}{r}9.7 \\
12.6 \\
11.0 \\
10.0 \\
\hdashline-. \\
\hdashline-. .\end{array}$ & $\begin{array}{r}0.7 \\
.1 \\
.8 \\
4.4 \\
9.7 \\
5.2 \\
3.8\end{array}$ \\
\hline
\end{tabular}


TABLE 11.-Soil-profile sections-Continued

Soil profile section 59S-Continued

Chemical and physical properties-Continued

\begin{tabular}{|c|c|c|c|c|c|c|c|}
\hline \multirow{2}{*}{ Soil horizon } & \multicolumn{7}{|c|}{$\begin{array}{c}\text { Particle-size distribution } \\
\text { Percentage of that fraction }<2 \mathrm{~mm} \text { (organic matter and } \\
\text { carbonate-free soil) }\end{array}$} \\
\hline & $\begin{array}{c}2.0-1.0 \\
\mathrm{~mm}\end{array}$ & $\begin{array}{c}1.0-0.5 \\
\mathrm{~mm}\end{array}$ & $\begin{array}{c}0.5-0.25 \\
\mathrm{~mm}\end{array}$ & $\underset{\mathrm{mm}}{0.25-0.10}$ & $\underset{\mathrm{mm}}{0.10-0.05}$ & $\begin{array}{c}0.05-0.002 \\
\mathrm{~mm}\end{array}$ & $\underset{\mathrm{mm}}{<.002}$ \\
\hline $\begin{array}{l}\mathbf{A} \\
\mathbf{B}_{2} \\
\mathbf{B}_{3} \mathrm{ca}_{\ldots} \\
\text { Cca. }\end{array}$ & $\begin{array}{r}0.5 \\
.5 \\
5.5 \\
4.4\end{array}$ & $\begin{array}{r}0.5 \\
.6 \\
4.8 \\
9.0\end{array}$ & $\begin{array}{r}0.7 \\
1.0 \\
4.7 \\
8.7\end{array}$ & $\begin{array}{l}22.8 \\
14.9 \\
26.2 \\
36.0\end{array}$ & $\begin{array}{l}26.7 \\
20.0 \\
21.8 \\
23.0\end{array}$ & $\begin{array}{l}35.9 \\
22.7 \\
22.9 \\
15.6\end{array}$ & $\begin{array}{r}12.9 \\
40.3 \\
14.1 \\
3.3\end{array}$ \\
\hline & 7.2 & 8.3 & 10.0 & 30.9 & 20.3 & 15.9 & $\begin{array}{l}0.0 \\
7.4\end{array}$ \\
\hline
\end{tabular}

TABLE 12.-Logs of wells in the southern Carson Desert area

[Well-Iog numbers are consecutive with numbers of stratigraphic sections and soilprofile sections in tables 11 and 12] Well $\log 14 \mathrm{~L}$

$N W^{1 / 4 S W 1 / 4}$ sec. $17, T .19 N ., R .29$ E. Carson River flood plain; altitude about \$,950 feet. Driller's log of water well; owner, Warren Whitehead; driller, J. B. Reynolds. Well completed March 9, 1949.

Fallon forr. ation:

Soil and silt

Sand

Thickness
$($ feet $)$$\quad \begin{gathered}\text { Depth } \\ \text { (feet) }\end{gathered}$

hoo formation:

Clay

Wyemaha formation:

Sand, hard water

Clay, blue

Sand, blue water-bearing, foul-smelling -..

Clay, gray, tough

Sand, clean, brown

\section{Well $\log 15 \mathrm{~L}$}

$N W_{1 / 4}^{1 / 2 W 1 / 4}$ sec. 24, T. 19 N., R. 27 E. Terrace of Carson River, altitude 4,012 93 feet. Driller's log of well on Ken Ogden ranch. Drilled in 1944.

Indian Lakes formation:

Sand, water-bearing in lower $4 \mathrm{ft} . . . .$. $\begin{array}{cc}\text { Thickness } & \text { Depth } \\ (\text { feet }) & \text { (feet) }\end{array}$

Sehoo formation, dendritic and lower members: Clay . . . . . . . . . . . . . . .

Indian Lakes formation, middle tongue(?): Sand........... 5

Sehoo formation, lower member:

Clay

Sand

Clay

Gravel, sandy

Pea gravel, sandy

Sand, black

Clay _... . -

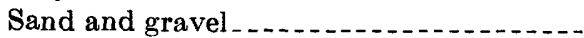

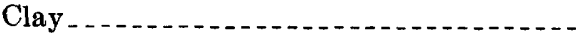

Sand and gravel.

Sand and clay, interbedded.

$\begin{array}{rr}18 & 18 \\ 14 & 32 \\ & \\ 5 & 37 \\ & \\ 5 & 42 \\ & \\ 12 & 54 \\ 4 & 58 \\ 7 & 65 \\ 5 & 70 \\ 12 & 82 \\ 4 & 86 \\ 7 & 93 \\ 1 & 94 \\ 6 & 100 \\ 8 & 108\end{array}$

Well $\log 19 \mathrm{~L}$

$S E^{1 / 4} S W 1 / 4$ sec. 30, T. 19 N., R. 29 E. Carson River flood plain, altitude about 3,960 feet. Driller's log of water well drilled

\section{TABLE 12.-Logs of wells-Continued}

Well log 19L-Continued

in 1948; owner, City of Fallon; driller, John Champion. Main source of water for Fallon.

Fallon formation:

Surface soil

Sand, fine

Sand and gravel, water-bearing

Wyemaha formation:

Clay, sandy

Sand, fine, and soft clay

Clay, hard, blue...... 1

Sand, fine and soft clay

"Tule" sand, fine, (with dark-colored organic matter), very bad odor..........

Sand, coarse, and gravel; bad-smelling water . . . .

"Tule" sand, very fine

Sand, coarse, and gravel; "tule" (swamp) water . . . . .

Clay, brown

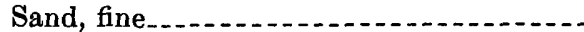

Sand, fine, and gravel, water-bearing .....

Clay, brown..............................

Sand, fine..................................

Clay, brown .............................

Clay, brown, sandy

"Tule" (organic) clay, black, soft........

"Tule" (organic) clay, brown, soft, sandy.-

Sand, coarse, and gravel......

Clay hard, black

Unit unknown:

Clay, fine-sandy, and mud......... $\quad 138 \quad 308$

Clay, soft, brown $\ldots \ldots \ldots \ldots \ldots \ldots$

Sand, fine, clay and mud. . .

Clay, light, sandy .................... $\quad 2 \quad 332$

Clay, hard, brown

Clay, gray

Clay, soft, and mud. $56 \quad 392$

Sand............................... $63 \quad 455$

Probably basalt of Rattlesnake Hill or Bunejug formation:

Basalt, hard, black

Lava, porous............... 2460

Lava, porous, slightly harder._....... $\quad 15 \quad 475$

Lava, porous

Lava, very hard

\section{Well $\log 20 \mathrm{~L}$}

NW1/4 sec. 35, T. 19 N., R. 27 E.; altitude $3995 \pm 5$ feet. 1904 water test borehole, No. 46 in Herman Stabler (written communication, 1904) report, water level 11 feet below surface in 1904.

Wyemaha formation:

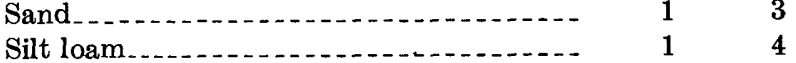

"Alkali hardpan"... 5

Sand

Sand, coarse.

Gravel

Well $\log 21 \mathrm{~L}$

SE1/4NE1/4 sec. 39, T. 19 N., R. 28 E.; Carson River flood plain, altitude 3,982 2 feet. Driller's log of water well; driller, George 
TABLE 12.-Logs of wells-Continued

Well log 21L-Continued

F. Shuey, Fallon, Nev. Drilled in 1944. Had to seal off lower part of well; using water from pea gravel at 98-100 feet.

Fallon and Wyemaha formations:

Sand

Wyemaha formation:

$\begin{array}{lrr}\text { Clay } & 4 & 26 \\ \text { Sand with streaks of clay, aquifer. } & 34 & 60 \\ \text { Sand, black } & 5 & 70 \\ \text { Clay } & 75 \\ \text { Sand with streaks of clay, aquifer } & 5 & 93 \\ \text { Pea gravel, good aquifer } & 2 & 100 \\ \text { Clay } & 3 & 103 \\ \text { Gravel } & 2 & 105 \\ \text { Sayd, black, with sulfur water } & 2 & 107 \\ \end{array}$

Well $\log 27 \mathrm{~L}$

SW1/4SE1/4 sec. 4, T. 18 N., R. 28 E.; altitude about $3,980 \pm$ feet. Driller's log of water well; owner, Ben A. Pflum; driller, Mel Meyer. Well completed August 18, 1949.

Fallon formation:

Topsoi

Wyemaha formation(?):

Clay, orange......

Wyemaha formation:

Clay, black (swamp deposit) Thickness Depth
(feet) 22

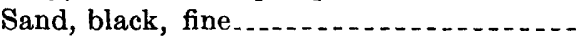

Sand, green-gray

Sand, gray

Sand, coarse.

Clay, black ...........

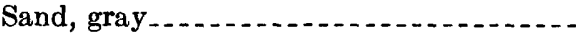

Sand, fine, blue, water-bearing............

Sand, fine, gray, water-bearing-.........

Sand, fine, gray, water-bearing

Clay, green, sandy . . . . . . . . . . .

Sand, fine, gray, water-bearing -.........

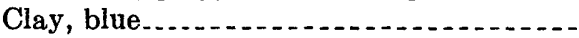

Sand, black and white, water bearing-...-

Sand, black, fine, water-bearing ...........

Sand, gray, coarse and fine, water-bearing-

$\begin{array}{rr}\begin{array}{c}\text { Thickness } \\ (\text { feet }) \\ 10\end{array} & \begin{array}{r}\text { Depth } \\ (\text { feet }) \\ 10\end{array} \\ & \\ 5 & 15 \\ & \\ 30 & 45 \\ 5 & 50 \\ 5 & 55 \\ 5 & 60 \\ 5 & 65 \\ 2 & 67 \\ 8 & 75 \\ 5 & 80 \\ 3 & 83 \\ 7 & 90 \\ 18 & 108 \\ 2 & 110 \\ 4 & 114 \\ 11 & 125 \\ 22 & 147 \\ 18 & 165 \\ 10 & 175\end{array}$

Well $\log 38 \mathrm{~L}$

SW1/4 sec. 23, T. 18 N., R. 29 E. U.S. Naval Auxiliary Air Station. Altitude, about 3,925 feet. Driller's log of test well for water; owner, U.S. Dept. of Navy. Well completed February 1944.

Fallon formation:

Sand

$\begin{array}{cc}\text { Thickness } & \text { Depth } \\ (\text { feet }) & \text { (feet) }\end{array}$

o formation:

Clay, gray

Wyemaha formation:

Clay, black ....

Correlation uncertain:

Clay, gray

Clay, soft, black

Clay, gray -

Clay, gray, and fine sand ................

Clay, black . . . . . . . .

Clay, greenish-gray

Clay, gray-green
TABLE 12.-Logs of wells-Continued

\section{Well log 38L-Continued}

Correlation uncertain-Continued

Clay, gray . . . .

Clay, green .....

Clay, gray - ......

Clay, green-gray

Clay, gray, and streaks of sand.........

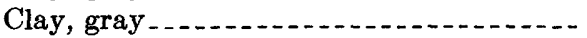

Clay, gray, and sandy grit............

Clay, gray - . . . . .

Sand, fine

Clay, gray - .

Clay, sandy, gray ..............

Clay, gray -

Clay, sandy, gray

Clay, gray -

Sandstone. . . . . .

Clay, gray ............

Clay, soft, gray

Clay, hard, gray, and sand............

Clay, soft, gray............................

Clay, gray

Clay, gray, some sand streaks

Clay, grimy, green.

$\begin{array}{rr}\begin{array}{c}\text { hickness } \\ (\text {,eet })\end{array} & \begin{array}{r}\text { Depth } \\ (\text { feet })\end{array} \\ 155 & 755 \\ 25 & 780 \\ 80 & 860 \\ 26 & 886 \\ 76 & 962 \\ 94 & 1,056 \\ 24 & 1,080 \\ 176 & 1,256 \\ 2 & 1,258 \\ 52 & 1,310 \\ 17 & 1,327 \\ 3 & 1,330 \\ 32 & 1,362 \\ 27 & 1,389 \\ 1 & 1,390 \\ 27 & 1,417 \\ 9 & 1,426 \\ 2 & 1,428 \\ 12 & 1,440 \\ 4 & 1,444 \\ 28 & 1,472\end{array}$
what appeared to be fine-grained waterlaid tuff from bottom of well.

Well $\log 51 \mathrm{~L}$

$S E_{1 / 4}^{1 / 4} W_{1 / 4}^{1 / 4 e c . ~ 18, ~ T . ~} 17$ N., R. 29 E. Plain northeast of Carson Lake; Jones and Jewell ranch; altitude 3,918 5 feet. Driller's log of test well for oil and gas drilled August 1, 1921 to October 1923, for Syndicate Oil Co. (also known as Miller-Syndicate Oil Co. and Syndicate Oil and Gas Co.). Reported total depth either 3,132 or 3,\$00 feet (Richards, 1947); rotary rig used to 3,036 feet; churndrilled below. Well already abandoned when visited in 1947.

Fallon formation:

Surface......

Sehoo formation:

Clay, sticky, yellow

$\begin{array}{cc}\begin{array}{c}\text { Thickness } \\ \text { (feet) }\end{array} & \begin{array}{c}\text { Depth } \\ \text { (feet) }\end{array} \\ 20 & 20\end{array}$

Wyemaha formation:

Sand and gravel $\ldots \ldots$

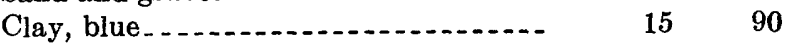

Gravel ......................... $25 \quad 115$

Gumbo, black, gas showing . . .

Gumbo, black...................... $64 \quad 194$

Correlation uncertain:

Shale(?) _.

Gumbo and sand .............. $\quad 54 \quad 250$

Sand

Sand, hard ......... 338

Shale, soft, gray

Sand, fine.... $20 \quad 368$

Sand, coarse ........... $13 \quad 381$

Shale, hard, sandy

Sand, hard ........... $34 \quad 431$

Sand, fine............... $10 \quad 441$

Sand, hard

Crevice...... 446

Sand, fine

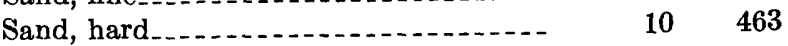

Shale, rotten (smelling?), black; turns gray on exposure to air............ 
TABLE 12.-Logs of wells-Continued Well $\log 51 \mathrm{~L}-$ Continued

Correlation uncertain-Continued

Sand, fine

Sand, very hard; small crevices and thick hard "shells"

Sand, fine

Shale, sandy, gray

Sand, hard, some shale . . . . . . . . .

Shale, gray

Shale, sandy, gas showing at $544 \mathrm{ft} . . .-$

Shale, gray; crevice.................

Shale, sand streaks.......................

Shale, sandy -

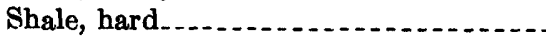

Clay, tough, blue. ........

Sand.

Shale, hard. .

Clay, tough, blue.

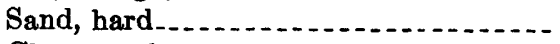

Clay, tough, blue.

Clay ................

Sand, very hard .....

Shale, very hard.........

Clay and shale.

Sand and shale

Shale, sandy......

Shale, gray _.....

Shale, sandy ......

Sand, coarse ......

Shale, sandy . . .

Shale, blue..........

Sand, coarse, water at $725 \mathrm{ft}$. . . . . . .

Sand, hard.

Shale, hard .................

Shale, gray, and sand. . . .

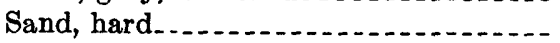

Shale with sand streaks

Shale

Shale, sandy

Shale

Sand.

Shale, hard . . . . .

Shale, soft ........

Sand, coarse, hard..........

Shale, sandy . . . . . . .

Shale

Shale, hard. . . . . .

Sand, hard

Clay, sticky

Sand, fine

Shale, tough, gray . .

Shale, tough, gray, with sand streaks...

Shale, tough, gray ...................

Sand, fine

Sand, hard, and clay

Sand, fine; and shale................

Shale with sand streaks..............

Shale, sandy

Shale-

Sand hand

Shale-

Sand, hard.........

Shale.

\begin{tabular}{|c|c|}
\hline $\begin{array}{c}\text { Thickness } \\
\begin{array}{c}(\text { feet }) \\
7\end{array}\end{array}$ & $\begin{array}{l}\text { Depth } \\
\text { (feet) } \\
480\end{array}$ \\
\hline 8 & 488 \\
\hline 12 & 500 \\
\hline 11 & 511 \\
\hline 17 & 526 \\
\hline 6 & 532 \\
\hline 14 & 546 \\
\hline 9 & 555 \\
\hline 10 & 565 \\
\hline 5 & 570 \\
\hline 13 & 583 \\
\hline 8 & 591 \\
\hline 6 & 597 \\
\hline 21 & 618 \\
\hline 5 & 623 \\
\hline 14 & 637 \\
\hline 6 & 643 \\
\hline 7 & 650 \\
\hline 2 & 652 \\
\hline 0.7 & 652.7 \\
\hline 15. 3 & 668 \\
\hline 3 & 671 \\
\hline 13 & 684 \\
\hline 7 & 691 \\
\hline 12 & 703 \\
\hline 3 & 706 \\
\hline 6 & 712 \\
\hline 9 & 721 \\
\hline 5 & 726 \\
\hline 4 & 730 \\
\hline 9 & 739 \\
\hline 9 & 748 \\
\hline 7 & 755 \\
\hline 8 & 763 \\
\hline 9 & 772 \\
\hline 6 & 778 \\
\hline 12 & 790 \\
\hline 7 & 797 \\
\hline 1 & 798 \\
\hline 6 & 804 \\
\hline 10 & 814 \\
\hline 8 & 822 \\
\hline 7 & 829 \\
\hline 1 & 830 \\
\hline 7 & 837 \\
\hline 13 & 850 \\
\hline 10 & 860 \\
\hline 42 & 902 \\
\hline 20 & 922 \\
\hline 8 & 930 \\
\hline 12 & 942 \\
\hline 17 & 959 \\
\hline 20 & 979 \\
\hline 25 & 1,004 \\
\hline 19 & 1,023 \\
\hline 34 & 1,057 \\
\hline 5 & 1,062 \\
\hline 12 & 1,074 \\
\hline 6 & 1,080 \\
\hline 17 & 1,097 \\
\hline
\end{tabular}

TABLE 12.-Logs of wells-Continued Well $\log 51 \mathrm{~L}-$ Continued

Correlation uncertain-Continued

Shale, hard...

Shale ..........

Sand, hard............

Shale, sandy . . .

Sand, coarse . . .

Sand, hard.

Shale, sandy - .

Sand, hard

Shale, hard . . . . . .

Shale, hard, sandy, slow drilling ......-

Shale, hard ...........................

Shale and streaks of hard sand.......

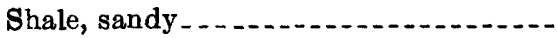

Shale, sandy, gray

Shale ..........

Limestone shale, hard.

Shale, sandy .........

Limestone shale, hard..........

Shale, blue, with limestone streaks....-

Sand. . .

Limestone shale. . . . . . . . . . . .

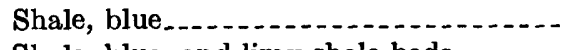

Shale, blue, and limy shale beds......-

Shale, blue...

Sand, hard...

Rock.

"Quartz".

Conglomerate (?), very hard

Conglomerate (?), extremely

"Lime," blue, with thin shale streaks; very hard; gas showing ...........

Shale, soft, blue. . . . .

Shale, hard.

Shale, blue.

Shale, hard

Shale, blue.

Sand.

Shale, hard.

Shale and sand, strong gas showing - - -

Shale

Shale and sand.

Shale, gray.

Rock

Shale and "oil" sand.

Shale

Sand, hard.

Sand and shale

Sand, hard, and shale

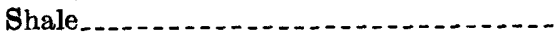

Shale, very hard.

Sand and shale

Rock

Shale

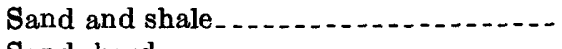

Sand, hard.

Shale.

Sand ..... - 2.

Sand, hard

Sand and shale; crevice, lost circulation.

Shale.

\begin{tabular}{|c|c|}
\hline $\begin{array}{c}\text { hickness } \\
(\text { feet })\end{array}$ & $\begin{array}{l}\text { Depth } \\
\text { (feet) }\end{array}$ \\
\hline 7 & 1,104 \\
\hline 10 & 1,114 \\
\hline 13 & 1,127 \\
\hline 7 & 1,134 \\
\hline 21 & 1,155 \\
\hline 3 & 1,158 \\
\hline 42 & 1,200 \\
\hline 3 & 1,203 \\
\hline 1 & 1,204 \\
\hline 4 & 1,208 \\
\hline 2 & 1,210 \\
\hline 9 & 1,219 \\
\hline 3 & 1,222 \\
\hline 28 & 1,250 \\
\hline 16 & 1,266 \\
\hline .5 & 1,266 . \\
\hline 9.5 & 1,276 \\
\hline 1 & 1,277 \\
\hline 11 & 1,288 \\
\hline 2 & 1,290 \\
\hline 2 & 1,292 \\
\hline 16 & 1,308 \\
\hline 54 & 1,362 \\
\hline 4 & 1,366 \\
\hline 2 & 1,368 \\
\hline 1 & 1,369 \\
\hline 5 & 1,374 \\
\hline 3 & 1,377 \\
\hline 4 & 1,381 \\
\hline 1 & 1,382 \\
\hline 59 & 1,441 \\
\hline 5 & 1,446 \\
\hline 4 & 1,450 \\
\hline 7 & 1,457 \\
\hline 3 & 1,460 \\
\hline 3 & 1,463 \\
\hline 7 & 1,470 \\
\hline 4 & 1,474 \\
\hline 8 & 1,482 \\
\hline 4 & 1,486 \\
\hline 18 & 1, 504 \\
\hline 14 & 1,518 \\
\hline .5 & $1,518$. \\
\hline 1. 5 & 1,520 \\
\hline 28 & 1,548 \\
\hline 4 & 1,552 \\
\hline 13 & 1,565 \\
\hline 22 & 1,587 \\
\hline 31 & 1,618 \\
\hline 8 & 1,626 \\
\hline 36 & 1,662 \\
\hline 5 & 1,667 \\
\hline 11 & 1,678 \\
\hline 12 & 1,690 \\
\hline 5 & 1,695 \\
\hline 25 & 1,720 \\
\hline 11 & 1,731 \\
\hline 2 & 1,733 \\
\hline 21 & 1,754 \\
\hline 26 & 1,780 \\
\hline
\end{tabular}


TABLE 12.-Logs of wells-Continued

Well $\log 51 \mathrm{~L}-$ Continued

Correlation uncertain-Continued

Shale, hard, gas showing

Sand, shaly; crevice, lost circulation

Shale.

Shale, hard, sandy

Shale, lost circulation . . . . . . . .

Shale, soft, blue

Shale, sticky, gooey

Sand, fine.

Shale, gray ..... . . . . . .

Sand, hard.

Shale, gray

Sand, hard

Shale

Sand and shale

Shale, hard.

Sand and shale.

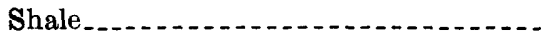

Sand, hard.

Shale.

Sand, hard.

Shale...-

Shale, brown ........

Sand, hard.

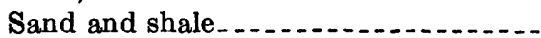

Sand, running . . .

Shale.

Sand, hard........

Shale

Sand, hard, and shale $\ldots . . . . . . .$.

Quicksand......

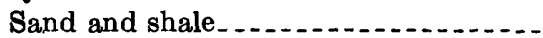

Lime, blue ............

Shale, sticky, blue................

Sand and shale.........

Shale, sticky, blue

Sand, hard

Lime, white ........

Sand, hard.

Shale, sticky

Clay, sticky _........

Shale, nonsandy . . . .

Shale, sticky _...

Shale and sand. ......................

Sand.

Shale, sticky _. . .

Sand, fine.

Shale, hard .

Shale.

Sand, hard

Sand, fine, gas showing

Shale.

$\begin{array}{rr}\begin{array}{r}\text { Thickness } \\ (\text { feet })\end{array} & \text { Depth } \\ (\text { feet }) \\ 1 & 1,781 \\ 13 & 1,794 \\ 4 & 1,798 \\ 1 & 1,799 \\ 4 & 1,803 \\ 33 & 1,836 \\ 24 & 1,860 \\ 5 & 1,865 \\ 14 & 1,879 \\ 2 & 1,881 \\ 35 & 1,916 \\ 5 & 1,921 \\ 17 & 1,938 \\ 32 & 1,970 \\ 4 & 1,974 \\ 21 & 1,995 \\ 35 & 2,030 \\ 5 & 2,035 \\ 25 & 2,060 \\ 6 & 2,066 \\ 20 & 2,086 \\ 14 & 2,090 \\ 6 & 2,096 \\ 24 & 2,120 \\ 14 & 2,134 \\ 19 & 2,153 \\ 7 & 2,160 \\ 32 & 2,192 \\ 20 & 2,212 \\ 16 & 2,228 \\ 30 & 2,258 \\ 2 & 2,260 \\ 12 & 2,272 \\ 22 & 2,294 \\ 44 & 2,338 \\ 3 & 2,341 \\ 6.5 & 2,347.5 \\ 3.5 & 2,351 \\ 43 & 2,394 \\ 15 & 2,409 \\ 10 & 2,419 \\ 12 & 2,431 \\ 73 & 2,504 \\ 40 & 2,544 \\ 60 & 2,604 \\ 16 & 2,620 \\ 16 & 2,636 \\ 48 & 2,684 \\ 14 & 2,698 \\ 11 & 2,709 \\ 26 & 2,735\end{array}$

NorE.-D. F. Hewett, of the U.S. Geological Survey, visited this well in May 1922 when it was 2,845 feet deep. He reported (U.S. Geol. Survey open-file report 1922): water level stood 300 feet below surface, gas bubbled up from outside the casing and was under slight pressure in casing cuttings were "largely greenish shaly clay, probably derived from finely divided water laid tuff, and no volcanic fow or breccia material was recognized. Cuttings contained minute shells, which in field were considered to be gastropods and bivalves. Specimens were submitted to the National Museum, but the only fossils found were simple ostracods considered to be derived from fresh water Tertiary rocks." R. W. Richards (U.S. Geol. Survey open-file report, 1947) mentioned that various items in the Churchill County Eagle between June 10, 1922, and October 1923 stated that the well reached 3,036 feet with rotary equipment, then was deepened either 96

\section{TABLE 12.-Logs of wells-Continued \\ Well $\log 52 \mathrm{~L}$}

$N 1 / 2 S E 1 / 4$ sec. $13, T .17$ N., R. 28 E. Former bed of Carson Lake; altitude, 3,920 feet. Driller's log of water well; well owner, George Dalton; driller, George Norcutt.

Fallon formation:

Topsoil

$\begin{array}{cr}\text { Thickness } & \text { Depth } \\ \text { (feet }) & \begin{array}{c}\text { (feet) } \\ 8\end{array} \\ 2 & 8 \\ 2 & 10\end{array}$

Sand

$2 \quad 10$

Sehoo formation:

Clay, yellow .

Wyemaha formation:

Sludge, black

Clay, blue............... 64

Sludge, black ..................... $23 \quad 109$

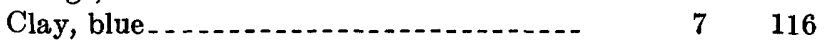

Sludge, black .............

Clay, blue. . . . .

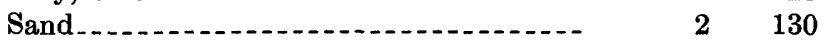

Clay, yellow . . .

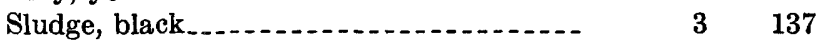

Clay, blue............ $31 \quad 168$

Sludge, black ..................... 3171

Clay, blue.............. $13 \quad 184$

Sludge, black

Clay, blue .............

Sludge, black

Clay, yellow _.

Sludge, black

Correlation uncertain:

Clay, blue..... 6220

Sand

Clay, blue...................... $18 \quad 240$

Clay, yellow

Clay, blue...... $71 \quad 321$

Sand, water.................. $49 \quad 370$

Clay, blue. . .

Limestone, white................... 24423

Clay, blue....... $17 \quad 440$

Sand

Clay, blue. $\ldots . \ldots 48$

or possibly 264 feet by cable-tool, between September 1922 and October 1923. In'June 1922, 61/4-inch casing was set at 2,590 feet; later this casing was pulled and 4-inch casing was run to 3,035 feet and 3 inch to 3,128 feet; 70 feet of hard sandstone with 'oil and gas showing" is reported below about 2,875 feet, and below 3,128 feet, very hard sandstone, with drilling rates from 1 to 3 feet a day, and a "strong gas show" between 3,147 and 3,152 feet. Richards reported, however, that C. D. Murray, who did most of the cable-tool drilling, recollected in 1946 that most of the section was soft shale.

\section{FOSSIL-MOLLUSK LOCALITIES}

Symbols in parentheses, following the locality numbers, are field-locality designations. Mollusk species, determined by J. E. P. Morrison, U.S. Geological Survey, are listed in table 7.

F-1. (N2-80.) Lithoid tufa of Eetza formation, containing snail shells. Float fragment in eolian sand of Wyemaha formation, at boundary between oxide and calcareous horizons of Churchill soil. East bank of west gully in Churchill Valley, 1,000 feet west of Sehoo Mountain, SW1/4 sec. 15 , T. 18 N., R. 30 E. ; altitude $4,190 \pm 20$ feet.

F-7. (N3-109, H-17). Gastropods in granule-sand, beneath cellular tufa-cemented pebble gravel. Lower member of 
Sehoo formation, probably transgressive phase. Southeast edge of White Throne Mountains, altitude about 4,275 feet. SE $1 / 4$ sec. 16 , T. 16 N., R. 29 E.

F-8. (N3-110, H-12). Gastropods from 25-foot bed of silt, below 6 feet of cobble gravel. Transgressive phase, lower member of Sehoo formation. Northern White Throne Mountains, altitude 4,230 feet, $\mathrm{SE}^{1} / 4 \mathrm{NE} 1 / 4$ sec. 9 , T. $16 \mathrm{~N}$., R. $29 \mathrm{E}$.

F-9. (N3-41, H-5). Gastropods from lower part of 20-foot deposit of marly silt. Lower member of Sehoo formation, probably transgressive phase. Northwestern White Throne Mountains, altitude 4,190 feet, $\mathrm{SE}^{1 / 4} \mathrm{NW} 1 / 4$ sec. 11, T. $16 \mathrm{E}$., R. $29 \mathrm{E}$.

F-10, (UC-L). Gastropods in fine pebble gravel, 6 feet below basal guano layer. Lower member of Sehoo formation. Leonard rock shelter archaeologic site, 11 miles due south from Lovelock, Nev., on northwest piedmont of West Humboldt Range, altitude about 4,175 feet.

F-11. (N3-99, H-3). Gastropods in yellow marly silt, transgressive phase, lower member of Sehoo formation. Southeastern White Throne Mountains, altitude 4,320 feet. $\mathrm{SE} 1 / 4 \mathrm{NE} 1 / 4$ sec. 15 , T. 16 N., R. $29 \mathrm{E}$.

F-12. (N3-98, H-4). Snails in sandy gravel, 20 feet stratigraphically below cellular tufa-cemented cobble gravel. Transgressive phase, lower member of Sehoo formation. Northern White Throne Mountains, altitude 4,290 feet. NW $1 / 4$ sec. 10 , T. 16 N., R. 29 E.

F-13. (N2-80, 210B). Gastropods in sand, interstitial in and overlying boulder gravel, 3.2 to 5.2 feet below surface. Transgressive phase, lower member of Sehoo formation. Dug pit, south side of hill west of Sehoo Mountain, altitude 4,200 feet. NW $1 / 4 \mathrm{NW}^{1 / 4}$ sec. 22 , T. 18 N., R. $30 \mathrm{E}$.

F-14. (N2-80, 210D). Gastropods in cellular tufa at same site; about 2 feet above F-13. Transgressive phase, lower member of Sehoo formation.

F-15. (N2-73, R-1a). Gastropods, in sand 6 feet stratigraphically below and at same site as F-16. Transgressive phase, lower member of Sehoo formation.

F-16. (N2-73, R-1b). Gastropods in 3-foot granule-sand bed, overlain by 3 feet of pebble gravel at top of bay bar, same site as F-15. Regressive phase, lower member of Sehoo formation. Saddle between Sehoo Mountain and Eagles. House, altitude 4,330 feet. NE $1 / 4$ sec. 23 , T. 18 N., R. 30 E.

F-17. (N2-80, C-2). Gastropods, in pebbly sand of lower member of Sehoo formation (probably regressive phase). Same site as locality F-1, except about 20 feet stratigraphically higher, altitude 4,210 feet.

F-18. (N7-10, R-2). Gastropods in pebbly sand. Regressive phase of lower member of Sehoo formation, overlying cellular tufa-cemented gravel of this member. One-quarter mile southeast from 4,398-foot summit, Bunejug Mountains ; sec. 22 (unsurveyed), T. 17 N., R. 30 E., altitude 4,200 \pm 20 feet.

F-19. (N2-81, R-x4). Gastropods in sandy fine gravel. Re gressive phase of lower member of Sehoo formation. Beach terrace embankment on west side of Sehoo Mountain, altitude 4,325 feet. $\mathrm{NW}^{1 / 4} \mathrm{NW}^{1 / 4}$ sec. 15 , T. $18 \mathrm{~N}$., R. $30 \mathrm{E}$.

F-20. (N2-116, 194). Gastropods in sand. Regressive phase of lower member of Sehoo formation. Tiny spit at northeast edge of Eetza Mountain, altitude 4,090 fee:. SE1/4 SE1/4 sec. 21 , T. 18 N., R. 30 E.
F-21. (N3-99, H-2). Gastropods from perlite sand overlying yellow marly silt, at same site as F-11. Lower member of Sehoo formation, probably regressive phase.

F-22. (N2-80, 210F). Gastropods in silt and fine sand overlying cellular tufa, 1 to $2 \frac{1}{2}$ feet below surface, same site as F-13. Probably regressive phase, lower member of Sehoo formation.

F-23. (N7-106, P-1). Gastropods from gravel of lower member of Sehoo formation. East front, Cocoon Mountains, 0.65 mile south-southwest from northeast corner of Allen Springs quadrangle; altitude about 425 feet.

F-24. (N8-30, R-7b). Gastropods, in sand 3 to 6 feet below top of stratigraphic section $\mathbf{5 5}$. Lower member of Sehoo formation, probably regressive phase. Northeast side, Cocoon Mountains; altitude 4,320 feet; 0.2 mile northwest from 4,645-foot summit.

F-26. (N2-124, P-4). Gastropods from sand of upper member of Sehoo formation. Northeast side, Bass Flats, altitude 3,960 feet. $\mathrm{NW} 1 / 4$ sec. 4 (unsurveyed), T. $16 \mathrm{~N}$., R. $30 \mathrm{E}$.

F-29. (N3-14, R-x5). Snails from lake sand of first lake unit of Fallon formation. SE $1 / 4 \mathrm{SW}^{1 / 4}$ sec. 24 , T. 19 N., R. 29 E. ; altitude 3,929 feet.

F-30. (N3-123, R-x1). Gastropods from lacustrine sandy silt, 3 to $7 \frac{1}{2}$ feet beneath surface, of first lake unit of Fallon formation. Drainage-canal exposure 2 miles southeast of Fallon, altitude 3,945 feet; $\mathrm{SE}_{1 / 4}^{1 / \mathrm{NE}^{1} / 4}$ sec. 4, T. $18 \mathrm{~N}$., R. $29 \mathrm{E}$.

F-31. (N3-129, R-1). Snail and clam shells from lake sand of first lake unit of Fallon formation, 1/4 mile west of Carson River and 6 miles north of Fallon; altitude 3,945 feet; NE $1 / 4$ SE $1 / 4$ sec. 33 , T. 20 N., R. $29 \mathrm{E}$.

F-32. (N1-248R, R-1). Gastropods from Lacustrine clayey silt and silty sand, $41 / 2$ to 5 feet below surface. Probably first or second lake unit of Fallon formation. Borehole on crest of low ridge, northwest side of Stillwater Lakes, altitude 3,880 feet; NW1/4, sec. 22, T. 21 N., R. 31 E.

F-33. (N3-82, R-2). Snails and clams in distributary-channel sand and lake sand (at surface) of second lake unit of Fallon formation, 6 miles northeast of Fallon, altitude 3,920 to 3,930 feet; SW cor., sec. 2 , T. 19 N., R. 29 E.

F-34. (N2-128, R-3b). Snails and clams from flne gravel (bar deposit), second lake unit of Fallon formation. Wildcat scarp east of Carson Lake, altitude 3,927 feet. $\mathrm{SE} 1 / 4 \mathrm{SW}^{1} / 4$ sec. 29, T. 17 N.. R. $30 \mathrm{E}$.

F-35. (N2-135, R-x1). Gastropods and pelecypods from sand of second lake unit of Fallon formation. West side Turupah Flat, altitude 3,930 feet; $\mathrm{NE}^{1 / 4} \mathrm{NW}^{1 / 4}$ sec. 32 , T. $18 \mathrm{~N}$., R. $30 \mathrm{E}$.

F-36. (N2-174, R-1). Snails in sand of second lake unit of Fallon formation, 1 mile south of U.S. Highway 50 at Grimes Point, altitude 3,927 feet; NE $1 / 4$ NE $1 / 4$ sec. 31 , T. 18 N., R. $30 \mathrm{E}$.

F-37. (N2-137, P-1). Snails and clams from sand of second lake unit of Fallon formation, 400 feet up L-Drain Canal from junction with Diagonal Drain; altitude 3,925 feet. NE $1 / 4$ NE $1 / 4$ sec. 17 , T. 18 N., R. 30 E.

F-38. (N3-144, B-1). Snails from sand of third lake unit of Fallon formation, 1 mile west of Wolf Dam, altitude 3,915 feet. NE1/4 NE1/4 sec. 20 , T. 20 N., R. 29 E.

F-39. (N3-12, R-4). Snails from sand of third lake unit of Fallon formation. SE1/4 sec. 12, T. 19 N., R. 29 E., altitude 3,910 feet. 
F-40. (N3-12, R-1). Gastropods from sand of third lake unit of Fallon formation. SW $1 / 4$ sec. 12, T. 19 N., R. 29 E., altitude 3,908 feet.

F-41. (N3-57, R-2). Gastropods from sand of third lake unit of Fallon formation. $\mathrm{SE} 1 / 4 \mathrm{SE} 1 / 4$ sec. 11, T. $19 \mathrm{~N}$., R. 29 E. ; altitude 3,913 feet.

F-42. (N2-174, R-2). Gastropods and pelecypods from sand of third lake unit of Fallon formation. East side Carson Lake, altitude 3,920 feet. NW $1 / 4$ NE $1 / 4$ sec. 31 , T. $18 \mathrm{~N}$., R. $30 \mathrm{E}$.

F-43. (N2-128, R-2). Clam and snail shells from fine pebble gravel (beach-terrace deposit) of third lake unit of Fallon formation. East side Carson Lake, altitude 3,920 feet. $\mathrm{SE}^{1} / 4 \mathrm{SW} 1 / 4$ sec. 29, T. 17 N., R. $30 \mathrm{E}$.

F-45. (N1-205R, R-1). Gastropods in lake sand of young lake and interlake unit of Fallon formation, $1 \%$ miles southeast of Canvasback Gun Club, altitude 3,895 feet. SW $1 / 4$ SW $1 / 4$ sec. 34, T. 20 N., R. $31 \mathrm{E}$.

F-46. (N1-200, B-1). Snails in lake sand of young lake and interlake unit of Fallon formation $1 / 3$ mile south of Carson Sink, altitude 3,880 feet. NW1/4 sec. 17, T. 21 N., R. $31 \mathrm{E}$.

F-47. (N1-200, B-6). Snails from surface lake sand of young lake and interlake unit of Fallon formation, 1 mile south of Carson Sink, altitude 3,878 feet. $\mathrm{NW}^{1 / 4} \mathrm{NE}^{1 / 4}$ sec. 20 , T. 21 N., R. $31 \mathrm{E}$.

F-48. (GS2-156, B-12). Gastropods from lake sand of young lake and interlake unit of Fallon formation, $1 / 2$ mile south of Leter Ranch, altitude 3,880 feet. $S W 1 / 4 \mathrm{SE}_{1 / 4}$ sec. 24 , T. 21 N., R. 29 E.

F-49. (N1-206R, R-1B). Snail and clam shells from lacustrine sandy clay of young lake and interlake unit of Fallon formation; exposed in canal bank, 1 foot below surface, $1 \frac{1}{3}$ miles southeast of Canvasback Gun Club, altitude 3,890 feet. SE $1 / 4$ NW $1 / 4$ sec. 34 , T. 20 N., R. 31 E.

F-50. (N2-95, R-1). Snails (associated with nodules of lithoid tufa) in lake sand of young lake and interlake unit of Fallon formation, 1 mile east of Little Cottonwood Lake, altitude 3,887 feet. $\mathrm{SE}^{1 / 4} \mathrm{SE} 1 / 4$ sec. 10 , T. 20 N., R. $31 \mathrm{E}$.

F-51. (N2-93, R-1). Snail and clam shells from lake sand of young lake and interlake unit of Fallon formation, 2 miles south of Big Cottonwood Lake, altitude 3,895 feet. NW1/4 NW $1 / 4$ sec. 27 , T. 20 N., R. 30 E.
F-52. (N3-93, H-1). Snails from lake sand of young lake and interlake unit of Fallon formation; from surface of small island in northern embayment of Carson Lake, altitude 3,909 feet. NE $1 / 4$ sec. 10, T. 17 N., R. 29 E.

F-53. (11-17-no. 1). Mussel shells from surface lake silt, young lake and interlake unit of Fallon formation. Near south edge of Carson Lake, altitude 3,909 feet. NW1/4NE1/4 sec. 5, T. 16 N., R. 29 E.

F-54. (N1-196, R-1). Clam and snail sheils from lake sand and silt of young lake and interlake unit of Fallon formation, 1 mile northwest of Millens Channel, west of Stillwater Lakes; altitude, 3,875 feet. $\mathrm{SE} 1 / 4 \mathrm{NW}^{1 / 4}$ sec. 5, T. 20 N., R. 31 E.

F-55. (N3-66, B-1). Gastropods and pelecypods from lake sand of young lake and interlake unit of Fallon formation, 11/2 miles southwest of Leter Ranch; altitude, 3,880 feet. SW $1 / 4$ sec. 23 , T. 21 N., R. 29 E.

F-56. (N3-73, B-3). Gastropods from lake sand of young lake and interlake unit of Fallon formation, 2 miles west of Leter Ranch, altitude 3,880 feet. $\mathrm{NE}_{1 / 4} \mathrm{SE}_{1 / 4}$ sec. 22 , T. 21 N., $\mathbf{R}$. $29 \mathrm{E}$.

F-57. (GS2-83, no. 3). Gastropods from lake sand of young lake and interlake unit of Fallon formation, 2 miles south of Carson Sink, altitude 3,885 feet. SW1/4 SW1/4 sec. 24, T. 21 N., R. $30 \mathrm{E}$.

F-58. (N3-68, B-2). Clam from lake sand of young lake and interlake unit of Fallon formation. South edge of Carson Sink, altitude 3,875 feet. NW1/4 SW1/4 sec. 11, T. 21 N., $R$. $29 \mathrm{E}$.

F-59. (N1-200, B-7). Snails from lake sand of young lake and interlake unit of Fallon formation, 1 mile south of Carson Sink, altitude 3,870 feet. NE $1 / 4$ NE $1 / 4$ sec. 20 , T. 21 N., R. $31 \mathrm{E}$.

F-60. (Ch. Nar.) Snails from surface of marshy meadow, floor of Churchill Narrows, $1 / 4$ mile from north end, near Wabuska, Nev. (Present-day forms.)

F-61. (N3-152, 234). Present-day snails from mud in bottom of drainage canal, 11/4 miles east of Fallon. NE1/4 $\mathrm{SE}^{1 / 4} \mathrm{sec}$. 32, T. 19 N., R. 29 E.

F-62. (Reg. Res.). Present-day mussel shells from shore of S-Line Regulating Reservoir, 11/2 miles east of Rattlesnake Hill. NW $1 / 4$ sec. 22 , T. 19 N., R. 29 E. 



\section{INDEX}

[Italic page numbers indicate major references]

\section{A}

Acknowledgments.
Agriculture
Alluvial gravel and colluvium of Eetza age.
Alluvial gravel, Paiute formation
Analyses of natural gas........
Anters, Ernst, conclusions on Lake Lahontan..
$\quad$ estimates of Lake Lahontan age
Aquifers....
Archaeology.

Archaeology 102,105

\section{B}

Basalt of Rainbow Mountai

Basalt of Rattlesnake Hill.

sal Hogback

Bedrock floor, configuration

Bentonite

Borax...

Bunejug formation, deposition general features

Buena Vista Valley

Oalcareous horizon, Churchill soil

Cocoon soil definition.

Calcic Brown soils..........

Canyons.

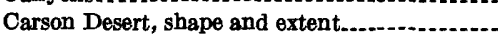

Carson River, alluvial sand and silt

drainage area

entrenchment during thinolite recession....

flood plain

Carson Sink, description

Cellular tufa.

Churchill formation.

Churchill soil, correlation. formation. profile characteristics relations and distribution................... type locality

Climate

Climatic bistory

Cocoon formation. . . . .

Cocoon Mountains, fault pattern

Cocoon soil, age.

correlation.

definition.

(n)

general features and relations

profile characteristics.

Colluvium, Paiute age

Color terms, soils.

Combustion.

Construction materials.

Correlation of Quaternary deposits and soils, means.

D

Dacite of Rainbow Mountain

Deflation basins and plains.

\begin{abstract}
Dendritic Lake
Dendritic tufo

Drainage
\end{abstract}

Earthqnakes.

Economic geography

Economic geology

Eetza formation, correlation with previously described deposits

deposition

genoral features

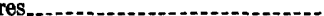

gravel.

lake gravel..

lake sand, silt, and clay

lithology

mollusks.

paleontology.

shore features.

Eetza lake, shorelines

Erosional features, pre-Lake Lahontan

Evaporation

Explosion craters

Fallon formation, alluvium

colluvium.

deposition.

eolian sand

fossils

general fegtt

lake sediments and shore features...........

mollusks....

subdivisions

tufa.

upper and lower members

Fallon lakes, history

Faulting, episodes.

Faults, basin-and-range

pre- and post-Sehoo............................

pre-Truckee.

Quaternary

Tertiary

Field work

k localities

Geographic setting Geologic history.

Glaciation.

Gray Desert soils

Ground water

Guano

H

Harmon School soil . ............................ 19,75

Hidden Cave
Eagles House rhyolite, deposition
Page

springs .-

Humboldt River

Indian inhabitation

Indian Lakes delta

Indian Lakes formation, tongues and age units..- 68 Introdnction.

Irrigation.

J

Jones, J. C., conclusions on Lake Lahontan

$\mathbf{K}$

Knickerbocker andesite

L

L-Drain soil, definition and general features.... 19, 91 formation. . . .................................. 104

Lacustrine sediments, pre-Lake Lahontan...... 23

Lahontan beach................................... 30

Lahontan Valley group, subdivisions............ 28

Lake Bonneville, correlation with.............. 110

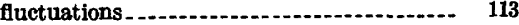

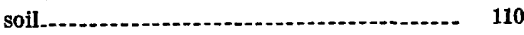

Lake Lahontan, age, from rate of salt accumulation............ 111

fluctuations. . .................................. 113

Lake history, method of analysis............... 18

Lake Provo - ............. 111

Landforms.

Lithoid tnfa.

Location

Lousetown formation ........................... 14

$\mathbf{M}$

Magnetometer traverses......................... 17

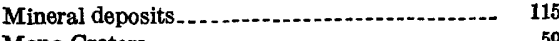

Mono Craters.................................... 59

Mono Lake area, correlation with ............. 110

$\mathbf{N}$

Natural gas and petroleum.

O

Oxide horizon, Churchill soil. ................. 40

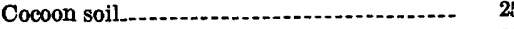

definition 20

$\mathbf{P}$

Paiute formation, deposition................... 98

general features.................................. 23

Pediments........................................ 16, 22

Perlite_....................... 116

Petroleum, occurrence........................... 115

Phytogenic dunes.............................. 85

Population ....................... 8

Pre-Lake Lahontan history 


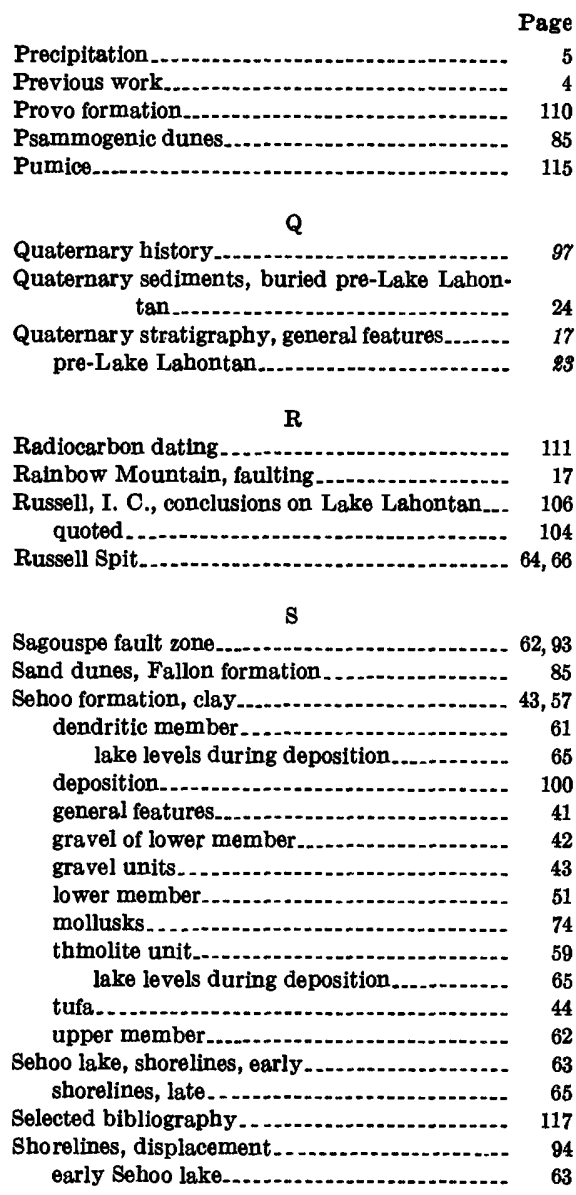

Page

Shorelines-Continued Eetza age late Sehoo lake.

Sierra Nevada, cormelation with

with

Soda Lake, volcanic-sand complex

Soils, classiflcation

definition and general features

descriptive terminology...

Fallon age, general features..................

formation, climate factors.....................

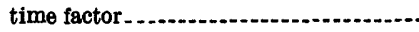

groups.

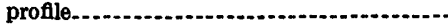

proflle sections. . . ..............................

Sehoo and Indian Lakes age....................

structural and textural terms.

Solonchak and Solonetz soils, variants towand

Springs.

Stillwater Lakes fault zone.

Stillwater Range

Stratigraphic correlation, by position and soil sequences

Stratigraphic sections

ls.

\section{$\mathbf{T}$}

Temperature...

Tertiary history

Tertiary rocks.

Textural terms, soils

Thinolite Lake

Tioga stage

Towns...

Toyeh formation

Toyeh soil, calcareous horizon.................. correlation.

definition and general features..................

formation...

profle characteristics.....................................

stratigraphic relations and occurrence........
Toyeh soil-Continued

variants toward Solonchak and Solonetz soils.

vesicular horizon

Transportation

Truckee formation, deposition................. 96

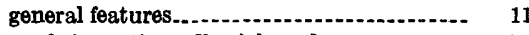

Turupah formation, alluvial sand .............. 77 deposition.................................... 102 eolian sand.................................... 76

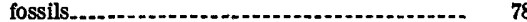
general features................. 75 loess...................... 77

$\mathbf{U}$

Upsal Hogback, eruptions at.

Vegetation.

Vesicular horizon, definition.... 20

W

Waves, during Eetza time....................... $\quad \theta 9$

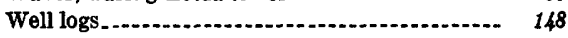
Wells_............................................... 117 White Throne Mountains, marginal faults...... $\quad 16$ Wildcat fault zone............................... 92 Wildcat scarp............. 28, 61, 92 Wind velocity ...................................... 6

Windshadow dunes............................ 85

Wyemaha formation, alluvial and colluvial gravel and sand..................... 36

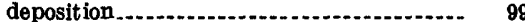

eolian sand................................. 34, 42

general features...................... 34

lake and subaerial sediments................. 36

paleontology............................... 38

subsurface basin sediments.................. 37

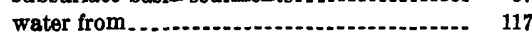




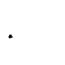


